Supporting Information for:

\title{
C-H and $\mathrm{O}_{2}$ Activation at a $\mathrm{Pt}(\mathrm{II})$ Center Enabled by Novel Sulfonated CNN Pincer Ligand
}

David Watts, Daoyong Wang, Mackenzie Adelberg, Peter Y. Zavalij, Andrei N. Vedernikov*

Department of Chemistry and Biochemistry, University of Maryland, College Park, MD 20742

\section{avederni@umd.edu}

I. Materials and Methods

II. Ligand Synthesis

III. Synthesis of Pt Complexes

IV. Major Species in Solution and Effect of $\mathrm{H}_{2} \mathrm{O}$ and Temperature

V. VT NMR and Van'T Hoff Plots of solutions of $\mathbf{7}$ in TFE

VI. General Procedures for H/D Exchange Reactions

VII. H/D Exchange Reactions

VIII. Oxidation of Complex 7 in TFE Solutions

IX. NMR Spectra

$X$. DFT Calculations

XI. Crystallographic Details

XII. References 


\section{Materials and Methods}

All manipulations were carried out under argon atmosphere unless otherwise noted. All reagents for which the synthesis is not given were purchased from Aldrich, Acros, AlfaAesar, TCl America, or Pressure Chemicals and were used without further purification except where stated. Deuterium labeled solvents were purchased from Cambridge Isotope Laboratories $\left(\mathrm{C}_{6} \mathrm{D}_{6}, \mathrm{CDCl}_{3}, \mathrm{CD}_{3} \mathrm{OD}\right.$, and $\left.\mathrm{DMSO}-\mathrm{d}_{6}\right)$ or Sigma-Aldrich $\left(\mathrm{CF}_{3} \mathrm{CH}_{2} \mathrm{OD}\right) .{ }^{1} \mathrm{H}(400 \mathrm{MHz})$ and ${ }^{13} \mathrm{C}$ NMR $(125 \mathrm{MHz})$ spectra were recorded on a Bruker AVANCE 400 or Bruker DRX-500. Chemical shifts are reported in parts per million (ppm) $(\delta)$ and referenced to residual solvent resonance peaks. Multiplicities are reported as follows: br (broad signal), s (singlet), d (doublet), t (triplet), q (quartet), quin (quintet), sex (sextet), $m$ (multiplet), dd (doublet of doublets), ddd (doublet of doublet of doublets), qd (quartet of doublets). Coupling constants (J) are reported in $\mathrm{Hz}$. High Resolution Mass Spectrometry (HRMS) experiments were performed using a JEOL AccuTOF-CS instrument. 


\section{Ligand Synthesis}

Li(Ph-dpms), lithium (6-phenylpyrid-2-yl)(2-pyridyl)methanesulfonate
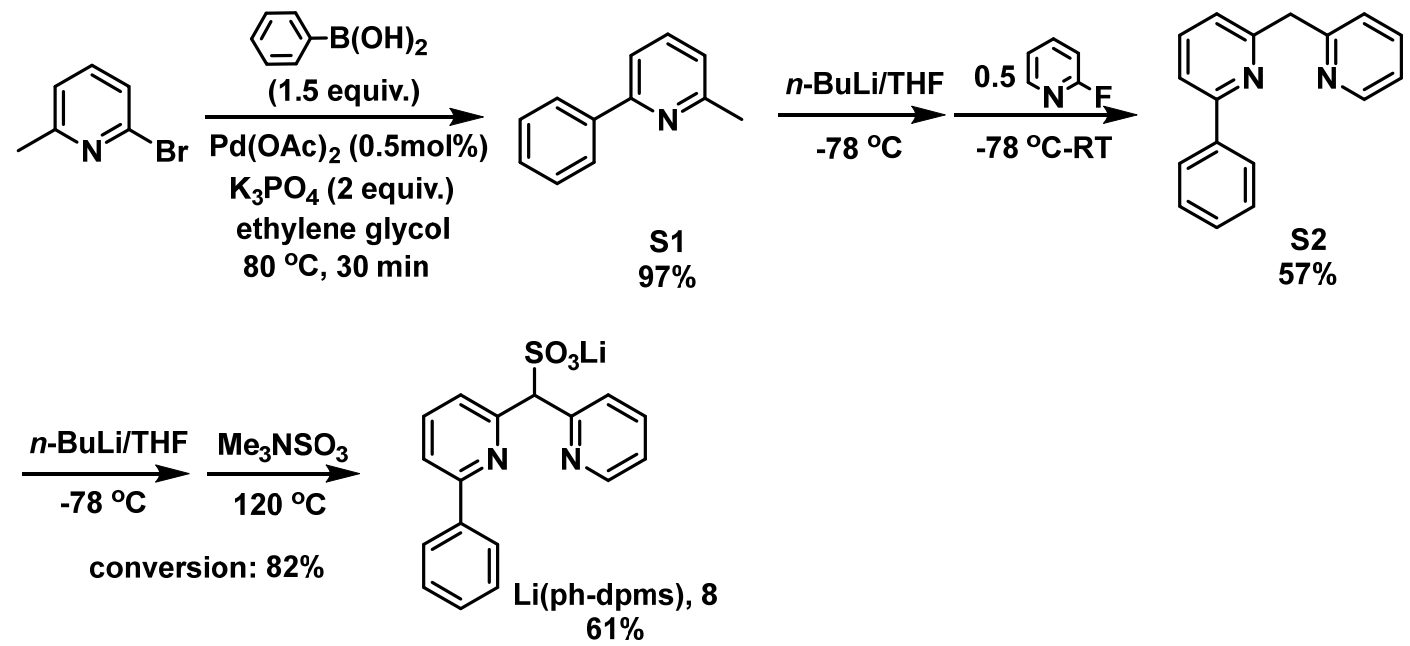

2-phenyl-6-methylpyridine (S1) - 2-phenyl-6-methylpyridine was prepared in $97 \%$ yield starting from 2-bromo-6-methylpyridine and phenylboronic acid according to the literature method. ${ }^{1}$

\section{(6-phenylpyrid-2-yl)(2-pyridyl)methane (S2):}

A solution of 2-phenyl-6-methylpyridine $(1.69 \mathrm{~g}, 10 \mathrm{mmol})$ in $20 \mathrm{~mL}$ of dry THF was cooled to $-78{ }^{\circ} \mathrm{C}$ in a $50 \mathrm{~mL}$ Schlenk flask using a dry ice-acetone bath. $n$-BuLi $(2.5 \mathrm{M}, 4.0 \mathrm{~mL}$, $10 \mathrm{mmol}$ ) was slowly added to the stirred solution, resulting in a color change from light yellow to dark red. After stirring the solution for an additional hour, 2-fluoropyridine (0.58 $\mathrm{g}, 6 \mathrm{mmol}$ ) was added dropwise via syringe. The dry ice bath was subsequently removed and the reaction mixture was allowed to warm to room temperature and stirred overnight. $30 \mathrm{~mL}$ of water was added to quench the reaction. The organic and aqueous layers of the resulting yellow solution were separated, the aqueous layer was extracted with $\mathrm{Et}_{2} \mathrm{O}(3 \mathrm{X}$ $30 \mathrm{~mL}$ ) and the combined organic phase was dried over $\mathrm{MgSO}_{4}$. After filtration, the solvents were removed under reduced pressure, and the residual oil was purified by flash chromatography [silica, hexanes/EtOAc/TEA(1/1/0.01)] to yield $0.70 \mathrm{~g}$ product $(57 \%$ yield based on 2-fluoropyridine used).

${ }^{1} \mathrm{H} \mathrm{NMR}\left(400 \mathrm{MHz}, 22{ }^{\circ} \mathrm{C}, \mathrm{CDCl}_{3}\right), \delta: 4.66(\mathrm{~s}, 2 \mathrm{H}), 7.17\left(\mathrm{ddd},{ }^{3} \mathrm{JHH}_{\mathrm{HH}}=7.6,4.8 \mathrm{~Hz},{ }^{4} \mathrm{JHH}_{\mathrm{HH}}=\right.$ $1.6 \mathrm{~Hz}, 1 \mathrm{H}), 7.44\left(\mathrm{~d},{ }^{3} \mathrm{JHH}_{\mathrm{HH}}=8.0 \mathrm{~Hz}, 1 \mathrm{H}\right), 7.52\left(\mathrm{~d},{ }^{3} \mathrm{~J}_{\mathrm{HH}}=8.0 \mathrm{~Hz}, 1 \mathrm{H}\right), 7.62-7.76(\mathrm{~m}, 4 \mathrm{H})$, $7.79\left(\mathrm{~d},{ }^{3} \mathrm{~J}_{\mathrm{HH}}=8.8 \mathrm{~Hz}, 1 \mathrm{H}\right), 7.91\left(\mathrm{dd},{ }^{3} \mathrm{JHH}_{\mathrm{HH}}=7.2 \mathrm{~Hz},{ }^{4} \mathrm{~J}_{\mathrm{HH}}=2.0 \mathrm{~Hz}, 1 \mathrm{H}\right), 8.60$ (ddd, ${ }^{3} \mathrm{JHH}_{\mathrm{HH}}=$ $\left.4.8,2.0 \mathrm{~Hz},{ }^{4} \mathrm{JHH}_{\mathrm{HH}}=0.8 \mathrm{~Hz}, 1 \mathrm{H}\right), 9.36\left(\mathrm{dd},{ }^{3} \mathrm{JHH}_{\mathrm{HH}}=8.0 \mathrm{~Hz},{ }^{4} \mathrm{~J}_{\mathrm{HH}}=0.6 \mathrm{~Hz}, 1 \mathrm{H}\right)$.

${ }^{13} \mathrm{C}$ NMR (125 MHz, $22{ }^{\circ} \mathrm{C}$, DMSO-d $)$, ס: 47.1, 118.3, 122.0, 122.6, 124.0, 127.0, 129.1, $129.4,137.0,138.1,139.1,149.5,155.9,159.6,159.8$. 
ESI-MS of solution of $\mathbf{S} 2$ in methanol, $[\mathbf{S} 2+\mathrm{H}]^{+}=247.137$. Calculated for $[\mathbf{S} 2+\mathrm{H}]^{+}$ $\mathrm{C}_{17} \mathrm{H}_{15} \mathrm{~N}_{2}, 247.124$.

\section{Li(Ph-dpms), 8}

(6-phenylpyrid-2-yl)(2-pyridyl)methane $(0.70 \mathrm{~g}, 2.8 \mathrm{mmol})$ was mixed with $3 \mathrm{~mL}$ of dry THF in a $25 \mathrm{~mL}$ Schlenk flask under argon. The solution was cooled to $-78{ }^{\circ} \mathrm{C}$ and $2.5 \mathrm{M}$ $n$-BuLi (1.1 mL, $2.8 \mathrm{mmol}$ ) was added dropwise over $10 \mathrm{~min}$ while stirring. The resulting dark red solution was stirred for an additional half hour before being removed from the cold bath and brought into an argon atmosphere glovebox. $\mathrm{NMe}_{3} \cdot \mathrm{SO}_{3}$ complex $(0.39 \mathrm{~g}$, $2.8 \mathrm{mmol}$ ) was added. The Schlenk flask was then closed with a Teflon seal and the mixture was heated in an oil bath for 24 hours at $120^{\circ} \mathrm{C}$ while rapidly stirring. The next day a large amount of precipitate had formed. The mixture was then cooled to $5{ }^{\circ} \mathrm{C}$ and the reaction quenched with $10 \mathrm{~mL}$ deionized water. The product was extracted in water and washed with diethyl ether $(3 \times 10 \mathrm{~mL})$. The water layer was concentrated and the residue was dried under vacuum. The crude product was dissolved in dry trifluoroethanol and filtered through a paper filter to remove inorganic impurities. The filtrate was concentrated and dried. The resulting residue was purified by flash chromatography [silica, EtOAc/ $\mathrm{CH}_{2} \mathrm{Cl}_{2} / \mathrm{MeOH} / \mathrm{Et}_{3} \mathrm{~N}(2 / 2 / 1 / 0.01)$ ]. The eluent was treated with $\mathrm{K}_{2} \mathrm{CO}_{3}$ to convert any triethylammonium salts to TEA and then filtered and dried to yield $0.56 \mathrm{~g}$ product $(61 \%$ yield). The formation of the disulfonated product can be minimized by running the reaction at high concentrations $(\geq 0.5 \mathrm{M})$ which promotes precipitation of the desired monosulfonated product.

${ }^{1} \mathrm{H}$ NMR $\left(400 \mathrm{MHz}, 22{ }^{\circ} \mathrm{C}, \mathrm{MeOD}\right), \delta: 5.80(\mathrm{~s}, 1 \mathrm{H}), 7.34$ (ddd, ${ }^{3} \mathrm{JHH}_{\mathrm{HH}}=7.2,4.8 \mathrm{~Hz},{ }^{4} \mathrm{JHH}_{\mathrm{H}}=$ $0.8 \mathrm{~Hz}, 1 \mathrm{H}), 7.38-7.45(\mathrm{~m}, 3 \mathrm{H}), 7.75\left(\mathrm{dd},{ }^{3} \mathrm{~J}_{\mathrm{HH}}=7.6 \mathrm{~Hz},{ }^{4} \mathrm{~J}_{\mathrm{HH}}=0.8 \mathrm{~Hz}, 1 \mathrm{H}\right), 7.82-7.92(\mathrm{~m}$, $3 \mathrm{H}), 8.00-8.02(\mathrm{~m}, 2 \mathrm{H}), 8.26\left(\mathrm{~d},{ }^{3} \mathrm{JHH}_{\mathrm{HH}}=8.0 \mathrm{~Hz}, 1 \mathrm{H}\right), 8.47\left(\mathrm{dd},{ }^{3} \mathrm{JHH}_{\mathrm{HH}}=4.0 \mathrm{~Hz},{ }^{4} \mathrm{~J}_{\mathrm{HH}}=0.4 \mathrm{~Hz}\right.$, $1 \mathrm{H})$.

${ }^{13} \mathrm{C}$ NMR (125 MHz, $\left.22{ }^{\circ} \mathrm{C}, \mathrm{MeOD}\right), \delta: 73.6,117.3,121.1,121.6,124.0,125.1,126.7$, 127.0, 135.0, 135.5, 137.8, 146.3, 154.0, 154.7, 154.9.

ESI-MS of solution of $\mathrm{Li}(\mathrm{Ph}-\mathrm{dpms})$ in water, $[\mathrm{Ph}-\mathrm{dpms}]^{-}=325.085$. Calculated for $[\mathrm{Ph}-$ dpms]: $\mathrm{C}_{17} \mathrm{H}_{13} \mathrm{~N}_{2} \mathrm{O}_{3} \mathrm{~S}, 325.065$. 


\section{Synthesis of Pt Complexes}

\section{$\underline{\mathrm{K}\left[\left(\mathrm{C}_{6} \mathrm{H}_{4} \text {-dpms }\right) \mathrm{PtCl}\right], 9}$}

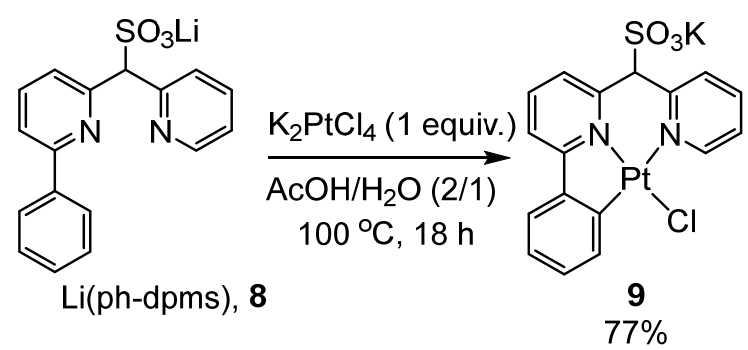

$\mathrm{Li}(\mathrm{Ph}$-dpms) (100 mg, $0.3 \mathrm{mmol})$ and $\mathrm{K}_{2} \mathrm{PtCl}_{4}(125 \mathrm{mg}, 0.3 \mathrm{mmol})$ were dissolved in 4.0 $\mathrm{mL}$ deionized $\mathrm{H}_{2} \mathrm{O}$ and transferred to a $25 \mathrm{~mL}$ Schlenk tube. The red solution was diluted with $8.0 \mathrm{~mL}$ glacial acetic acid and a stir bar was added. The tube was sealed and brought to $100{ }^{\circ} \mathrm{C}$ for 18 hours while stirring. The resulting yellow solution was concentrated and dried under vacuum and the residue was extracted with warm trifluoroethanol $(8 \mathrm{~mL})$. The product was obtained as a 1:1 mixture of 9: $\mathrm{LiCl}$ by removing trifluoroethanol (163 mg, $91 \%$ ), appearing as a yellow solid. This mixture can be used in the preparation of 7 . To remove $\mathrm{LiCl}$, the yellow solid was recrystallized from $\mathrm{H}_{2} \mathrm{O} / \mathrm{EtOH}$. The yellow crystalline powder was filtered off, washed with cold $\mathrm{EtOH}$ and then dried in a vacuum oven at 60

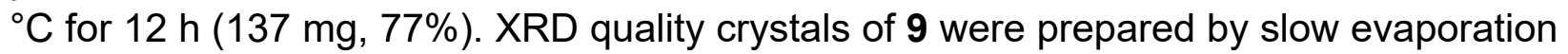
of a saturated methanolic solution.

${ }^{1} \mathrm{H}$ NMR $\left(125 \mathrm{MHz}, 22{ }^{\circ} \mathrm{C}\right.$, DMSO-d6), $\delta: 5.933(\mathrm{~s}, 1 \mathrm{H}), 7.05(\mathrm{~m}, 2 \mathrm{H}), 7.49-7.57(\mathrm{~m}, 2 \mathrm{H})$, $7.61\left(\mathrm{dd},{ }^{3} \mathrm{JHH}_{\mathrm{HH}}=7.1 \mathrm{~Hz},{ }^{4} \mathrm{JHH}_{\mathrm{HH}}=1.9 \mathrm{~Hz}, 1 \mathrm{H}\right), 7.81\left(\mathrm{vd},{ }^{3} \mathrm{JHH}_{\mathrm{HH}}=7.7 \mathrm{~Hz}, 1 \mathrm{H}\right), 7.93\left(\mathrm{vd},{ }^{3} \mathrm{JHH}_{\mathrm{HH}}=\right.$ $7.8 \mathrm{~Hz}, 2 \mathrm{H}), 8.04\left(\mathrm{vt},{ }^{3} \mathrm{~J}_{\mathrm{HH}}=7.98 \mathrm{~Hz}, 1 \mathrm{H}\right), 8.07\left(\mathrm{ddd},{ }^{3} \mathrm{~J}_{\mathrm{HH}}=9.5,7.6 \mathrm{~Hz},{ }^{4} J_{\mathrm{HH}}=1.9 \mathrm{~Hz}\right.$, $1 \mathrm{H}), 9.6\left(\mathrm{dd},{ }^{3} \mathrm{JHH}_{\mathrm{H}}=6.0 \mathrm{~Hz},{ }^{4} \mathrm{JHH}_{\mathrm{HH}}=1.3 \mathrm{~Hz}, 1 \mathrm{H}\right)$.

${ }^{13} \mathrm{C}$ NMR $\left(400 \mathrm{MHz}, 22{ }^{\circ} \mathrm{C}\right.$, DMSO-d $)$, $\delta: 76.6,117.8,123.3,123.7,124.0,126.7,128.5$, 129.6, 135.2, 138.0, 138.1, 143.0, 145.7, 149.8, 152.3, 153.1, 166.8.

ESI-MS of solution of 1 in water, $[1-\mathrm{K}]^{-}=553.973$. Calculated for $\left[1-\mathrm{K}^{-}, \mathrm{C}_{17} \mathrm{H}_{12} \mathrm{ClN}_{2} \mathrm{O}_{3} \mathrm{PtS}\right.$, 553.990 .

Elem. calculated for $\mathrm{C}_{17} \mathrm{H}_{16} \mathrm{ClKN}_{2} \mathrm{O}_{5} \mathrm{PtS} \cdot 2\left(\mathrm{H}_{2} \mathrm{O}\right): \mathrm{C}, 32.41 ; \mathrm{H}, 2.56 ; \mathrm{N}, 4.45$. Found $\mathrm{C}$, 32.35; H, 2.84; N, 4.46 . 


\section{( $\left.\mathrm{C}_{6} \mathrm{H}_{4-\mathrm{dpms}}\right) \mathrm{Pt}\left(\mathrm{OH}_{2}\right), 7$}

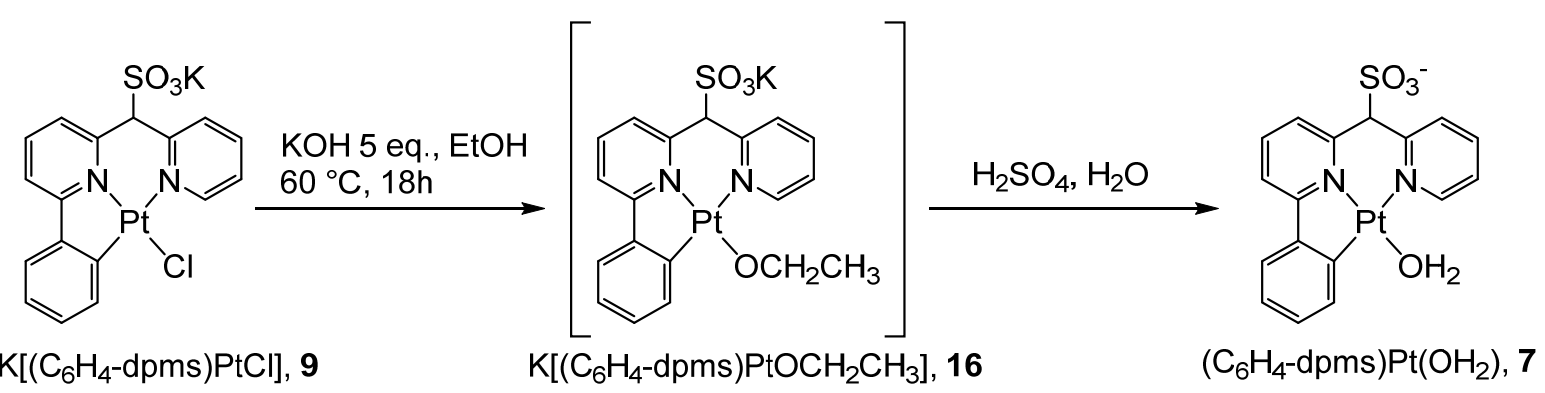

To a Schlenk flask was added $\mathrm{K}\left[\left(\mathrm{C}_{6} \mathrm{H}_{4}-\mathrm{dpms}\right) \mathrm{PtCl}\right], 9(200 \mathrm{mg}, 0.337 \mathrm{mmol})$, along with $10 \mathrm{~mL}$ EtOH. Then $\mathrm{KOH}$ pellets $\left(\sim 85 \% \mathrm{KOH}, \sim 15 \% \mathrm{H}_{2} \mathrm{O}, 115 \mathrm{mg}, 1.75 \mathrm{mmol}, \sim 5 \mathrm{eq}\right.$.) were added. The flask was sealed and heated to $60^{\circ} \mathrm{C}$ while stirring vigorously overnight. The resulting dark red solution containing $\mathbf{1 6}$ was then filtered through Celite. If $\mathbf{9}$ contaminated with $\mathrm{LiCl}$ was used as the starting material then the solution was passed through a $\mathrm{K}^{+}$cation exchange column and filtered again followed by solvent removal in vacuo. The dark red residue containing crude 16 was characterized by ${ }^{1} \mathrm{H}$ NMR and used without purification. The residue was re-dissolved in $3 \mathrm{~mL} \mathrm{EtOH}$, diluted to $9 \mathrm{~mL}$ with DCM and then placed in the fridge. After $1 \mathrm{~h}$ a light colored precipitate had formed which was removed by filtration through Celite. The filter cake was washed with $2 \times 5 \mathrm{~mL}$ of a 2:1 DCM:EtOH solution. The filtrate was stripped of solvent under vacuum and the red residue was dispersed in $10 \mathrm{~mL}$ deionized argon sparged $\mathrm{H}_{2} \mathrm{O}$ to which a few drops of TFE were added until all had dissolved. While stirring vigorously, the $\mathrm{pH}$ was adjusted to 2 using a $1 \mathrm{M} \mathrm{H}_{2} \mathrm{SO}_{4}$ solution. The color turned light yellow followed by the formation of a large amount of fluffy precipitate. The flask was placed in the fridge overnight. The next day small yellow crystals had formed on the walls of the flask which were suitable for XRD along with yellow silty precipitate. The solids were filtered off, washed with deionized $\mathrm{H}_{2} \mathrm{O}$ and dried under vacuum to yield $\mathbf{7} \cdot \mathbf{4} \mathrm{H}_{2} \mathrm{O}(146 \mathrm{mg}, 73 \%)$. Prepared in this manner product usually contains a $1-5 \%$ impurity of 9 , however this does not affect the rate of $\mathrm{CH}$ activation by $\mathbf{7}$. Analytically pure $\mathbf{7} \cdot \mathbf{4} \mathrm{H}_{2} \mathrm{O}$ can be obtained by recrystallization from $\mathrm{TFE} / \mathrm{H}_{2} \mathrm{O}$ to yield yellow crystals $(105 \mathrm{mg}, 51 \%$ ). Complex 7 is soluble in TFE and DMSO, slightly soluble in $\mathrm{MeOH}$, and insoluble in $\mathrm{H}_{2} \mathrm{O} / \mathrm{DCM} / \mathrm{THF} /$ Acetone.

The NMR data below are for soluble DMSO derivative LPt(DMSO):

${ }^{1} \mathrm{H}$ NMR (400 MHz, $22{ }^{\circ} \mathrm{C}$, DMSO-d6), $\delta: 6.25(\mathrm{~s}, 1 \mathrm{H}), 7.24-7.27(\mathrm{~m}, 2 \mathrm{H}), 7.66-7.72(\mathrm{~m}$, $2 \mathrm{H}), 7.76\left(\mathrm{dd},{ }^{3} \mathrm{JHH}_{\mathrm{HH}}=6.0 \mathrm{~Hz},{ }^{4} \mathrm{JHH}_{\mathrm{H}}=2.8 \mathrm{~Hz}, 1 \mathrm{H}\right), 7.88(\mathrm{~m}, 1 \mathrm{H}), 8.00\left(\mathrm{~d},{ }^{3} \mathrm{JHH}_{\mathrm{HH}}=7.6 \mathrm{~Hz}, 1 \mathrm{H}\right)$, 8.18-8.22 (m, 3H), $9.04\left(\mathrm{~d},{ }^{3} \mathrm{JHH}_{\mathrm{HH}}=4.8 \mathrm{~Hz}, 1 \mathrm{H}\right)$.

${ }^{13} \mathrm{C}$ NMR $\left(125 \mathrm{MHz}, 22{ }^{\circ} \mathrm{C}\right.$, DMSO-d6), $\delta: 75.3,119.4,125.3,125.7,125.9,126.9$, $129.3,130.7,134.5,140.5,141.2,140.0,145.9,152.6,152.7,153.7$

ESI-MS of dilute solution of 7 in $\mathrm{H}_{2} \mathrm{O},[2-\mathrm{H}]$ : 536.028 . Calculated for $[2-\mathrm{H}]$ : $\mathrm{C}_{17} \mathrm{H}_{13} \mathrm{~N}_{2} \mathrm{O}_{4} \mathrm{PtS}, 536.025$.

Elem. calculated for $\mathrm{C}_{17} \mathrm{H}_{14} \mathrm{~N}_{2} \mathrm{O}_{4} \mathrm{PtS} \cdot 4\left(\mathrm{H}_{2} \mathrm{O}\right): \mathrm{C}, 33.50 ; \mathrm{H}, 3.64 ; \mathrm{N}, 4.60$. Found: $\mathrm{C}$, $33.47 ; \mathrm{H}, 3.79 ; \mathrm{N}, 4.58$. 


\section{$\left(\mathrm{C}_{6} \mathrm{H}_{4}-\mathrm{dpms}\right)_{\mathrm{nPt}} \mathrm{t}_{\mathrm{n}}, 17$}

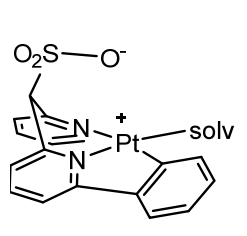

solv $=\mathrm{H}_{2} \mathrm{O}$, TFE

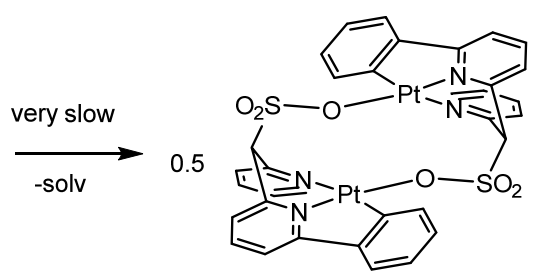

17

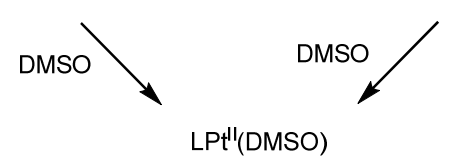

When solutions of 7 in TFE are heated at $80^{\circ} \mathrm{C}$ for a few hours or left at room temperature for a few days, a bright orange precipitate (complex 17) forms. The rate can be followed (see section VII) by monitoring the ${ }^{1} \mathrm{H}-\mathrm{NMR}$ spectrum. At high $\mathrm{H}_{2} \mathrm{O}$ concentrations $(\geq 1 \mathrm{M}$ ) the rate is diminished. $7.0 \mathrm{mg}(12 \mu \mathrm{mol}) \mathbf{7} \cdot \mathbf{4} \mathrm{H}_{2} \mathrm{O}$ was dissolved in TFE and heated at 80 ${ }^{\circ} \mathrm{C}$ for $24 \mathrm{~h}$. The red precipitate was collected by filtration and dried under high vacuum to yield $3.1 \mathrm{mg} 17(3.0 \mu \mathrm{mol}, 52 \%)$. A sample of 17 that had been collected by filtration and dried under high vacuum, when dissolved in DMSO-d6, gave the DMSO derivative $\left(\mathrm{C}_{6} \mathrm{H}_{4}\right.$-dpms) $\mathrm{Pt}(\mathrm{DMSO})$ and $<0.2$ eq. $\mathrm{H}_{2} \mathrm{O}$ and no detectable TFE, suggesting 17 contains virtually no solvento ligands. When $\mathrm{HBF}_{4}$ or $\mathrm{KCl}$ is added to a suspension of $\mathbf{1 7}$ in TFE the solid redissolves and forms $\mathbf{1 3} \cdot \mathbf{H}^{+}$or $\mathbf{9}$, respectively (Scheme S1), within $\sim 15$ minutes. These results are consistent with the dimerization of $\mathbf{7}$ in TFE to form 17.

17

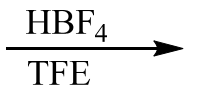<smiles></smiles>

$[13+\mathrm{H}]^{+}$

17<smiles></smiles>

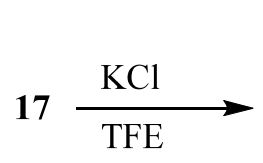

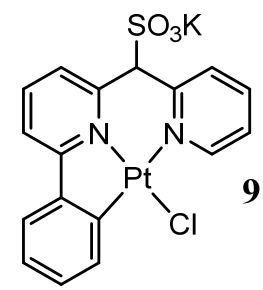

Scheme S1. Transformations of $\mathbf{1 7}$ to form other $\left(\mathrm{C}_{6} \mathrm{H}_{4}-\mathrm{dpms}\right) \mathrm{Pt}$ derivatives. 


\section{Major Species in Solution and Effect of $\mathrm{H}_{2} \mathrm{O}$ and Temperature}

When yellow crystalline $\left(\mathrm{C}_{6} \mathrm{H}_{4}-\mathrm{dpms}\right) \mathrm{Pt}\left(\mathrm{OH}_{2}\right), 7$, is placed in TFE dissolution takes $2-10$ minutes depending on concentration: a saturated solution has a concentration of about $20 \mathrm{mM}$. Initially the solutions are yellow but quickly turn very dark orange-brown. ${ }^{1} \mathrm{H}-\mathrm{NMR}$ in $\mathrm{CF}_{3} \mathrm{CH}_{2} \mathrm{OH}$ shows a new broad singlet at approximately $7.61 \mathrm{ppm}$ which is made broader and shifted downfield by the addition of $\mathrm{H}_{2} \mathrm{O}$, assigned to a pyridinium proton. This broad singlet is not present in TFE- $\mathrm{d}_{1}$ solutions and so must be exchangeable (Figure S1). A control experiment without 7 also shows no singlet at $7.61 \mathrm{ppm}$ or any peaks above $5.50 \mathrm{ppm}$. Unfortunately neither ${ }^{1} \mathrm{H}$ nor ${ }^{13} \mathrm{C}$ NMR yields observable Pt-sattelites, possibly due to chemical shift anisotropy result in extreme line broadening of the satellite peaks.
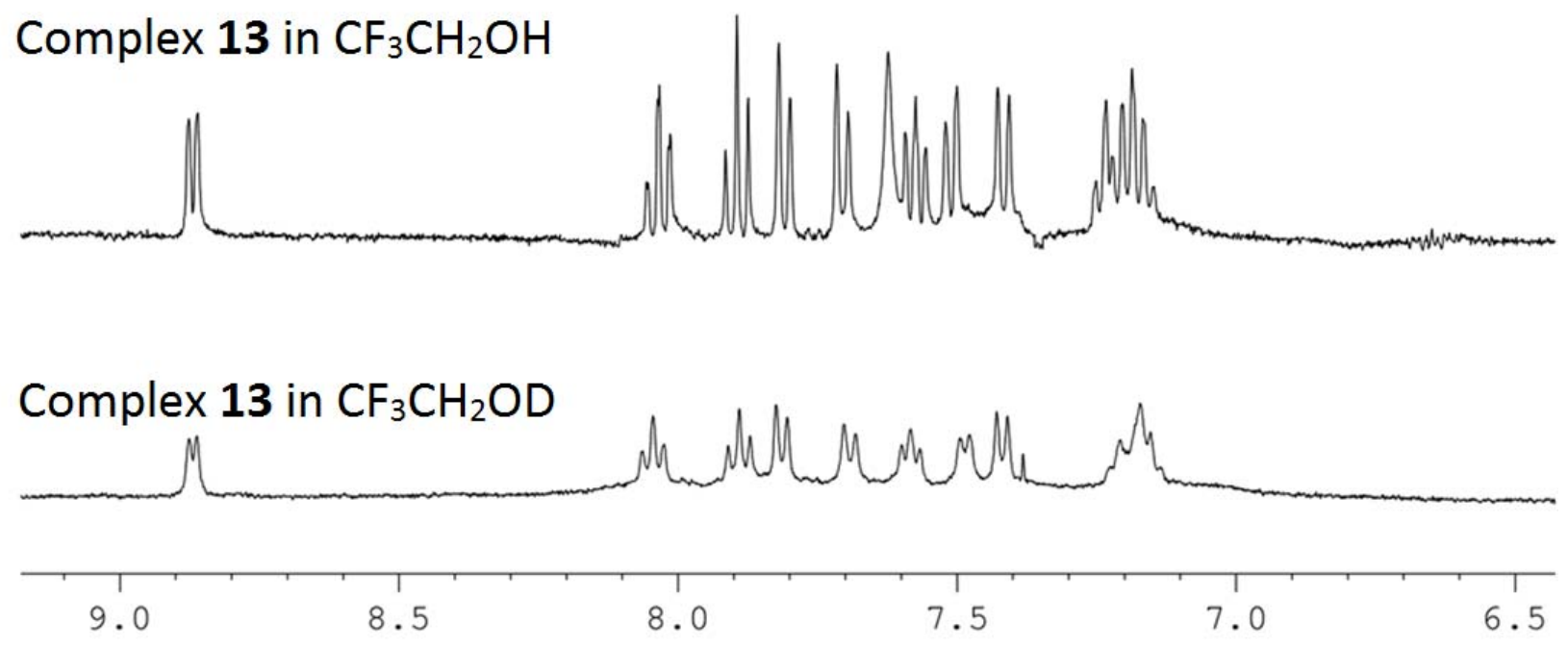

Figure S1. Comparison of aromatic region of ${ }^{1} \mathrm{H}-\mathrm{NMR}$ spectra of 13 in TFE and TFE- $\mathrm{d}_{1}$ showing the absence of the pyridinium singlet at $7.61 \mathrm{ppm}$ when TFE- $\mathrm{d}_{1}$ is used.

${ }^{1} \mathrm{H}$ NMR $\left(400 \mathrm{MHz}, 22{ }^{\circ} \mathrm{C}, \mathrm{TFE}\right), \delta: 5.73(\mathrm{~s}, 1 \mathrm{H}), 7.10-7.24(\mathrm{~m}, 3 \mathrm{H}), 7.41\left(\mathrm{~d},{ }^{3} \mathrm{~J}_{\mathrm{HH}}=7.6\right.$ $\mathrm{Hz}, 1 \mathrm{H}), 7.48\left(\mathrm{~d},{ }^{3} \mathrm{JHH}_{\mathrm{HH}}=7.6 \mathrm{~Hz}, 1 \mathrm{H}\right), 7.56\left(\mathrm{vt},{ }^{3} \mathrm{~J}_{\mathrm{HH}}=6.5 \mathrm{~Hz}, 1 \mathrm{H}\right), 7.60(\mathrm{~s}, 1 \mathrm{H}), 7.68(\mathrm{vd}$, $\left.{ }^{3} J_{\mathrm{HH}}=8.0 \mathrm{~Hz}, 1 \mathrm{H}\right), 7.80\left(\mathrm{~d},{ }^{3} \mathrm{JHH}_{\mathrm{HH}}=8.0,1 \mathrm{H}\right), 7.88\left(\mathrm{vt},{ }^{3} \mathrm{JHH}_{\mathrm{HH}}=7.9 \mathrm{~Hz}, 1 \mathrm{H}\right), 8.02\left(\mathrm{vt},{ }^{3} \mathrm{JHH}_{\mathrm{HH}}=\right.$ $7.9 \mathrm{~Hz}, 1 \mathrm{H}), 8.86\left(\mathrm{~d},{ }^{3} \mathrm{JHH}_{\mathrm{H}}=5.6 \mathrm{~Hz}, 1 \mathrm{H}\right)$

${ }^{13} \mathrm{C}$ NMR $\left(125 \mathrm{MHz}, 22{ }^{\circ} \mathrm{C}\right.$, TFE), $\delta: 76.36,118.49,124.00,124.85,125.09,125.80$, $129.15,129.40,131.18,139.14,139.66,140.59,145.21,147.87,149.97,150.84,169.27$

The ESI-MS(+) spectrum of a TFE solution of complex 7 containing $\mathrm{NaBAr}_{4}$ provided peaks at $664.03 \mathrm{M} / \mathrm{Z}[14-\mathrm{H}+2 \mathrm{Na}]^{+}, 642.04 \mathrm{M} / \mathrm{Z}[14+\mathrm{Na}]^{+}$(both weak) and $560.02 \mathrm{M} / \mathrm{Z}$ $[7+\mathrm{Na}]^{+}$(the strongest). The ESI-MS(-) spectrum contained only one peak at $618.06 \mathrm{M} / \mathrm{Z}$ $[14-\mathrm{H}]^{-}$. 


\section{B. Attempted Isolation of Complex 13}

A $0.5 \mathrm{~mL}$ TFE solution in which complex $7(7.0 \mathrm{mg}, 11.5 \mu \mathrm{mol})$ had been dissolved, and thus contained $\sim 10 \mu \mathrm{mol} 13$, was either a) subjected to high vacuum until all solvent had been removed or b) precipitated with $4 \mathrm{~mL} \mathrm{Et}_{2} \mathrm{O}$, decanted, washed with $\mathrm{THF}$ and dried under high vacuum. In both cases, the brown residue was found to be completely insoluble in Acetone, DCM, or THF. When dissolved in DMSO-d6, the only complex observed in solution was $\left(\mathrm{C}_{6} \mathrm{H}_{4}-\mathrm{dpms}\right) \mathrm{Pt}(\mathrm{DMSO})$. By comparing the spectra to that of pure DMSO-d6, the amount of $\mathrm{H}_{2} \mathrm{O}$ and TFE contained in the brown residue could be determined (Table S1).

Table S1. Equivalents of $\mathrm{H}_{2} \mathrm{O}$ and TFE released upon dissolution in DMSO-d6.

\begin{tabular}{|c|c|c|}
\hline Method & Eq. $\mathrm{H}_{2} \mathrm{O}$ & Eq. TFE \\
\hline a) Solvent Removal & 3.2 & 0.24 \\
\hline b) Precipitation & 1.9 & 0.18 \\
\hline
\end{tabular}

\section{Effect of $\mathrm{H}_{2} \mathrm{O}$}

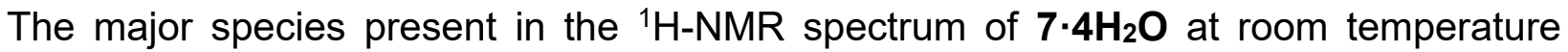
shows sharp signals. However a highly fluxional minor species is present $(\sim 15 \%)$ which has very broad signals (Figure S2). When crystalline $\mathbf{7} \cdot \mathbf{4} \mathrm{H}_{2} \mathrm{O}$ was dried under high vacuum the amount of $\mathrm{H}_{2} \mathrm{O}$ contained within the solid matrix was found to decrease (Table S2). The batches of 7 containing less $\mathrm{H}_{2} \mathrm{O}$, when dissolved in TFE, gave rise to higher fractions of the species exhibiting broad signals. The effect was farther studied by adding $\mathrm{H}_{2} \mathrm{O}$ and analyzing the ${ }^{1} \mathrm{H}-\mathrm{NMR}$ spectra at $80{ }^{\circ} \mathrm{C}$ (Figure S3) where both sets of signals are relatively sharp and easier to integrate. The data clearly shows that the species with sharp signals which is the major at room temperature is favored at higher $\left[\mathrm{H}_{2} \mathrm{O}\right]$.

Table S2. Effect of $\mathrm{H}_{2} \mathrm{O}$ on the two major species present in TFE solutions of 7.

\begin{tabular}{|c|c|c|c|c|}
\hline $\begin{array}{c}\text { Complex } \\
(4.0 \mathrm{mg})\end{array}$ & Hours Dried & Temperature $\left({ }^{\circ} \mathrm{C}\right)$ & {$\left[\mathrm{H}_{2} \mathrm{O}\right]_{\text {tot }}(\mathrm{M})$} & Broad/Sharp \\
\hline $\mathbf{7} \cdot \mathbf{4} \mathrm{H}_{2} \mathbf{O}$ & 0 & 21 & 0.060 & $\sim 0.2$ \\
\hline $\mathbf{7} \cdot \mathbf{0 . 6 \mathrm { H } _ { 2 } \mathbf { O }}$ & 2 & 21 & 0.025 & $\sim 0.5$ \\
\hline $\mathbf{7}$ & 18 & 21 & 0.015 & $\sim 0.9$ \\
\hline $\mathbf{7} \cdot 3 \mathrm{H}_{2} \mathbf{O}$ & 0.5 & 80 & 0.049 & 3.71 \\
\hline $\mathbf{7} \cdot 3 \mathrm{H}_{2} \mathbf{O}$ & 0.5 & 80 & 0.104 & 1.99 \\
\hline $\mathbf{7} \cdot 3 \mathrm{H}_{2} \mathbf{O}$ & 0.5 & 80 & 0.268 & 0.454 \\
\hline $\mathbf{7} \cdot 3 \mathrm{H}_{2} \mathbf{O}$ & 0.5 & 80 & 0.486 & 0.171 \\
\hline $\mathbf{7} \cdot 3 \mathrm{H}_{2} \mathbf{O}$ & 0.5 & 80 & 0.759 & 0.065 \\
\hline $\mathbf{7} \cdot 3 \mathrm{H}_{2} \mathbf{O}$ & 0.5 & 80 & 1.03 & 0.029 \\
\hline
\end{tabular}




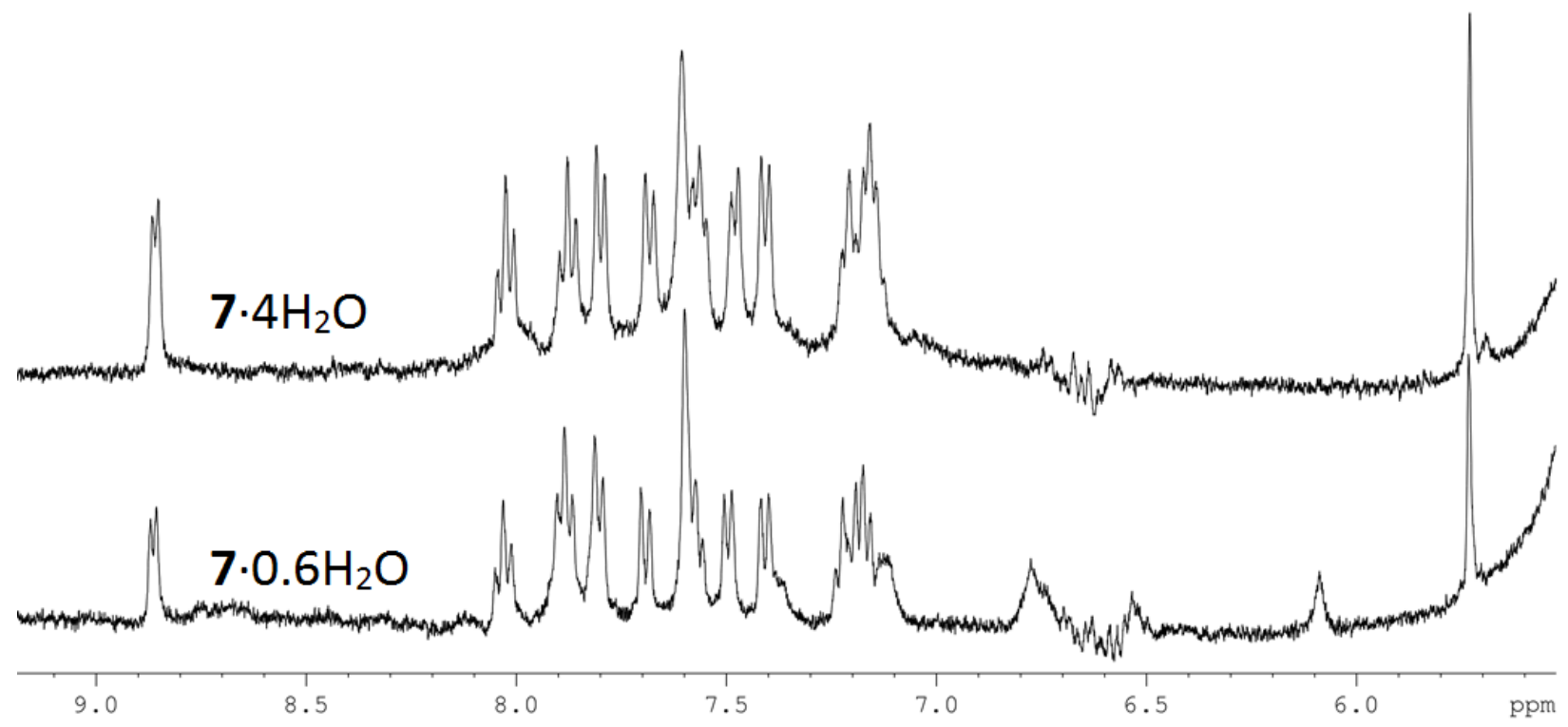

Figure S2. Aromatic region in ${ }^{1} \mathrm{H}-\mathrm{NMR}$ of complex $7 \cdot \mathrm{nH}_{2} \mathrm{O}$ in TFE at $21^{\circ} \mathrm{C}$ showing new species with broadened peaks at low $\mathrm{H}_{2} \mathrm{O}$ concentration.

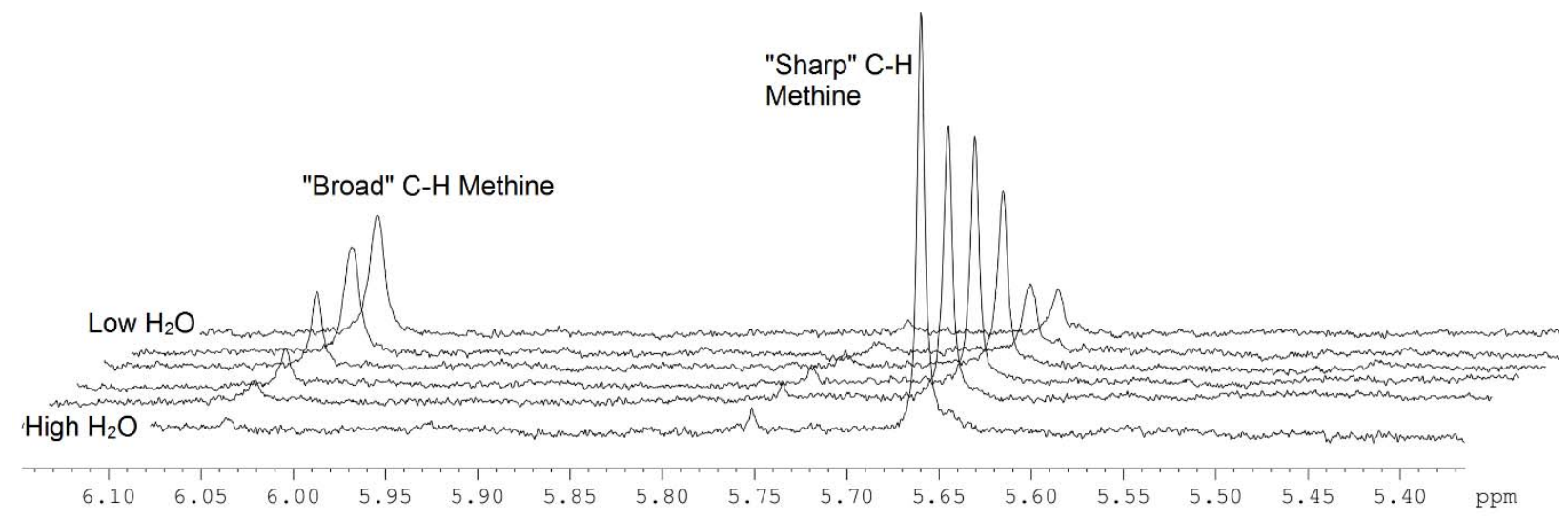

Figure S3. Bridging $\mathrm{C}-\mathrm{H}$ methine ${ }^{1} \mathrm{H}-\mathrm{NMR}$ singlets at $80^{\circ} \mathrm{C}$ used to find the ratio between the two major species in solution. 


\section{VT-NMR and van't Hoff's Plots of solutions of 7 in TFE}

An NMR Young tube equipped with a sealable Teflon cap and sealed capillary tube containing $\mathrm{D}_{2} \mathrm{O}$ was taken into an argon filled glovebox and charged with $0.5 \mathrm{~mL}$ of a TFE solution containing $\mathbf{7} \cdot 2 \mathrm{H}_{2} \mathrm{O}(13.1 \mathrm{mM}), \mathrm{C}_{6} \mathrm{D}_{6}(0$ or $1.13 \mathrm{M})$, and $\mathrm{H}_{2} \mathrm{O}(60 \mathrm{mM}$ from the hydrate). The solution was monitored by ${ }^{1} \mathrm{H}-\mathrm{NMR}$ over $21^{\circ} \mathrm{C}-80^{\circ} \mathrm{C}$. The bridging methine $\mathrm{CH}$ singlets at $5.66 \mathrm{ppm}$ and $6.01 \mathrm{ppm}$ were used to monitor the ratio between the two $\left(\mathrm{C}_{6} \mathrm{H}_{4}\right.$-dpms) Pt(solv) species in solution at $40^{\circ} \mathrm{C}$ and above (Figure S4). In the $21^{\circ} \mathrm{C}$ experiments extreme broadening of the $6.01 \mathrm{ppm}$ signal was observed and the $\mathrm{LPt}(\mathrm{solv})$ ratio was found by integrating the whole aromatic region of the spectrum (assignable to both solv $=$ TFE and $\mathrm{H}_{2} \mathrm{O}$ species) and a standing alone sharp multiplet at $5.66 \mathrm{ppm}$ assigned to 13 . Virtually the same $\mathrm{LPt}(\mathrm{TFE}) / \mathrm{LPt}\left(\mathrm{H}_{2} \mathrm{O}\right)$ ratios were found whether the temperature was ramping up or down (demonstrating reversibility) and whether or not benzene was present or absent in the mixtures. The reported Keq values are given in Table S3.

$$
K_{e q}=\frac{[\operatorname{LPt}(H 2 O)][T F E]}{[\operatorname{LPt}(\mathrm{TFE})][\mathrm{H} 2 \mathrm{O}]}
$$

where $[$ TFE $]=12.46 \mathrm{M}(10$ vol. $\%$ benzene $)$ or $13.84 \mathrm{M}$ (neat TFE); $\left[\mathrm{H}_{2} \mathrm{O}\right]=0.030 \mathrm{M}$

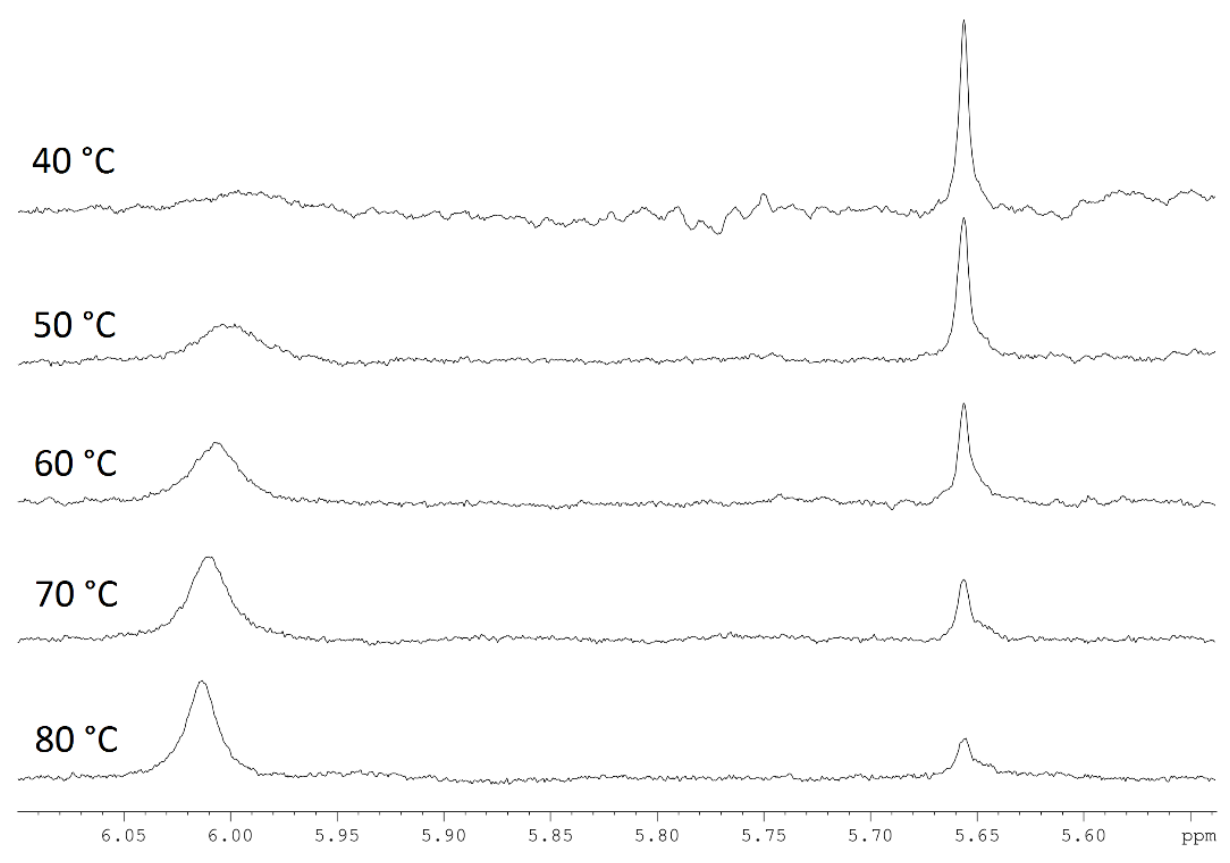

Figure S4. Fragments of the ${ }^{1} \mathrm{H}-\mathrm{NMR}$ spectra in the range $5.5-6.1 \mathrm{ppm}$ used to monitor the equilibrium. 
Table S3. ${ }^{1} \mathrm{H}-\mathrm{NMR}$ Integrations for solution of 7 (13.1 mM) and $\mathrm{H}_{2} \mathrm{O}(30 \mathrm{mM})$.

\begin{tabular}{|c|c|c|c|c|c|}
\hline Temp & & Integratio & & & \\
\hline${ }^{\circ} \mathrm{C}$ & $K$ & $5.66 \mathrm{ppm}$ & $6.01 \mathrm{ppm}$ & Ratio & $K_{\text {eq }}$ \\
\hline 80 & 353.15 & 1.00 & 5.84 & 5.84 & 1348 \\
\hline 70 & 343.15 & 1.00 & 3.69 & 3.69 & 850 \\
\hline 60 & 333.15 & 1.00 & 2.04 & 2.04 & 471 \\
\hline 50 & 323.15 & 1.00 & 1.25 & 1.25 & 289 \\
\hline
\end{tabular}

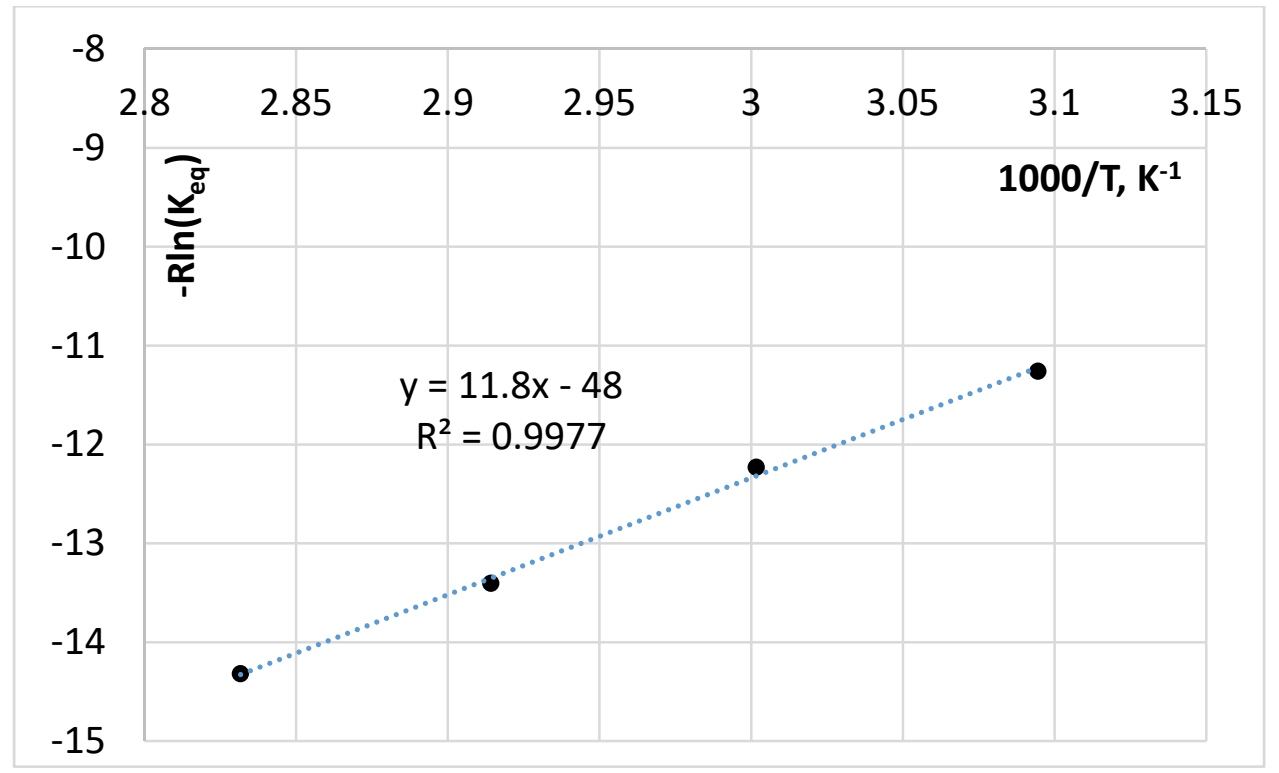

Figure S5. van't Hoff plot for solution of $7(13.1 \mathrm{mM})$ and $\mathrm{H}_{2} \mathrm{O}(60 \mathrm{mM})$ in TFE. $\Delta \mathrm{H}=11.8 \pm 0.4 \mathrm{kcal} / \mathrm{mol}, \Delta \mathrm{S}=48 \pm 1 \mathrm{cal} / \mathrm{K} \mathrm{mol}, \Delta \mathrm{G}=-2.3 \mathrm{kcal} / \mathrm{mol}$ at $25^{\circ} \mathrm{C}$.

Table S4. ${ }^{1} \mathrm{H}-\mathrm{NMR}$ integrations for solution of 7 (13.1 mM), $\mathrm{C}_{6} \mathrm{D}_{6}(1.13 \mathrm{M}), \mathrm{H}_{2} \mathrm{O}(30 \mathrm{mM})$ in TFE

\begin{tabular}{|cc|cc|c|c|}
\hline \multicolumn{2}{|c|}{ Temp } & \multicolumn{2}{c|}{ Integrations } & \multicolumn{2}{c}{} \\
\cline { 1 - 4 }${ }^{\circ} \mathrm{C}$ & $\mathrm{K}$ & $5.66 \mathrm{ppm}$ & $6.01 \mathrm{ppm}$ & Ratio & $K_{\text {eq }}$ \\
\hline 80 & 353.15 & 1.00 & 5.69 & 5.69 & 1180 \\
70 & 343.15 & 1.00 & 3.19 & 3.19 & 662 \\
60 & 333.15 & 1.00 & 2.03 & 2.03 & 421 \\
50 & 323.15 & 1.00 & 1.13 & 1.13 & 235 \\
40 & 313.15 & 1.00 & 0.65 & 0.65 & 135 \\
21 & 294.15 & - & - & 0.18 & 37.4 \\
\hline
\end{tabular}




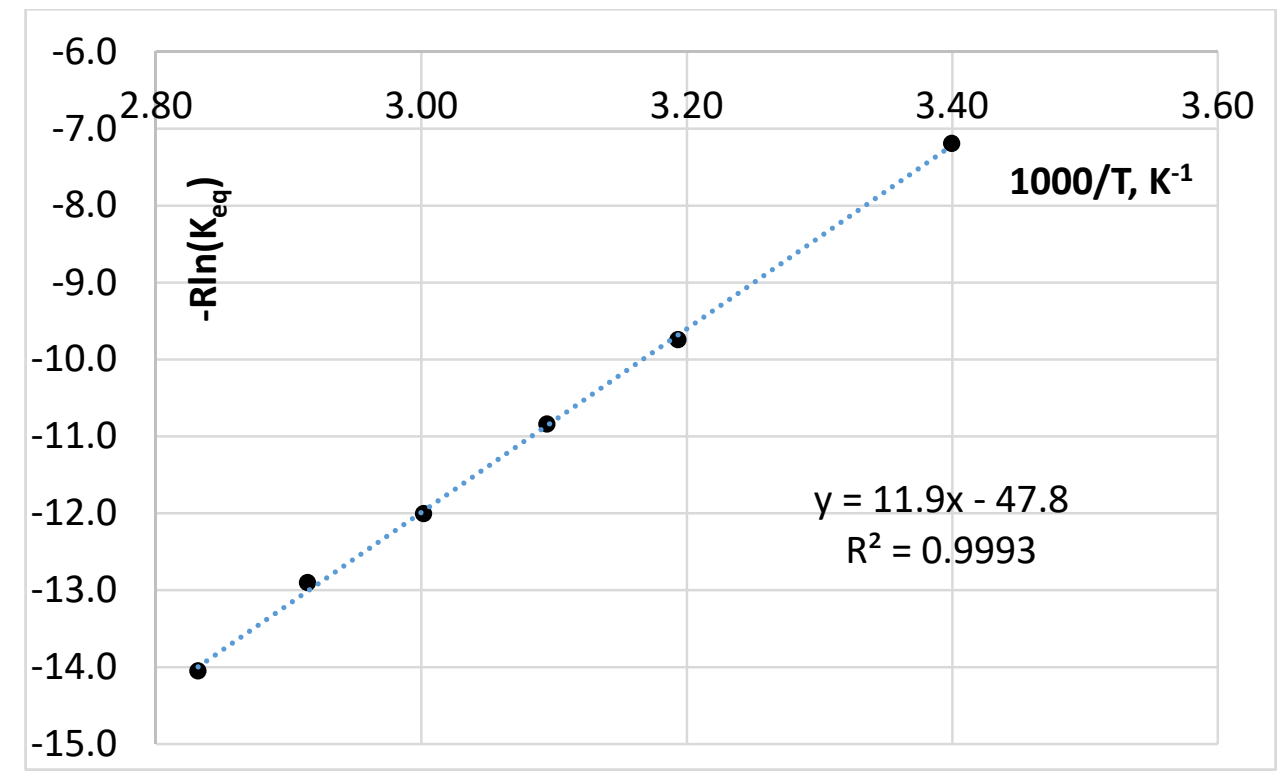

Figure S6. van't Hoff Plot for solution of 7 (13.1 mM), $\mathrm{C}_{6} \mathrm{D}_{6}(1.13 \mathrm{M}), \mathrm{H}_{2} \mathrm{O}(60 \mathrm{mM})$ in TFE. $\Delta H=11.9 \pm 0.1 \mathrm{kcal} / \mathrm{mol}, \Delta S=47.8 \pm 0.4 \mathrm{cal} / \mathrm{K} \mathrm{mol}, \Delta G=-2.3 \mathrm{kcal} / \mathrm{mol}$ at $25^{\circ} \mathrm{C}$. 


\section{General Procedures for H/D Exchange Reactions}

\section{A. General procedure for $\mathrm{H} / \mathrm{D}$ exchange reactions}

To a scintillation vial was added $\mathbf{7} \cdot \mathbf{4} \mathrm{H}_{2} \mathrm{O}(4.0 \mathrm{mg}, 6.7 \mu \mathrm{mol})$ and then brought into an argon filled glovebox. De-gassed TFE $(0.45 \mathrm{~mL})$ and $\mathrm{C}_{6} \mathrm{D}_{6}(0.05 \mathrm{~mL})$ were then added. After about 10 minutes all had dissolved to form a reddish brown solution which was then transferred to an NMR Young tube equipped with a sealable Teflon cap. For locking and shimming purposes, $\mathrm{a}_{2} \mathrm{O}$ containing capillary tube that had been flame sealed on both ends was inserted. The NMR tube was removed from the glove box and charged with $15 \mathrm{psi}$ argon on a Schlenk line to prevent refluxing at $80^{\circ} \mathrm{C}$. After taking an initial ${ }^{1} \mathrm{H}-\mathrm{NMR}$ spectrum the NMR tube was submerged in a pre-heated bath at $80^{\circ} \mathrm{C}$ and periodically removed for ${ }^{1} \mathrm{H}-\mathrm{NMR}$ analysis. All reactions were run at least twice. The TFE $\mathrm{CH}_{2}$ quartet at $3.9 \mathrm{ppm}$ was used as an internal standard to monitor the growth of the benzene $\mathrm{CH}$ singlet at $7.48 \mathrm{ppm}$ (Figure S7). To track the disappearance of 13, either the ortho pyridyl $\mathrm{CH}$ doublet at $8.87 \mathrm{ppm}$ or the bridging methine singlet at 5.74 ppm were monitored. All reactions were run at least twice and for at least $20 \mathrm{~h}$. A control reaction containing only $10 \% \mathrm{v} / \mathrm{v}_{6} \mathrm{C}_{6} \mathrm{D}_{6}$ in TFE showed no detectable $\mathrm{H} / \mathrm{D}$ exchange.

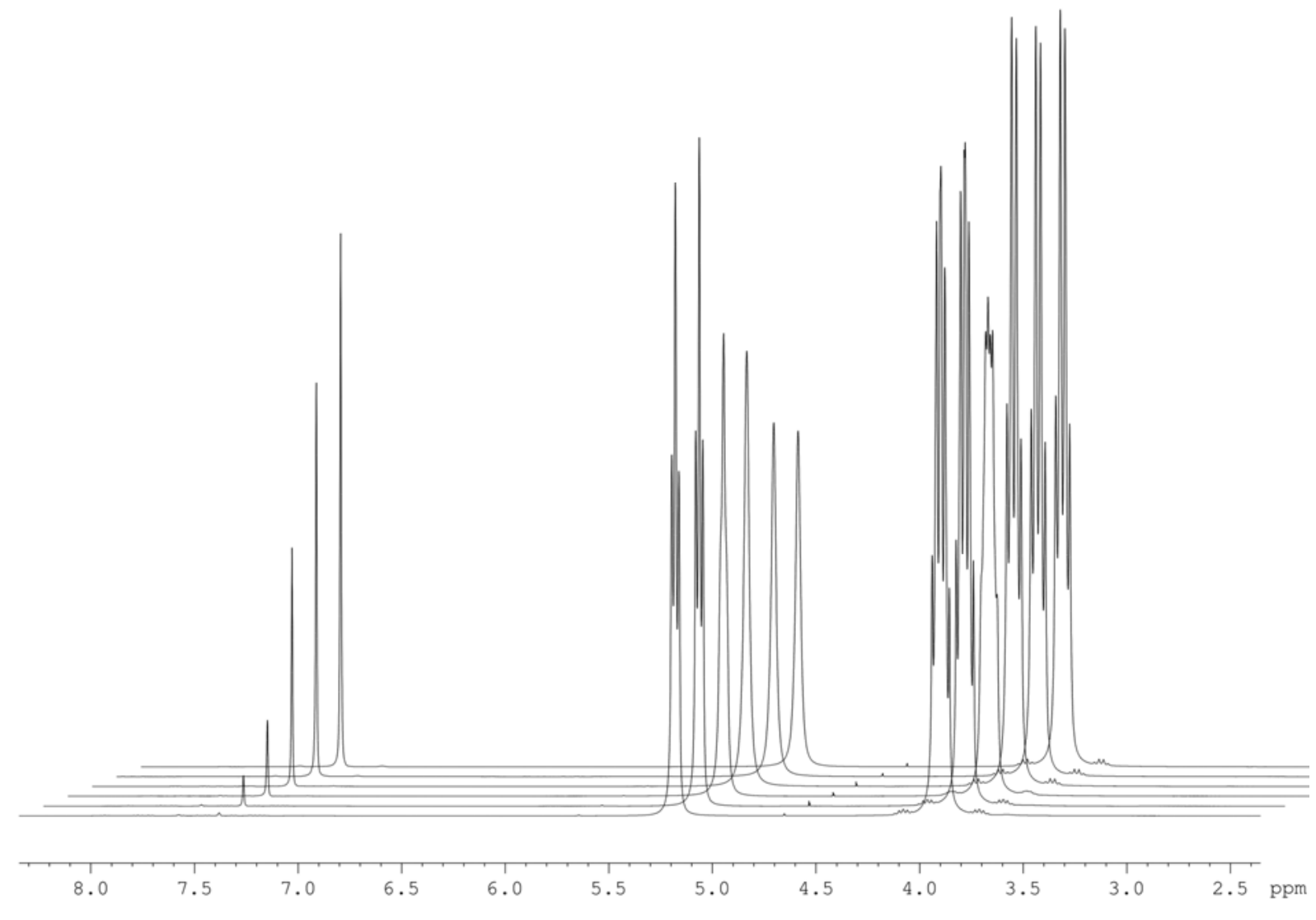

Figure S7. Example of ${ }^{1} \mathrm{H}-\mathrm{NMR}$ spectra from a typical $\mathrm{H} / \mathrm{D}$ exchange experiment. 


\section{H/D Exchange Reactions}

\section{Benzene $\mathrm{C}\left(\mathrm{sp}^{2}\right)-\mathrm{D}$ exchange with TFE mediated by complex 7}

General procedure A was followed. The reaction was monitored at $80^{\circ} \mathrm{C}, 60^{\circ} \mathrm{C}, 40^{\circ} \mathrm{C}$, and $21^{\circ} \mathrm{C}$. The $21^{\circ} \mathrm{C}$ reaction was carried out at room temperature beside a thermometer. The thermometer was monitored during the day and at night giving temperature of $21 \pm 1$ ${ }^{\circ} \mathrm{C}$. The other three reactions were carried out in a temperature controlled bath which did not vary more than $\pm 0.1^{\circ} \mathrm{C}$ from the temperature reported.

The $\mathrm{k}_{1 \text { obs }}$ for $\mathrm{C}-\mathrm{D}$ bond activation and $\mathrm{k}_{2}$ for precipitation of $\mathbf{1 7}$ is listed beneath each graph in Fig. S8. The reverse $\mathrm{k}_{-2}$ for dissolution of the orange precipitate 17 was found to have a best fit equal to $0\left(\mathrm{M} \cdot \mathrm{s}^{-1}\right)$ in every case and so is not listed.

The natural log of the $k_{10 b s}$ values were then plotted against $1 / T$ to create an Eyring plot (Figure S9) from which the activation parameters could be found.

To determine the reaction initial rates, the mixtures were monitored for periods of time allowing to achieve $<5 \%$ of all substrate $\left(\mathrm{C}_{6} \mathrm{D}_{6}\right.$ or $\left.\mathrm{C}_{6} \mathrm{H}_{6}\right)$ conversion.

a) Reaction at $80^{\circ} \mathrm{C}$
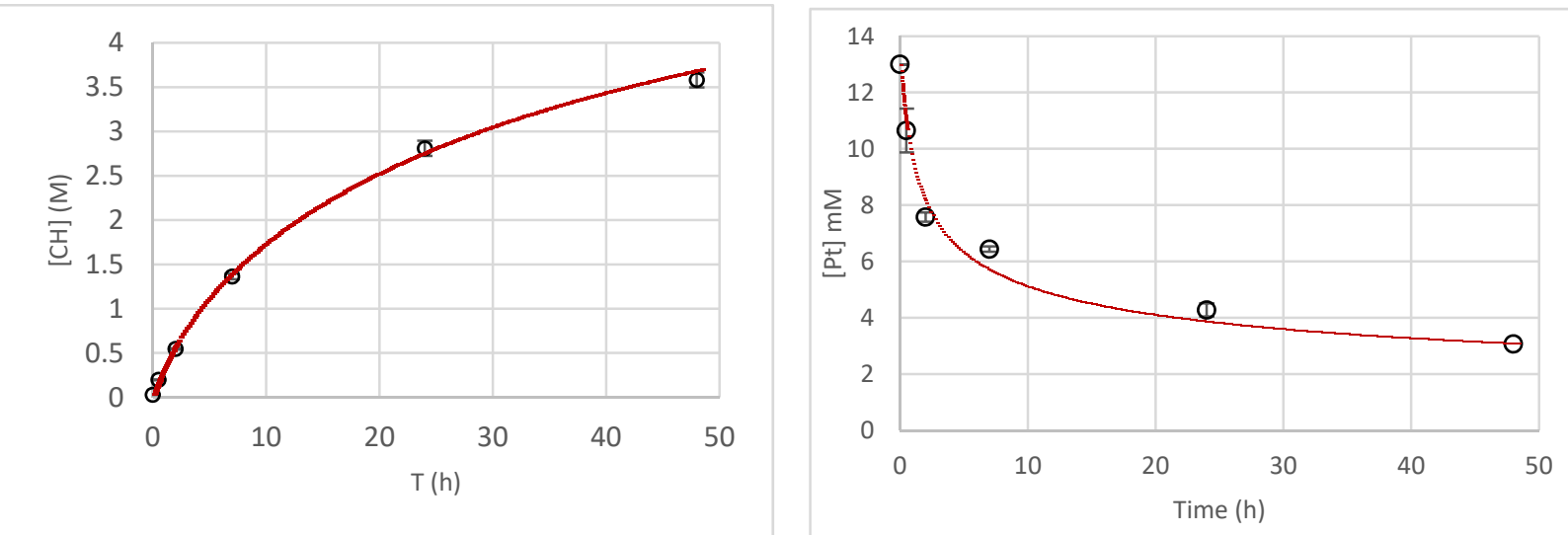

$[\mathrm{Pt}]_{\text {init }}=13.1 \mathrm{mM}, \mathrm{k}_{1 \text { obs }}=1.27 \pm 0.05 \times 10^{-3}\left(\mathrm{M}^{-1} \cdot \mathrm{s}^{-1}\right), \mathrm{k}_{2}=1.1 \pm 0.2\left(\mathrm{M}^{-3} \cdot \mathrm{s}^{-3}\right)$

b) Reaction at $60^{\circ} \mathrm{C}$
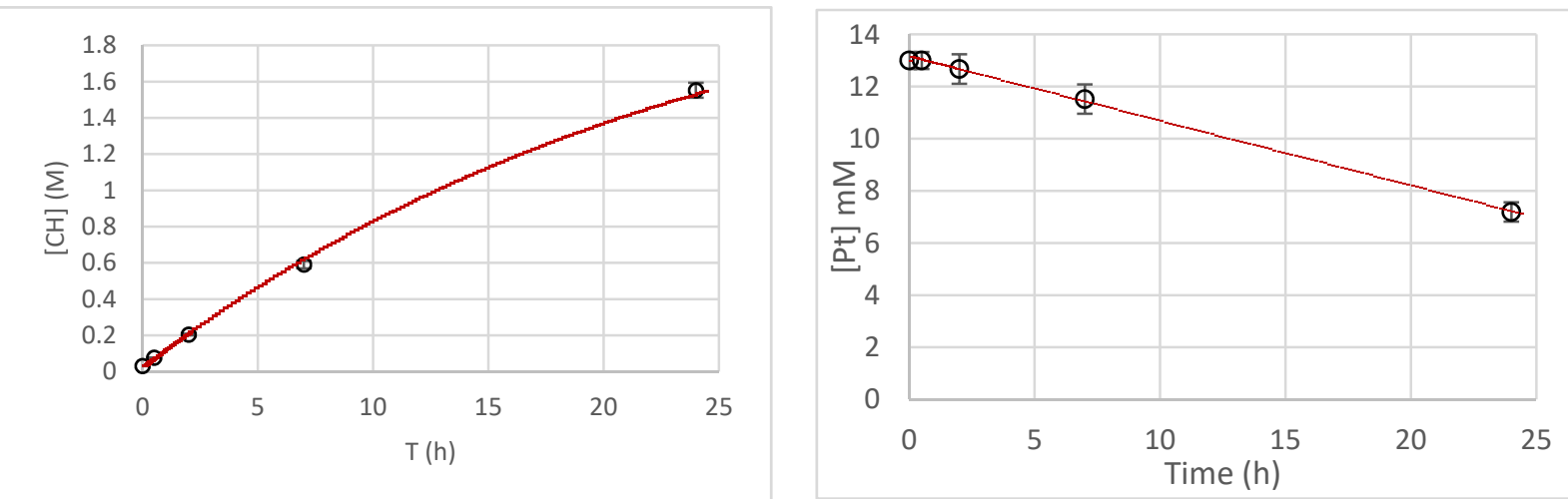

$[\mathrm{Pt}]_{\text {init }}=13.1 \mathrm{mM}, \mathrm{k}_{1 \mathrm{obs}}=3.1 \pm 0.1 \times 10^{-4}\left(\mathrm{M}^{-1} \cdot \mathrm{s}^{-1}\right), \mathrm{k}_{2 \text { precip }}=0.078 \pm 0.005\left(\mathrm{M}^{-3} \cdot \mathrm{s}^{-3}\right)$ 
c) Reaction at $40{ }^{\circ} \mathrm{C}$
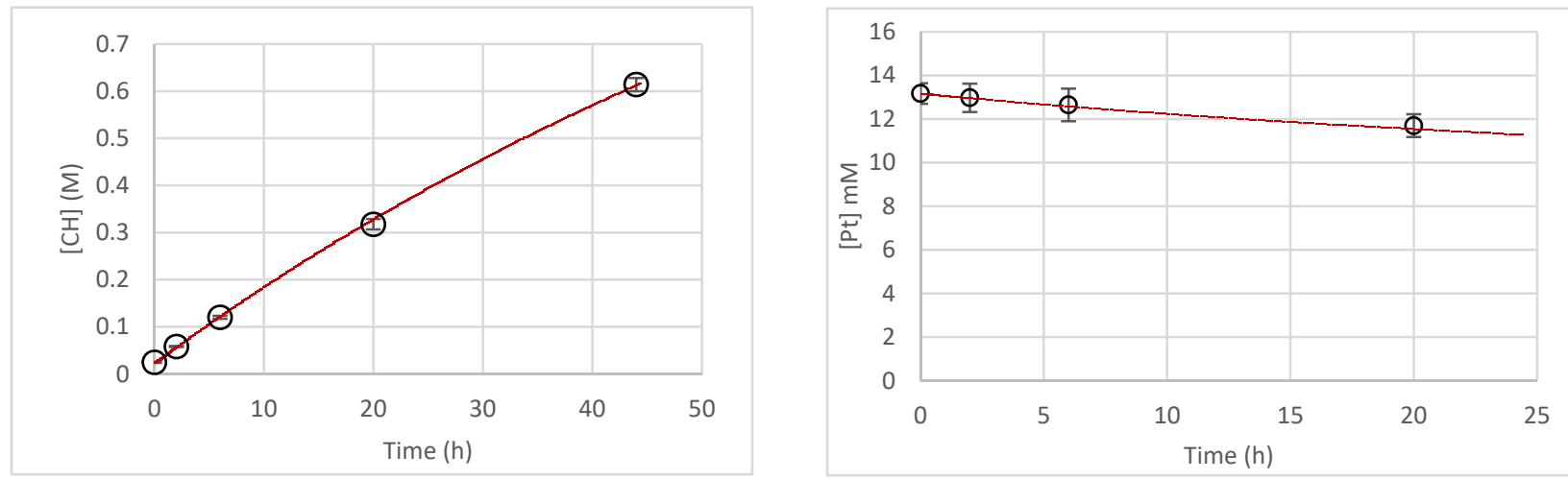

$[\mathrm{Pt}]_{\mathrm{init}}=13.1 \mathrm{mM}, \mathrm{k}_{1 \mathrm{obs}}=5.2 \pm 0.2 \times 10^{-5}\left(\mathrm{M}^{-1} \cdot \mathrm{s}^{-1}\right), \mathrm{k}_{2 \text { precip }}=0.017 \pm 0.005\left(\mathrm{M}^{-3} \cdot \mathrm{s}^{-3}\right)$

d) Reaction at $21^{\circ} \mathrm{C}$

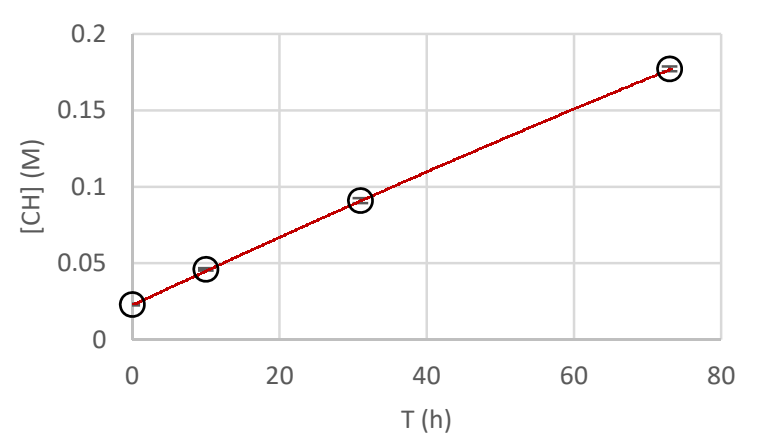

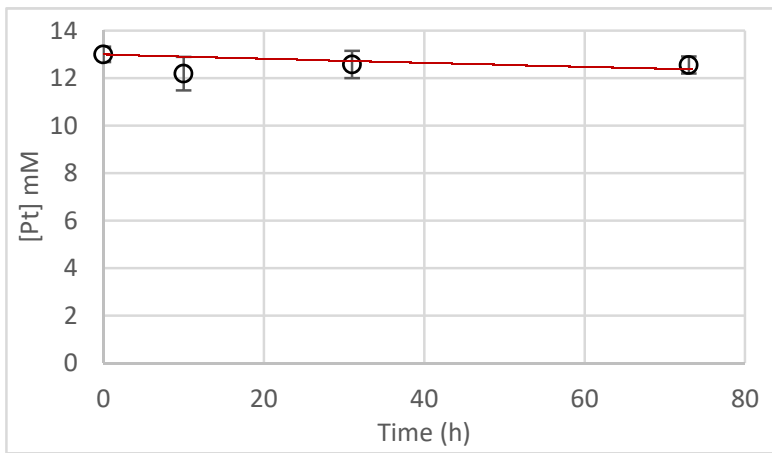

$[\mathrm{Pt}]_{\mathrm{init}}=13.1 \mathrm{mM}, \mathrm{k}_{1 \mathrm{obs}}=7.1 \pm 0.1 \times 10^{-6}\left(\mathrm{M}^{-1} \cdot \mathrm{s}^{-1}\right), \mathrm{k}_{2 \text { precip }}=1.6 \pm 0.4 \times 10^{-3}\left(\mathrm{M}^{-3} \cdot \mathrm{s}^{-3}\right)$

Figure S8. The reaction profiles (graphs a-c, left) for the $\mathrm{H} / \mathrm{D}$ exchange between

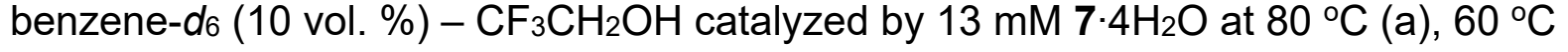
(b), $40^{\circ} \mathrm{C}$ (c) and $21^{\circ} \mathrm{C}$ (d). Black circles: experimental data; red points correspond to the TON predicted by the reaction model in Scheme 6 . The reaction profiles in the right correspond to the consumption of 7 to form 17. 


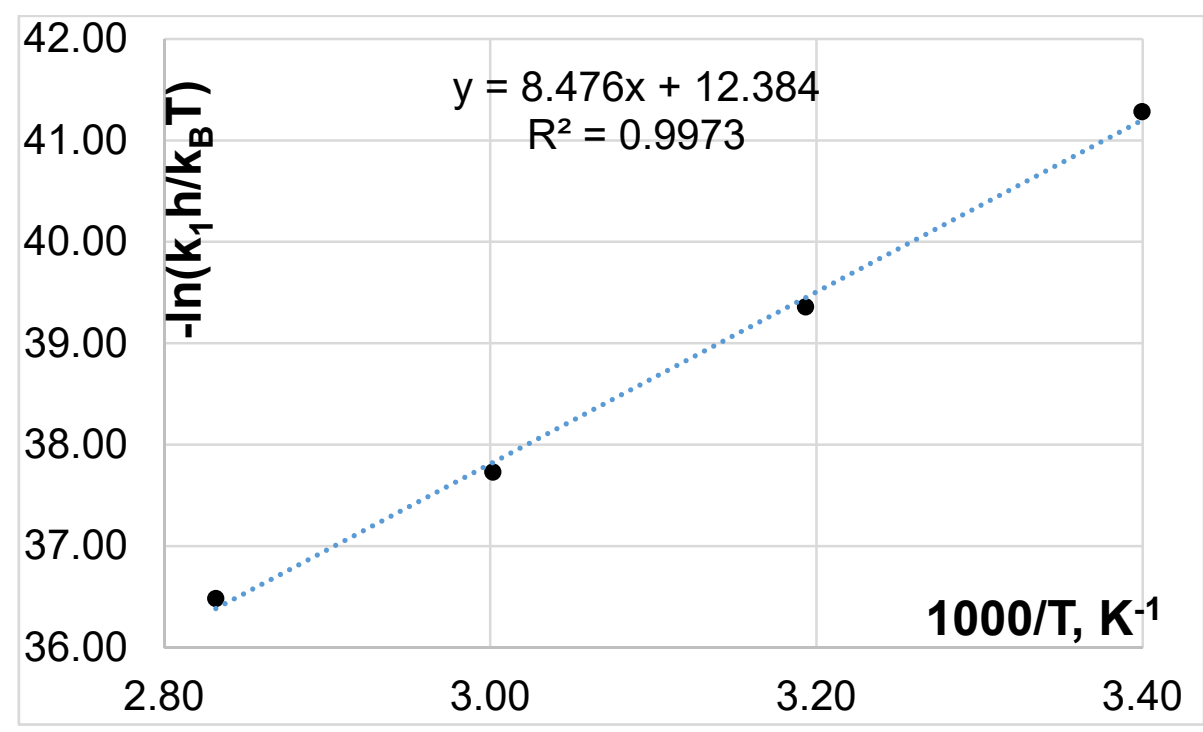

Figure S9. Eyring plot showing linear correlation between $\ln \left(\mathrm{k}_{10 \mathrm{oss}} \mathrm{h} / \mathrm{k}_{\mathrm{B}} \mathrm{T}\right)$ and $(1000 / \mathrm{T})$ across the temperature range of $21-80^{\circ} \mathrm{C}$. The reaction parameters are $\Delta \mathrm{H}^{\#}=16.8 \pm 0.5$ $\mathrm{kcal} / \mathrm{mol}$ and $\Delta \mathrm{S}^{\#}=-25 \pm 2 \mathrm{cal} / \mathrm{K} \mathrm{mol}$. 
Rate of benzene $\mathrm{C}(\mathrm{sp} 2)-\mathrm{H}$ exchange with TFE- $\mathrm{d}_{1}$ (Fig. S10)

General procedure A was followed except $\mathrm{C}_{6} \mathrm{H}_{6}$ was used instead of $\mathrm{C}_{6} \mathrm{D}_{6}$, and $\mathrm{CF}_{3} \mathrm{CH}_{2} \mathrm{OD}$ was used instead of $\mathrm{CF}_{3} \mathrm{CH}_{2} \mathrm{OH}$. To find the rate, the growth of the TFE -OH triplet was monitored. A control reaction with only 7 and $\mathrm{CF}_{3} \mathrm{CH}_{2} \mathrm{OD}$ showed negligible $\mathrm{H} / \mathrm{D}$ scrambling between the TFE - $\mathrm{CH}_{2}$ - and -OD.

Reaction at $80^{\circ} \mathrm{C}$
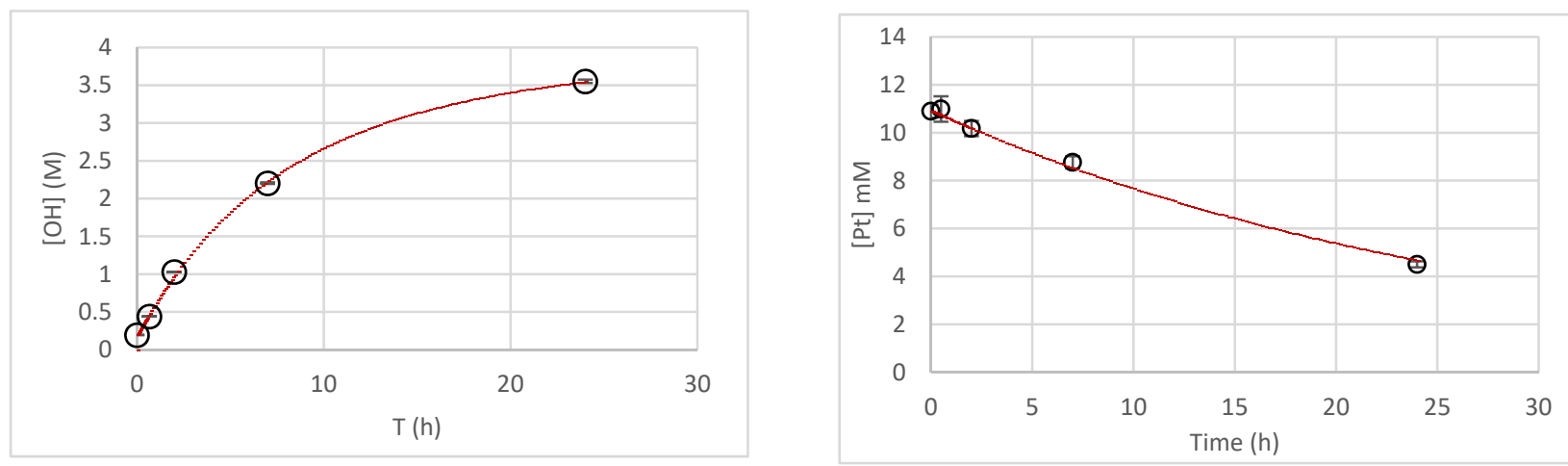

Figure S10. The reaction profiles for the $\mathrm{H} / \mathrm{D}$ exchange between benzene $(10 \mathrm{vol} . \%)-$ $\mathrm{CF}_{3} \mathrm{CH}_{2} \mathrm{OD}$ catalyzed by $13.1 \mathrm{mM} 7 \cdot 4 \mathrm{H}_{2} \mathrm{O}$ at $80^{\circ} \mathrm{C}$ (left) and consumption of 7 to form 17 (right). $\mathrm{k}_{1 \text { obs }}=1.89 \mathrm{E}-03 \pm 0.02 \times 10^{-3}\left(\mathrm{M}^{-1} \cdot \mathrm{s}^{-1}\right), \mathrm{k}_{2 \text { precip }}=0.27 \pm 0.05\left(\mathrm{M}^{-3} \cdot \mathrm{s}^{-3}\right), \mathrm{k}-2=0$ $\left(\mathrm{M} \cdot \mathrm{s}^{-1}\right)$.

\section{Deuterium Kinetic Isotope Effect}

The deuterium isotope effect was calculated by comparing the rate of exchange in $\mathrm{C}_{6} \mathrm{D}_{6} / \mathrm{CF}_{3} \mathrm{CH}_{2} \mathrm{OH}$ mixtures to that in $\mathrm{C}_{6} \mathrm{H}_{6} / \mathrm{CF}_{3} \mathrm{CH}_{2} \mathrm{OD}$ mixtures. Very similar values for the $\mathrm{KIE}$ were produced using the $k_{10 \mathrm{bs}, \mathrm{H}} / k_{10 \mathrm{bs}, \mathrm{D}}$ ratio or the initial rates, as shown in Table S5.

Table S5. KIE determined using $k_{10 b s}$ values and initial rates methods.

\begin{tabular}{|l|c|c|c|}
\hline & $\mathrm{k}_{1 \mathrm{obs}}, \mathrm{M}^{-1} \mathrm{~s}^{-1}$ & $k_{1 \mathrm{obs}, \mathrm{H}} / k_{1 \mathrm{obs}, \mathrm{D}}$ & Init. Rate $(\mathrm{H}) /$ Init. Rate $(\mathrm{D})$ \\
\hline $\mathrm{CH}$ Activation & 0.00189 & 1.49 & 1.67 \\
CD Activation & 0.00127 & & \\
\hline
\end{tabular}


Toluene, Xylene, and Mesitylene as Substrates for H/D Exchange

For Toluene:

General procedure A was followed except Toluene- $\mathrm{d}_{8}$ was used instead of $\mathrm{C}_{6} \mathrm{D}_{6}$ and the [Pt] was reduced to $6.57 \mathrm{mM}$. To find the rate of $\mathrm{H} / \mathrm{D}$ exchange the multiplets at $7.31 \mathrm{ppm}$ (meta C-D), $7.22 \mathrm{ppm}$ (ortho/para C-D), and $2.34 \mathrm{ppm}$ (benzyl C-D) were monitored. The TFE - $\mathrm{CH}_{2}$ - quartet was used as an internal standard. In each reaction, the TON at $0.5 \mathrm{~h}$ $(<2.0 \%$ conversion) was used to find the initial TOF which could be then be normalized for $\left[\mathrm{C}\left(\mathrm{sp}^{2}\right)-\mathrm{D}\right]$ to find the $\mathrm{k}_{1 \text { init }}$ (Table $\mathrm{S} 6$ ).

For xylene and mesitylene:

General procedure A was followed except $p$-xylene or mesitylene was used instead of $\mathrm{C}_{6} \mathrm{D}_{6}$, and TFE- $\mathrm{d}_{1}$ was used instead of TFE. The TFE-OH signal was used to monitor the rate of reaction while the solvent $-\mathrm{CH}_{2}$ - quartet was used as an internal standard. A control reaction with just complex 7 dissolved in TFE- $\mathrm{d}_{1}$ and heated to $80^{\circ} \mathrm{C}$ showed an initial TOF of $3.86 \pm 0.04 \times 10^{-4} \mathrm{~s}^{-1}$, primarily from $\mathrm{H} / \mathrm{D}$ exchange at the phenylene $\left(-\mathrm{C}_{6} \mathrm{H}_{4}-\right)$ portion of the ligand. The values presented below are corrected for this background reaction. To determine $\mathrm{C}\left(\mathrm{sp}^{2}\right)-\mathrm{H}$ vs $\mathrm{C}\left(\mathrm{sp}^{3}\right)-\mathrm{H}$ bond selectivity, the reactions were monitored for 2 days, at the end of which no detectable reduction in the $\mathrm{C}\left(\mathrm{sp}^{3}\right)-\mathrm{H}^{1} \mathrm{H}-\mathrm{NMR}$ peak was observed.

Table S6. H/D exchange rates for different (poly)methylbenzenes

\begin{tabular}{|c|c|c|c|}
\hline Substrate & {$[\mathrm{Pt}]_{\text {init }}(\mathrm{mM})$} & $\mathrm{TOF}_{\text {init }}\left(\mathrm{s}^{-1}\right)$ & $\mathrm{k}_{1 \text { init }}\left(\mathrm{M}^{-1} \cdot \mathrm{s}^{-1}\right)$ \\
\hline- & 13.1 & $3.86 \pm 0.04 \times 10^{-4}$ & - \\
$p-$ Xylene $_{\text {Mesitylene }}$ & 13.1 & $1.14 \pm 0.06 \times 10^{-3}$ & $3.5 \pm 0.2 \times 10^{-4}$ \\
Toluene-d8 $(-0,-p)$ & 13.1 & $3.3 \pm 0.1 \times 10^{-4}$ & $1.5 \pm 0.5 \times 10^{-4}$ \\
Toluene-d8 $(-m)$ & 13.1 & $1.2 \pm 0.2 \times 10^{-3}$ & $5.4 \pm 0.5 \times 10^{-4}$ \\
\hline
\end{tabular}

\section{Ortho/Meta/Para Selectivity in Tolune-d8}

In order to determine the selectivity between the ortho, meta, and para C-D bonds in Toluene- $d_{8}$, a standard H/D exchange experiment was run for only 10 minutes. All volatiles were then vacuum transferred into a clean NMR tube. The ${ }^{1} \mathrm{H}-\mathrm{NMR}$ spectrum of the reacted Tol-d $\mathrm{d}_{8} / \mathrm{TFE}$ solution was compared to that of unreacted Tol-d 8 /TFE and, using the toluene benzyl quintet as an internal standard set to 1.00, the ratios between ortho, meta, and para ${ }^{1} \mathrm{H}-\mathrm{NMR}$ peaks were found.

Table S7. Peak ratios before and after a short $H / D$ exchange reaction.

\begin{tabular}{|c|c|c|c|}
\hline Reaction Time (min) & $o-\mathrm{CH}$ Integration & $m-\mathrm{CH}$ Integration & $p$-CH Integration \\
\hline 0 & 0.7221 & 0.7405 & 0.3636 \\
10 & 0.7874 & 1.0627 & 0.5392 \\
\hline Difference & 0.0653 & 0.3222 & 0.1756 \\
\hline Normalized Ratio & $\mathbf{0 . 2}$ & $\mathbf{0 . 9}$ & $\mathbf{1 . 0}$ \\
\hline
\end{tabular}




\section{Using $\mathrm{K}\left[\left(\mathrm{C}_{6} \mathrm{H}_{4}-\mathrm{dpms}\right) \mathrm{PtCl}\right.$, Complex 9, as an $\mathrm{H} / \mathrm{D}$ Exchange Catalyst}

Complex $9(6.0 \mathrm{mg}, 33.7 \mu \mathrm{mol})$ was dissolved in $0.5 \mathrm{~mL} 10 \% \mathrm{v} / \mathrm{v}_{6} \mathrm{D}_{6} / \mathrm{TFE}$ to make a yellow solution. To this was added $1 \mu \mathrm{L}$ of a $\sim 50 \mathrm{wt} \% \mathrm{HBF}_{4}$ solution in $\mathrm{H}_{2} \mathrm{O}\left(\sim 1 \mathrm{eq}\right.$. $\left.\mathrm{HBF}_{4}\right)$. If no acid is added, only very slow H/D exchange is seen. The solution was transferred to an NMR Young tube equipped with a sealable Teflon cap and a sealed capillary tube containing $\mathrm{D}_{2} \mathrm{O}$. The NMR tube was then pressurized with $15 \mathrm{psi}$ argon. Due to the lower reactivity of 9 , the reaction was run at $120^{\circ} \mathrm{C}$. Care was taken to be sure no $\mathrm{LiCl}$ or $\mathrm{KCl}$ is present as $\mathrm{Cl}^{-}$salts were found to drastically diminish reactivity. No precipitate was observed over the course of the reaction. The reaction profile is shown in Fig. S11.

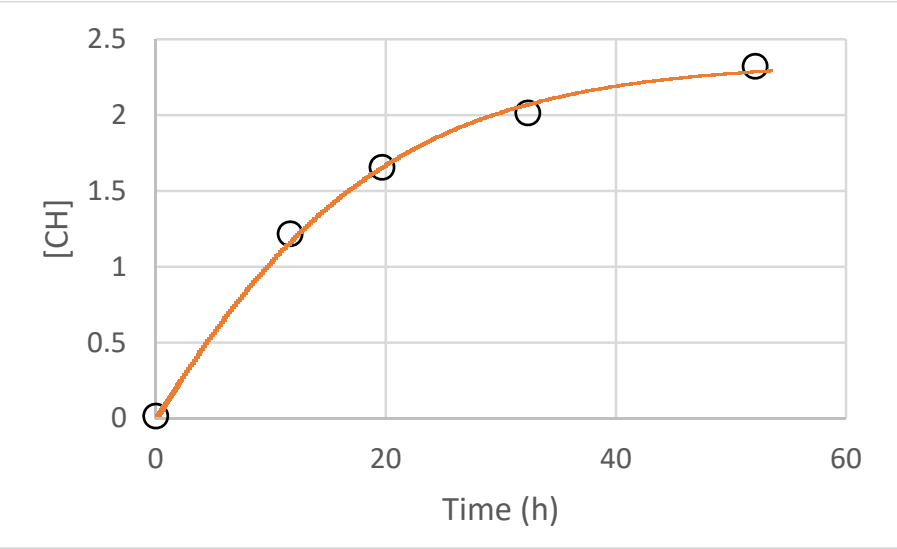

Figure S11. The reaction profile for the $H / D$ exchange between benzene- $d_{6}$ (10 vol. \%) $\mathrm{CF}_{3} \mathrm{CH}_{2} \mathrm{OH}$ catalyzed by $20.2 \mathrm{mM} 9$ at $120{ }^{\circ} \mathrm{C} ; \mathrm{HBF}_{4} \approx 20 \mathrm{mM}, \mathrm{H}_{2} \mathrm{O} \approx 80 \mathrm{mM}, \mathrm{k}_{1 \text { obs }}=2.5$ $\pm 0.1 \times 10^{-4}\left(\mathrm{M}^{-1} \cdot \mathrm{s}^{-1}\right)$.

Because the effect of $\mathrm{Cl}^{-}$salts was to diminish the $\mathrm{H} / \mathrm{D}$ exchange rate, we hypothesized that the formation of any LPt(solv) formed in the reaction of 9 with $\mathrm{H}^{+}$in TFE was being suppressed. A control experiment where 7 dissolved in TFE was combined with 1 equivalent of $\mathrm{KCl}$ exhibited a color change from orange to yellow in $<5$ min and only 9 was observed in the ${ }^{1} \mathrm{H}-\mathrm{NMR}$ spectrum (Scheme S2) despite the low solubility of $\mathrm{KCl}$ in TFE.

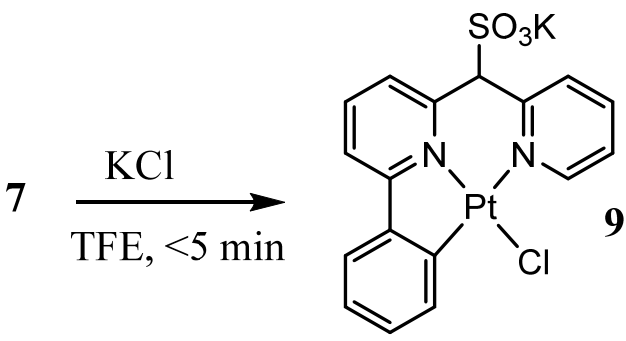

Scheme S2. The reaction of 7 with $\mathrm{KCl}$ in TFE produces 9 in less than five minutes.

\section{$\left[\mathrm{H}_{2} \mathrm{O}\right]$ effect on the rate of $\mathrm{H} / \mathrm{D}$ exchange}

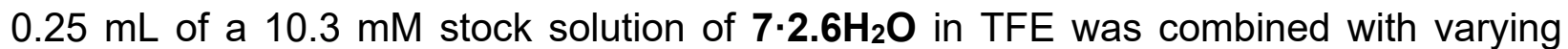
amounts of a $2.73 \mathrm{M}$ stock solution of $\mathrm{H}_{2} \mathrm{O}$ in TFE. Each solution was then diluted to 0.45 $\mathrm{mL}$ with pure TFE. To each was then added $0.05 \mathrm{~mL} \mathrm{C}_{6} \mathrm{D}_{6}$ to make a final volume of 0.50 
$\mathrm{mL}$ containing $10 \%$ by volume $\mathrm{C}_{6} \mathrm{D}_{6}$. The initial rate of $\mathrm{H} / \mathrm{D}$ exchange at $80{ }^{\circ} \mathrm{C}$ was found by analyzing the TOF over the first hour of reaction ( $<5 \%$ conversion). The initial rate fell gradually as the $\left[\mathrm{H}_{2} \mathrm{O}\right] /[\mathrm{TFE}]$ ratio increased (Fig. S12).

Table S8. Solution composition and $\mathrm{H} / \mathrm{D}$ exchange rates to find $\left[\mathrm{H}_{2} \mathrm{O}\right]$ effect.

\begin{tabular}{|l|c|c|c|c|c|}
\hline & Solution & {$[\mathrm{H} 2 \mathrm{O}]$ tot } & {$[\mathrm{TFE}](\mathrm{M})$} & {$[\mathrm{Pt}](\mathrm{mM})$} & Init. Rate (M/h) \\
\hline Low H2O & $\mathrm{A}$ & 0.038 & 12.44 & 5.14 & $0.178 \pm 0.003$ \\
& $\mathrm{~B}$ & 0.110 & 12.43 & 5.14 & $0.174 \pm 0.003$ \\
& $\mathrm{C}$ & 0.275 & 12.39 & 5.14 & $0.131 \pm 0.001$ \\
& $\mathrm{D}$ & 0.477 & 12.33 & 5.14 & $0.097 \pm 0.001$ \\
& $\mathrm{E}$ & 0.765 & 12.27 & 5.14 & $0.073 \pm 0.001$ \\
High H2O & $\mathrm{F}$ & 1.16 & 12.20 & 5.14 & $0.060 \pm 0.002$ \\
\hline
\end{tabular}

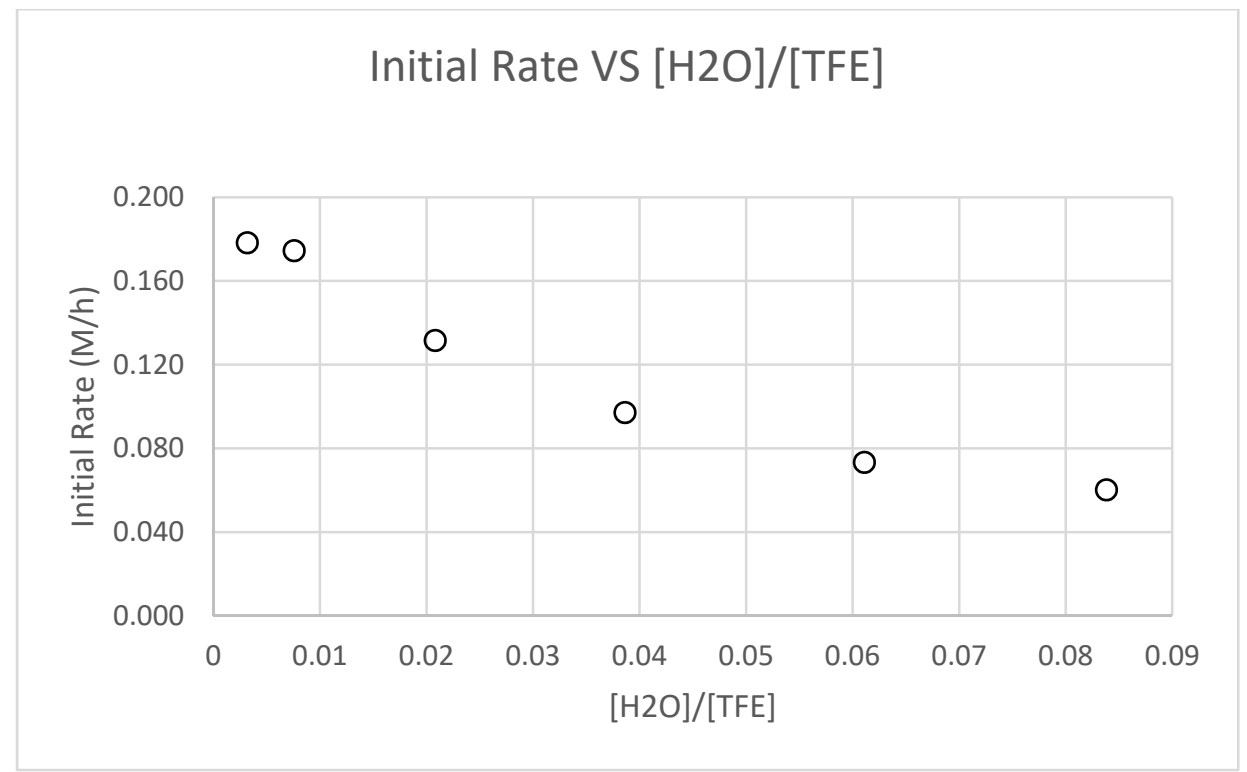

Figure S12. Dependence of the initial rate of $\mathrm{H} / \mathrm{D}$ exchange between $\mathrm{C}_{6} \mathrm{D}_{6}$ and $\mathrm{CF}_{3} \mathrm{CH}_{2} \mathrm{OH}$ at $80^{\circ} \mathrm{C}$ on the $\left[\mathrm{H}_{2} \mathrm{O}\right] /[\mathrm{TFE}]$ ratio. 
The H/D exchange kinetics models

A. Derivation of the rate law (eq 3 in the manuscript) for a simplified reaction scheme (Scheme 6 in the manuscript)

$$
\mathrm{Ph}-\mathrm{D}+\mathrm{LPt} \text { (solv) }
$$

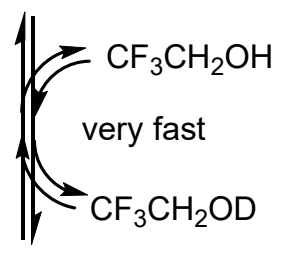

Let's designate and

$$
\left[\mathrm{LPt}^{\mathrm{IV}}\right]=\left[\mathrm{LPt}^{\mathrm{IV}}(\mathrm{Ph}) \mathrm{D}\right]+\left[\mathrm{LPt}^{\mathrm{IV}}(\mathrm{Ph}) \mathrm{H}\right]
$$

$$
b=\frac{[R O D]}{[R O D]+[R O H]}
$$

Assuming a statistical $H / D$ distribution at $\mathrm{Pt}^{\mathrm{IV}}$, we get:

$$
\left[L P t^{I V}(\mathrm{Ph}) \mathrm{D}\right]=\frac{[R O D]}{[R O D]+[R O H]}\left[L P t^{I V}\right]
$$

The actual distribution may be slightly different by a factor of EIE (equilibrium $\mathrm{H} / \mathrm{D}$ isotope effect). That difference will produce some error and contribute to the $k_{-1}^{H} / k_{-1}^{D}$ ratio. In the analysis below we assume that $E I E=1$.

The rate law for the overall $H / D$ exchange reaction in Scheme 6 can be written as:

$$
\begin{aligned}
& \text { (1S ) }-\frac{d[C D]}{d t}=k_{1 o b s, D}[C-D][L P t(\text { solv })]-k_{-1 o b s, D} b[\operatorname{solv}]\left[L P t^{I V}\right]= \\
& =\frac{d[C H]}{d t}=-k_{1 o b s, H}[C-H][L P t(s o l v)]-k_{-1 o b s, H}(1-b)[\operatorname{solv}]\left[L P t^{I V}\right]
\end{aligned}
$$

Use steady state approximation for [ $\left.\mathrm{LPt}^{\mathrm{IV}}\right]$ :

$\frac{d\left[L P t^{I V}\right]}{d t}=k_{1 o b s, D}[C-D][L P t(s o l v)]-k_{-1 o b s, D} b[\operatorname{solv}]\left[L P t^{I V}\right]+k_{1 o b s, H}[C-$

$H][\operatorname{LPt}(\mathrm{solv})]-k_{-1 o b s, H}(1-b)[\operatorname{solv}]\left[L P t^{I V}\right]=0$

Which gives:

(2S) $\left[L P t^{I V}\right]=\frac{\left(k_{1 o b s, D}[C-D]+k_{10 b s, H}[C-H]\right)}{k_{-10 b s, D} b+k_{-1 o b s, H}(1-b)} \frac{[L P t(s o l v)]}{[s o l v]}$

Substitute (2S) into (1S):

$\frac{d[C H]}{d t}=k_{1 o b s, D}[C-D][L P t(s o l v)]-k_{-1 o b s, D} b \frac{\left(k_{1 o b s, D}[C-D]+k_{1 o b s, H}[C-H]\right)}{k_{-1 o b s, D} b+k_{-1 o b s, H}(1-b)}[\operatorname{LPt}($ solv $)]$

which is equivalent to 
( 3S ) $\frac{d[C H]}{d t}=\frac{\left.k_{1 o b s, D}[C-D] k_{-1 o b s, H}(1-b)-k_{1 o b s, H}[C-H]\right) k_{-1 o b s, D} b}{k_{-1 o b s, D} b+k_{-1 o b s, H}(1-b)}[\operatorname{LPt}(\operatorname{solv})]$

If we designate $\left.k_{-1 o b s, H}\right|_{k_{-1 o b s, D}}=I E-$ deuterium kinetic isotope effect for the $\mathrm{C}-\mathrm{H}$ bond reductive elimination from $\mathrm{Pt}^{\mathrm{IV}}$, we can transform (3S) as follows:

(4S ) $\frac{d[C H]}{d t}=\frac{\left.k_{1 o b s, D}[C-D] I E(1-b)-k_{1 o b s, H}[C-H]\right) b}{b+I E(1-b)}[\operatorname{LPt}(\operatorname{solv})]$

By fitting experimental kinetics data one can find $k_{1 \mathrm{obs}, \mathrm{D}}, k_{1 \mathrm{obs}, \mathrm{H}}$ and $I E$.

Using an assumption, $I E=1$, we can transform (4S) into the equation (4) provided in the manuscript. 
B. Derivation of the rate law (eq 4 in the manuscript) using a more detailed reaction scheme (Scheme 8 in the manuscript)

$$
\begin{array}{ccc}
(\mathrm{L}) \mathrm{Pt}\left(\mathrm{OH}_{2}\right)+\mathrm{CF}_{3} \mathrm{CH}_{2} \mathrm{OH} & \stackrel{K_{\text {TFE }}}{\text { fast }} & (\mathrm{L}) \mathrm{Pt}(\mathrm{TFE})+\mathrm{H}_{2} \mathrm{O} \\
k_{-1, \mathrm{H} 2 \mathrm{O}} \| \begin{array}{l}
+\mathrm{C}_{6} \mathrm{D}_{6} \\
k_{1, \mathrm{H} 2 \mathrm{O}}
\end{array} & k_{-1, \text { TFE }} \| \begin{array}{l}
+\mathrm{C}_{6} \mathrm{D}_{6} \\
k_{1, \text { TFE }}
\end{array} \\
(\mathrm{L}) \mathrm{Pt}(\sigma-\mathrm{PhD})+\mathrm{H}_{2} \mathrm{O} & (\mathrm{L}) \mathrm{Pt}(\sigma-\mathrm{PhD})+\mathrm{TFE} \\
(\mathrm{L}) \mathrm{Pt}(\sigma-\mathrm{PhD}) \stackrel{k_{2}}{\rightleftharpoons} \quad(\mathrm{L}) \mathrm{Pt}(\mathrm{Ph}) \mathrm{D} & \longrightarrow \begin{array}{c}
\text { H/D exchange with } \mathrm{ROH} \\
\text { and elimination of } \mathrm{PhH}
\end{array}
\end{array}
$$

Considering the initial reaction period when one can neglect the contribution of the reverse reaction ( $k-2$ in the Scheme above) and when the expected reaction product is $\mathrm{C}_{6} \mathrm{D}_{5} \mathrm{H}$, we can write:

$$
-\frac{d[C D]}{d t}=k_{2}[\operatorname{LPt}(P h D)]
$$

Use steady-state approximation for [LPt(PhD)]:

$$
\begin{aligned}
\frac{d[\operatorname{LPt}(P h D)]}{d t} & =k_{1, T F E}[\operatorname{LPt}(T F E)][P h D]+k_{1, H 2 O}[\operatorname{LPt}(H 2 O)][P h D]-k_{-1, T F E}[\operatorname{LPt}(\operatorname{PhD})][T F E] \\
& -k_{-1, H 2 O}[\operatorname{LPt}(P h D)][H 2 O]-k_{2}[\operatorname{LPt}(P h D)]=0
\end{aligned}
$$

Which gives

$$
[\operatorname{LPt}(P h D)]=\frac{k_{1, T F E}[\operatorname{LPt}(\mathrm{TFE})]+k_{1, H 2 O}[\operatorname{LPt}(\mathrm{H} 2 O)]}{k_{-1, T F E}[T F E]+k_{-1, H 2 O}[H 2 O]+k_{2}}[P h D]
$$

Finally, by substituting (6S) into (5S), we get the rate law:

$$
-\frac{d[C D]}{d t}=k_{2} \frac{k_{1, T F E}[L P t(T F E)]+k_{1, H 2 O}[L P t(H 2 O)]}{k_{-1, T F E}[T F E]+k_{-1, H 2 O}[H 2 O]+k_{2}}[P h D]
$$

This can be re-written as

$$
-\frac{d[C D]}{d t}=\frac{k_{1, H 2 O}[L P t(H 2 O)]+k_{1, T F E}[L P t(T F E)]}{\left(k_{-1, H 2 O} / k_{2}\right)[H 2 O]+\left(k_{-1, T F E} / k_{2}\right)[T F E]+1}[P h D]
$$

Then using the experimentally determined initial reaction rates and associated [LPt(TFE)], [ $\left.\mathrm{LPt}\left(\mathrm{H}_{2} \mathrm{O}\right)\right]$, [TFE] and [ $\mathrm{H}_{2} \mathrm{O}$ ] one can find four parameters present in (8S),

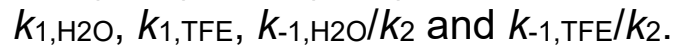

\section{Analysis of the parameters above can be carried out as follows}

If the parameter $k_{-1, \mathrm{H}_{2} \mathrm{O} / k_{2}}$ is more than 1 , the aqua complex $\mathrm{LPt}\left(\mathrm{H}_{2} \mathrm{O}\right)$ reacts via rate-

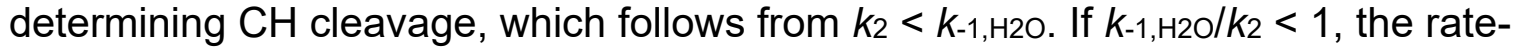
determining step for this complex is the ligand exchange.

Similarly, if the ratio $k_{-1, T F E} / k_{2}$ is more than 1 , then the TFE complex LPt(TFE) reacts via rate-determining $\mathrm{CH}$ cleavage, which follows from $k_{2}<k-1$, TFE. If $k-1$, TFE $/ k_{2}<1$, the ratedetermining step for this complex is the ligand exchange. 


\section{Effect of water additives on the $C_{6} D_{6}-$ TFE H/D exchange: using the detailed reaction model.}

Using $5.15 \mathrm{mM}$ TFE solutions of 7 containing 10 vol. $\% \mathrm{C}_{6} \mathrm{D}_{6}\left(\left[\mathrm{C}_{6} \mathrm{D}_{6}\right]=1.13 \mathrm{M}\right)$ with variable concentration of water verified by ${ }^{1} \mathrm{H}$ NMR integration of the water signal in $\mathrm{TFE}$, we obtained the following initial reaction rates at $80^{\circ} \mathrm{C}$ :

Table S9. [ $\mathrm{H}_{2} \mathrm{O}$ ], Complex ratio and initial rates used for fitting the detailed reaction model.

\begin{tabular}{|c|c|c|}
\hline$\left[\mathrm{H}_{2} \mathrm{O}\right], \mathrm{M}$ & {$[\mathrm{LPt}(\mathrm{TFE})] /\left[\mathrm{LPt}\left(\mathrm{H}_{2} \mathrm{O}\right)\right]$} & Initial rate, $\mathrm{M} \mathrm{h}^{-1}$ \\
\hline 0.038 & 3.71 & $0.178 \pm 0.003$ \\
\hline 0.110 & 1.77 & $0.174 \pm 0.003$ \\
\hline 0.275 & 0.454 & $0.132 \pm 0.001$ \\
\hline 0.477 & 0.171 & $0.097 \pm 0.001$ \\
\hline 0.765 & 0.065 & $0.073 \pm 0.001$ \\
\hline 1.16 & 0.029 & $0.060 \pm 0.002$ \\
\hline
\end{tabular}

Using the equation (8S) above and non-linear least squares regression analysis an accurate fit was produced with the average point deviation $3.47 \%$ vs. maximum reaction rate (Fig. S13).

The most important reaction parameter value that was found is $k_{-1, \mathrm{TFE}} / k_{2}=3.8 \times 10^{-5}$. Since the $k_{-1}$,TFE/ $k 2$ value is less than $1, \operatorname{LPt}(\mathrm{TFE})$ reacts with benzene via a ratedetermining ligand exchange. Since the rate law (8S) was deduced including only reaction channels corresponding to the rate-determining $\mathrm{CH}$ bond cleavage, the $k_{1, T F E}[L P t(T F E)]$ term was next excluded from equ (8S) and the fitting procedure repeated resulting in $k_{1, \mathrm{H} 2 \mathrm{O}}=8.67 \times 10^{-2} \mathrm{M}^{-1} \mathrm{~s}^{-1}$ (the ligand exchange activation energy

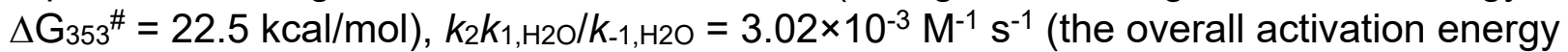

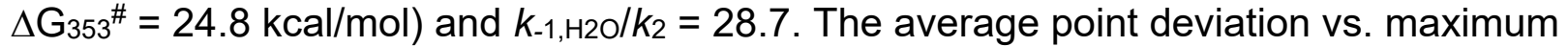
reaction rate was $5.35 \%$.

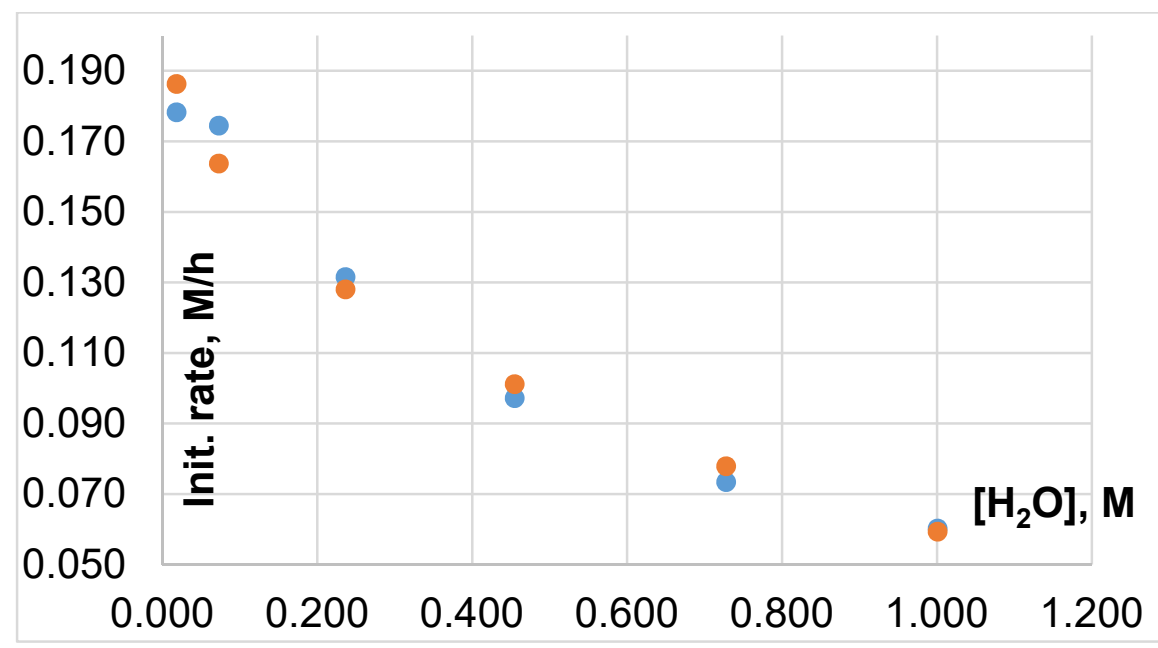

Figure S13. Experimental (blue circles) vs. calculated using eq. 8S (orange circles) initial reaction rates in the system $\mathrm{H}_{2} \mathrm{O}-\mathrm{CF}_{3} \mathrm{CH}_{2} \mathrm{OH}$ - benzene-d6 (10\% vol.) - complex $7(0.00515 \mathrm{M})$ at $80^{\circ} \mathrm{C}$. 


\section{Oxidation of Complex 7 in TFE Solutions}

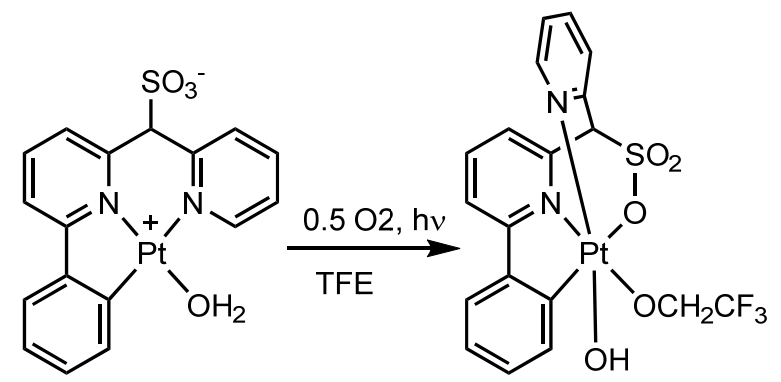

$\left(\mathrm{C}_{6} \mathrm{H}_{4}\right.$-dpms $) \mathrm{Pt}\left(\mathrm{OH}_{2}\right), 7 \quad\left(\mathrm{C}_{6} \mathrm{H}_{4}\right.$-dpms $) \mathrm{Pt}\left(\mathrm{OCH}_{2} \mathrm{CF}_{3}\right)(\mathrm{OH}), 15$

Only the reactions run under ambient fluorescent lighting showed oxidation of 7 to 15. To a $25 \mathrm{~mL}$ Schlenk tube was added $\mathbf{7} \cdot \mathbf{4} \mathrm{H}_{2} \mathrm{O}(40 \mathrm{mg}, 66 \mu \mathrm{mol})$ dissolved in $5 \mathrm{~mL}$ TFE. A stir bar was added followed by purging of its headspace with $\mathrm{O}_{2}$ and pressurization to 20 psi $\mathrm{O}_{2}$ before being sealed. The solution was stirred vigorously at room temperature over the course of five days. The color initially changed to red and then slowly turned yellow. A 0.5 $\mathrm{mL}$ aliquot was removed and submitted to a ${ }^{1} \mathrm{H}-\mathrm{NMR}$ analysis in DMSO-d6 which showed one new species, identified as complex 15 (vide infra) in a 0.7:1 ratio with $\left(\mathrm{C}_{6} \mathrm{H}_{4}-\right.$ dpms)Pt(DMSO-d6) (41\% NMR yield of 15). The TFE solution was dried in vacuo to yield a light yellow residue which was extracted with $3 \times 1 \mathrm{~mL} \mathrm{MeOH}$. The $\mathrm{MeOH}$ was removed to yield $19 \mathrm{mg}$ of an off-white powder. The powder was dissolved in $0.5 \mathrm{~mL}$ TFE, layered with $\mathrm{Et}_{2} \mathrm{O}$, and placed in the freezer. The next day small thin needle crystals suitable for XRD analysis had formed. The structure of 15 in DMSO-d6 solution was additionally confirmed by ${ }^{1} \mathrm{H}-{ }^{1} \mathrm{H}$ COSY and ${ }^{1} \mathrm{H}$ NOE NMR experiments and was found to be consistent with the observed crystal structure. Samples of complex 15 are stable when stored in the freezer but slowly decompose at room temperature over the course of a few days.

${ }^{1} \mathrm{H}$ NMR (400 MHz, $22{ }^{\circ} \mathrm{C}$, DMSO-d6), $\delta: 1.53(\mathrm{~s}, 1 \mathrm{H}), 3.77\left(\mathrm{dq},{ }^{2} \mathrm{~J}_{\mathrm{HH}}=12.7 \mathrm{~Hz},{ }^{3} J_{\mathrm{HF}}=\right.$ $10.1 \mathrm{~Hz}, 1 \mathrm{H}), 4.01\left(\mathrm{dq},{ }^{2} J_{\mathrm{HH}}=12.7 \mathrm{~Hz},{ }^{3} J_{\mathrm{HF}}=10.1 \mathrm{~Hz}, 1 \mathrm{H}\right), 6.88(\mathrm{~s}, 1 \mathrm{H}), 7.35(\mathrm{~m}, 2 \mathrm{H})$, $7.62(\mathrm{~m}, 1 \mathrm{H}), 7.78\left(\mathrm{ddd},{ }^{3} \mathrm{~J}_{\mathrm{HH}}=8.1,5.8 \mathrm{~Hz},{ }^{4} \mathrm{~J}_{\mathrm{HH}}=1.3 \mathrm{~Hz}, 1 \mathrm{H}\right), 7.86\left(\mathrm{dd},{ }^{3} \mathrm{~J}_{\mathrm{HH}}=7.2 \mathrm{~Hz}\right.$, $\left.{ }^{4} J_{\mathrm{HH}}=1.4 \mathrm{~Hz}, 1 \mathrm{H}\right), 7.90(\mathrm{~m}, 1 \mathrm{H}), 8.01\left(\mathrm{dd},{ }^{3} \mathrm{~J}_{\mathrm{HH}}=8.0 \mathrm{~Hz},{ }^{4} J_{\mathrm{HH}}=0.7 \mathrm{~Hz}, 1 \mathrm{H}\right), 8.23-8.32$ $(\mathrm{m}, 3 \mathrm{H}), 8.67\left(\mathrm{dd},{ }^{3} \mathrm{~J}_{\mathrm{HH}}=5.9 \mathrm{~Hz},{ }^{4} \mathrm{~J}_{\mathrm{HH}}=1.5 \mathrm{~Hz}, 1 \mathrm{H}\right)$.

${ }^{19} \mathrm{~F}$ NMR (376 MHz, $\left.21^{\circ} \mathrm{C}, \mathrm{DMSO}-\mathrm{d}_{6}\right), \delta:-73.49\left(\mathrm{bt},{ }^{3} \mathrm{~J}_{\mathrm{HF}}=10.1 \mathrm{~Hz}\right)$

ESI-MS of solution of 15 in TFE, $[15-\mathrm{H}]^{-}=633.98$. Calculated for $[15-\mathrm{H}]^{-}$ $\mathrm{C}_{19} \mathrm{H}_{16} \mathrm{~F}_{3} \mathrm{~N}_{2} \mathrm{O}_{5} \mathrm{PtS}^{-}, 634.02$.

The oxidation of 7 dissolved in TFE was monitored by ${ }^{1} \mathrm{H}-\mathrm{NMR}$ spectroscopy. Complex $\mathbf{7} \cdot \mathbf{4} \mathrm{H}_{2} \mathrm{O}(4.0 \mathrm{mg}, 6.7 \mu \mathrm{mol})$ was dissolved in $0.5 \mathrm{~mL}$ TFE and transferred to an NMR Young tube equipped with a sealable Teflon cap. After taking an initial NMR spectrum, the headspace was flushed with dry $\mathrm{O}_{2}$ and then pressurized to 20 psi with additional $\mathrm{O}_{2}$ (35 $\mathrm{psi} \mathrm{pO}_{2}$ total). The NMR tube was then placed on a rotator to insure adequate $\mathrm{O}_{2}$ /solution mixing. The disappearance of the starting material 7 was monitored 
using signals of the solvent as an internal standard resulting in the reaction profile shown below. The rate was found to follow a second order rate law (Figure S14).

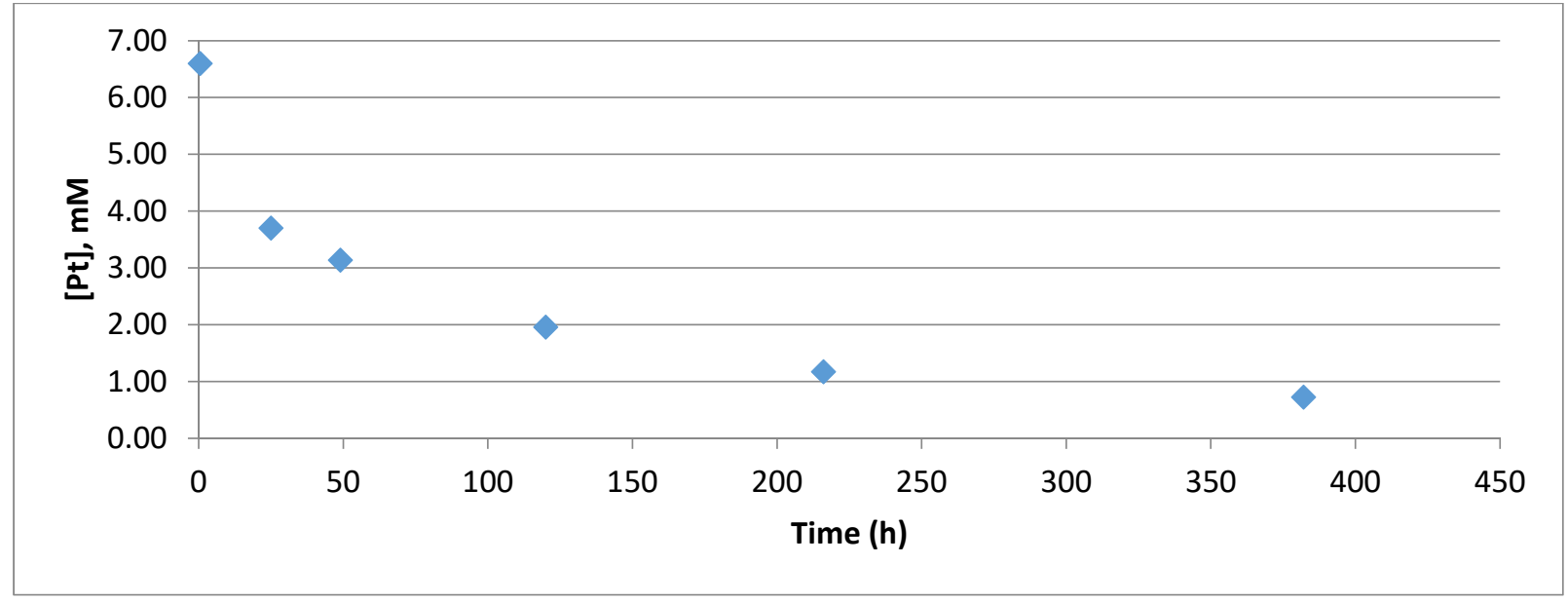

a) Reaction profile for the oxidation of 7 in TFE under $35 \mathrm{psi}^{\mathrm{pO}} 2$.

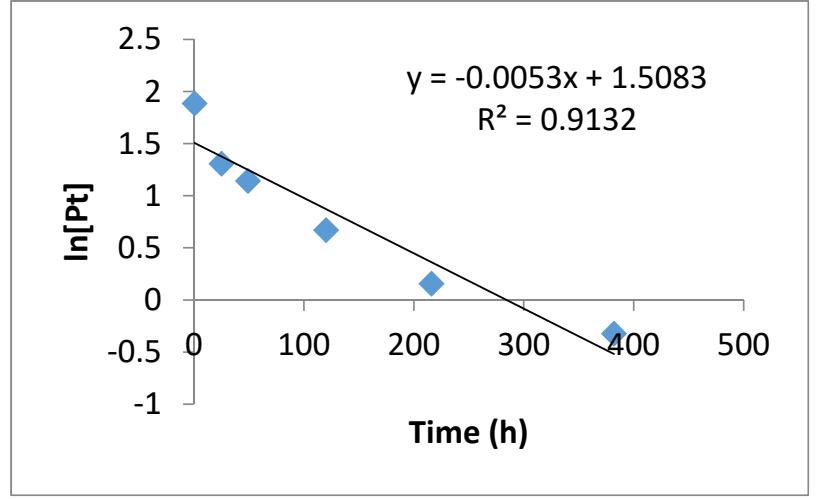

b) Attempted first order fitting.

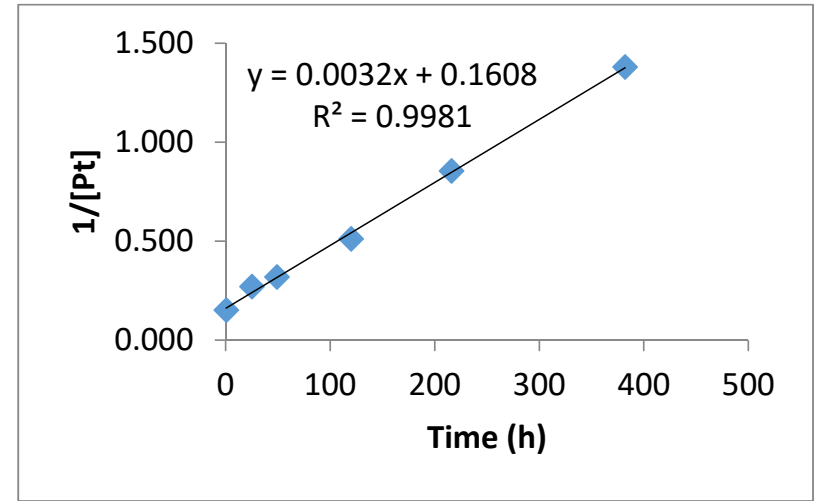

c) Second order fitting.

Figure S14. a) Reaction profile for the oxidation of 7 in TFE. b) Attempted first order fitting. c) Second order fitting. 


\section{NMR Spectra}

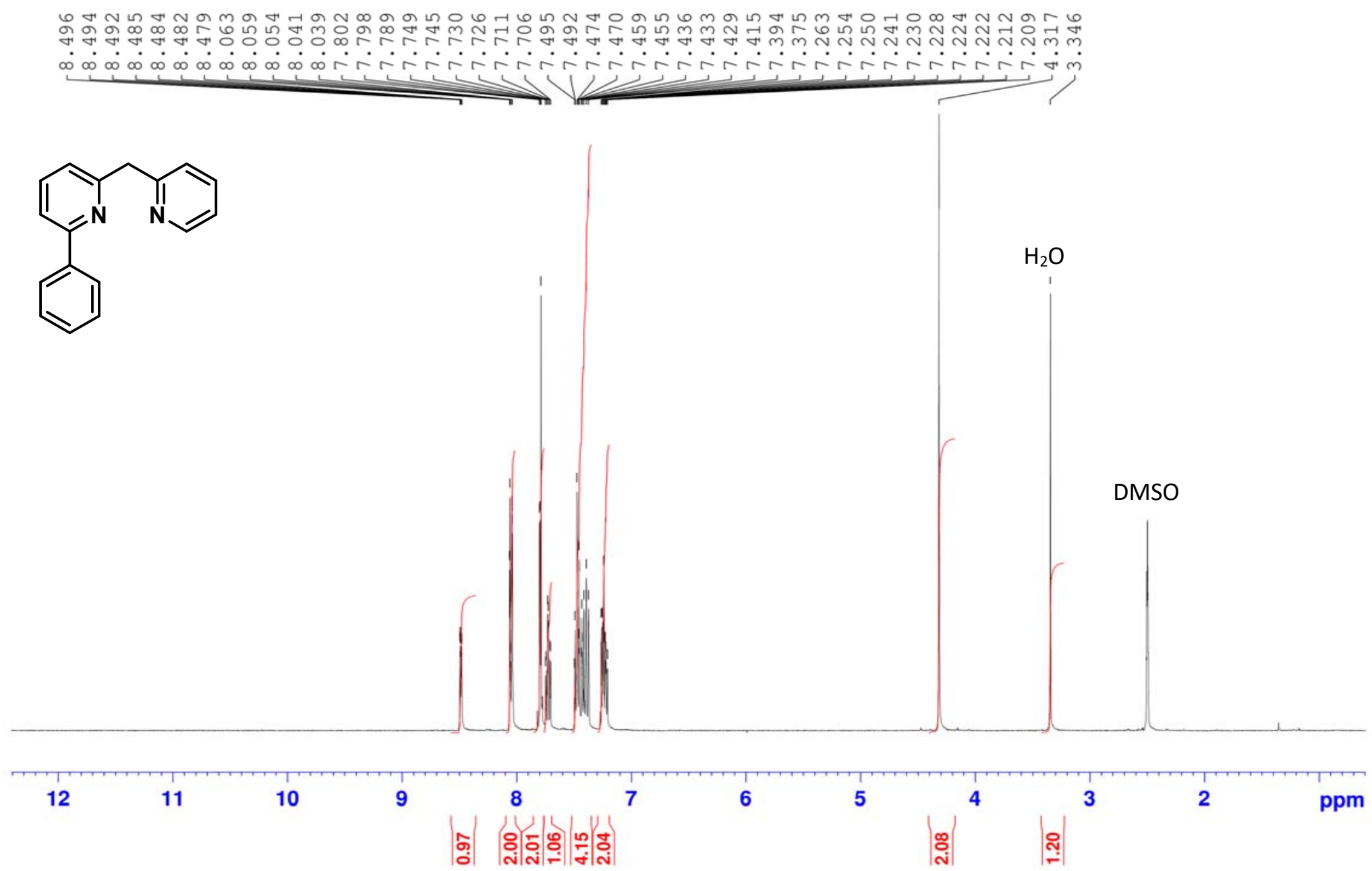

Figure S15. ${ }^{1} \mathrm{H}$ NMR of (6-phenylpyrid-2-yl)(2-pyridyl)methane, S2, in DMSO-d 6 . 

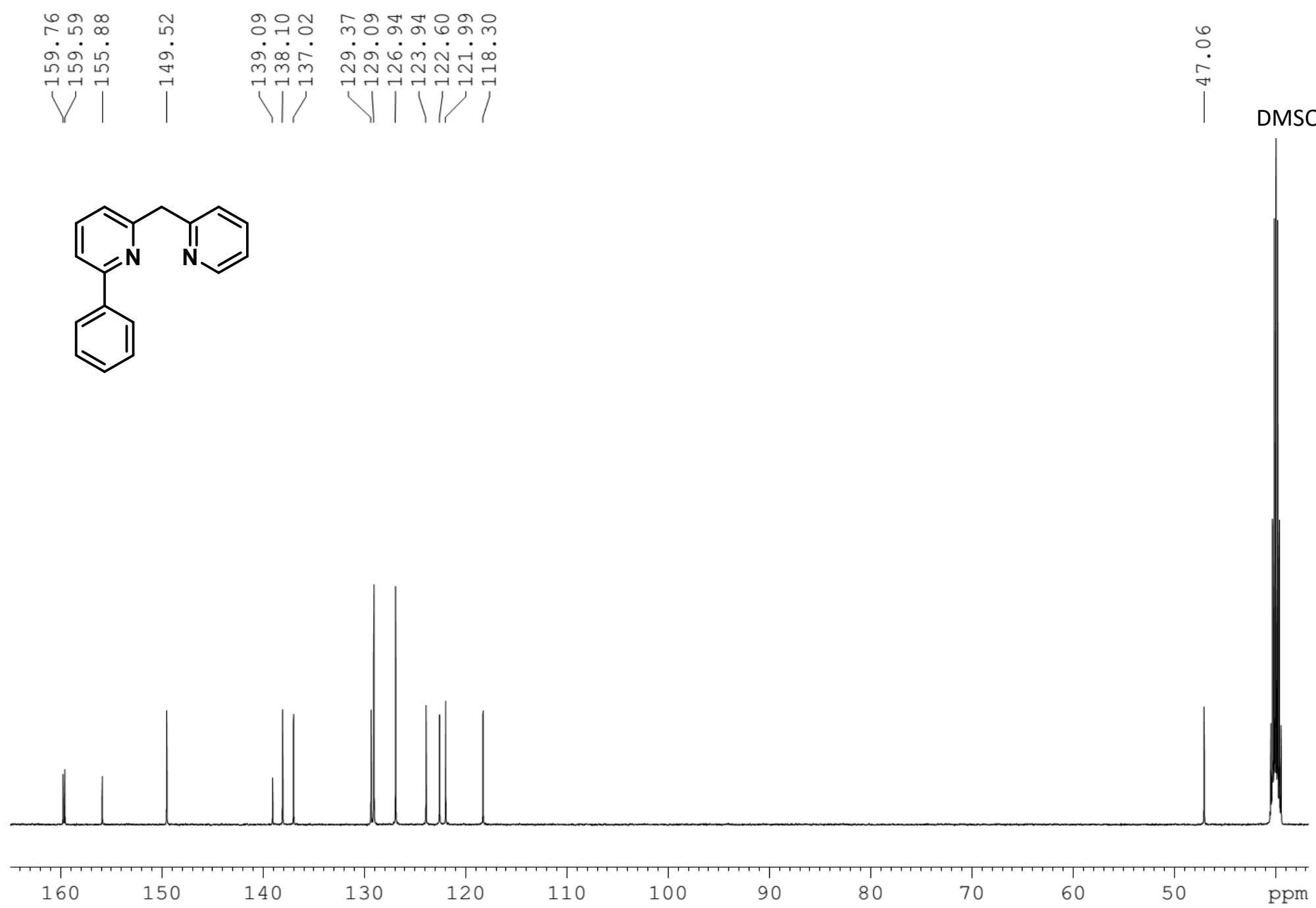

Figure S16. ${ }^{13} \mathrm{C}$ NMR of (6-phenylpyrid-2-yl)(2-pyridyl)methane, $\mathbf{S 2}$, in DMSO-d 6 


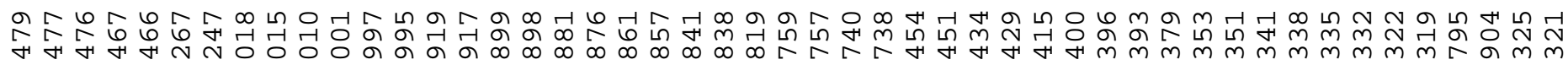

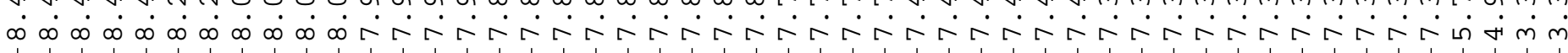

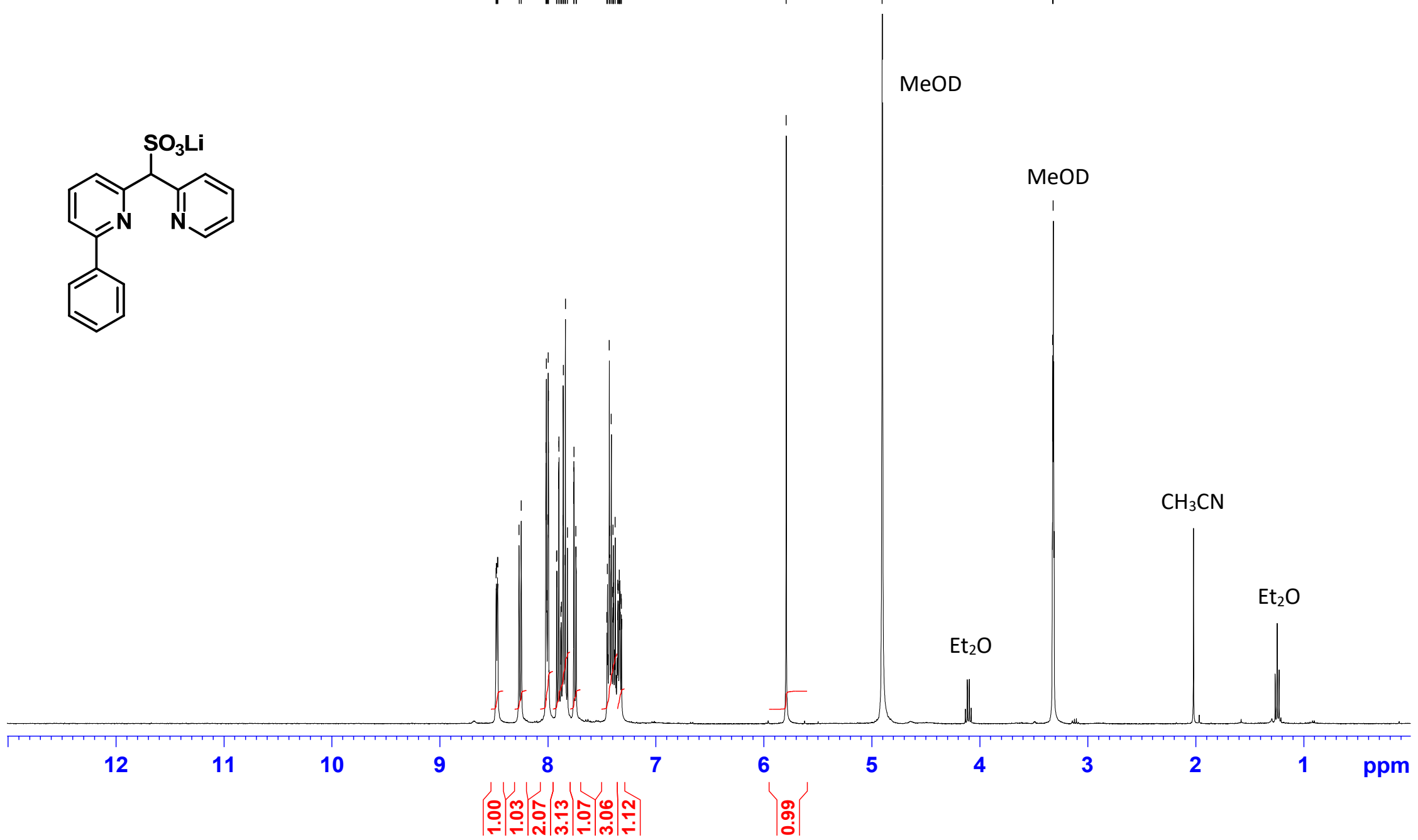

Figure S17. ${ }^{1} \mathrm{H}$ NMR of $\mathrm{Li}(\mathrm{Ph}-\mathrm{dpms})$ in MeOD. 


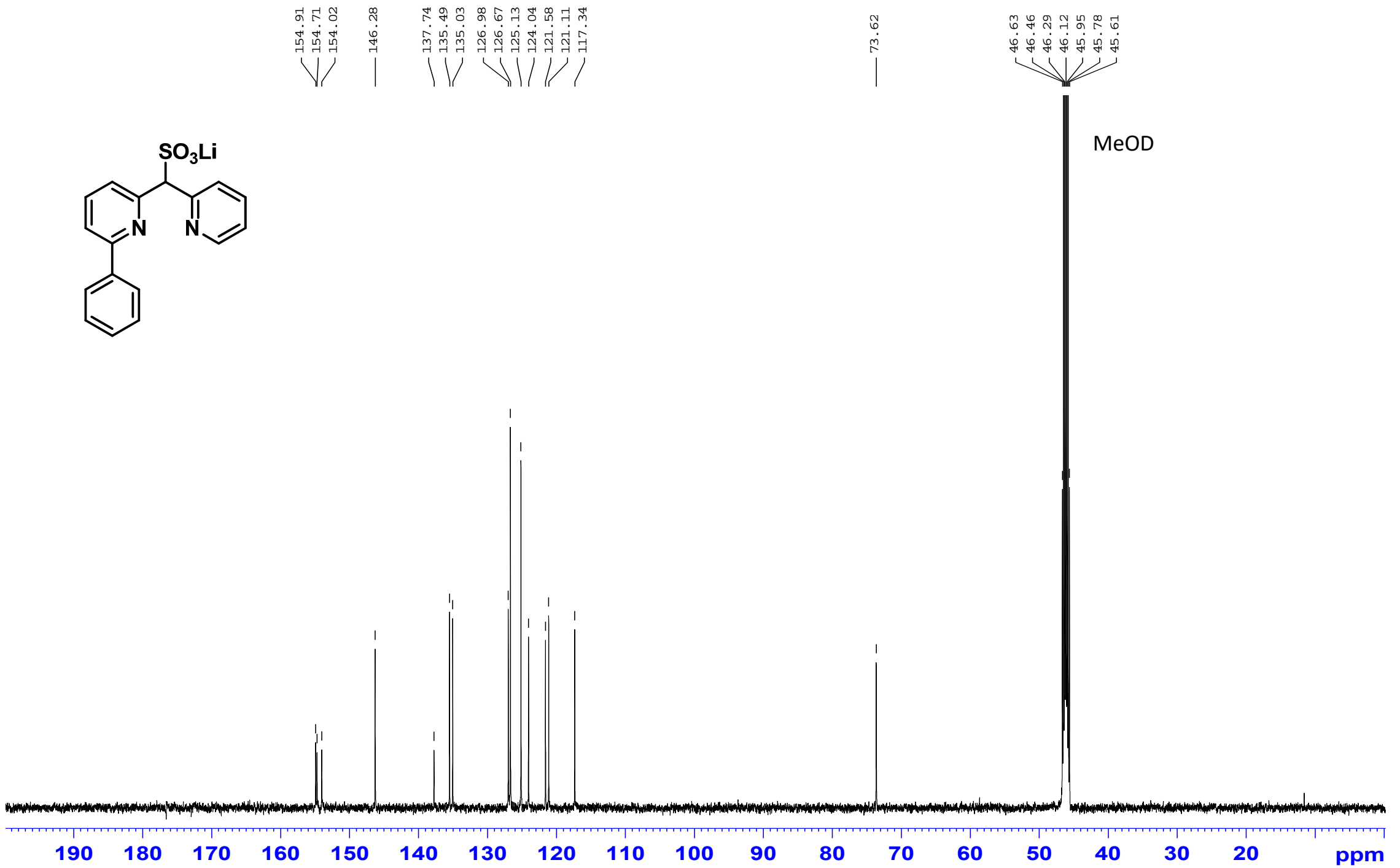

Figure S18. ${ }^{13} \mathrm{C}$ NMR of Li(Ph-dpms) in MeOD. 


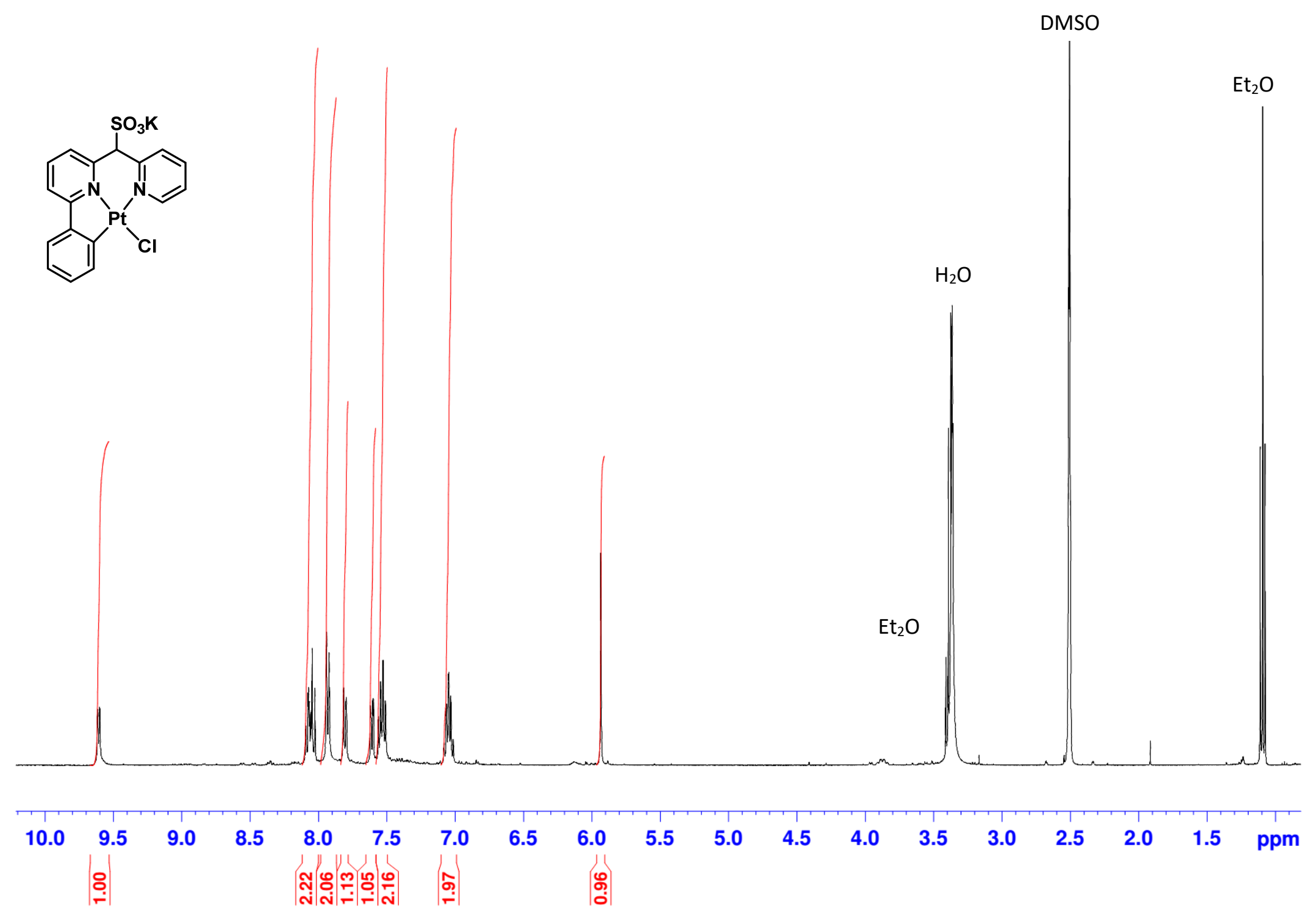

Figure S19. ${ }^{1} \mathrm{H}$ NMR of $\mathrm{K}\left[\left(\mathrm{C}_{6} \mathrm{H}_{4}-\mathrm{dpms}\right) \mathrm{PtCl}\right]$, 9, in DMSO- $\mathrm{d}_{6}$ 


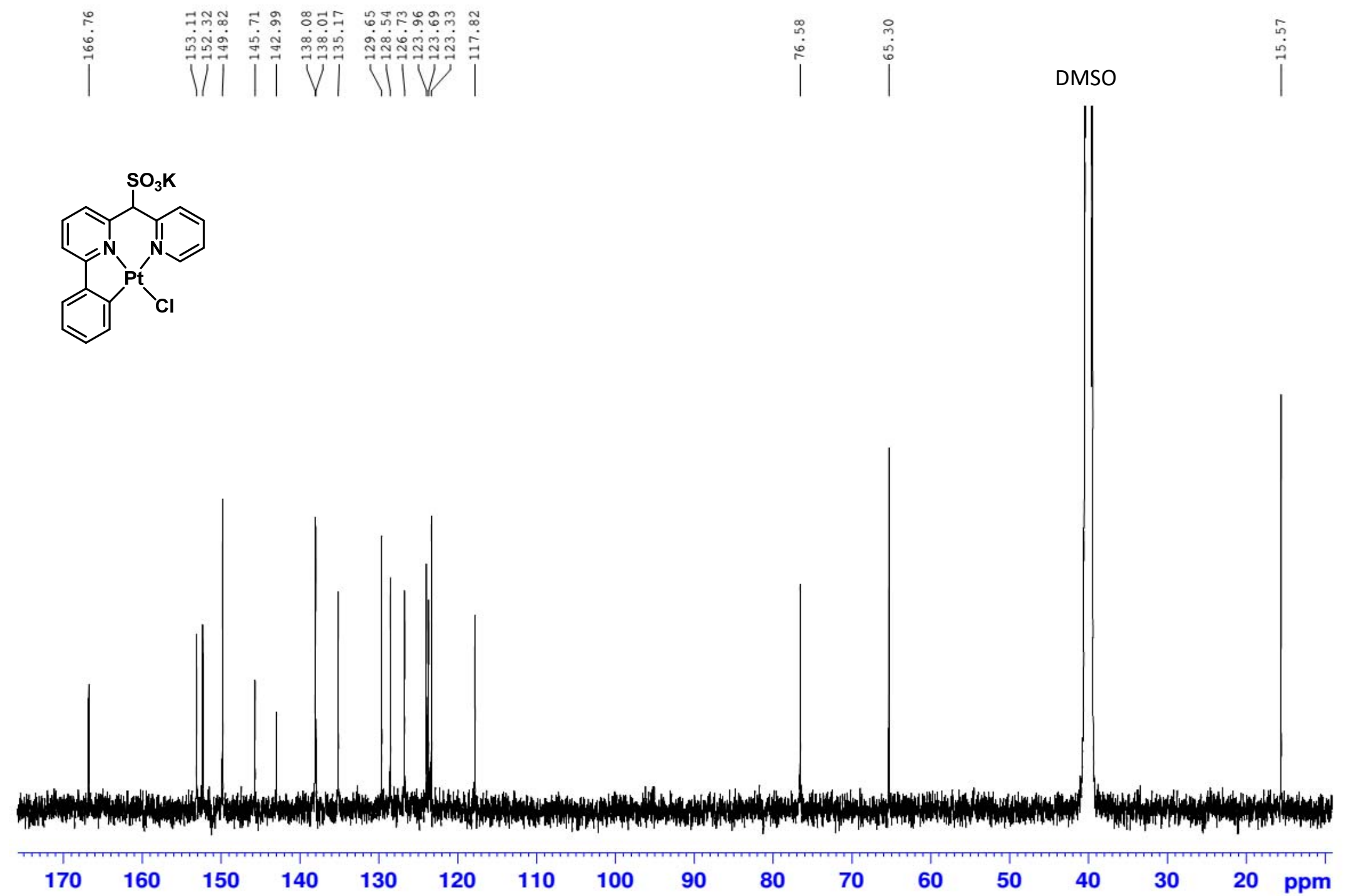

Figure S20. ${ }^{13} \mathrm{C}$ NMR of $\mathrm{K}\left[\left(\mathrm{C}_{6} \mathrm{H}_{4}-\mathrm{dpms}\right) \mathrm{PtCl}\right]$, 9, in DMSO- $\mathrm{d}_{6}$ 

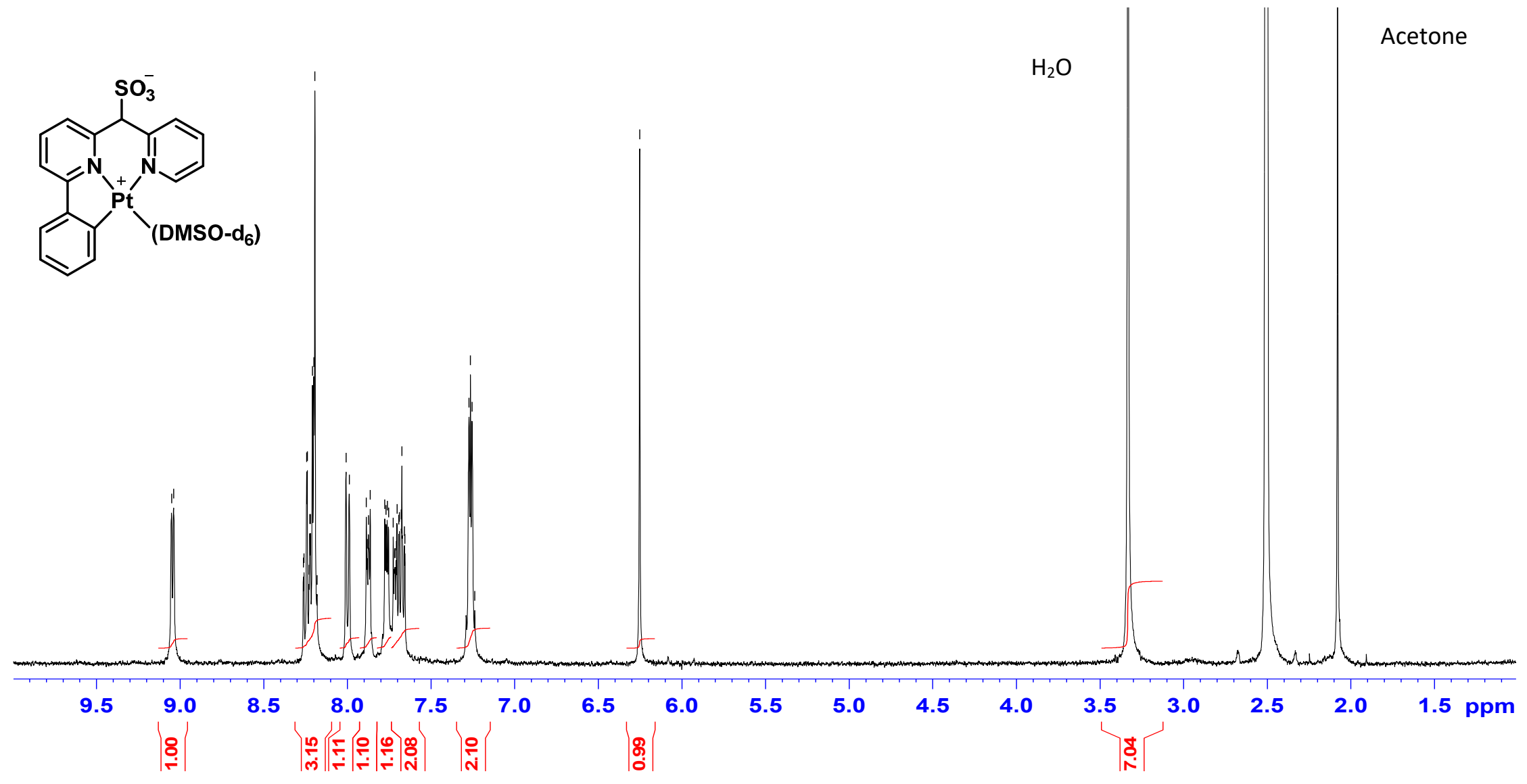

DMSO

Figure S21. ${ }^{1} \mathrm{H}$ NMR of $\left(\mathrm{C}_{6} \mathrm{H}_{4}-\mathrm{dpms}\right) \mathrm{Pt}\left(\mathrm{OH}_{2}\right), 7$, in DMSO-d6. 


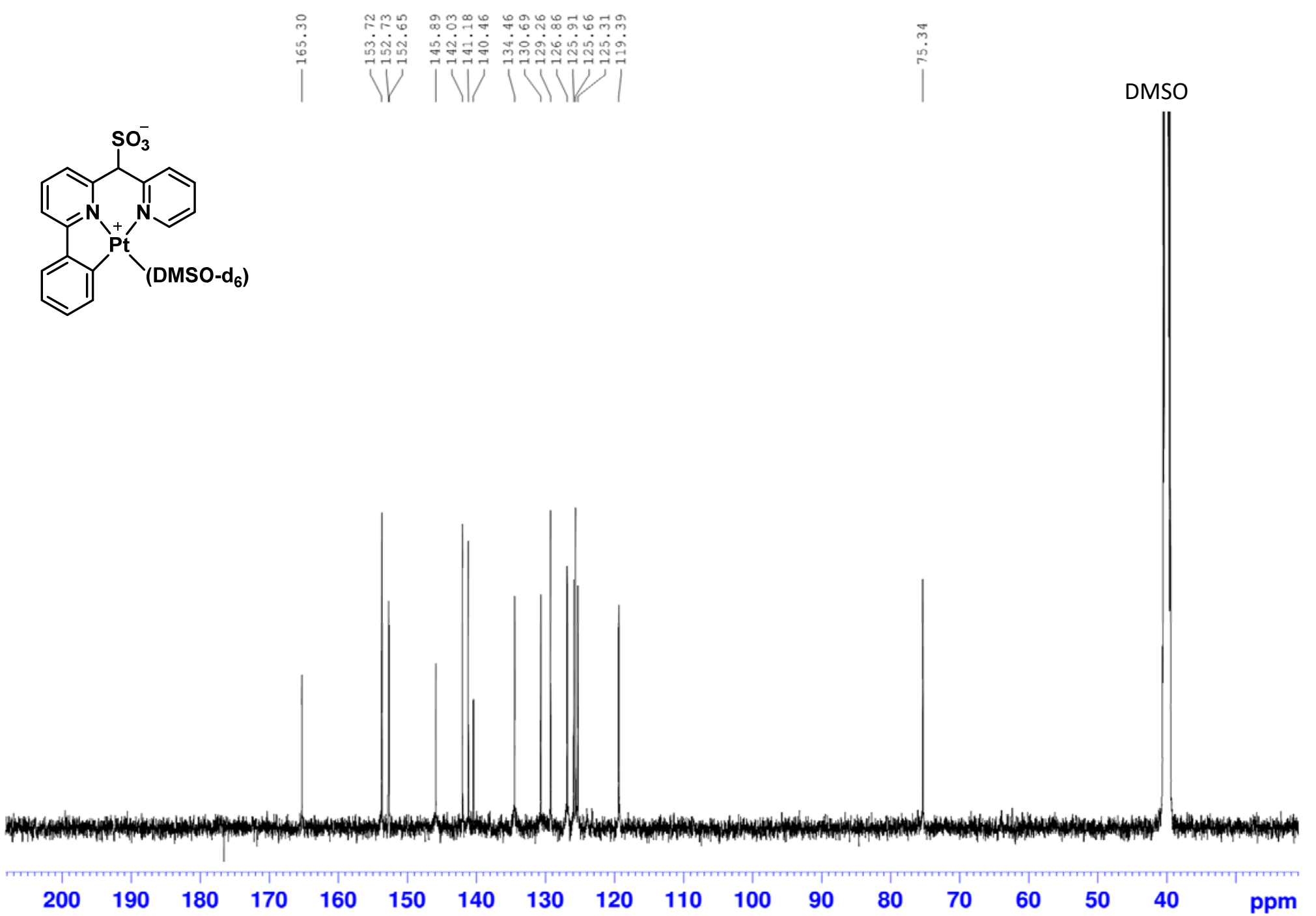

Figure S22. ${ }^{13} \mathrm{C}$ NMR of $\left(\mathrm{C}_{6} \mathrm{H}_{4}-\mathrm{dpms}\right) \mathrm{Pt}\left(\mathrm{OH}_{2}\right), 7$, in DMSO-d6. 


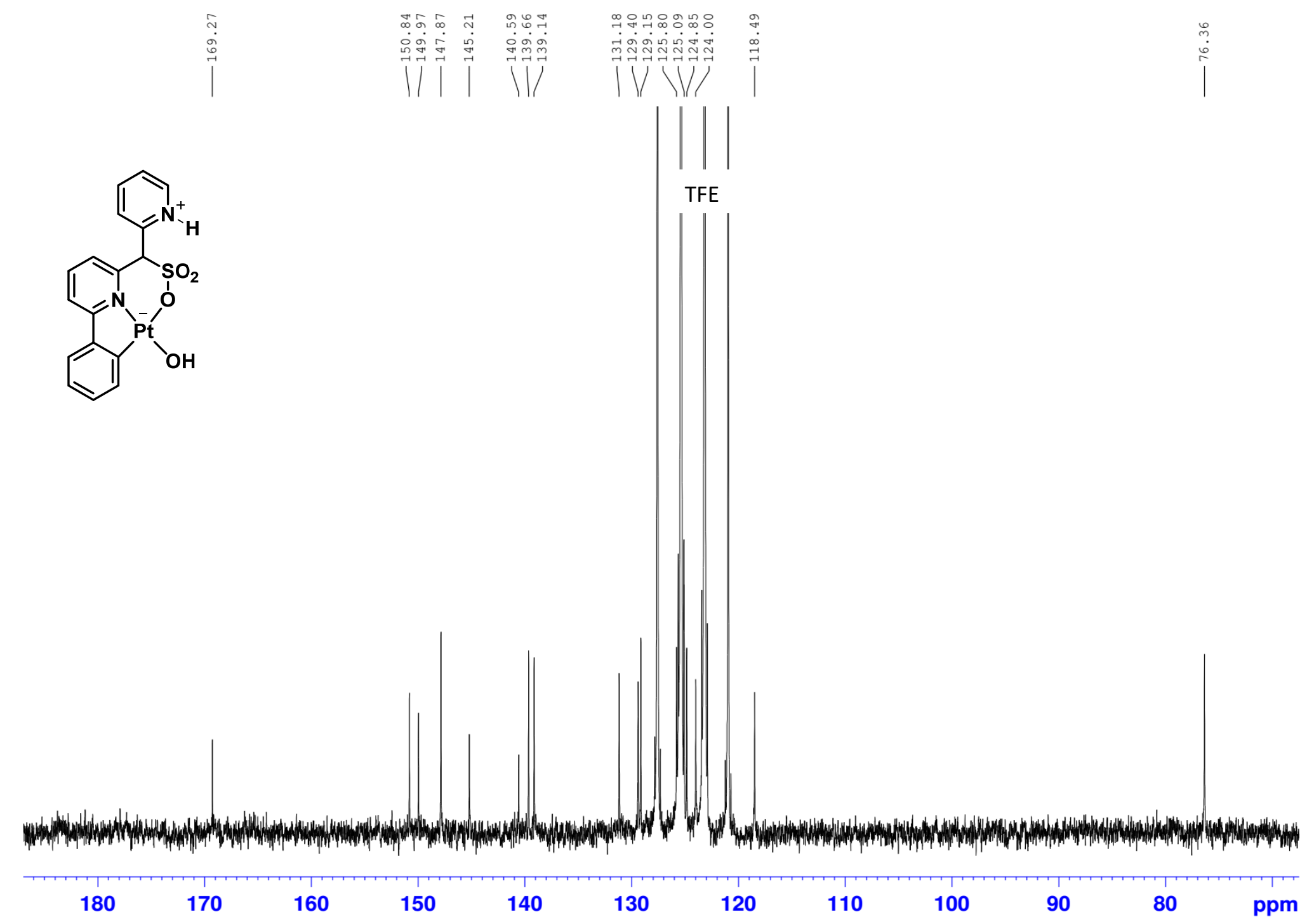

Figure S23. ${ }^{13} \mathrm{C}$ NMR of $\left(\mathrm{C}_{6} \mathrm{H}_{4}-\mathrm{dpms}-\mathrm{H}\right) \mathrm{Pt}(\mathrm{OH}), 13$, in TFE. 


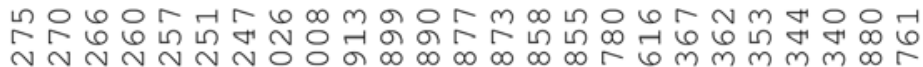

$\longrightarrow$

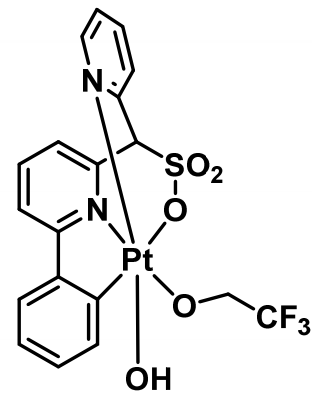

$\begin{array}{llll}8.5 & 8.0 & 7.5 & 7.0\end{array}$

|

$6.5 \quad 6.0$

5.5

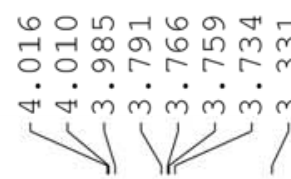

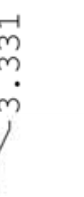

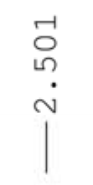

$\mathrm{Et}_{2} \mathrm{O}$

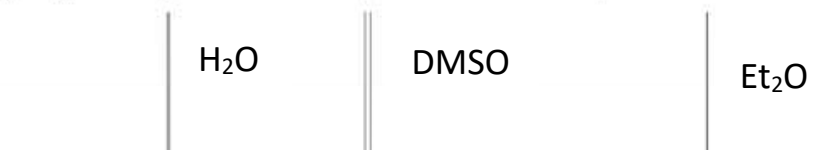

DCM
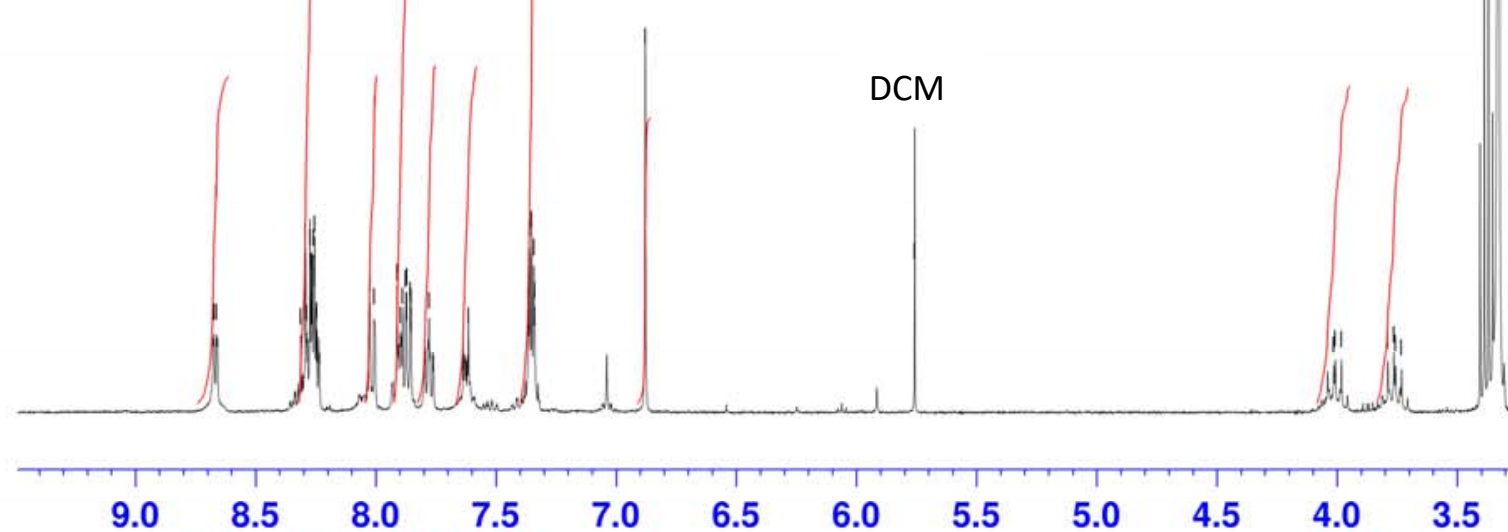

3.0

|

2.0

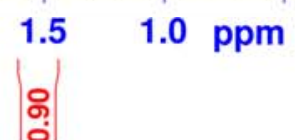

Figure S24. ${ }^{1} \mathrm{H}$ NMR of $\left(\mathrm{C}_{6} \mathrm{H}_{4}-\mathrm{dpms}\right) \mathrm{Pt}\left(\mathrm{OCH}_{2} \mathrm{CF}_{3}\right)(\mathrm{OH}), 15$, in DMSO-d6. 


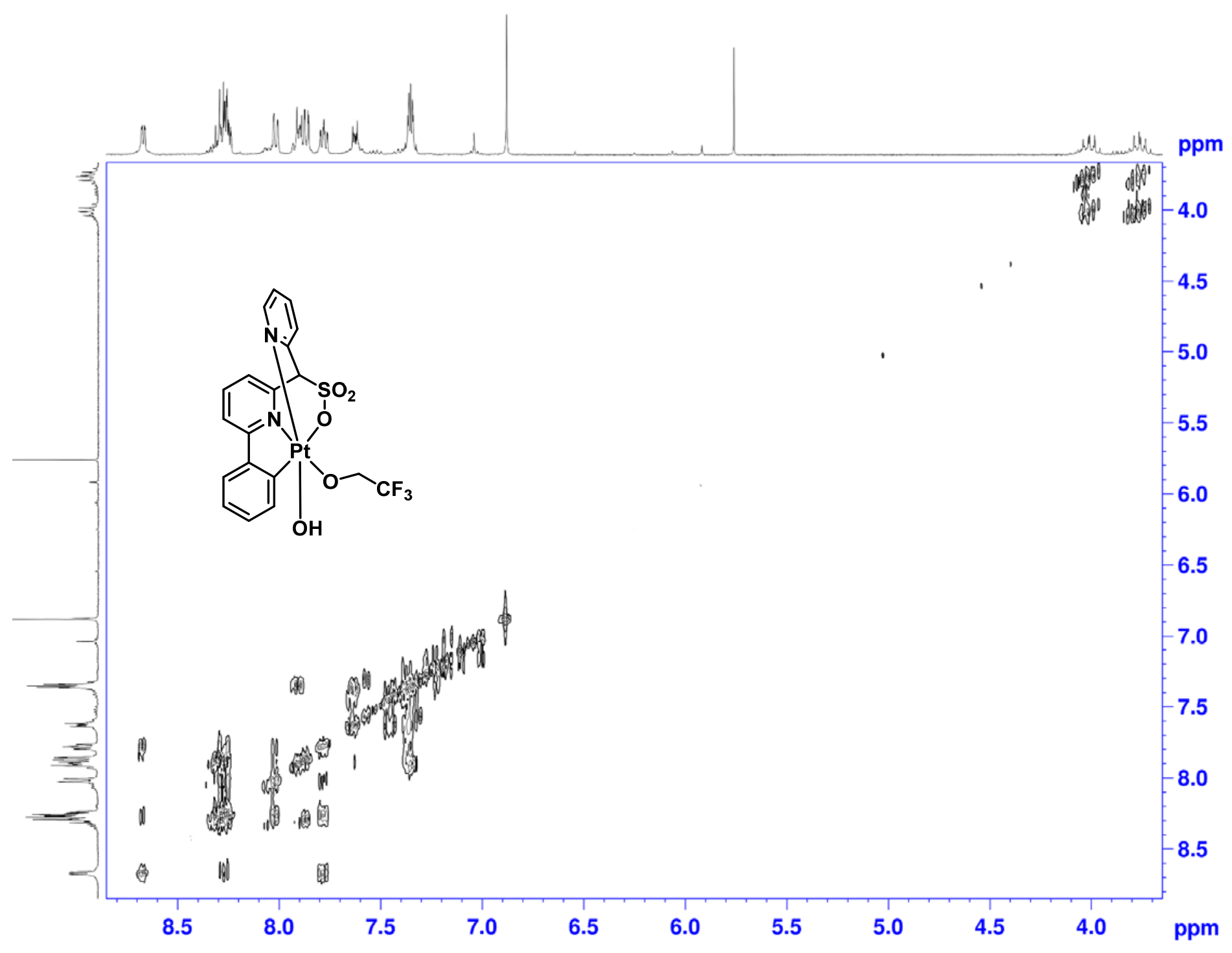

Figure S25. ${ }^{1} \mathrm{H}-{ }^{1} \mathrm{H}$ COSY NMR of $\left(\mathrm{C}_{6} \mathrm{H}_{4}-\mathrm{dpms}\right) \mathrm{Pt}\left(\mathrm{OCH}_{2} \mathrm{CF}_{3}\right)(\mathrm{OH}), 15$, in DMSO-d6 


\section{DFT Calculations}

Theoretical calculations in this work have been performed using density functional theory (DFT) method, ${ }^{2}$ specifically functional PBE, ${ }^{3}$ and LACVP relativistic basis set with two polarization functions implemented in the Jaguar program ${ }^{4}$ package. This combination of the functional and basis set has successfully been used in our previous works dealing with DFT-modeling of Ar-X bond reductive elimination from $\mathrm{Pt}(\mathrm{IV})$ center (see, e.g., Angew. Chem. Int. Edit. 2015, 54, 12447). In these works by using experimental data we were able to validate results of our theoretical calculations. Full geometry optimization has been performed without constraints on symmetry in 2,2,2-trifluoroethol as a solvent using a Poisson-Boltzmann continuum solvation model (PBF) ${ }^{3}$. For all species under investigation frequency analysis has been carried out. All energy minima have been checked for the absence of imaginary frequencies. All transition states possessed just one imaginary frequency. Using the method of Intrinsic Reaction Coordinate, reactants, products and the corresponding transition states were proven to be connected by a single minimal energy reaction path.

For gas-phase geometry-optimized species and for species with geometry optimization in TFE solution the total gas phase Gibbs free energy (Gtot) at $298 \mathrm{~K}$ is given in Hartrees $(1$ Hartree $=627.51 \mathrm{kcal} / \mathrm{mol}$ ).

The standard reaction Gibbs energies, $\Delta \mathrm{G}_{\mathrm{rxn}}$, in $\mathrm{kcal} / \mathrm{mol}$ (the standard state for all solutes is $1 \mathrm{M}$ concentration and $13.84 \mathrm{M}$ concentration for TFE solvent; for gaseous reaction the standard state is also $1 \mathrm{M}$ concentration for all components) were calculated as follows:

$\Delta \mathrm{G}_{\mathrm{rxn}}=627.51 *\left[\Sigma(\mathrm{Gtot})_{\text {products }}-\Sigma(\mathrm{Gtot})_{\text {reactants }}\right]_{\mathrm{TFE}}+\Delta n R T \ln (\mathrm{RT} / \mathrm{P})$

In a few cases when a TS could not be located during geometry optimization in TFE its Gibbs energy was calculated using gas phase geometry and single point solvation energies Gsolv:

$\Delta \mathrm{G}_{\mathrm{rxn}}=627.51 *\left[\Sigma(\mathrm{Gtot})_{\text {products }}-\Sigma(\mathrm{Gtot})_{\text {reactants }}\right]_{\text {gas phase }}+\Sigma(\mathrm{Gsolv})_{\text {products }}-\Sigma(\mathrm{Gsolv})$ reactants $+\Delta n R T \ln (\mathrm{RT} / \mathrm{P})$

where $\Delta n$ is the difference in the number of moles in a balanced reaction equation when going from reactants to products. 


\section{Composition of aged TFE solutions of 7}

To get more insight into possible composition of aged TFE solutions of 7 we used the DFT calculations.

The relative Gibbs energies of the gaseous components are given in Scheme S3. The calculations predict a $-1.9 \mathrm{kcal} / \mathrm{mol}$ Gibbs energy change when going from 7 to a hydrogen bond - stabilized adduct 13-TFE; the corresponding reaction leading to 13 lacking such stabilization is thermodynamically uphill, $+7.0 \mathrm{kcal} / \mathrm{mol}$. The TFE-for- $\mathrm{H}_{2} \mathrm{O}$ ligand exchange reactions leading to 10,12 and 14 are all thermodynamically uphill with about the equal reaction energies ranging from $+5.8(14)$ to $+6.1 \mathrm{kcal} / \mathrm{mol}(10$ and 12$)$. Note also that, except the direct transformation of 13-TFE and 14, all ligand exchange and isomerization reactions are low barrier processes with the Gibbs activation energies ranging from $\Delta G^{\#}=0.5$ to $13 \mathrm{kcal} / \mathrm{mol}$.

The equilibria involving TFE and complexes 7, 10 - 14 were analyzed also in TFE solutions at $[\mathrm{Pt}]=15 \mathrm{mM}$ with $\left[\mathrm{H}_{2} \mathrm{O}\right]=60 \mathrm{mM}$ originating from the samples of $7 \cdot 4 \mathrm{H}_{2} \mathrm{O}$, that were typically employed in our experiments (Scheme S4). These calculations predict the predominance of $\mathbf{1 4}$ which is mostly because of the low $\left[\mathrm{H}_{2} \mathrm{O}\right]=60 \mathrm{mM}$; for $\left[\mathrm{H}_{2} \mathrm{O}\right]=1 \mathrm{M}$ the corresponding reaction energy is $-0.2 \mathrm{kcal} / \mathrm{mol}$. Hydrogen - bonding stabilization of $\mathbf{1 4}$ is not efficient, according to our calculations, presumably, because of the low basicity of the trifluoroethoxide ligand in $\mathbf{1 4}$, as compared to the $\mathrm{OH}$ ligand in $\mathbf{1 3 .}$ Formation of the adduct $13-\mathrm{TFE}$ is slightly unfavorable $(+1.0 \mathrm{kcal} / \mathrm{mol})$, as compared to the Gibbs energy of 7 and neat TFE.

Based on our experimental observations, we believe that 14 is erroneously predicted to be the predominant $\mathrm{Pt}$-containing species in our working systems. This error is of the magnitude of a few $\mathrm{kcal} / \mathrm{mol}$ which is not uncommon for DFT calculations, and is, most likely, a result of an imperfection of the continuum solvation model used in modeling of the solvent effects.

Considering the possibility of a fluxional behavior for the complexes in Scheme S4, it is worth noting that, except direct transformations of 13 and 14 as well as 11 and 12, the corresponding activation barriers are low enough also in TFE so that a mixture of TFE complexes of similar stability may be fluxional at $21^{\circ} \mathrm{C}$ and above.

Hence, except an overestimation of the solvation energy for 14 and underestimation of the stability of $\mathbf{1 3}$ in TFE by a few $\mathrm{kcal} / \mathrm{mol}$, the DFT calculations agree with the assignment of 13-TFE as the major component of TFE solutions of 7 and with the assignment of a mixture of 10,12 and 14 as a minor fluxional component of such solutions at $21^{\circ} \mathrm{C}$.

This uncertainty is determining the most stable species in TFE solutions of 7 will "cost" an error of a few $\mathrm{kcal} / \mathrm{mol}$ in predicting the overall reaction energy profile (Tables 9 and 10 in the main text). 
Scheme S3. The relative Gibbs energies of some components of the system $7+$ TFE in gas phase at $298 \mathrm{~K}$.

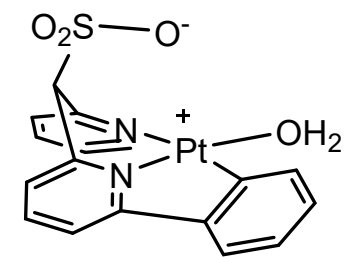

(0)

7

$\| \Delta \mathrm{G}_{7-11}^{\#} 6.8$<smiles>O=S(=O)(O)c1ccc2n1P(O)(O)(c1ccccn1)c1ccccc1-2</smiles>

0.3

11

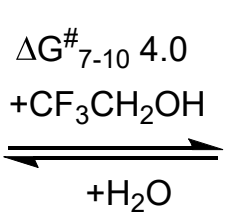

\begin{tabular}{c}
$\Delta \mathrm{G}^{\# 11-12} 12.6$ \\
slow \\
$+\mathrm{CF}_{3} \mathrm{CH}_{2} \mathrm{OH}$ \\
\hline$+\mathrm{H}_{2} \mathrm{O}$
\end{tabular}

$\Delta \mathrm{G}_{13-11}^{\#} 3.7 \|+\mathrm{CF}_{3} \mathrm{CH}_{2} \mathrm{OH}$

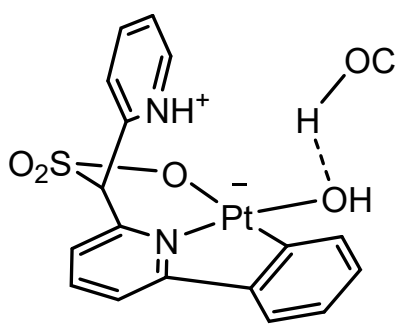

$-1.9$

13

$\Delta \mathrm{G}^{\#}{ }_{13-14} 23.4$

TFE-assisted

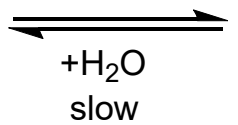

$\Delta G^{\#}{ }_{14-12} 0.5$
TFE-assisted

12

6.1

10

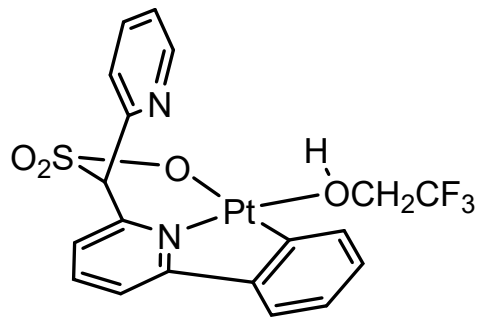

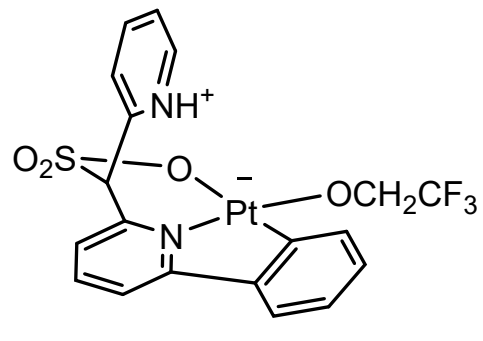

14

5.8

standard state, $1 \mathrm{M}$ 
Scheme S4. The relative Gibbs energies of some components of the system $7 \cdot 4 \mathrm{H}_{2} \mathrm{O} /$ TFE at $[\mathrm{Pt}]=15 \mathrm{mM}$ and $\left[\mathrm{H}_{2} \mathrm{O}\right]=60 \mathrm{mM}$ at $298 \mathrm{~K}$.

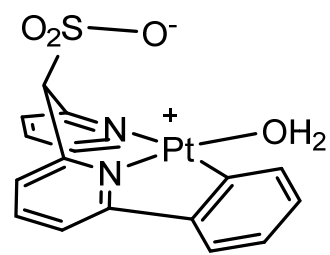

(0)

7

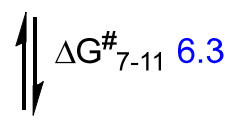<smiles>O=S(=O)(O)c1ccc2n1P(O)c1ccccc1-c1cccc(n1)O2</smiles>

1.0

11

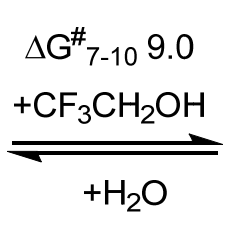

$\Delta G^{\#}{ }_{11-12} 18.4$

slow

$+\mathrm{CF}_{3} \mathrm{CH}_{2} \mathrm{OH}$

$+\mathrm{H}_{2} \mathrm{O}$

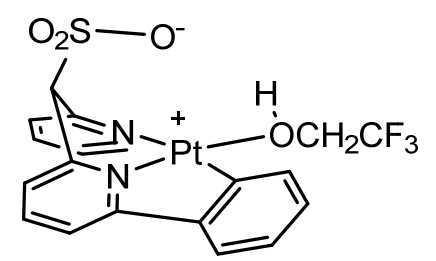

10

4.1
$\|_{\Delta G^{\#-12}} 6.6$

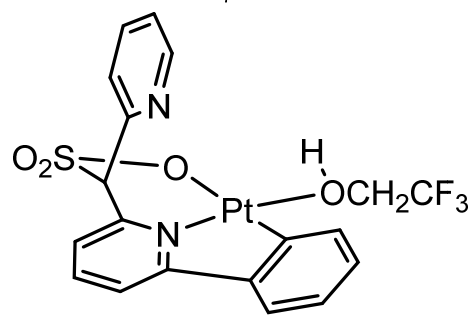

12
6.1

$\Delta \mathrm{G}^{\#}{ }_{14-12} 8.2$

$\Delta \mathrm{G}_{13-11}^{\#} 2.7 \|+\mathrm{CF}_{3} \mathrm{CH}_{2} \mathrm{OH}$ TFE-assisted

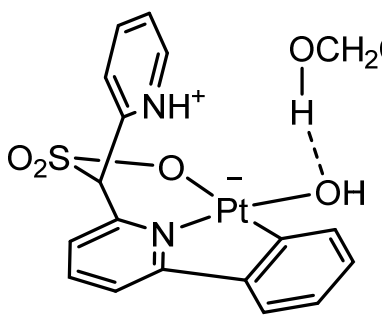

1.0

13-TFE

$\Delta \mathrm{G}^{\#}{ }_{13-14} 22.6$

TFE-assisted

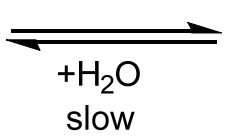

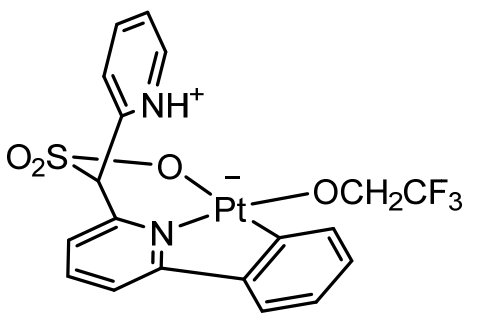

14 


\section{$\mathrm{H}_{2} \mathrm{O}$ (gas phase)}

The total Gibbs free energy, Gtot (Htot - T*S): $\quad-76.328348$ hartrees

$\begin{array}{lccc}\text { O1 } & 0.0000000000 & 0.0000000000 & -0.0678226289 \\ \text { H2 } & 0.0000000000 & 0.7609059546 & 0.5381971691 \\ \text { H3 } & 0.0000000000 & -0.7609059546 & 0.5381971691\end{array}$

\section{$\mathrm{H}_{2} \mathrm{O}$ (TFE)}

The total Gibbs free energy, Gtot (Htot $\left.-T^{*} \mathrm{~S}\right)$ : $\quad-76.340214$ hartrees

$\begin{array}{cccc}\text { O1 } & 0.0000000000 & 0.0000000000 & -0.0683568983 \\ \text { H2 } & 0.0000000000 & 0.7620241979 & 0.5424367911 \\ \text { H3 } & 0.0000000000 & -0.7620241979 & 0.5424367911\end{array}$

\section{$\mathrm{CF}_{3} \mathrm{CH}_{2} \mathrm{OH}$ (gas phase)}

The total Gibbs free energy, Gtot (Htot - T*S): $\quad-452.276800$ hartrees

$\begin{array}{lrrr}\text { C1 } & -0.5594504210 & 0.5630985049 & 2.4192073398 \\ \text { F2 } & -1.3288300635 & 1.3282901649 & 3.2553005108 \\ \text { F3 } & -1.3952155909 & -0.1779462393 & 1.6456853818 \\ \text { F4 } & 0.1603507466 & -0.2806944900 & 3.1926657604 \\ \text { C5 } & 0.3180836224 & 1.4664789487 & 1.5574144250 \\ \text { H6 } & 0.9837292914 & 0.8317564583 & 0.9519476482 \\ \text { H7 } & -0.3581332851 & 2.0121384835 & 0.8672464201 \\ \text { O8 } & 1.1324350542 & 2.3137547071 & 2.3386644956 \\ \text { H9 } & 0.5297479348 & 2.8353132654 & 2.9013374586\end{array}$

\section{$\mathrm{CF}_{3} \mathrm{CH}_{2} \mathrm{OH}$ (TFE)}

The total Gibbs free energy, Gtot (Htot $\left.-\mathrm{T}^{*} \mathrm{~S}\right)$ : $\quad-452.284220$ hartrees

$\begin{array}{lrrr}\text { C1 } & -0.5658586415 & 0.5732484664 & 2.4125326816 \\ \text { F2 } & -1.3509233512 & 1.2989719126 & 3.2620269965 \\ \text { F3 } & -1.3915436810 & -0.1728063744 & 1.6263013946 \\ \text { F4 } & 0.1656072346 & -0.2797522441 & 3.1761402080 \\ \text { C5 } & 0.3190646022 & 1.4870220548 & 1.5676182424 \\ \text { H6 } & 0.9732806131 & 0.8465351810 & 0.9511040602 \\ \text { H7 } & -0.3393493326 & 2.0641574510 & 0.8892193484 \\ \text { O8 } & 1.1487009962 & 2.3058035522 & 2.3747853570 \\ \text { H9 } & 0.5760515294 & 2.9672711264 & 2.8150494069\end{array}$




\section{Complex 7 (gas phase)}

The total Gibbs free energy, Gtot (Htot - T*S): $\quad-1582.361465$ hartrees

$\begin{array}{lccc} & & & \\ \text { C1 } & 0.3863752760 & 0.2199828925 & -3.2500788371 \\ \text { C2 } & -0.5474077180 & 0.9636168071 & -2.5190526345 \\ \text { H3 } & 0.3276403593 & 0.1882523855 & -4.3417455768 \\ \text { C4 } & 1.4317676575 & -0.4264991040 & -2.5846103221 \\ \text { C5 } & -0.4830683842 & 0.9821890542 & -1.1164891720 \\ \text { H6 } & -1.3188027361 & 1.5506063914 & -3.0223057166 \\ \text { C7 } & 4.8124811625 & -1.6574512561 & 0.1400344946 \\ \text { C8 } & 1.4935753025 & -0.3756687942 & -1.1850242447 \\ \text { H9 } & 2.2271858837 & -0.9281751976 & -3.1402862269 \\ \text { C10 } & 3.7607693236 & -1.4334087912 & -0.7536707174 \\ \text { N11 } & 0.4636633743 & 0.2236703926 & -0.4948143451 \\ \text { C12 } & 4.7078828405 & -1.2098561947 & 1.4674544896 \\ \text { C13 } & 2.6024179775 & -0.7635997448 & -0.3179543647 \\ \text { C14 } & 3.5511879642 & -0.5477795320 & 1.9097665369 \\ \text { C15 } & 2.4761781727 & -0.3147929461 & 1.0366518685 \\ \text { H16 } & 5.7151771355 & -2.1758269662 & -0.1958997774 \\ \text { H17 } & 3.8452383456 & -1.7807600420 & -1.7888996381 \\ \text { H18 } & 5.5354009374 & -1.3793761620 & 2.1644319538 \\ \text { H19 } & 3.4924148896 & -0.2228686048 & 2.9554127149 \\ \text { P120 } & 0.6583039919 & 0.3768682279 & 1.4597802624 \\ \text { O21 } & 0.8660531975 & 1.3648867512 & 3.3798598693 \\ \text { H22 } & 1.8135387370 & 1.5754571658 & 3.4849896013 \\ \text { H23 } & 0.4564338977 & 2.2041261111 & 2.9151315193 \\ \text { S24 } & -0.3523090295 & 3.4366939079 & 0.4667625241 \\ \text { O25 } & 0.9808855844 & 3.3636759128 & -0.1888857273 \\ \text { C26 } & -1.3715692070 & 1.8849966596 & -0.3116110000 \\ \text { C27 } & -2.1612976524 & 1.2818130492 & 0.7963565216 \\ \text { C28 } & -3.5543747667 & 1.4312639148 & 0.9002855983 \\ \text { C29 } & -4.2224679080 & 0.9021747558 & 2.0072885951 \\ \text { C30 } & -3.4848585192 & 0.2318245547 & 2.9933956935 \\ \text { C31 } & -2.1037200995 & 0.1173113104 & 2.8306382089 \\ \text { N32 } & -1.4625496620 & 0.6306836619 & 1.7597276081 \\ \text { O33 } & -0.3242056309 & 3.2082022276 & 1.9803584276 \\ \text { O34 } & -1.2611066724 & 4.5505662854 & 0.0930680283 \\ \text { H35 } & -2.0390815098 & 2.4193375345 & -1.0006674248 \\ \text { H36 } & -4.0944706931 & 1.9705413387 & 0.1183255018 \\ \text { H37 } & -5.3065802303 & 1.0129268497 & 2.1022100666 \\ \text { H38 } & -3.9653257086 & -0.1945003185 & 3.8770510935 \\ \text { H39 } & -1.4702448691 & -0.3867170590 & 3.5660104809\end{array}$




\section{Complex 7 (TFE)}

The total Gibbs free energy, Gtot (Htot - T*S): $\quad-1582.398537$ hartrees

\begin{tabular}{lccc} 
& & & \\
C1 & 0.2635359094 & 0.0313366473 & -3.1825484868 \\
C2 & -0.6342122732 & 0.8407295165 & -2.4750397274 \\
H3 & 0.1499835007 & -0.1065291732 & -4.2630530079 \\
C4 & 1.3298202329 & -0.5682242695 & -2.5068468262 \\
C5 & -0.4924020077 & 0.9992349095 & -1.0864450173 \\
H6 & -1.4480534853 & 1.3543921514 & -2.9952849396 \\
C7 & 4.6250294748 & -2.0320631525 & 0.2000829407 \\
C8 & 1.4591956028 & -0.3932951443 & -1.1197794657 \\
H9 & 2.0756079774 & -1.1492290051 & -3.0568040813 \\
C10 & 3.6122246166 & -1.6695987545 & -0.6965649188 \\
N11 & 0.5008507988 & 0.3290399245 & -0.4358107817 \\
C12 & 4.5813280288 & -1.5648079876 & 1.5256555366 \\
C13 & 2.5562490134 & -0.8404160270 & -0.2644940698 \\
C14 & 3.5300199116 & -0.7390130984 & 1.9625577328 \\
C15 & 2.4983484011 & -0.3573718890 & 1.0847951393 \\
H16 & 5.4417542559 & -2.6817532201 & -0.1284067810 \\
H17 & 3.6366795330 & -2.0456500534 & -1.7257438732 \\
H18 & 5.3686038233 & -1.8527688559 & 2.2315216299 \\
H19 & 3.5238116350 & -0.4140214086 & 3.0097896241 \\
P120 & 0.7621024451 & 0.5233976235 & 1.5233055085 \\
O21 & 1.1225819570 & 1.1081519942 & 3.5971808465 \\
H22 & 2.0789374605 & 1.2017210608 & 3.8003042843 \\
H23 & 0.7971630005 & 2.0383427665 & 3.6278144529 \\
S24 & -0.5634303840 & 3.5590561949 & 0.2513990457 \\
O25 & 0.6274462755 & 3.6909678833 & -0.6506756425 \\
C26 & -1.4176717046 & 1.9155252972 & -0.3259658101 \\
C27 & -2.1523062682 & 1.2564527180 & 0.8044162234 \\
C28 & -3.5535839309 & 1.1423784726 & 0.8072100179 \\
C29 & -4.1845606637 & 0.4224478330 & 1.8286196989 \\
C30 & -3.3978506148 & -0.1439257247 & 2.8422568316 \\
C31 & -2.0138320920 & 0.0395255102 & 2.7984561293 \\
N32 & -1.4021239601 & 0.7232954880 & 1.8027985346 \\
O33 & -0.2298278206 & 3.4082442491 & 1.7156580805 \\
O34 & -1.6516408532 & 4.5659193883 & 0.0039105634 \\
H35 & -2.1490306537 & 2.3063762883 & -1.0477918712 \\
H36 & -4.1361262417 & 1.5957516409 & -0.0009897111 \\
H37 & -5.2727448717 & 0.2946368046 & 1.8273752063 \\
H38 & -3.8420976212 & -0.7304978594 & 3.6508029354 \\
H39 & -1.3556175441 & -0.3830751374 & 3.5634082244 \\
& & & \\
\hline
\end{tabular}




\section{Complex 10 (gas phase)}

The total Gibbs free energy, Gtot (Htot - T*S): $\quad-1958.300257$ hartrees

$\begin{array}{lccc}\text { Pt1 } & -0.0444873338 & -0.9416018220 & -0.4973801911 \\ \text { O2 } & -0.4191492323 & -2.9897074572 & 0.1357494667 \\ \text { H3 } & -0.3804846169 & -2.6150164174 & 1.1343638951 \\ \text { C4 } & 0.5701577849 & -4.0139408459 & 0.0112554034 \\ \text { N5 } & -1.9488000272 & -0.6345904102 & 0.4746389528 \\ \text { C6 } & -3.0678518188 & -1.2675729378 & 0.0644894491 \\ \text { H7 } & -2.9337052369 & -1.9959006299 & -0.7398413445 \\ \text { C8 } & -4.3132431898 & -1.0178499465 & 0.6422671398 \\ \text { H9 } & -5.1952118728 & -1.5545546199 & 0.2852749590 \\ \text { C10 } & -4.3952017156 & -0.0787417206 & 1.6798904735 \\ \text { H11 } & -5.3545628858 & 0.1405667938 & 2.1574264223 \\ \text { C12 } & -3.2329852213 & 0.5717638005 & 2.1022980738 \\ \text { H13 } & -3.2560325397 & 1.2980821808 & 2.9183585288 \\ \text { C14 } & -2.0101651423 & 0.2732639512 & 1.4798521071 \\ \text { C15 } & -0.7166685215 & 0.8602234191 & 1.9266345715 \\ \text { H16 } & -0.8846680394 & 1.5380703355 & 2.7741348986 \\ \text { S17 } & 0.3191802759 & -0.5985654870 & 2.8314753595 \\ \text { O18 } & -0.3756233524 & -1.9083624984 & 2.4298112896 \\ \text { O19 } & 1.7042626559 & -0.4627086852 & 2.3073308762 \\ \text { O20 } & 0.0659405789 & -0.2627066558 & 4.2540808015 \\ \text { N21 } & 0.4843892840 & 0.9437072411 & -0.2467649597 \\ \text { C22 } & 0.1136842351 & 1.5775592254 & 0.9024075036 \\ \text { C23 } & 0.5867592150 & 2.8771083128 & 1.1411439127 \\ \text { H24 } & 0.2751656033 & 3.3954112480 & 2.0505673648 \\ \text { C25 } & 1.4648455395 & 3.4779613944 & 0.2315391120 \\ \text { H26 } & 1.8226729252 & 4.4964871585 & 0.4063914496 \\ \text { C27 } & 1.9302656206 & 2.7487225427 & -0.8650865489 \\ \text { H28 } & 2.6878848554 & 3.1619738329 & -1.5344984846 \\ \text { C29 } & 1.4640870876 & 1.4425485520 & -1.0738637432 \\ \text { C30 } & 1.9781053115 & 0.4438704202 & -2.0040375845 \\ \text { C31 } & 2.9330308259 & 0.7109315413 & -3.0039406365 \\ \text { H32 } & 3.2839528963 & 1.7340958129 & -3.1761108826 \\ \text { C33 } & 3.4344426738 & -0.3352640519 & -3.7841844604 \\ \text { H34 } & 4.1768306137 & -0.1340276808 & -4.5616672819 \\ \text { C35 } & 2.9811739773 & -1.6458371704 & -3.5595713829 \\ \text { H36 } & 3.3771935877 & -2.4684330034 & -4.1644149601 \\ \text { C37 } & 2.0250470381 & -1.9151729430 & -2.5663703116 \\ \text { H38 } & 1.6894819757 & -2.9475594062 & -2.4248208522 \\ \text { C39 } & 1.4956383939 & -0.8860664697 & -1.7711122016 \\ \text { H40 } & 0.0765902123 & -5.2841267795 & 0.6997396471 \\ & 0.7148030012 & -4.2385514640 & -1.0552310365 \\ \text { H4 } & 1.5323192840 & -3.7087812469 & 0.4574985119 \\ \text { H3 } & 1.0201180499 & -6.2558106303 & 0.5781814178\end{array}$


F44

F45
$-0.1561685797$

$-1.0714992959$
$-5.0775334266$

$-5.7413400590$
2.0168133051

0.1389978368 


\section{Complex 10 (TFE)}

The total Gibbs free energy, Gtot (Htot - T*S): $\quad-1958.33095$ hartrees

$\begin{array}{lccc}\text { Pt1 } & -0.0284132733 & -0.9594468049 & -0.4874164764 \\ \text { O2 } & -0.3897373326 & -3.0485192408 & 0.0634089844 \\ \text { H3 } & -0.3419124159 & -2.7412112592 & 1.0380726705 \\ \text { C4 } & 0.5690637332 & -4.1087757277 & -0.1233725124 \\ \text { N5 } & -1.9443618213 & -0.6436572185 & 0.4836147423 \\ \text { C6 } & -3.0706760146 & -1.2556585827 & 0.0511601831 \\ \text { H7 } & -2.9441320614 & -1.9756462502 & -0.7630389614 \\ \text { C8 } & -4.3238231740 & -0.9846814750 & 0.6067073491 \\ \text { H9 } & -5.2096482554 & -1.5041971931 & 0.2289145293 \\ \text { C10 } & -4.4094230824 & -0.0452700750 & 1.6453476510 \\ \text { H11 } & -5.3758975550 & 0.1878598799 & 2.1066907137 \\ \text { C12 } & -3.2417393125 & 0.5938399260 & 2.0807749807 \\ \text { H13 } & -3.2694504945 & 1.3347725031 & 2.8842640843 \\ \text { C14 } & -2.0153066519 & 0.2738797628 & 1.4797206301 \\ \text { C15 } & -0.7242518370 & 0.8754326033 & 1.9399851866 \\ \text { H16 } & -0.9234603598 & 1.5914160891 & 2.7504822280 \\ \text { S17 } & 0.2908554434 & -0.4984645906 & 2.8966947309 \\ \text { O18 } & -0.2612322056 & -1.8546029230 & 2.4666490158 \\ \text { O19 } & 1.7212914521 & -0.2647897991 & 2.5269761083 \\ \text { O20 } & -0.0684782220 & -0.1983041633 & 4.3197891715 \\ \text { N21 } & 0.4920502930 & 0.9303742299 & -0.2324433872 \\ \text { C22 } & 0.1080853521 & 1.5816705141 & 0.9024755246 \\ \text { C23 } & 0.5621135021 & 2.8894528061 & 1.1228697148 \\ \text { H24 } & 0.2380664429 & 3.4143695436 & 2.0253227778 \\ \text { C25 } & 1.4282741841 & 3.4929911990 & 0.1994850192 \\ \text { H26 } & 1.7672118460 & 4.5227992757 & 0.3558111590 \\ \text { C27 } & 1.9011721623 & 2.7547855279 & -0.8909635642 \\ \text { H28 } & 2.6426029159 & 3.1800544760 & -1.5743148002 \\ \text { C29 } & 1.4576750495 & 1.4350387209 & -1.0762157500 \\ \text { C30 } & 1.9747112509 & 0.4317825143 & -2.0068452658 \\ \text { C31 } & 2.9174486470 & 0.6990204991 & -3.0200113122 \\ \text { H32 } & 3.2605280937 & 1.7239681384 & -3.1990167614 \\ \text { C33 } & 3.4088923259 & -0.3489244354 & -3.8082478042 \\ \text { H34 } & 4.1386861266 & -0.1432627454 & -4.5973924488 \\ \text { C35 } & 2.9573035682 & -1.6612152566 & -3.5854989098 \\ \text { H36 } & 3.3434451341 & -2.4818120843 & -4.2014915132 \\ \text { C37 } & 2.0129275463 & -1.9306924911 & -2.5788702078 \\ \text { H38 } & 1.6694116047 & -2.9605830059 & -2.4435590758 \\ \text { C39 } & 1.5002418171 & -0.9010682975 & -1.7715948987 \\ \text { H40 } & 0.0837606723 & -5.3413325853 & 0.6327839271 \\ \text { H41 } & 0.6123735812 & -4.3504490708 & -1.1960836414 \\ & 1.5728042125 & -3.8280520043 & 0.2419346979 \\ \text { F43 } & 1.0170847094 & -6.3235054903 & 0.5623268621\end{array}$


$\begin{array}{llll}\text { F44 } & -0.1361028251 & -5.0520907034 & 1.9429608416\end{array}$

$\begin{array}{llll}\text { F45 } & -1.0773242716 & -5.8212293431 & 0.1219183799\end{array}$ 


\section{Complex 11 (gas phase)}

The total Gibbs free energy, Gtot (Htot - T*S): $\quad-1582.360953$ hartrees

\begin{tabular}{|c|c|c|c|}
\hline $\mathrm{C} 1$ & 0.9695878610 & 0.8260395937 & -3.3659364594 \\
\hline $\mathrm{C} 2$ & -0.1660453869 & 1.3237670479 & -2.7205687654 \\
\hline $\mathrm{H} 3$ & 1.0927941533 & 0.9515396024 & -4.4455145251 \\
\hline $\mathrm{C} 4$ & 1.9366566065 & 0.1605683061 & -2.6155779426 \\
\hline $\mathrm{C} 5$ & -0.3280626266 & 1.1512667822 & -1.3380751983 \\
\hline H6 & -0.9536473548 & 1.8320449010 & -3.2813273630 \\
\hline $\mathrm{C} 7$ & 4.7197244019 & -1.8333273938 & 0.2835800770 \\
\hline $\mathrm{C} 8$ & 1.7708518404 & 0.0198386548 & -1.2298409230 \\
\hline H9 & 2.8323824449 & -0.2473285478 & -3.0888512904 \\
\hline $\mathrm{C} 10$ & 3.9075371998 & -1.2460195591 & -0.6902830179 \\
\hline N11 & 0.6435959880 & 0.5287618620 & -0.6137149326 \\
\hline $\mathrm{C} 12$ & 4.3270526833 & -1.8026325097 & 1.6331988071 \\
\hline C13 & 2.6972763074 & -0.6323936033 & -0.3134892635 \\
\hline C14 & 3.1228999321 & -1.1926961134 & 2.0166494933 \\
\hline $\mathrm{C} 15$ & 2.2886879772 & -0.6047424455 & 1.0509545722 \\
\hline H16 & 5.6605347563 & -2.3108806471 & -0.0049347282 \\
\hline H17 & 4.2201890071 & -1.2671337526 & -1.7396149479 \\
\hline H18 & 4.9702822252 & -2.2555999425 & 2.3949962843 \\
\hline H19 & 2.8419915824 & -1.1629060828 & 3.0745174263 \\
\hline $\operatorname{Pt} 20$ & 0.5904596388 & 0.3352051933 & 1.3727268405 \\
\hline $\mathrm{O} 21$ & 0.4659921506 & 0.2623507866 & 3.5295949221 \\
\hline $\mathrm{H} 22$ & -0.2317381788 & 0.9707382080 & 3.5576665387 \\
\hline $\mathrm{H} 23$ & -0.0210816085 & -0.5663003173 & 3.7165031454 \\
\hline S24 & -1.5074333299 & 2.5598978950 & 0.8858211452 \\
\hline $\mathrm{O} 25$ & -0.3662140480 & 3.4902305152 & 0.7155276761 \\
\hline $\mathrm{C} 26$ & -1.6355330805 & 1.5814827690 & -0.7177169281 \\
\hline $\mathrm{C} 27$ & -2.6184028793 & 0.4283616007 & -0.5693372988 \\
\hline $\mathrm{C} 28$ & -3.9970718958 & 0.6896850551 & -0.4540909515 \\
\hline C29 & -4.8699285024 & -0.3939650688 & -0.3221298916 \\
\hline $\mathrm{C} 30$ & -4.3442199173 & -1.6931702857 & -0.3128360709 \\
\hline C31 & -2.9577030331 & -1.8452603232 & -0.4370387746 \\
\hline N32 & -2.1026510001 & -0.8155150289 & -0.5675031637 \\
\hline O33 & -1.2262054291 & 1.4195193802 & 1.9285227244 \\
\hline O34 & -2.8600131477 & 3.1253537236 & 1.1020498278 \\
\hline H35 & -2.0793441440 & 2.3434540021 & -1.3799244268 \\
\hline H36 & -4.3584347748 & 1.7208778499 & -0.4397481922 \\
\hline H37 & -5.9474317867 & -0.2257041561 & -0.2299794767 \\
\hline H38 & -4.9918269210 & -2.5693712998 & -0.2166134076 \\
\hline H39 & -2.5040853417 & -2.8443667132 & -0.4388136019 \\
\hline
\end{tabular}




\section{Complex 11 (TFE)}

The total Gibbs free energy, Gtot (Htot - T*S): $\quad-1582.396959$ hartrees

\begin{tabular}{|c|c|c|c|}
\hline $\mathrm{C} 1$ & 0.9695894384 & 0.7803347835 & -3.3863908876 \\
\hline $\mathrm{C} 2$ & -0.1626417799 & 1.2986147359 & -2.7448492124 \\
\hline H3 & 1.0831034637 & 0.8709530468 & -4.4722182582 \\
\hline $\mathrm{C} 4$ & 1.9382989679 & 0.1325537683 & -2.6201778015 \\
\hline $\mathrm{C} 5$ & -0.3158354355 & 1.1687712858 & -1.3553885381 \\
\hline H6 & -0.9561291933 & 1.7891783847 & -3.3164622103 \\
\hline $\mathrm{C} 7$ & 4.7305011396 & -1.8120525310 & 0.2912560724 \\
\hline $\mathrm{C} 8$ & 1.7768417707 & 0.0353662870 & -1.2273900992 \\
\hline H9 & 2.8216466146 & -0.3056521500 & -3.0921926112 \\
\hline $\mathrm{C} 10$ & 3.9152851789 & -1.2236513404 & -0.6823787094 \\
\hline N11 & 0.6604688084 & 0.5724529460 & -0.6098424066 \\
\hline $\mathrm{C} 12$ & 4.3277394220 & -1.7995754979 & 1.6390031933 \\
\hline $\mathrm{C} 13$ & 2.6949928908 & -0.6236102236 & -0.3062612420 \\
\hline $\mathrm{C} 14$ & 3.1071094871 & -1.2145959572 & 2.0193966289 \\
\hline $\mathrm{C} 15$ & 2.2687873992 & -0.6242837422 & 1.0560600219 \\
\hline H16 & 5.6803374690 & -2.2753808192 & 0.0053793867 \\
\hline H17 & 4.2379871633 & -1.2362523739 & -1.7295943542 \\
\hline H18 & 4.9723002268 & -2.2484383508 & 2.4038408864 \\
\hline H19 & 2.8178477328 & -1.2087303374 & 3.0753667341 \\
\hline Pt20 & 0.5708745498 & 0.3287525153 & 1.3905467265 \\
\hline $\mathrm{O} 21$ & 0.4085557663 & -0.0628412314 & 3.5232920570 \\
\hline $\mathrm{H} 22$ & -0.0142894990 & 0.7244936174 & 3.9409514959 \\
\hline $\mathrm{H} 23$ & -0.2588398419 & -0.7827798261 & 3.6215990179 \\
\hline $\mathrm{S} 24$ & -1.4867817366 & 2.6269028573 & 0.8119814044 \\
\hline $\mathrm{O} 25$ & -0.3668685222 & 3.5899914653 & 0.5863853064 \\
\hline $\mathrm{C} 26$ & -1.6335229297 & 1.6096562947 & -0.7497500394 \\
\hline $\mathrm{C} 27$ & -2.6053298147 & 0.4449641115 & -0.5541514903 \\
\hline $\mathrm{C} 28$ & -3.9914217244 & 0.6800808114 & -0.4623909689 \\
\hline $\mathrm{C} 29$ & -4.8450713033 & -0.4189145779 & -0.3017669802 \\
\hline $\mathrm{C} 30$ & -4.2920884366 & -1.7067220937 & -0.2477470707 \\
\hline C31 & -2.9002562051 & -1.8345828165 & -0.3541442024 \\
\hline N32 & -2.0651839756 & -0.7888867119 & -0.5046896660 \\
\hline O33 & -1.1844673733 & 1.5714878541 & 1.9089937315 \\
\hline O34 & -2.8336811370 & 3.2289486014 & 1.0363236038 \\
\hline H35 & -2.0864256249 & 2.3436310412 & -1.4411689470 \\
\hline H36 & -4.3858987230 & 1.6997889237 & -0.5074228674 \\
\hline H37 & -5.9281161230 & -0.2718905572 & -0.2298383838 \\
\hline H38 & -4.9227496684 & -2.5949636627 & -0.1396880479 \\
\hline H39 & -2.4297247912 & -2.8261724835 & -0.3308560979 \\
\hline
\end{tabular}


Complex 12 (gas phase)

The total Gibbs free energy, Gtot (Htot - T*S): $\quad-1958.300167$ hartrees

\begin{tabular}{|c|c|c|c|}
\hline $\mathrm{C} 1$ & 1.1260466372 & 1.0571136579 & -3.9421118418 \\
\hline $\mathrm{C} 2$ & -0.0191993772 & 1.5326203110 & -3.2966471306 \\
\hline $\mathrm{H} 3$ & 1.2613844464 & 1.2135392750 & -5.0161245057 \\
\hline $\mathrm{C} 4$ & 2.0857761405 & 0.3715672032 & -3.2004475355 \\
\hline $\mathrm{C} 5$ & -0.1940963662 & 1.3250911335 & -1.9210550845 \\
\hline H6 & -0.8036128605 & 2.0510580068 & -3.8524026945 \\
\hline $\mathrm{C} 7$ & 4.8079179542 & -1.7527319434 & -0.3340886798 \\
\hline $\mathrm{C} 8$ & 1.9057553809 & 0.1935524751 & -1.8207424235 \\
\hline H9 & 2.9865154299 & -0.0234864945 & -3.6751399589 \\
\hline $\mathrm{C} 10$ & 4.0156059348 & -1.1223617352 & -1.2973917013 \\
\hline N11 & 0.7754051118 & 0.6918409628 & -1.2031064939 \\
\hline $\mathrm{C} 12$ & 4.4069467363 & -1.7471394591 & 1.0129774420 \\
\hline $\mathrm{C} 13$ & 2.8163712131 & -0.4923855202 & -0.9132435166 \\
\hline C14 & 3.2139839351 & -1.1191924178 & 1.4034737788 \\
\hline $\mathrm{C} 15$ & 2.3975775888 & -0.4902043623 & 0.4485913903 \\
\hline H16 & 5.7392736460 & -2.2446940358 & -0.6288724334 \\
\hline H17 & 4.3340977904 & -1.1251174137 & -2.3450871932 \\
\hline H18 & 5.0340319394 & -2.2334337067 & 1.7676859228 \\
\hline H19 & 2.9309784442 & -1.1071279635 & 2.4617574237 \\
\hline Pt20 & 0.7094973092 & 0.4685574916 & 0.7787205328 \\
\hline $\mathrm{O} 21$ & 0.5636895534 & 0.3896504626 & 2.9316596604 \\
\hline $\mathrm{C} 22$ & -0.1941551937 & -0.7482886069 & 3.4077635511 \\
\hline $\mathrm{S} 23$ & -1.3898225458 & 2.7016145584 & 0.3067346108 \\
\hline $\mathrm{O} 24$ & -0.2560945364 & 3.6407609212 & 0.1382102647 \\
\hline $\mathrm{C} 25$ & -1.5093952431 & 1.7259426136 & -1.2988822950 \\
\hline $\mathrm{C} 26$ & -2.4725432338 & 0.5537695120 & -1.1572855421 \\
\hline $\mathrm{C} 27$ & -3.8521240437 & 0.7906746413 & -1.0050992976 \\
\hline $\mathrm{C} 28$ & -4.7065873909 & -0.3093242114 & -0.8885728193 \\
\hline $\mathrm{C} 29$ & -4.1633832928 & -1.6007678566 & -0.9313321365 \\
\hline $\mathrm{C} 30$ & -2.7777365126 & -1.7286202159 & -1.0879125727 \\
\hline N31 & -1.9396803690 & -0.6823809460 & -1.2029821689 \\
\hline $\mathrm{O} 32$ & -1.0954505835 & 1.5624837082 & 1.3477417362 \\
\hline $\mathrm{O} 33$ & -2.7466921514 & 3.2538375760 & 0.5274033319 \\
\hline H34 & -1.9679004138 & 2.4830802105 & -1.9565639650 \\
\hline H35 & -4.2273902342 & 1.8155138149 & -0.9511777213 \\
\hline H36 & -5.7840906201 & -0.1597278594 & -0.7686328440 \\
\hline H37 & -4.7968780236 & -2.4888280229 & -0.8503416670 \\
\hline H38 & -2.3100399109 & -2.7205065421 & -1.1301746728 \\
\hline C39 & -0.4509997082 & -0.5858938557 & 4.9021163549 \\
\hline $\mathrm{H} 40$ & -1.1554983367 & -0.8329622571 & 2.8753115901 \\
\hline H41 & 0.4166221726 & -1.6426220007 & 3.2250956700 \\
\hline F42 & -1.2118156844 & -1.6162298765 & 5.3454804131 \\
\hline F43 & 0.6974710841 & -0.5621939212 & 5.6148441245 \\
\hline
\end{tabular}


$\begin{array}{llll}\text { F44 } & -1.1166037223 & 0.5760101046 & 5.1413879242 \\ \text { H45 } & -0.0527711248 & 1.1709862137 & 2.9646565334\end{array}$ 


\section{Complex 12 (TFE)}

The total Gibbs free energy, Gtot (Htot - T*S): $\quad-1958.327675$ hartrees

\begin{tabular}{|c|c|c|c|}
\hline $\mathrm{C} 1$ & 1.1217483445 & 1.0350060875 & -3.9491881208 \\
\hline $\mathrm{C} 2$ & -0.0277198694 & 1.5145148206 & -3.3079088106 \\
\hline H3 & 1.2602373137 & 1.1805970711 & -5.0259183682 \\
\hline $\mathrm{C} 4$ & 2.0806841362 & 0.3563602244 & -3.1965730583 \\
\hline $\mathrm{C} 5$ & -0.2014050803 & 1.3214571911 & -1.9284287421 \\
\hline H6 & -0.8138810317 & 2.0269459076 & -3.8716161257 \\
\hline $\mathrm{C} 7$ & 4.7973549943 & -1.7653253158 & -0.3207090056 \\
\hline $\mathrm{C} 8$ & 1.8981848586 & 0.1933691271 & -1.8143240116 \\
\hline H9 & 2.9797304813 & -0.0496046102 & -3.6680116165 \\
\hline $\mathrm{C} 10$ & 4.0065002373 & -1.1293334660 & -1.2863745183 \\
\hline N11 & 0.7710064104 & 0.7023688413 & -1.1975054226 \\
\hline $\mathrm{C} 12$ & 4.3939527443 & -1.7644291035 & 1.0274082080 \\
\hline $\mathrm{C} 13$ & 2.8075067038 & -0.4946134263 & -0.9019594433 \\
\hline $\mathrm{C} 14$ & 3.1980251253 & -1.1356558766 & 1.4174041851 \\
\hline $\mathrm{C} 15$ & 2.3883373939 & -0.4971876919 & 0.4610535350 \\
\hline $\mathrm{H} 16$ & 5.7300711686 & -2.2580706373 & -0.6162626888 \\
\hline H17 & 4.3271401050 & -1.1334992009 & -2.3349837544 \\
\hline H18 & 5.0187169169 & -2.2559354276 & 1.7829515696 \\
\hline H19 & 2.9110938069 & -1.1369186975 & 2.4742384229 \\
\hline $\operatorname{Pt} 20$ & 0.7143565429 & 0.4876367780 & 0.7949611986 \\
\hline $\mathrm{O} 21$ & 0.6275586578 & 0.3083410944 & 2.9450798855 \\
\hline $\mathrm{C} 22$ & -0.1799582128 & -0.8112327166 & 3.4068107112 \\
\hline $\mathrm{S} 23$ & -1.4001629758 & 2.7238366535 & 0.2581923695 \\
\hline $\mathrm{O} 24$ & -0.2957573401 & 3.7050256206 & 0.0426273057 \\
\hline $\mathrm{C} 25$ & -1.5289166744 & 1.7264449443 & -1.3202015441 \\
\hline $\mathrm{C} 26$ & -2.4921136566 & 0.5473895722 & -1.1623368950 \\
\hline $\mathrm{C} 27$ & -3.8772373231 & 0.7713576556 & -1.0271623194 \\
\hline $\mathrm{C} 28$ & -4.7216840521 & -0.3387149738 & -0.8994290081 \\
\hline $\mathrm{C} 29$ & -4.1641493555 & -1.6254189558 & -0.9256831985 \\
\hline $\mathrm{C} 30$ & -2.7763166719 & -1.7406614313 & -1.0815375931 \\
\hline N31 & -1.9468280631 & -0.6848585381 & -1.1943881407 \\
\hline O32 & -1.0692545215 & 1.6590291034 & 1.3413546168 \\
\hline O33 & -2.7539374389 & 3.2967365235 & 0.4963800696 \\
\hline H34 & -1.9873632999 & 2.4699010696 & -1.9972946785 \\
\hline H35 & -4.2764413578 & 1.7905289034 & -1.0154796934 \\
\hline H36 & -5.8020992849 & -0.2009839973 & -0.7870674503 \\
\hline H37 & -4.7892373348 & -2.5207803980 & -0.8455682797 \\
\hline H38 & -2.3015825083 & -2.7291299372 & -1.1251279706 \\
\hline C39 & -0.4393924644 & -0.6366056907 & 4.8985334742 \\
\hline $\mathrm{H} 40$ & -1.1406265477 & -0.8632679233 & 2.8683987305 \\
\hline H41 & 0.3958566479 & -1.7304515542 & 3.2251663247 \\
\hline F42 & -1.2149551935 & -1.6441162201 & 5.3581406657 \\
\hline F43 & 0.7063418534 & -0.6143301002 & 5.6173564362 \\
\hline
\end{tabular}


F44

H45

$-1.0887402817$

0.1374512336

0.5427543847

1.1413999657

5.1200633092

3.1606478764 


\section{Complex 13 (gas phase)}

The total Gibbs free energy, Gtot (Htot - T*S): $\quad-1582.350242$ hartrees

$\begin{array}{lccc}\text { C1 } & 1.1245792542 & 1.1338405485 & -3.3682514890 \\ \text { C2 } & -0.0664575867 & 1.5533364325 & -2.7592057315 \\ \text { H3 } & 1.3111865417 & 1.3482778667 & -4.4242304483 \\ \text { C4 } & 2.0508508026 & 0.4112359324 & -2.6168965297 \\ \text { C5 } & -0.2864713310 & 1.2759981794 & -1.4046645575 \\ \text { H6 } & -0.8366598711 & 2.0783573219 & -3.3296326670 \\ \text { C7 } & 4.5626139976 & -2.0153444044 & 0.1942913898 \\ \text { C8 } & 1.8074422552 & 0.1563560742 & -1.2563527783 \\ \text { H9 } & 2.9710401807 & 0.0398567707 & -3.0732642928 \\ \text { C10 } & 3.8473471136 & -1.2684100645 & -0.7428213711 \\ \text { N11 } & 0.6595261066 & 0.6437141105 & -0.6549373201 \\ \text { C12 } & 4.0943720665 & -2.1167166509 & 1.5188562568 \\ \text { C13 } & 2.6537333220 & -0.6192865781 & -0.3593637093 \\ \text { C14 } & 2.9136466389 & -1.4749865597 & 1.9137566602 \\ \text { C15 } & 2.1818613079 & -0.7216666858 & 0.9821019875 \\ \text { H16 } & 5.4875142264 & -2.5193585319 & -0.1016318051 \\ \text { H17 } & 4.2169534914 & -1.1940877997 & -1.7710119300 \\ \text { H18 } & 4.6649213749 & -2.6990812324 & 2.2503140497 \\ \text { H19 } & 2.5528277284 & -1.5287511997 & 2.9451514056 \\ \text { P120 } & 0.5699017027 & 0.3304520228 & 1.3761768726 \\ \text { O21 } & 0.6595581436 & -0.0194005060 & 3.3175890910 \\ \text { H22 } & -0.0265226952 & 0.5709060578 & 3.6913735669 \\ \text { S23 } & -1.5691803365 & 2.6367545259 & 0.8370900106 \\ \text { O24 } & -0.5139577479 & 3.6444940596 & 0.5928263464 \\ \text { C25 } & -1.6263649127 & 1.6033268386 & -0.7909418340 \\ \text { C26 } & -2.5227810338 & 0.4328790660 & -0.5443586253 \\ \text { C27 } & -3.8806920046 & 0.4235874438 & -0.9063418339 \\ \text { C28 } & -4.6796808909 & -0.6794000315 & -0.5984014278 \\ \text { C29 } & -4.1286583044 & -1.7812857692 & 0.0787852243 \\ \text { C30 } & -2.7874615998 & -1.7290048666 & 0.4380104247 \\ \text { N31 } & -2.0383800230 & -0.6531529740 & 0.1184684079 \\ \text { O32 } & -1.2175792726 & 1.5589380845 & 1.8866274544 \\ \text { O33 } & -2.9763527859 & 3.0828799003 & 0.9829244688 \\ \text { H34 } & -2.1541659032 & 2.2945135194 & -1.4643069536 \\ \text { H35 } & -4.2938914729 & 1.2960092337 & -1.4164227655 \\ \text { H36 } & -5.7365662675 & -0.6813636318 & -0.8796521548 \\ \text { H37 } & -4.7297548074 & -2.6551972278 & 0.3370162270 \\ \text { H38 } & -2.2716487155 & -2.5156594469 & 0.9943070943 \\ & -1.0230289111 & -0.5668517162 & 0.5506743092\end{array}$




\section{Complex 13 (TFE)}

The total Gibbs free energy, Gtot (Htot - T*S): $\quad-1582.393020$ hartrees

$\begin{array}{lccc}\text { C1 } & 1.0979559755 & 1.1131121426 & -3.3655153184 \\ \text { C2 } & -0.0928810044 & 1.5325894440 & -2.7511861899 \\ \text { H3 } & 1.2758611318 & 1.3211256124 & -4.4256419009 \\ \text { C4 } & 2.0321702374 & 0.3933289165 & -2.6184619501 \\ \text { C5 } & -0.3089982248 & 1.2563295949 & -1.3945324455 \\ \text { H6 } & -0.8648888173 & 2.0567010481 & -3.3228218418 \\ \text { C7 } & 4.5611779297 & -2.0394062846 & 0.1696487670 \\ \text { C8 } & 1.7950162914 & 0.1484354387 & -1.2539164072 \\ \text { H9 } & 2.9483005606 & 0.0198391473 & -3.0857564027 \\ \text { C10 } & 3.8385752568 & -1.2826913598 & -0.7578898272 \\ \text { N11 } & 0.6477732032 & 0.6306476522 & -0.6467205439 \\ \text { C12 } & 4.1019061398 & -2.1524059776 & 1.4954146584 \\ \text { C13 } & 2.6534062227 & -0.6257520856 & -0.3586842602 \\ \text { C14 } & 2.9271815332 & -1.5028948359 & 1.9051699681 \\ \text { C15 } & 2.1942991481 & -0.7275532088 & 0.9896688542 \\ \text { H16 } & 5.4772911711 & -2.5517160996 & -0.1388161977 \\ \text { H17 } & 4.1955861949 & -1.2163378645 & -1.7913738527 \\ \text { H18 } & 4.6670794644 & -2.7519665957 & 2.2173864614 \\ \text { H19 } & 2.5788729867 & -1.5849478052 & 2.9396982799 \\ \text { P120 } & 0.5917241616 & 0.3438292038 & 1.3940883431 \\ \text { O21 } & 0.6925664312 & 0.0438028760 & 3.3696725397 \\ \text { H22 } & -0.0601211567 & 0.5657471903 & 3.7207848624 \\ \text { S24 } & -1.5699394541 & 2.6394813373 & 0.7975707978 \\ \text { O25 } & -0.5289713222 & 3.6689820664 & 0.5270287982 \\ \text { C26 } & -1.6574748103 & 1.5911613026 & -0.7812458057 \\ \text { C27 } & -2.5708933758 & 0.4082881805 & -0.5502726958 \\ \text { C28 } & -3.9164545192 & 0.3918045154 & -0.9463755188 \\ \text { C29 } & -4.7205589192 & -0.7162975999 & -0.6387702191 \\ \text { C30 } & -4.1755578634 & -1.8176527203 & 0.0426993573 \\ \text { C31 } & -2.8328454045 & -1.7758949174 & 0.4098688549 \\ \text { N32 } & -2.0911250435 & -0.6829963740 & 0.1128649900 \\ \text { O33 } & -1.1831357147 & 1.6219173451 & 1.8932513760 \\ \text { O34 } & -2.9630876657 & 3.1250071894 & 1.0062683891 \\ \text { H35 } & -2.1756257951 & 2.2766399706 & -1.4728217830 \\ \text { H36 } & -4.3319356579 & 1.2475712794 & -1.4875558173 \\ \text { H37 } & -5.7765271104 & -0.7180690452 & -0.9308519729 \\ \text { H38 } & -4.7809124967 & -2.6903928092 & 0.3004407004 \\ \text { H39 } & -2.3186583750 & -2.5836363937 & 0.9435230005 \\ \text { H40 } & -1.0948811827 & -0.6177929902 & 0.5109045679\end{array}$


Complex 13-TFE (gas phase)

The total Gibbs free energy, Gtot (Htot - T*S): $\quad-2034.641267$ hartrees

\begin{tabular}{|c|c|c|c|}
\hline $\mathrm{C} 1$ & 0.3243872304 & 1.0776103309 & -3.7221482402 \\
\hline $\mathrm{C} 2$ & -0.7019492391 & 1.3212766278 & -2.8007005422 \\
\hline $\mathrm{H} 3$ & 0.1604466914 & 1.2464504763 & -4.7901625221 \\
\hline $\mathrm{C} 4$ & 1.5442977979 & 0.5855148295 & -3.2625100150 \\
\hline $\mathrm{C} 5$ & -0.4733633346 & 1.1084530096 & -1.4350744955 \\
\hline H6 & -1.6868765453 & 1.6601308749 & -3.1305469243 \\
\hline $\mathrm{C} 7$ & 5.1418675455 & -1.2028631339 & -1.2748937026 \\
\hline $\mathrm{C} 8$ & 1.7479860796 & 0.3846041956 & -1.8867223104 \\
\hline H9 & 2.3498868340 & 0.3491896922 & -3.9610323053 \\
\hline $\mathrm{C} 10$ & 4.0747569932 & -0.6314530627 & -1.9715396083 \\
\hline N11 & 0.7479608696 & 0.7059576771 & -0.9878834825 \\
\hline C12 & 5.0781512997 & -1.3278495357 & 0.1260148686 \\
\hline $\mathrm{C} 13$ & 2.9369197662 & -0.1849667082 & -1.2655723023 \\
\hline C14 & 3.9559688486 & -0.8824104580 & 0.8386149472 \\
\hline $\mathrm{C} 15$ & 2.8735032893 & -0.3083872202 & 0.1536092996 \\
\hline H16 & 6.0249869745 & -1.5510000983 & -1.8182397582 \\
\hline H17 & 4.1291426675 & -0.5359995512 & -3.0609369609 \\
\hline H18 & 5.9187530536 & -1.7746972956 & 0.6675100138 \\
\hline H19 & 3.9125001298 & -0.9605720536 & 1.9288080541 \\
\hline $\operatorname{Pt} 20$ & 1.2702714754 & 0.4796999864 & 0.9766897520 \\
\hline $\mathrm{O} 21$ & 1.8501220427 & 0.1272057897 & 2.8821145787 \\
\hline $\mathrm{H} 22$ & 1.3618262129 & 0.8161590102 & 3.3792711719 \\
\hline $\mathrm{S} 23$ & -1.2932294471 & 2.3642441838 & 1.0531546510 \\
\hline $\mathrm{O} 24$ & -0.5411985666 & 3.5108455831 & 0.4963193145 \\
\hline $\mathrm{C} 25$ & -1.6285603454 & 1.2449209618 & -0.4688111012 \\
\hline $\mathrm{C} 26$ & -2.2242177422 & -0.0526243276 & -0.0045717494 \\
\hline $\mathrm{C} 27$ & -3.5882614917 & -0.3546808415 & -0.1215883811 \\
\hline $\mathrm{C} 28$ & -4.0836686456 & -1.5599636338 & 0.3889050947 \\
\hline $\mathrm{C} 29$ & -3.2231291330 & -2.4576076158 & 1.0373899899 \\
\hline C30 & -1.8769898886 & -2.1238581772 & 1.1500600411 \\
\hline N31 & -1.4327264828 & -0.9682304833 & 0.6171868283 \\
\hline O32 & -0.4630773764 & 1.4318347058 & 1.9683536212 \\
\hline O33 & -2.6472182767 & 2.5851671835 & 1.6109454576 \\
\hline H34 & -2.4255426288 & 1.8074214447 & -0.9775100396 \\
\hline H35 & -4.2502347800 & 0.3680542242 & -0.6030823713 \\
\hline H36 & -5.1489933035 & -1.7904267335 & 0.2964099331 \\
\hline H37 & -3.5870963428 & -3.3860984755 & 1.4799437790 \\
\hline H38 & -1.1260875072 & -2.6922835223 & 1.7078342761 \\
\hline H39 & -0.3993085886 & -0.6979377921 & 0.7860664876 \\
\hline H40 & 0.9887965902 & -1.2158151892 & 3.1072448130 \\
\hline O41 & 0.4041723765 & -2.0345696407 & 3.2831309389 \\
\hline $\mathrm{C} 42$ & -0.1248985556 & -1.8908232588 & 4.5758051023 \\
\hline H43 & 0.1032269752 & -2.7695818595 & 5.2123402863 \\
\hline
\end{tabular}




$\begin{array}{llll}\text { H44 } & 0.2639834304 & -0.9949673055 & 5.0972174717 \\ \text { C45 } & -1.6453507741 & -1.7580247348 & 4.5549075683 \\ \text { F46 } & -2.1363179703 & -1.5998331552 & 5.8123891301 \\ \text { F47 } & -2.0632756906 & -0.7047976480 & 3.8063196593 \\ \text { F48 } & -2.2380473807 & -2.8796796519 & 4.0281224253\end{array}$


Complex 13-TFE (TFE)

The total Gibbs free energy, Gtot (Htot - T*S): $\quad-2034.675664$ hartrees

\begin{tabular}{|c|c|c|c|}
\hline $\mathrm{C} 1$ & 0.2878666575 & 0.9254399422 & -3.6984934726 \\
\hline $\mathrm{C} 2$ & -0.7342333450 & 1.3149133977 & -2.8226131444 \\
\hline H3 & 0.1612382413 & 1.0346650640 & -4.7791059055 \\
\hline $\mathrm{C} 4$ & 1.4499993722 & 0.3649832462 & -3.1704856894 \\
\hline C5 & -0.5680515727 & 1.1444415688 & -1.4422998000 \\
\hline H6 & -1.6758856842 & 1.7197769906 & -3.2027452969 \\
\hline $\mathrm{C} 7$ & 4.8960462743 & -1.4972866699 & -1.0093566688 \\
\hline $\mathrm{C} 8$ & 1.6069288532 & 0.2484554563 & -1.7777200931 \\
\hline H9 & 2.2473993043 & 0.0175063252 & -3.8303203550 \\
\hline $\mathrm{C} 10$ & 3.8648733369 & -0.9157782064 & -1.7553377988 \\
\hline N11 & 0.6036211514 & 0.6718245234 & -0.9248122483 \\
\hline $\mathrm{C} 12$ & 4.8260171568 & -1.5016451394 & 0.3966243309 \\
\hline $\mathrm{C} 13$ & 2.7595156119 & -0.3345699923 & -1.0927591450 \\
\hline $\mathrm{C} 14$ & 3.7342014767 & -0.9241994152 & 1.0643305764 \\
\hline $\mathrm{C} 15$ & 2.6859274578 & -0.3371764631 & 0.3338327967 \\
\hline H16 & 5.7480032944 & -1.9579607383 & -1.5191299025 \\
\hline H17 & 3.9173377502 & -0.9340234173 & -2.8504603606 \\
\hline H18 & 5.6280341426 & -1.9632347387 & 0.9837949583 \\
\hline H19 & 3.6970326751 & -0.9378429249 & 2.1569850274 \\
\hline Pt20 & 1.0935757895 & 0.5597934051 & 1.0700448846 \\
\hline $\mathrm{O} 21$ & 1.7395891727 & 0.4769686272 & 2.9896594765 \\
\hline $\mathrm{H} 22$ & 1.0154461211 & 0.9044278931 & 3.4953300406 \\
\hline $\mathrm{S} 23$ & -1.4957525475 & 2.4610592502 & 0.9601442978 \\
\hline $\mathrm{O} 24$ & -0.7429668359 & 3.6326396212 & 0.4337816970 \\
\hline $\mathrm{C} 25$ & -1.7708395690 & 1.3525167167 & -0.5402466912 \\
\hline $\mathrm{C} 26$ & -2.4274265306 & 0.0458107443 & -0.1586709234 \\
\hline $\mathrm{C} 27$ & -3.7767142371 & -0.2290177348 & -0.4185969454 \\
\hline $\mathrm{C} 28$ & -4.3048195905 & -1.4954611169 & -0.1217204331 \\
\hline C29 & -3.4773425558 & -2.4863141535 & 0.4338135249 \\
\hline $\mathrm{C} 30$ & -2.1517993814 & -2.1659349489 & 0.7173259938 \\
\hline N31 & -1.6782484950 & -0.9315626311 & 0.4280531383 \\
\hline $\mathrm{O} 32$ & -0.6902333777 & 1.5795574792 & 1.9351346685 \\
\hline $\mathrm{O} 33$ & -2.8608301197 & 2.7153419459 & 1.4945193678 \\
\hline H34 & -2.5133162628 & 1.9392155553 & -1.1066644453 \\
\hline H35 & -4.3979271854 & 0.5511925209 & -0.8689138522 \\
\hline H36 & -5.3577935110 & -1.7164003628 & -0.3325061527 \\
\hline H37 & -3.8495299220 & -3.4917072620 & 0.6509228291 \\
\hline H38 & -1.4449955706 & -2.8585194186 & 1.1782789881 \\
\hline H39 & -0.6735595785 & -0.6895001468 & 0.6968169298 \\
\hline $\mathrm{H} 40$ & 1.7091329536 & -1.0909206091 & 3.5478201806 \\
\hline O41 & 1.6648625890 & -2.0278012342 & 3.9310254483 \\
\hline $\mathrm{C} 42$ & 0.7006431167 & -2.0027500375 & 4.9538888098 \\
\hline H43 & 0.7800366234 & -2.9232778211 & 5.5629792914 \\
\hline
\end{tabular}




$\begin{array}{llll}\text { H44 } & 0.8076934419 & -1.1385223410 & 5.6433834963 \\ \text { C45 } & -0.7261266902 & -1.9553572131 & 4.4058302120 \\ \text { F46 } & -1.6406407544 & -2.0166789437 & 5.4138883980 \\ \text { F47 } & -0.9782356341 & -0.8120214384 & 3.7024968262 \\ \text { F48 } & -0.9840484555 & -2.9971487266 & 3.5571263927\end{array}$


Complex 14 (gas phase)

The total Gibbs free energy, Gtot (Htot - T*S): $\quad-1958.300659$ hartrees

\begin{tabular}{|c|c|c|c|}
\hline $\mathrm{C} 1$ & 0.8295677167 & 0.0477763565 & -4.4329338180 \\
\hline $\mathrm{C} 2$ & -0.2739732100 & 0.7368092350 & -3.9132562536 \\
\hline $\mathrm{H} 3$ & 0.9267951691 & -0.1109930981 & -5.5105787179 \\
\hline $\mathrm{C} 4$ & 1.7833797990 & -0.4588184557 & -3.5527762975 \\
\hline $\mathrm{C} 5$ & -0.3717330366 & 0.9472788339 & -2.5320113375 \\
\hline H6 & -1.0665304255 & 1.1075992013 & -4.5676744482 \\
\hline $\mathrm{C} 7$ & 4.3413529982 & -2.1579899867 & -0.2974279365 \\
\hline $\mathrm{C} 8$ & 1.6558021772 & -0.2383630936 & -2.1706593621 \\
\hline H9 & 2.6346225057 & -1.0340424918 & -3.9234952545 \\
\hline $\mathrm{C} 10$ & 3.6198399449 & -1.6394374140 & -1.3741281212 \\
\hline N11 & 0.6038512157 & 0.5192320972 & -1.6847361213 \\
\hline $\mathrm{C} 12$ & 3.9734699030 & -1.8270988972 & 1.0209055288 \\
\hline $\mathrm{C} 13$ & 2.5237190141 & -0.7827610010 & -1.1343263328 \\
\hline C14 & 2.8907383682 & -0.9743365269 & 1.2728059132 \\
\hline $\mathrm{C} 15$ & 2.1605527352 & -0.4402479588 & 0.1997808726 \\
\hline H16 & 5.1915897653 & -2.8217901655 & -0.4802140652 \\
\hline H17 & 3.9094395850 & -1.9041018896 & -2.3967093805 \\
\hline H18 & 4.5446659872 & -2.2376450626 & 1.8604535245 \\
\hline H19 & 2.6015143103 & -0.6983470744 & 2.2909091112 \\
\hline Pt20 & 0.7091814912 & 0.8753917561 & 0.3386317193 \\
\hline $\mathrm{S} 21$ & -1.3177578280 & 3.0904547753 & -0.8107283849 \\
\hline $\mathrm{O} 22$ & -0.2321067088 & 3.8454827603 & -1.4733115595 \\
\hline $\mathrm{C} 23$ & -1.6197873056 & 1.5954566468 & -1.9794969037 \\
\hline $\mathrm{C} 24$ & -2.5848487862 & 0.6618509444 & -1.3181158868 \\
\hline $\mathrm{C} 25$ & -3.9345838397 & 0.5702936482 & -1.6961067656 \\
\hline $\mathrm{C} 26$ & -4.7985524988 & -0.2898495972 & -1.0143941769 \\
\hline $\mathrm{C} 27$ & -4.3211859143 & -1.0546646282 & 0.0625989714 \\
\hline $\mathrm{C} 28$ & -2.9857087182 & -0.9267983008 & 0.4252655637 \\
\hline N29 & -2.1730646874 & -0.0985085435 & -0.2663433040 \\
\hline $\mathrm{O} 30$ & -0.9187968987 & 2.3952731267 & 0.5080179363 \\
\hline $\mathrm{O} 31$ & -2.6656553211 & 3.6981798115 & -0.7043575866 \\
\hline H32 & -2.1482973948 & 2.0757983867 & -2.8160773626 \\
\hline H33 & -4.2904676766 & 1.1852427261 & -2.5252973055 \\
\hline H34 & -5.8472575700 & -0.3608796307 & -1.3168444206 \\
\hline H35 & -4.9734719920 & -1.7277885472 & 0.6221636282 \\
\hline H36 & -2.5258777378 & -1.4382465816 & 1.2724944118 \\
\hline $\mathrm{H} 48$ & -1.1421569943 & 0.0289030957 & 0.0725481900 \\
\hline $\mathrm{O} 38$ & 1.0650058546 & 1.1456027878 & 2.2944631522 \\
\hline C39 & -0.0406712838 & 1.2513942601 & 3.1399890241 \\
\hline H41 & 0.2359956257 & 1.8483322996 & 4.0334691766 \\
\hline H42 & -0.9253010288 & 1.7353484636 & 2.6815140647 \\
\hline $\mathrm{C} 42$ & -0.4865787608 & -0.1112140995 & 3.6691313354 \\
\hline F43 & -0.8908868930 & -0.9603630053 & 2.6541091611 \\
\hline
\end{tabular}




$\begin{array}{lrrr}\text { F44 } & 0.4987261818 & -0.7632993441 & 4.3314524934 \\ \text { F45 } & -1.5490192118 & 0.0101608144 & 4.5151050034\end{array}$




\section{Complex 14 (TFE)}

The total Gibbs free energy, Gtot (Htot - T*S): $\quad-1958.34045$ hartrees

$\begin{array}{lccc}\text { C1 } & 0.8134282238 & 0.0358053950 & -4.4315110418 \\ \text { C2 } & -0.2874899839 & 0.7297443766 & -3.9092006438 \\ \text { H3 } & 0.9110892893 & -0.1220477026 & -5.5100268796 \\ \text { C4 } & 1.7711158061 & -0.4736124175 & -3.5549560502 \\ \text { C5 } & -0.3812610743 & 0.9418822539 & -2.5262598473 \\ \text { H6 } & -1.0747782068 & 1.1035980534 & -4.5699711314 \\ \text { C7 } & 4.3393841536 & -2.1806253730 & -0.2938800332 \\ \text { C8 } & 1.6469358780 & -0.2501795365 & -2.1718015522 \\ \text { H9 } & 2.6184783283 & -1.0516038227 & -3.9357683893 \\ \text { C10 } & 3.6154792109 & -1.6579536399 & -1.3719694648 \\ \text { N11 } & 0.5962352815 & 0.5057120784 & -1.6802119973 \\ \text { C12 } & 3.9725192737 & -1.8513314380 & 1.0248158335 \\ \text { C13 } & 2.5227724582 & -0.7931205204 & -1.1331513523 \\ \text { C14 } & 2.8913792655 & -0.9905775818 & 1.2739671805 \\ \text { C15 } & 2.1643259761 & -0.4435784863 & 0.2033345665 \\ \text { H16 } & 5.1894598047 & -2.8453886484 & -0.4783009301 \\ \text { H17 } & 3.9028825026 & -1.9307738336 & -2.3937639112 \\ \text { H18 } & 4.5385124227 & -2.2691346361 & 1.8658293566 \\ \text { H19 } & 2.6021623664 & -0.7295470031 & 2.2963016426 \\ \text { P120 } & 0.7217655906 & 0.8867761447 & 0.3439907338 \\ \text { S21 } & -1.3216526760 & 3.0827160733 & -0.8373649633 \\ \text { O22 } & -0.2505757221 & 3.8739577047 & -1.5051033069 \\ \text { C23 } & -1.6367867885 & 1.5944982507 & -1.9722676373 \\ \text { C24 } & -2.6202656575 & 0.6498265396 & -1.3130644631 \\ \text { C25 } & -3.9635453732 & 0.5501684493 & -1.7050107076 \\ \text { C26 } & -4.8361566333 & -0.3112314551 & -1.0234751209 \\ \text { C27 } & -4.3647320914 & -1.0793619848 & 0.0520265767 \\ \text { C28 } & -3.0236330680 & -0.9685233550 & 0.4080752165 \\ \text { N29 } & -2.2085794475 & -0.1271106020 & -0.2706998806 \\ \text { O30 } & -0.8874541050 & 2.4431448816 & 0.4984845073 \\ \text { O31 } & -2.6522251524 & 3.7368500135 & -0.6943430154 \\ \text { H32 } & -2.1625529710 & 2.0709631478 & -2.8161781094 \\ \text { H33 } & -4.3242113425 & 1.1504256113 & -2.5438072599 \\ \text { H34 } & -5.8855884908 & -0.3808771849 & -1.3284390837 \\ \text { H35 } & -5.0205379351 & -1.7502482761 & 0.6144084219 \\ \text { H36 } & -2.5694320217 & -1.5161705166 & 1.2363781259 \\ \text { H48 } & -1.1939372865 & -0.0151732402 & 0.0627609521 \\ \text { O38 } & 1.0776638762 & 1.2123914568 & 2.3170679781 \\ \text { H39 } & -0.0411874376 & 1.2551682339 & 3.1589867201 \\ \text { H42 } & 0.1936102334 & 1.8419617916 & 4.0717919464 \\ & -0.9374978378 & 1.7157295024 & 2.6999014833 \\ \text { H4 } & -0.4723052572 & -0.1216484367 & 3.6657400029 \\ \text { H3 } 0.8636555881 & -0.9635192428 & 2.6485554469\end{array}$


F44

F45
0.5129882512

$-1.5377737720$
$-0.7755073347$

$-0.0073447764$
4.3359042038

4.5110910173 
$\mathrm{TS}_{7-10}$ (gas phase)

The total Gibbs free energy, Gtot (Htot - T*S): $\quad$-2034.628874 hartrees

\begin{tabular}{|c|c|c|c|}
\hline $\mathrm{C} 1$ & 0.0732654093 & 0.3486561493 & -4.4763816790 \\
\hline $\mathrm{C} 2$ & -0.8080137507 & 0.9948588791 & -3.6027245848 \\
\hline $\mathrm{H} 3$ & 0.0924569657 & 0.6170090395 & -5.5362879715 \\
\hline $\mathrm{C} 4$ & 0.9710987482 & -0.5956779523 & -3.9722006851 \\
\hline $\mathrm{C} 5$ & -0.8449133259 & 0.6316804636 & -2.2471558972 \\
\hline H6 & -1.4598299726 & 1.7992110145 & -3.9511892879 \\
\hline $\mathrm{C} 7$ & 3.9945356650 & -2.9243678428 & -1.5769605158 \\
\hline $\mathrm{C} 8$ & 0.9325076498 & -0.9324384363 & -2.6123237028 \\
\hline H9 & 1.7326729706 & -1.0453002394 & -4.6132602715 \\
\hline $\mathrm{C} 10$ & 3.0318720230 & -2.3484941894 & -2.4128385678 \\
\hline N11 & -0.0559093182 & -0.3919029686 & -1.8159575095 \\
\hline $\mathrm{C} 12$ & 3.8492732653 & -2.8354990349 & -0.1827580219 \\
\hline $\mathrm{C} 13$ & 1.9140543415 & -1.7010228909 & -1.8540991982 \\
\hline C14 & 2.7300765184 & -2.2004037303 & 0.3827204300 \\
\hline $\mathrm{C} 15$ & 1.7299708594 & -1.6467783538 & -0.4359063879 \\
\hline H16 & 4.8648290325 & -3.4262273507 & -2.0090294163 \\
\hline H17 & 3.1584089055 & -2.3981771514 & -3.4994673645 \\
\hline H18 & 4.6168845084 & -3.2610432173 & 0.4721704623 \\
\hline H19 & 2.6481838795 & -2.1413119410 & 1.4743345667 \\
\hline Pt20 & -0.0339007039 & -0.8975310941 & 0.0933278240 \\
\hline $\mathrm{S} 21$ & -0.5216021552 & 2.5334385827 & -0.0903167926 \\
\hline $\mathrm{O} 22$ & 0.8663650094 & 2.3299550874 & -0.5881582119 \\
\hline $\mathrm{C} 23$ & -1.6688365909 & 1.4065583453 & -1.2650241551 \\
\hline $\mathrm{C} 24$ & -2.6204469650 & 0.6459450577 & -0.4065608070 \\
\hline $\mathrm{C} 25$ & -3.9802729434 & 0.9938316539 & -0.3423740278 \\
\hline $\mathrm{C} 26$ & -4.8351976366 & 0.2896653324 & 0.5077993387 \\
\hline $\mathrm{C} 27$ & -4.3093469446 & -0.7541440085 & 1.2796208574 \\
\hline $\mathrm{C} 28$ & -2.9504087890 & -1.0526479870 & 1.1713935325 \\
\hline N29 & -2.1231621409 & -0.3676894102 & 0.3489788002 \\
\hline $\mathrm{O} 30$ & -0.7515001720 & 1.9925975865 & 1.3243246873 \\
\hline $\mathrm{O} 31$ & -1.1530418227 & 3.8615898591 & -0.2892974742 \\
\hline H32 & -2.2141757582 & 2.1864318343 & -1.8131186213 \\
\hline H33 & -4.3479491334 & 1.8209460910 & -0.9548239282 \\
\hline H34 & -5.8955767700 & 0.5519302348 & 0.5676483222 \\
\hline H35 & -4.9364685449 & -1.3337524003 & 1.9611361658 \\
\hline H36 & -2.4770310526 & -1.8477691169 & 1.7535936554 \\
\hline $\mathrm{O} 37$ & -0.4675638519 & -2.4415194946 & 2.3103496640 \\
\hline $\mathrm{O} 38$ & 0.5264891584 & -0.0066572303 & 2.2316455008 \\
\hline H39 & 0.0140435780 & 0.8562615665 & 1.9057669391 \\
\hline $\mathrm{H} 40$ & 1.4654100387 & 0.1966888048 & 2.0583586734 \\
\hline H41 & 0.0501665352 & -1.6480074986 & 2.6130753137 \\
\hline $\mathrm{C} 42$ & 0.2725826809 & -3.6371746311 & 2.5010913606 \\
\hline $\mathrm{C} 43$ & 0.9693237620 & -3.6550308070 & 3.8549061675 \\
\hline
\end{tabular}




$\begin{array}{llll}\text { H44 } & -0.4311601210 & -4.4831735276 & 2.4564934590 \\ \text { H45 } & 1.0464162892 & -3.7816772042 & 1.7245059036 \\ \text { F46 } & 1.7112315724 & -4.7810656968 & 3.9948293966 \\ \text { F47 } & 1.8141976765 & -2.5787167871 & 3.9586850352 \\ \text { F48 } & 0.1017669298 & -3.5839441535 & 4.8900891449\end{array}$

$\mathrm{TS}_{7-10}$ (TFE)

The total Gibbs free energy, Gtot (Htot - T*S): $\quad-2034.628874$ hartrees

Gibbs solvation energy $-19.2679 \mathrm{kcal} / \mathrm{mol}$

This TS could not be located in TFE; the Gibbs energy is calculated using Gsolv corrections to the gas phase energy above.

Other Gibbs solvation energies used for this and similar calculations;

7 ,

$11,-21.6583 \mathrm{kcal} / \mathrm{mol}$

13-TFE, $\quad-23.1329 \mathrm{kcal} / \mathrm{mol}$

TFE, $\quad-4.7999 \mathrm{kcal} / \mathrm{mol}$

$\mathbf{H}_{2} \mathbf{O}, \quad-7.3771 \mathrm{kcal} / \mathrm{mol}$ 
TS $_{7-11}$ (gas phase)

The total Gibbs free energy, Gtot (Htot - T*S): $\quad-1582.350618$ hartrees

$\begin{array}{lccc}\text { C1 } & 1.1785267488 & 1.1942447245 & -3.3312536204 \\ \text { C2 } & -0.0298498510 & 1.5543908568 & -2.7213780199 \\ \text { H3 } & 1.3959078382 & 1.5213377403 & -4.3520505979 \\ \text { C4 } & 2.1069735757 & 0.4261033298 & -2.6273090252 \\ \text { C5 } & -0.3113976140 & 1.1296640084 & -1.4146738032 \\ \text { H6 } & -0.7649804067 & 2.1670818731 & -3.2478375713 \\ \text { C7 } & 4.6662245920 & -1.9533403120 & 0.2342977053 \\ \text { C8 } & 1.8201367809 & 0.0228453138 & -1.3141169647 \\ \text { H9 } & 3.0635259007 & 0.1490331172 & -3.0758093869 \\ \text { C10 } & 3.9419638146 & -1.2405642432 & -0.7231699810 \\ \text { N11 } & 0.6054868249 & 0.3684781544 & -0.7542565931 \\ \text { C12 } & 4.1172896879 & -2.1580862405 & 1.5145056969 \\ \text { C13 } & 2.6712140481 & -0.7233039223 & -0.4028690116 \\ \text { C14 } & 2.8553207472 & -1.6482178723 & 1.8472802613 \\ \text { C15 } & 2.1124616241 & -0.9130516668 & 0.9026541398 \\ \text { H16 } & 5.6529542896 & -2.3554974504 & -0.0113978907 \\ \text { H17 } & 4.3633094299 & -1.0908061680 & -1.7232253617 \\ \text { H18 } & 4.6827734670 & -2.7250439032 & 2.2616626728 \\ \text { H19 } & 2.4454069017 & -1.8368558741 & 2.8458445007 \\ \text { P120 } & 0.3186426857 & -0.1533288046 & 1.1263946884 \\ \text { O21 } & 0.0027809349 & -0.3533627942 & 3.2702331768 \\ \text { H22 } & 0.8400362530 & -0.0289074976 & 3.6571207550 \\ \text { H23 } & -0.5943099526 & 0.4471251327 & 3.2697559287 \\ \text { S24 } & -1.4285408295 & 2.5913043037 & 0.8199536929 \\ \text { O25 } & -0.2461140717 & 3.4446517158 & 0.5474881399 \\ \text { C26 } & -1.6142236724 & 1.4956434735 & -0.7527303402 \\ \text { C27 } & -2.5088964956 & 0.3271766693 & -0.4234462306 \\ \text { C28 } & -3.8130912876 & 0.2299567110 & -0.9380725963 \\ \text { C29 } & -4.6027532707 & -0.8677617795 & -0.5815742059 \\ \text { C30 } & -4.0709340529 & -1.8389536525 & 0.2773094922 \\ \text { C31 } & -2.7652922650 & -1.6624360118 & 0.7502448747 \\ \text { N32 } & -2.0071694402 & -0.6043001191 & 0.4140374741 \\ \text { O33 } & -1.2061806483 & 1.5589048901 & 1.9439018809 \\ \text { O34 } & -2.7621178442 & 3.2344358850 & 0.9221562340 \\ \text { H35 } & -2.1481569943 & 2.1810093482 & -1.4273294706 \\ \text { H36 } & -4.1962274182 & 1.0098560150 & -1.6017041161 \\ \text { H37 } & -5.6209204012 & -0.9642966494 & -0.9705345187 \\ & -4.6514826832 & -2.7150745089 & 0.5773729301 \\ \text { H39 } & -2.2978414387 & -2.3890436586 & 1.4237588660\end{array}$


TS $_{7-11}$ (TFE)

The total Gibbs free energy, Gtot $($ Htot $-\mathrm{T} * \mathrm{~S})$ : $\quad-1582.388461$ hartrees

$\begin{array}{lccc}\text { C1 } & 1.2107947166 & 1.2630509424 & -3.3097628875 \\ \text { C2 } & -0.0091988766 & 1.6031867701 & -2.7090138551 \\ \text { H3 } & 1.4471694231 & 1.6211956769 & -4.3173942033 \\ \text { C4 } & 2.1306191155 & 0.4811229936 & -2.6070968771 \\ \text { C5 } & -0.3074086150 & 1.1437190227 & -1.4151792008 \\ \text { H6 } & -0.7304895148 & 2.2317162724 & -3.2408740530 \\ \text { C7 } & 4.6617072008 & -1.9804425309 & 0.2250802473 \\ \text { C8 } & 1.8244068138 & 0.0450096651 & -1.3060836607 \\ \text { H9 } & 3.0975831847 & 0.2328169243 & -3.0539324879 \\ \text { C10 } & 3.9481636067 & -1.2373476642 & -0.7216840481 \\ \text { N11 } & 0.5936104055 & 0.3599980188 & -0.7530868162 \\ \text { C12 } & 4.1007129559 & -2.2173623315 & 1.4938614597 \\ \text { C13 } & 2.6787112028 & -0.7100149385 & -0.3979708733 \\ \text { C14 } & 2.8450847819 & -1.6890490406 & 1.8331834098 \\ \text { C15 } & 2.1214438449 & -0.9093717055 & 0.9085250543 \\ \text { H16 } & 5.6502649323 & -2.3815091979 & -0.0194314288 \\ \text { H17 } & 4.3840051075 & -1.0732493610 & -1.7133074682 \\ \text { H18 } & 4.6486908242 & -2.8197631430 & 2.2277418588 \\ \text { H19 } & 2.4269902909 & -1.9140803139 & 2.8201130571 \\ \text { P120 } & 0.2999339084 & -0.1914983821 & 1.1415498107 \\ \text { O21 } & 0.0878614220 & -0.4310528716 & 3.3230387681 \\ \text { H22 } & 0.9524057628 & -0.2928568586 & 3.7720755459 \\ \text { H23 } & -0.4204659005 & 0.3867241283 & 3.5432279209 \\ \text { S24 } & -1.4187695569 & 2.6740523124 & 0.7450289465 \\ \text { O25 } & -0.2385452297 & 3.5382280732 & 0.4243114873 \\ \text { C26 } & -1.6182392198 & 1.5130351301 & -0.7601001900 \\ \text { C27 } & -2.5002851802 & 0.3394691894 & -0.3926636397 \\ \text { C28 } & -3.7513005656 & 0.1343783171 & -1.0029244587 \\ \text { C29 } & -4.5242324653 & -0.9716575622 & -0.6258718301 \\ \text { C30 } & -4.0231224438 & -1.8496229616 & 0.3445381413 \\ \text { C31 } & -2.7658354627 & -1.5784614373 & 0.8995184968 \\ \text { N32 } & -2.0249602223 & -0.5052844654 & 0.5510887377 \\ \text { O33 } & -1.1948764556 & 1.7690046510 & 1.9494929529 \\ \text { O34 } & -2.7433772103 & 3.3743784258 & 0.7844787525 \\ \text { H35 } & -2.1661027904 & 2.1607399522 & -1.4614940875 \\ \text { H36 } & -4.1135809290 & 0.8267587573 & -1.7684478622 \\ \text { H37 } & -5.5018993277 & -1.1493723682 & -1.0867921521 \\ \text { H38 } & -4.5916247667 & -2.7272028456 & 0.6674929571 \\ \text { H39 } & -2.3245789384 & -2.2424608333 & 1.6487264677\end{array}$


$\mathrm{TS}_{10-12}$ (gas phase)

The total Gibbs free energy, Gtot (Htot - T*S): $\quad-1958.288122$ hartrees

\begin{tabular}{|c|c|c|c|}
\hline $\mathrm{C} 1$ & 1.1204530314 & 1.3154499181 & -3.3824094949 \\
\hline $\mathrm{C} 2$ & -0.0494549138 & 1.6858241292 & -2.7067116618 \\
\hline $\mathrm{H} 3$ & 1.3160129951 & 1.6986320091 & -4.3880438472 \\
\hline $\mathrm{C} 4$ & 2.0447795224 & 0.4749071608 & -2.7600538099 \\
\hline $\mathrm{C} 5$ & -0.3052897453 & 1.1840107094 & -1.4221175730 \\
\hline H6 & -0.7725718331 & 2.3648019581 & -3.1640108070 \\
\hline $\mathrm{C} 7$ & 4.6886216604 & -1.9927935122 & -0.0460539369 \\
\hline $\mathrm{C} 8$ & 1.7874309053 & 0.0019446070 & -1.4637917602 \\
\hline H9 & 2.9796547789 & 0.2019916623 & -3.2543074204 \\
\hline $\mathrm{C} 10$ & 3.9224824119 & -1.2885383957 & -0.9767126863 \\
\hline N11 & 0.5950155205 & 0.3363264675 & -0.8526314662 \\
\hline $\mathrm{C} 12$ & 4.2000636813 & -2.1856690363 & 1.2605135983 \\
\hline $\mathrm{C} 13$ & 2.6609272285 & -0.7816690374 & -0.6066188835 \\
\hline C14 & 2.9475729816 & -1.6875864152 & 1.6447363575 \\
\hline $\mathrm{C} 15$ & 2.1564833514 & -0.9859912699 & 0.7171742654 \\
\hline H16 & 5.6677323648 & -2.3883984946 & -0.3301691986 \\
\hline H17 & 4.3047992197 & -1.1339095665 & -1.9913718553 \\
\hline H18 & 4.8096288040 & -2.7285386614 & 1.9907063418 \\
\hline H19 & 2.5885784592 & -1.8331992664 & 2.6682865830 \\
\hline Pt20 & 0.3475613182 & -0.2906154304 & 1.0022248693 \\
\hline $\mathrm{O} 21$ & 0.1696924784 & -0.5093815645 & 3.1572768046 \\
\hline $\mathrm{H} 23$ & -0.1605049446 & 0.4376782205 & 3.1991401071 \\
\hline $\mathrm{S} 24$ & -1.2738373832 & 2.5256375247 & 0.9683049063 \\
\hline $\mathrm{O} 25$ & -0.0169301457 & 3.2824650875 & 0.7519869443 \\
\hline $\mathrm{C} 26$ & -1.5626368321 & 1.5635671984 & -0.6826719723 \\
\hline $\mathrm{C} 27$ & -2.5026809253 & 0.4145938745 & -0.4287844427 \\
\hline $\mathrm{C} 28$ & -3.8233440195 & 0.4255560232 & -0.9112009301 \\
\hline C29 & -4.6495758047 & -0.6738333123 & -0.6594399730 \\
\hline $\mathrm{C} 30$ & -4.1338793568 & -1.7611802191 & 0.0588959609 \\
\hline C31 & -2.8116203705 & -1.6866948254 & 0.5110869431 \\
\hline N32 & -2.0186561667 & -0.6225245748 & 0.2882107370 \\
\hline $\mathrm{O} 33$ & -1.1561157811 & 1.4015236825 & 2.0192144763 \\
\hline $\mathrm{O} 34$ & -2.5445050270 & 3.2775969348 & 1.1144894377 \\
\hline H35 & -2.0803224960 & 2.3277809171 & -1.2806572641 \\
\hline H36 & -4.1886915726 & 1.2895921781 & -1.4724890422 \\
\hline H37 & -5.6807127353 & -0.6852285192 & -1.0252241519 \\
\hline H38 & -4.7383331674 & -2.6480829657 & 0.2663737785 \\
\hline H39 & -2.3575883137 & -2.5129747056 & 1.0698311024 \\
\hline C39 & -0.9050477607 & -1.3384273141 & 3.6413223222 \\
\hline H41 & -1.8668127317 & -1.0371321094 & 3.1949425905 \\
\hline H42 & -0.6677270784 & -2.3781288296 & 3.3734471149 \\
\hline $\mathrm{C} 42$ & -0.9927034039 & -1.2160752077 & 5.1595263621 \\
\hline F43 & 0.1350399146 & -1.6545209545 & 5.7643062200 \\
\hline
\end{tabular}


F44

F45
$-1.1921203438$

$-2.0363136592$
0.0742723402

$-1.9580032240$
5.5267708212

5.6110234768 
$\mathrm{TS}_{10-12}$ (TFE)

The total Gibbs free energy, Gtot $($ Htot $-\mathrm{T} * \mathrm{~S})$ : $\quad-1958.320483$ hartrees

\begin{tabular}{|c|c|c|c|}
\hline $\mathrm{C} 1$ & 1.1055079684 & 1.2837014032 & -3.3904245089 \\
\hline $\mathrm{C} 2$ & -0.0641025502 & 1.6872214960 & -2.7297301396 \\
\hline $\mathrm{H} 3$ & 1.3078288002 & 1.6275462504 & -4.4099817377 \\
\hline $\mathrm{C} 4$ & 2.0139346242 & 0.4472625238 & -2.7378805574 \\
\hline $\mathrm{C} 5$ & -0.3250933423 & 1.2328174948 & -1.4282262683 \\
\hline H6 & -0.7862861459 & 2.3474627863 & -3.2186983515 \\
\hline $\mathrm{C} 7$ & 4.5536982044 & -2.1462004269 & -0.0467118233 \\
\hline $\mathrm{C} 8$ & 1.7473032618 & 0.0176062180 & -1.4281730120 \\
\hline H9 & 2.9400970755 & 0.1351782518 & -3.2290754275 \\
\hline $\mathrm{C} 10$ & 3.8243457376 & -1.3788667139 & -0.9612698944 \\
\hline N11 & 0.5692158854 & 0.4053538186 & -0.8155413338 \\
\hline $\mathrm{C} 12$ & 4.0612936096 & -2.3361638570 & 1.2598768767 \\
\hline $\mathrm{C} 13$ & 2.5974886757 & -0.7993930943 & -0.5731927208 \\
\hline C14 & 2.8440424704 & -1.7640231387 & 1.6602928223 \\
\hline $\mathrm{C} 15$ & 2.0942754062 & -0.9903825247 & 0.7531430246 \\
\hline H16 & 5.5039925440 & -2.5992044348 & -0.3461123294 \\
\hline H17 & 4.2076077836 & -1.2373016925 & -1.9782276394 \\
\hline H18 & 4.6341136991 & -2.9376286483 & 1.9757900455 \\
\hline H19 & 2.4743150001 & -1.9199753837 & 2.6785698752 \\
\hline Pt20 & 0.3220535341 & -0.1987156298 & 1.0581911821 \\
\hline $\mathrm{O} 21$ & 0.2622940037 & -0.6346793034 & 3.1746062678 \\
\hline $\mathrm{H} 23$ & 0.3663294331 & 0.2617557234 & 3.5735373951 \\
\hline $\mathrm{S} 24$ & -1.4057131056 & 2.6763852740 & 0.8254496347 \\
\hline $\mathrm{O} 25$ & -0.3289495280 & 3.6535196315 & 0.4733794189 \\
\hline $\mathrm{C} 26$ & -1.6151117478 & 1.6113774148 & -0.7328460872 \\
\hline $\mathrm{C} 27$ & -2.5024022518 & 0.4141038559 & -0.4595659889 \\
\hline $\mathrm{C} 28$ & -3.7338710719 & 0.2574322380 & -1.1213634988 \\
\hline C29 & -4.4833688066 & -0.9049646042 & -0.9008904064 \\
\hline $\mathrm{C} 30$ & -3.9799412651 & -1.8784466993 & -0.0264620011 \\
\hline C31 & -2.7524263671 & -1.6376077345 & 0.6012957395 \\
\hline N32 & -2.0298773296 & -0.5146995597 & 0.4022320438 \\
\hline $\mathrm{O} 33$ & -1.0214380904 & 1.7197218771 & 1.9501468312 \\
\hline $\mathrm{O} 34$ & -2.7709309523 & 3.2583319696 & 1.0230827791 \\
\hline H35 & -2.1516768887 & 2.3053651855 & -1.4001214001 \\
\hline H36 & -4.0882008679 & 1.0324984630 & -1.8087112358 \\
\hline H37 & -5.4400080709 & -1.0548721742 & -1.4134323179 \\
\hline H38 & -4.5206037650 & -2.8107970989 & 0.1644369229 \\
\hline H39 & -2.3171874962 & -2.3805125171 & 1.2782631054 \\
\hline C39 & -0.9486195656 & -1.2416224104 & 3.6877280052 \\
\hline H41 & -1.8320587679 & -0.6109541839 & 3.4892244556 \\
\hline H42 & -1.0456943645 & -2.2188778350 & 3.1927200255 \\
\hline $\mathrm{C} 42$ & -0.7979977495 & -1.4635060260 & 5.1867797676 \\
\hline F43 & 0.2233359857 & -2.3055601912 & 5.4733886690 \\
\hline
\end{tabular}


F44

F45
$-0.5529739459$

$-1.9402368615$
$-0.2846167425$

$-1.9918070408$
5.8222380154

5.6866610998 
$\mathrm{TS}_{11-12}$ (gas phase)

The total Gibbs free energy, Gtot (Htot - T*S): $\quad-2034.615165$ hartrees

\begin{tabular}{|c|c|c|c|}
\hline $\mathrm{C} 1$ & 1.2325968615 & 1.1493346080 & -3.9284361277 \\
\hline $\mathrm{C} 2$ & 0.0547409341 & 1.5170313464 & -3.2707814901 \\
\hline $\mathrm{H} 3$ & 1.4552581060 & 1.5387818386 & -4.9255543910 \\
\hline $\mathrm{C} 4$ & 2.1049670754 & 0.2616182003 & -3.3013385286 \\
\hline $\mathrm{C} 5$ & -0.2331123290 & 1.0194906212 & -1.9928537484 \\
\hline H6 & -0.6722720370 & 2.1782114298 & -3.7475892209 \\
\hline $\mathrm{C} 7$ & 4.4135295105 & -2.7402281580 & -0.8826183900 \\
\hline $\mathrm{C} 8$ & 1.8122636248 & -0.2124639426 & -2.0146017701 \\
\hline H9 & 3.0212114450 & -0.0707166093 & -3.7939796421 \\
\hline $\mathrm{C} 10$ & 3.7748803191 & -1.7997583303 & -1.6960921476 \\
\hline N11 & 0.6651035420 & 0.2067758758 & -1.3633687627 \\
\hline $\mathrm{C} 12$ & 3.8757559333 & -3.0563474919 & 0.3771826363 \\
\hline C13 & 2.5993990466 & -1.1683233457 & -1.2473616248 \\
\hline $\mathrm{C} 14$ & 2.7044458146 & -2.4304740844 & 0.8325724748 \\
\hline $\mathrm{C} 15$ & 2.0528912576 & -1.4728758097 & 0.0330990090 \\
\hline H16 & 5.3265204167 & -3.2324917556 & -1.2292010907 \\
\hline H17 & 4.1931019710 & -1.5638188059 & -2.6801253358 \\
\hline H18 & 4.3719659709 & -3.8014059463 & 1.0081212769 \\
\hline H19 & 2.2935312471 & -2.6976208643 & 1.8133563187 \\
\hline Pt20 & 0.4643527581 & -0.4249384352 & 0.5157141511 \\
\hline $\mathrm{S} 21$ & -1.5142800938 & 1.9861581675 & 0.3718468615 \\
\hline $\mathrm{O} 22$ & -0.3529477820 & 2.9054770380 & 0.4049978994 \\
\hline $\mathrm{C} 23$ & -1.5809428234 & 1.3218733305 & -1.3867971344 \\
\hline $\mathrm{C} 24$ & -2.5652046172 & 0.1635772881 & -1.5153178606 \\
\hline $\mathrm{C} 25$ & -3.9324908739 & 0.3641216527 & -1.2391895081 \\
\hline $\mathrm{C} 26$ & -4.8063688918 & -0.7173170137 & -1.3819578395 \\
\hline $\mathrm{C} 27$ & -4.2971349275 & -1.9549722899 & -1.8001453238 \\
\hline $\mathrm{C} 28$ & -2.9236426427 & -2.0484960476 & -2.0572281467 \\
\hline N29 & -2.0655441071 & -1.0202935848 & -1.9228399034 \\
\hline $\mathrm{O} 30$ & -1.2807434880 & 0.6819248636 & 1.2017770329 \\
\hline $\mathrm{O} 31$ & -2.8649119880 & 2.5349454703 & 0.6435720561 \\
\hline H32 & -1.9942533657 & 2.1962802486 & -1.9171399350 \\
\hline H33 & -4.2797939626 & 1.3405574247 & -0.8922552731 \\
\hline H34 & -5.8735966252 & -0.5936304000 & -1.1719919319 \\
\hline H35 & -4.9470725150 & -2.8251001803 & -1.9305714880 \\
\hline H36 & -2.4822021980 & -2.9954208922 & -2.3942619707 \\
\hline O49 & -0.6846692417 & -1.6709264312 & 2.2896899810 \\
\hline $\mathrm{H} 50$ & -1.3344218236 & -0.9261800368 & 2.2586196763 \\
\hline H51 & -1.0596132074 & -2.3461248894 & 1.6933229954 \\
\hline $\mathrm{O} 40$ & 1.2681699502 & -0.0120692198 & 2.8995763779 \\
\hline H41 & 1.0714276730 & -0.8552042594 & 3.3541151733 \\
\hline $\mathrm{C} 42$ & 2.6497249570 & 0.2931039068 & 3.0505302758 \\
\hline H44 & 3.3006011261 & -0.5490540419 & 2.7521686877 \\
\hline
\end{tabular}




$\begin{array}{llrl}\text { H45 } & 2.8584770041 & 1.1563887713 & 2.4032864710 \\ \text { C45 } & 2.9621817140 & 0.6526152404 & 4.4981412421 \\ \text { F46 } & 2.3087662469 & 1.7584893808 & 4.9111549883 \\ \text { F47 } & 2.6006939517 & -0.3755663893 & 5.3243526856 \\ \text { F48 } & 4.2957376216 & 0.8612557695 & 4.6528832272\end{array}$

\section{TS $_{\text {11-12 }}$ (TFE)}

The total Gibbs free energy, Gtot (Htot - T*S): $\quad-2034.615165$ hartrees Gibbs solvation energy $-18.7541 \mathrm{kcal} / \mathrm{mol}$

This TS could not be located in TFE; the Gibbs energy is calculated using Gsolv corrections to the gas phase energy above.

Other Gibbs solvation energies used for this and similar calculations;

7 ,

11, $\quad-21.6583 \mathrm{kcal} / \mathrm{mol}$

13-TFE, $\quad-23.1329 \mathrm{kcal} / \mathrm{mol}$

TFE, $\quad-4.7999 \mathrm{kcal} / \mathrm{mol}$

$\mathbf{H}_{2} \mathbf{O}, \quad-7.3771 \mathrm{kcal} / \mathrm{mol}$ 
$\mathrm{TS}_{13-11}$ (gas phase)

The total Gibbs free energy, Gtot (Htot - T*S): $\quad-2034.635355$ hartrees

\begin{tabular}{|c|c|c|c|}
\hline $\mathrm{C} 1$ & 1.1007443803 & 1.5422323010 & -3.8200694641 \\
\hline $\mathrm{C} 2$ & -0.1109749160 & 1.6911840158 & -3.1339949336 \\
\hline $\mathrm{H} 3$ & 1.1762742146 & 1.8217620803 & -4.8747461505 \\
\hline $\mathrm{C} 4$ & 2.2015677004 & 1.0170652546 & -3.1460423451 \\
\hline $\mathrm{C} 5$ & -0.1979886056 & 1.3430792651 & -1.7778154562 \\
\hline H6 & -0.9969857199 & 2.0785508231 & -3.6429945670 \\
\hline $\mathrm{C} 7$ & 5.2957364056 & -0.9221567494 & -0.5283446917 \\
\hline $\mathrm{C} 8$ & 2.0908954935 & 0.6753893481 & -1.7880192088 \\
\hline H9 & 3.1524114049 & 0.8610959146 & -3.6601256377 \\
\hline $\mathrm{C} 10$ & 4.4134035675 & -0.2838409462 & -1.4033408437 \\
\hline N11 & 0.8991249867 & 0.8890006053 & -1.1158510559 \\
\hline $\mathrm{C} 12$ & 4.8844906429 & -1.2294305319 & 0.7823352385 \\
\hline $\mathrm{C} 13$ & 3.1156778268 & 0.0500875647 & -0.9644315188 \\
\hline $\mathrm{C} 14$ & 3.5973020847 & -0.8987561589 & 1.2295162876 \\
\hline $\mathrm{C} 15$ & 2.6968271777 & -0.2521134034 & 0.3659027722 \\
\hline H16 & 6.3047864791 & -1.1807976878 & -0.8620587324 \\
\hline H17 & 4.7382666247 & -0.0447404117 & -2.4214735669 \\
\hline H18 & 5.5810128475 & -1.7298717068 & 1.4637181111 \\
\hline H19 & 3.2850380748 & -1.1268736528 & 2.2533514504 \\
\hline Pt20 & 0.9062797417 & 0.3981064102 & 0.8307901131 \\
\hline $\mathrm{O} 21$ & 0.7830064223 & -0.3619408619 & 2.7675923097 \\
\hline $\mathrm{H} 22$ & 0.4336884171 & 0.3946026841 & 3.2826780685 \\
\hline $\mathrm{S} 23$ & -1.5865062744 & 2.3125288474 & 0.5883571650 \\
\hline $\mathrm{O} 24$ & -0.7125098994 & 3.4953936273 & 0.4230132805 \\
\hline $\mathrm{C} 25$ & -1.5480933063 & 1.4567584712 & -1.0866411424 \\
\hline $\mathrm{C} 26$ & -2.4078063302 & 0.2012086171 & -1.0992945029 \\
\hline $\mathrm{C} 27$ & -3.3658999132 & 0.0807182247 & -2.1242942152 \\
\hline $\mathrm{C} 28$ & -4.2369392750 & -1.0084260955 & -2.1807591494 \\
\hline $\mathrm{C} 29$ & -4.1648973074 & -1.9828273514 & -1.1794357470 \\
\hline $\mathrm{C} 30$ & -3.2062621040 & -1.8268079979 & -0.1838636624 \\
\hline N31 & -2.3425069534 & -0.7820902592 & -0.1566787928 \\
\hline $\mathrm{O} 32$ & -1.0130289418 & 1.2235302307 & 1.5276633295 \\
\hline $\mathrm{O} 33$ & -3.0334626711 & 2.5130295658 & 0.8349727968 \\
\hline H34 & -2.1152701245 & 2.1855883727 & -1.6880676263 \\
\hline H35 & -3.4229640569 & 0.8687873242 & -2.8790438920 \\
\hline H36 & -4.9711784593 & -1.0854077104 & -2.9880574223 \\
\hline H37 & -4.8351117421 & -2.8447148483 & -1.1600562348 \\
\hline H38 & -3.0925200631 & -2.5347184863 & 0.6407560093 \\
\hline $\mathrm{H} 45$ & -1.6187988041 & -0.9444962873 & 0.7808440416 \\
\hline $\mathrm{H} 46$ & -0.2382026385 & -0.9890723234 & 2.4097362123 \\
\hline $\mathrm{O} 47$ & -1.0827554633 & -1.6239868507 & 1.8516526262 \\
\hline $\mathrm{C} 48$ & -0.4869727491 & -2.8630917900 & 1.5295355895 \\
\hline H49 & -0.6069335147 & -3.1178073726 & 0.4582942761 \\
\hline
\end{tabular}




$\begin{array}{lrrr}\text { H50 } & 0.5987844579 & -2.8609151074 & 1.7433365269 \\ \text { C51 } & -1.1176457534 & -3.9896452852 & 2.3413661359 \\ \text { F52 } & -1.0114211257 & -3.7845811115 & 3.6716709085 \\ \text { F53 } & -2.4551780547 & -4.1302904566 & 2.0586175891 \\ \text { F54 } & -0.5228961731 & -5.1770859355 & 2.0446970923\end{array}$


$\mathrm{TS}_{13-11}$ (TFE)

The total Gibbs free energy, Gtot (Htot - T*S): $\quad-2034.671334$ hartrees

\begin{tabular}{|c|c|c|c|}
\hline $\mathrm{C} 1$ & 1.0945563949 & 1.5315247600 & -3.8273084343 \\
\hline $\mathrm{C} 2$ & -0.1155234902 & 1.6908332399 & -3.1369202549 \\
\hline $\mathrm{H} 3$ & 1.1714125540 & 1.8107255997 & -4.8834200925 \\
\hline $\mathrm{C} 4$ & 2.1971620454 & 1.0053563939 & -3.1532018981 \\
\hline $\mathrm{C} 5$ & -0.2019940575 & 1.3364390541 & -1.7806827759 \\
\hline H6 & -1.0004566708 & 2.0797334673 & -3.6500372495 \\
\hline $\mathrm{C} 7$ & 5.2999479975 & -0.9389911217 & -0.5318010737 \\
\hline $\mathrm{C} 8$ & 2.0864124576 & 0.6619695048 & -1.7951753541 \\
\hline H9 & 3.1471407842 & 0.8534422878 & -3.6742458537 \\
\hline $\mathrm{C} 10$ & 4.4139423335 & -0.3000563424 & -1.4081493958 \\
\hline N11 & 0.8988347274 & 0.8829261975 & -1.1177293688 \\
\hline $\mathrm{C} 12$ & 4.8901302023 & -1.2482885184 & 0.7788575271 \\
\hline $\mathrm{C} 13$ & 3.1158321982 & 0.0375342838 & -0.9687116446 \\
\hline $\mathrm{C} 14$ & 3.5995046684 & -0.9160849262 & 1.2239175022 \\
\hline $\mathrm{C} 15$ & 2.7014002123 & -0.2585022242 & 0.3654282892 \\
\hline H16 & 6.3108003344 & -1.1947594890 & -0.8655273745 \\
\hline H17 & 4.7400244864 & -0.0641016743 & -2.4279021229 \\
\hline H18 & 5.5854166526 & -1.7476937450 & 1.4639387353 \\
\hline H19 & 3.2932630662 & -1.1521568475 & 2.2478170058 \\
\hline Pt20 & 0.9145031307 & 0.4117240538 & 0.8416342756 \\
\hline $\mathrm{O} 21$ & 0.7675104745 & -0.3422479825 & 2.8055782225 \\
\hline $\mathrm{H} 22$ & 0.4068815552 & 0.3891002544 & 3.3540232579 \\
\hline $\mathrm{S} 23$ & -1.5941395372 & 2.3098496176 & 0.5656383865 \\
\hline $\mathrm{O} 24$ & -0.7366658739 & 3.5194011015 & 0.4164391740 \\
\hline $\mathrm{C} 25$ & -1.5594395557 & 1.4517856606 & -1.0922111407 \\
\hline $\mathrm{C} 26$ & -2.4191137734 & 0.1832339198 & -1.1064128872 \\
\hline $\mathrm{C} 27$ & -3.3739004956 & 0.0723792976 & -2.1343078546 \\
\hline $\mathrm{C} 28$ & -4.2454623242 & -1.0212266811 & -2.1977999723 \\
\hline $\mathrm{C} 29$ & -4.1767978927 & -1.9962803504 & -1.1963694930 \\
\hline $\mathrm{C} 30$ & -3.2157554046 & -1.8434271178 & -0.2000657689 \\
\hline N31 & -2.3431872640 & -0.8043900051 & -0.1656712682 \\
\hline $\mathrm{O} 32$ & -1.0173448103 & 1.2621610470 & 1.5399966835 \\
\hline $\mathrm{O} 33$ & -3.0380543952 & 2.5417274410 & 0.8452921817 \\
\hline H34 & -2.1266161935 & 2.1795435818 & -1.6993982342 \\
\hline H35 & -3.4371256568 & 0.8630019639 & -2.8882018688 \\
\hline H36 & -4.9804347410 & -1.0945648300 & -3.0063758532 \\
\hline H37 & -4.8533511843 & -2.8556496929 & -1.1740452698 \\
\hline H38 & -3.1160124029 & -2.5535364491 & 0.6236091268 \\
\hline $\mathrm{H} 45$ & -1.6015714881 & -0.9964811483 & 0.7916134650 \\
\hline $\mathrm{H} 46$ & -0.1729957935 & -0.9651871309 & 2.4613795577 \\
\hline $\mathrm{O} 47$ & -1.0707316971 & -1.6289833708 & 1.8439228531 \\
\hline $\mathrm{C} 48$ & -0.4896989146 & -2.8743481214 & 1.5132414665 \\
\hline H49 & -0.6145377614 & -3.1254425192 & 0.4417101402 \\
\hline
\end{tabular}




$\begin{array}{lrll}\text { H50 } & 0.5973836027 & -2.8892101279 & 1.7245263668 \\ \text { C51 } & -1.1166729169 & -4.0013510442 & 2.3290516087 \\ \text { F52 } & -1.0062891493 & -3.7861128241 & 3.6634345101 \\ \text { F53 } & -2.4516853032 & -4.1578723204 & 2.0614297689 \\ \text { F54 } & -0.5131972257 & -5.1897150485 & 2.0470413250\end{array}$


$\mathrm{TS}_{13-14}$ (gas phase)

The total Gibbs free energy, Gtot (Htot - T*S): $\quad-2486.880838$ hartrees

\begin{tabular}{|c|c|c|c|}
\hline $\mathrm{C} 1$ & -0.3753330565 & 0.1304695274 & -4.5755386900 \\
\hline $\mathrm{C} 2$ & -1.4858647893 & 0.5884975439 & -3.8520778049 \\
\hline $\mathrm{H} 3$ & -0.4289349277 & 0.0191576078 & -5.6617506309 \\
\hline $\mathrm{C} 4$ & 0.7815721669 & -0.2123522773 & -3.8810097702 \\
\hline $\mathrm{C} 5$ & -1.4047447933 & 0.7446163591 & -2.4649136900 \\
\hline H6 & -2.4312167882 & 0.8101306383 & -4.3532214454 \\
\hline $\mathrm{C} 7$ & 4.1056349223 & -1.4099527587 & -1.1180462844 \\
\hline $\mathrm{C} 8$ & 0.8446057292 & -0.0489506170 & -2.4864678452 \\
\hline H9 & 1.6543109678 & -0.6076773919 & -4.4052852203 \\
\hline $\mathrm{C} 10$ & 3.1254504227 & -1.0691468384 & -2.0501765500 \\
\hline N11 & -0.2333296928 & 0.4955067216 & -1.8015286666 \\
\hline $\mathrm{C} 12$ & 3.9137750694 & -1.0999399115 & 0.2420641706 \\
\hline $\mathrm{C} 13$ & 1.9452746995 & -0.4209869874 & -1.6214833081 \\
\hline C14 & 2.7459091003 & -0.4613259254 & 0.6812079728 \\
\hline $\mathrm{C} 15$ & 1.7500921015 & -0.1155408061 & -0.2431560703 \\
\hline H16 & 5.0223750959 & -1.9086111685 & -1.4456929569 \\
\hline H17 & 3.2746614696 & -1.3059676152 & -3.1086689570 \\
\hline H18 & 4.6905101634 & -1.3368289691 & 0.9759438688 \\
\hline H19 & 2.6410786880 & -0.1860697707 & 1.7340661145 \\
\hline Pt20 & 0.0992407167 & 0.8941760375 & 0.1505365681 \\
\hline $\mathrm{O} 21$ & -0.1464868094 & 0.5563080416 & 2.4127471674 \\
\hline S22 & -2.4923764044 & 2.6459939648 & -0.5695683937 \\
\hline $\mathrm{O} 23$ & -1.7061325934 & 3.6130342582 & -1.3706107205 \\
\hline $\mathrm{C} 24$ & -2.6556716170 & 1.1101710157 & -1.7020181956 \\
\hline $\mathrm{C} 25$ & -3.2799465479 & 0.0187353567 & -0.8878051501 \\
\hline $\mathrm{C} 26$ & -4.6620800271 & -0.2295201628 & -0.8827020933 \\
\hline $\mathrm{C} 27$ & -5.1907904773 & -1.2119239974 & -0.0413774361 \\
\hline $\mathrm{C} 28$ & -4.3415108908 & -1.9476467502 & 0.8024771119 \\
\hline C29 & -2.9803654795 & -1.6639269256 & 0.7778649158 \\
\hline N30 & -2.4978223229 & -0.7180199829 & -0.0537237952 \\
\hline $\mathrm{O} 31$ & -1.7387767108 & 2.0548884507 & 0.6403457742 \\
\hline $\mathrm{O} 32$ & -3.8964553014 & 2.9688739263 & -0.2224221677 \\
\hline H33 & -3.4050785670 & 1.4546668893 & -2.4297352280 \\
\hline H34 & -5.3081063291 & 0.3667938229 & -1.5301501257 \\
\hline H35 & -6.2681656980 & -1.4005811222 & -0.0351290350 \\
\hline H36 & -4.7280870404 & -2.7147060174 & 1.4765668942 \\
\hline H37 & -2.2406475250 & -2.1544615990 & 1.4154119857 \\
\hline H38 & -1.4350081177 & -0.3865210439 & 0.0550484473 \\
\hline H39 & 0.7502882871 & 0.7574060559 & 2.8500400710 \\
\hline $\mathrm{O} 40$ & 2.1246737432 & 1.4921284758 & 3.0871450777 \\
\hline C41 & 3.1314190924 & 1.9017455991 & 3.9615949744 \\
\hline H42 & 3.1627908135 & 3.0017959807 & 4.0843903177 \\
\hline H43 & 2.9832643144 & 1.4564830332 & 4.9633721460 \\
\hline
\end{tabular}




$\begin{array}{lccc}\text { C44 } & 4.5134021749 & 1.4624332558 & 3.4797980382 \\ \text { F45 } & 5.4763937925 & 1.8688955276 & 4.3556283412 \\ \text { F46 } & 4.6074884411 & 0.1019516344 & 3.3780083624 \\ \text { F47 } & 4.8142745822 & 1.9776184281 & 2.2613169987 \\ \text { H48 } & -0.6449204612 & 1.3842613997 & 2.5911954717 \\ \text { H49 } & 1.9276048955 & 2.1478303668 & 2.2170989324 \\ \text { O50 } & 1.3764459087 & 2.6545154798 & 1.1013189715 \\ \text { C51 } & 0.7872518138 & 3.9181414292 & 1.1896467200 \\ \text { H52 } & -0.0385598004 & 4.0422522972 & 0.4648584657 \\ \text { C53 } & 0.2080565178 & 4.2581706716 & 2.5635479269 \\ \text { H54 } & 1.5250417702 & 4.7257857720 & 0.9843751751 \\ \text { F55 } & -0.4114010740 & 5.4668597371 & 2.5376253163 \\ \text { F56 } & -0.7241280710 & 3.3470210457 & 3.0074124578 \\ \text { F57 } & 1.1659687989 & 4.3193328871 & 3.5363857065\end{array}$

\section{TS13-14 (TFE)}

The total Gibbs free energy, Gtot (Htot - T*S): $\quad-2486.880838$ hartrees Gibbs solvation energy $-22.7099 \mathrm{kcal} / \mathrm{mol}$

This TS could not be located in TFE; the Gibbs energy is calculated using Gsolv corrections to the gas phase energy above.

Other Gibbs solvation energies used for this and similar calculations;

7, $\quad-21.0349 \mathrm{kcal} / \mathrm{mol}$

11, $\quad-21.6583 \mathrm{kcal} / \mathrm{mol}$

13-TFE, $\quad-23.1329 \mathrm{kcal} / \mathrm{mol}$

TFE, $\quad-4.7999 \mathrm{kcal} / \mathrm{mol}$

$\mathbf{H}_{2} \mathbf{O}, \quad-7.3771 \mathrm{kcal} / \mathrm{mol}$ 
$\mathrm{TS}_{14-12}$ (gas phase)

The total Gibbs free energy, Gtot (Htot - T*S): $\quad-2410.576726$ hartrees

\begin{tabular}{|c|c|c|c|}
\hline $\mathrm{C} 1$ & 1.1448215226 & 1.6200118455 & -3.8076458272 \\
\hline $\mathrm{C} 2$ & -0.0845752128 & 1.7344181446 & -3.1471241303 \\
\hline $\mathrm{H} 3$ & 1.2408669243 & 1.9251054839 & -4.8536482198 \\
\hline $\mathrm{C} 4$ & 2.2361227926 & 1.0915336034 & -3.1213515398 \\
\hline $\mathrm{C} 5$ & -0.1984808862 & 1.3583048679 & -1.7999378945 \\
\hline H6 & -0.9648632453 & 2.1181800372 & -3.6683872822 \\
\hline $\mathrm{C} 7$ & 5.2607991505 & -0.9704534463 & -0.5330032448 \\
\hline $\mathrm{C} 8$ & 2.0982985137 & 0.7181783361 & -1.7743314400 \\
\hline H9 & 3.1996406872 & 0.9546352963 & -3.6168188787 \\
\hline $\mathrm{C} 10$ & 4.4026567270 & -0.2775326079 & -1.3903555066 \\
\hline N11 & 0.8923464960 & 0.9113364117 & -1.1221961467 \\
\hline $\mathrm{C} 12$ & 4.8252302659 & -1.3270532155 & 0.7570159495 \\
\hline $\mathrm{C} 13$ & 3.1067686569 & 0.0637621687 & -0.9528028572 \\
\hline $\mathrm{C} 14$ & 3.5394802708 & -0.9870586691 & 1.2040270468 \\
\hline $\mathrm{C} 15$ & 2.6659884197 & -0.2797187055 & 0.3601710077 \\
\hline H16 & 6.2680686377 & -1.2360239662 & -0.8669076813 \\
\hline H17 & 4.7429378585 & -0.0061301652 & -2.3953096369 \\
\hline H18 & 5.5008010585 & -1.8755802028 & 1.4221042863 \\
\hline H19 & 3.2067832824 & -1.2614957887 & 2.2105435565 \\
\hline Pt20 & 0.8786464919 & 0.3926133403 & 0.8186398764 \\
\hline $\mathrm{O} 21$ & 0.7565881521 & -0.4654421057 & 2.7139618980 \\
\hline $\mathrm{C} 22$ & 0.6300873335 & 0.4079787449 & 3.8301312624 \\
\hline $\mathrm{S} 23$ & -1.6441693093 & 2.2858805465 & 0.5367404137 \\
\hline $\mathrm{O} 24$ & -0.7986250057 & 3.4911429817 & 0.3811445947 \\
\hline $\mathrm{C} 25$ & -1.5658407559 & 1.4391345394 & -1.1402906642 \\
\hline $\mathrm{C} 26$ & -2.4195167810 & 0.1767664876 & -1.1709001124 \\
\hline $\mathrm{C} 27$ & -3.3693104155 & 0.0629874306 & -2.2049562246 \\
\hline $\mathrm{C} 28$ & -4.2589879018 & -1.0114777809 & -2.2545093542 \\
\hline $\mathrm{C} 29$ & -4.2139844564 & -1.9729461464 & -1.2386993344 \\
\hline $\mathrm{C} 30$ & -3.2526659071 & -1.8237742921 & -0.2435787484 \\
\hline N31 & -2.3663905642 & -0.7987396661 & -0.2213394882 \\
\hline $\mathrm{O} 32$ & -1.0499000462 & 1.2127814812 & 1.4817875087 \\
\hline $\mathrm{O} 33$ & -3.0966407065 & 2.4497888920 & 0.7745441666 \\
\hline H34 & -2.1291317441 & 2.1667225234 & -1.7471755032 \\
\hline H35 & -3.4091751535 & 0.8450203342 & -2.9675428450 \\
\hline H36 & -4.9902124491 & -1.0842490695 & -3.0648698707 \\
\hline H37 & -4.9069215080 & -2.8165162721 & -1.2081646848 \\
\hline H38 & -3.1635535064 & -2.5221600349 & 0.5939420081 \\
\hline C39 & 0.3264360138 & -0.4143296361 & 5.0776742633 \\
\hline $\mathrm{H} 40$ & 1.5808316962 & 0.9427407956 & 3.9998965208 \\
\hline H41 & -0.1776866590 & 1.1484773118 & 3.6928430442 \\
\hline $\mathrm{F} 42$ & 0.2940024020 & 0.3991902768 & 6.1681720027 \\
\hline F43 & -0.8791729756 & -1.0368011086 & 4.9883764593 \\
\hline
\end{tabular}




$\begin{array}{llll}\text { F44 } & 1.2632836909 & -1.3719313530 & 5.2994829573 \\ \text { H45 } & -1.6143244251 & -1.0156304971 & 0.7705149568 \\ \text { H46 } & -0.3248034646 & -1.0420972556 & 2.3592480735 \\ \text { O47 } & -1.1433873617 & -1.6422630890 & 1.7780768402 \\ \text { C48 } & -0.5330373353 & -2.8894225167 & 1.4714742993 \\ \text { H49 } & -0.8481839140 & -3.2542494197 & 0.4776481781 \\ \text { H50 } & 0.5691159417 & -2.8114401525 & 1.4690349901 \\ \text { C51 } & -0.9497684418 & -3.9264187078 & 2.5077716464 \\ \text { F52 } & -0.6083253929 & -3.5546140488 & 3.7602125793 \\ \text { F53 } & -2.3014197025 & -4.1265178930 & 2.4861980128 \\ \text { F54 } & -0.3533937961 & -5.1202794286 & 2.2403229016\end{array}$


$\mathrm{TS}_{14-12}$ (TFE)

The total Gibbs free energy, Gtot $($ Htot $-\mathrm{T} * \mathrm{~S}): \quad-2410.606062$ hartrees

\begin{tabular}{|c|c|c|c|}
\hline $\mathrm{C} 1$ & 1.1440790929 & 1.6198970948 & -3.8122974481 \\
\hline $\mathrm{C} 2$ & -0.0869968391 & 1.7376287879 & -3.1506616037 \\
\hline $\mathrm{H} 3$ & 1.2406972391 & 1.9264576814 & -4.8589593395 \\
\hline $\mathrm{C} 4$ & 2.2388925471 & 1.0911409593 & -3.1265021475 \\
\hline $\mathrm{C} 5$ & -0.1984086282 & 1.3637334123 & -1.8014923216 \\
\hline H6 & -0.9688904310 & 2.1213569473 & -3.6727639477 \\
\hline $\mathrm{C} 7$ & 5.2677494327 & -0.9742185351 & -0.5282462582 \\
\hline $\mathrm{C} 8$ & 2.1000065593 & 0.7185680610 & -1.7790498208 \\
\hline H9 & 3.2029620269 & 0.9578935657 & -3.6258229402 \\
\hline $\mathrm{C} 10$ & 4.4091005503 & -0.2793680498 & -1.3895629400 \\
\hline N11 & 0.8948700496 & 0.9129003856 & -1.1251603136 \\
\hline $\mathrm{C} 12$ & 4.8337158984 & -1.3319878762 & 0.7630946113 \\
\hline $\mathrm{C} 13$ & 3.1119585421 & 0.0629698915 & -0.9537503751 \\
\hline $\mathrm{C} 14$ & 3.5451186525 & -0.9888157949 & 1.2070610715 \\
\hline $\mathrm{C} 15$ & 2.6737080720 & -0.2810689278 & 0.3601399385 \\
\hline H16 & 6.2753758961 & -1.2408990354 & -0.8624610949 \\
\hline H17 & 4.7475181162 & -0.0072997384 & -2.3960138825 \\
\hline H18 & 5.5065792112 & -1.8824238441 & 1.4322646788 \\
\hline H19 & 3.2092897994 & -1.2649489299 & 2.2122471038 \\
\hline Pt20 & 0.8850745079 & 0.3917361461 & 0.8195421078 \\
\hline $\mathrm{O} 21$ & 0.7597740050 & -0.4719869319 & 2.7230364727 \\
\hline $\mathrm{C} 22$ & 0.6318711337 & 0.4085766769 & 3.8352658886 \\
\hline $\mathrm{S} 23$ & -1.6459076155 & 2.2799785409 & 0.5285042007 \\
\hline $\mathrm{O} 24$ & -0.8140163816 & 3.5106013713 & 0.4003148763 \\
\hline $\mathrm{C} 25$ & -1.5726258247 & 1.4449911238 & -1.1417266593 \\
\hline $\mathrm{C} 26$ & -2.4259390266 & 0.1697963503 & -1.1756383591 \\
\hline $\mathrm{C} 27$ & -3.3711368518 & 0.0619719692 & -2.2125996493 \\
\hline $\mathrm{C} 28$ & -4.2624155569 & -1.0167406846 & -2.2605247345 \\
\hline C29 & -4.2186770629 & -1.9773761904 & -1.2427479369 \\
\hline $\mathrm{C} 30$ & -3.2574637044 & -1.8283314279 & -0.2458974062 \\
\hline N31 & -2.3693143297 & -0.8038951611 & -0.2212069435 \\
\hline $\mathrm{O} 32$ & -1.0543694785 & 1.2334822219 & 1.4941510095 \\
\hline $\mathrm{O} 33$ & -3.0977572800 & 2.4820834969 & 0.7900285105 \\
\hline H34 & -2.1348721494 & 2.1765026231 & -1.7497173864 \\
\hline H35 & -3.4156564082 & 0.8492962730 & -2.9720033552 \\
\hline H36 & -4.9965261104 & -1.0863768386 & -3.0693578661 \\
\hline H37 & -4.9107050162 & -2.8232721646 & -1.2063695845 \\
\hline H38 & -3.1759204284 & -2.5295227099 & 0.5906756761 \\
\hline C39 & 0.3261817870 & -0.4118210355 & 5.0815028752 \\
\hline $\mathrm{H} 40$ & 1.5824203262 & 0.9455661608 & 3.9992341517 \\
\hline $\mathrm{H} 41$ & -0.1769608125 & 1.1492770465 & 3.7022838578 \\
\hline $\mathrm{F} 42$ & 0.2906451184 & 0.3967612135 & 6.1762882465 \\
\hline F43 & -0.8806127386 & -1.0363911368 & 4.9930759727 \\
\hline
\end{tabular}




$\begin{array}{lccc}\text { F44 } & 1.2615761052 & -1.3721177586 & 5.3031049432 \\ \text { H45 } & -1.6052376742 & -1.0417486564 & 0.7912465674 \\ \text { H46 } & -0.3073944915 & -1.0333588736 & 2.3757540409 \\ \text { O47 } & -1.1423092105 & -1.6437611245 & 1.7900579216 \\ \text { C48 } & -0.5324796311 & -2.8916089178 & 1.4696107003 \\ \text { H49 } & -0.8450767134 & -3.2461997926 & 0.4715417619 \\ \text { H50 } & 0.5699304614 & -2.8146195365 & 1.4709632519 \\ \text { C51 } & -0.9502176627 & -3.9284078114 & 2.5038526316 \\ \text { F52 } & -0.6067785421 & -3.5539037108 & 3.7608154286 \\ \text { F53 } & -2.2999267957 & -4.1298289258 & 2.4929556880 \\ \text { F54 } & -0.3529140577 & -5.1239806762 & 2.2457872938\end{array}$




\section{$\mathrm{C}_{6} \mathrm{H}_{6}$ (TFE)}

The total Gibbs free energy, Gtot (Htot - T*S): $\quad-231.869772$ hartrees

$\begin{array}{lccc}\text { C1 } & 1.4028355169 & 0.0000000000 & 0.0000000000 \\ \text { C2 } & 0.7014177585 & 1.2148911950 & 0.0000000000 \\ \text { C3 } & -0.7014177585 & 1.2148911950 & 0.0000000000 \\ \text { C4 } & -1.4028355169 & 0.0000000000 & 0.0000000000 \\ \text { C5 } & -0.7014177585 & -1.2148911950 & 0.0000000000 \\ \text { C6 } & 0.7014177585 & -1.2148911950 & 0.0000000000 \\ \text { H7 } & 2.4973940632 & 0.0000000000 & 0.0000000000 \\ \text { H8 } & 1.2486970316 & 2.1628067020 & 0.0000000000 \\ \text { H9 } & -1.2486970316 & 2.1628067020 & 0.0000000000 \\ \text { H10 } & -2.4973940632 & 0.0000000000 & 0.0000000000 \\ \text { H11 } & -1.2486970316 & -2.1628067020 & 0.0000000000 \\ \text { H12 } & 1.2486970316 & -2.1628067020 & 0.0000000000\end{array}$

\section{$\mathrm{C}_{6} \mathrm{D}_{6}$ (TFE)}

The total Gibbs free energy, Gtot $($ Htot $-\mathrm{T} * \mathrm{~S})$ : $\quad-231.889613$ hartrees

$\begin{array}{lccc}\text { C1 } & 1.4046554294 & 0.0000000000 & 0.0000000000 \\ \text { C2 } & 0.7023277147 & 1.2164672854 & 0.0000000000 \\ \text { C3 } & -0.7023277147 & 1.2164672854 & 0.0000000000 \\ \text { C4 } & -1.4046554294 & 0.0000000000 & 0.0000000000 \\ \text { C5 } & -0.7023277147 & -1.2164672854 & 0.0000000000 \\ \text { C6 } & 0.7023277147 & -1.2164672854 & 0.0000000000 \\ \text { H7 } & 2.5001351668 & 0.0000000000 & 0.0000000000 \\ \text { H8 } & 1.2500675834 & 2.1651805674 & 0.0000000000 \\ \text { H9 } & -1.2500675834 & 2.1651805674 & 0.0000000000 \\ \text { H10 } & -2.5001351668 & 0.0000000000 & 0.0000000000 \\ \text { H11 } & -1.2500675834 & -2.1651805674 & 0.0000000000 \\ \text { H12 } & 1.2500675834 & -2.1651805674 & 0.0000000000\end{array}$




\section{Complex 22 (TFE)}

The total Gibbs free energy, Gtot (Htot - T*S): $\quad-1737.907389$ hartrees

\begin{tabular}{|c|c|c|c|}
\hline $\mathrm{C} 1$ & 1.8824269926 & 1.2854272802 & -3.7899398347 \\
\hline $\mathrm{C} 2$ & 0.6343929500 & 1.6797444686 & -3.2972466005 \\
\hline $\mathrm{H} 3$ & 2.3055653307 & 1.7650384011 & -4.6790343197 \\
\hline $\mathrm{C} 4$ & 2.5702154992 & 0.2651587319 & -3.1359579548 \\
\hline $\mathrm{C} 5$ & 0.0919273932 & 1.0555433367 & -2.1633493877 \\
\hline H6 & 0.0576869043 & 2.4637341054 & -3.7973894464 \\
\hline $\mathrm{C} 7$ & 4.4254881710 & -3.0447529832 & -0.8569856819 \\
\hline $\mathrm{C} 8$ & 2.0169853749 & -0.3311786907 & -1.9895467220 \\
\hline H9 & 3.5447325240 & -0.0641376752 & -3.5039576268 \\
\hline $\mathrm{C} 10$ & 3.8784832013 & -2.0040736265 & -1.6155578248 \\
\hline N11 & 0.7923906841 & 0.0841077563 & -1.5043690976 \\
\hline C12 & 3.7441151886 & -3.4998358154 & 0.2832627038 \\
\hline C13 & 2.6534619103 & -1.4124046020 & -1.2342966219 \\
\hline C14 & 2.5259321000 & -2.9160920104 & 0.6680377651 \\
\hline C15 & 1.9554471820 & -1.8604104169 & -0.0714958403 \\
\hline H16 & 5.3766354145 & -3.5004298429 & -1.1527775779 \\
\hline $\mathrm{H} 17$ & 4.4168304265 & -1.6598745489 & -2.5064318894 \\
\hline $\mathrm{H} 18$ & 4.1637078048 & -4.3141019009 & 0.8857504963 \\
\hline H19 & 2.0407493598 & -3.3067352353 & 1.5670765539 \\
\hline $\mathrm{Pt} 20$ & 0.2800704762 & -0.8427377771 & 0.3020503910 \\
\hline $\mathrm{S} 21$ & -1.5212135773 & 1.7517642471 & 0.0578408218 \\
\hline $\mathrm{O} 22$ & -0.3367019774 & 2.5585680352 & 0.4862583013 \\
\hline $\mathrm{C} 23$ & -1.3129181768 & 1.4601392882 & -1.7709831588 \\
\hline $\mathrm{C} 24$ & -2.3800300675 & 0.5149378050 & -2.3241488783 \\
\hline $\mathrm{C} 25$ & -3.7201269602 & 0.9397397704 & -2.4302252877 \\
\hline $\mathrm{C} 26$ & -4.6633105539 & 0.0554678380 & -2.9690497702 \\
\hline $\mathrm{C} 27$ & -4.2388219142 & -1.2104163005 & -3.3990364669 \\
\hline $\mathrm{C} 28$ & -2.8836660879 & -1.5368008917 & -3.2567118394 \\
\hline N29 & -1.9661879219 & -0.7021998047 & -2.7294203576 \\
\hline $\mathrm{O} 30$ & -1.5534225452 & 0.3246717414 & 0.6335536512 \\
\hline O31 & -2.8479312021 & 2.4116696572 & 0.2241158916 \\
\hline H32 & -1.4929118608 & 2.4669142540 & -2.1885578804 \\
\hline H33 & -4.0137889653 & 1.9373637959 & -2.0906526647 \\
\hline H34 & -5.7142846814 & 0.3526407170 & -3.0604326417 \\
\hline H35 & -4.9375128475 & -1.9302301659 & -3.8367690599 \\
\hline H36 & -2.5077655558 & -2.5129184623 & -3.5924718861 \\
\hline C37 & -0.4449032652 & -2.3341531613 & 1.9046981324 \\
\hline C38 & 0.3943541052 & -1.3429061817 & 2.5260808600 \\
\hline H39 & -0.0144929534 & -3.2573443771 & 1.5057817382 \\
\hline $\mathrm{C} 40$ & -1.8578766720 & -2.2973994043 & 2.1355998886 \\
\hline $\mathrm{C} 41$ & -0.2067191759 & -0.3352212069 & 3.3486094006 \\
\hline $\mathrm{H} 42$ & 1.4722132380 & -1.5061460627 & 2.6166892498 \\
\hline $\mathrm{C} 43$ & -2.4073625393 & -1.3080553529 & 2.9350965987 \\
\hline
\end{tabular}




$\begin{array}{lrrr}\text { H44 } & -2.4904390606 & -3.0763674421 & 1.6972416795 \\ \text { H45 } & 0.4344767801 & 0.4064336251 & 3.8359127976 \\ \text { C46 } & -1.5786402537 & -0.3206931887 & 3.5404995186 \\ \text { H47 } & -2.0349511745 & 0.4489354756 & 4.1729830340 \\ \text { H48 } & -3.4880264809 & -1.2872389406 & 3.1162846345\end{array}$




\section{Complex 23 (TFE)}

The total Gibbs free energy, Gtot (Htot - T*S): $\quad-1737.896693$ hartrees

\begin{tabular}{|c|c|c|c|}
\hline $\mathrm{C} 1$ & 0.4282390000 & 0.2873810000 & -3.5157160000 \\
\hline $\mathrm{C} 2$ & -0.7822770000 & 0.7318480000 & -2.9716670000 \\
\hline $\mathrm{H} 3$ & 0.6769350000 & 0.4853770000 & -4.5641820000 \\
\hline $\mathrm{C} 4$ & 1.3058280000 & -0.4247640000 & -2.6995680000 \\
\hline $\mathrm{C} 5$ & -1.0865930000 & 0.4896610000 & -1.6232150000 \\
\hline H6 & -1.5162940000 & 1.2646030000 & -3.5830770000 \\
\hline $\mathrm{C} 7$ & 3.6493380000 & -2.8824160000 & 0.1809800000 \\
\hline $\mathrm{C} 8$ & 0.9882130000 & -0.6420660000 & -1.3486130000 \\
\hline H9 & 2.2478190000 & -0.8117640000 & -3.0963310000 \\
\hline $\mathrm{C} 10$ & 2.9737610000 & -2.1075020000 & -0.7681430000 \\
\hline N11 & -0.1871280000 & -0.1468600000 & -0.8170830000 \\
\hline C12 & 3.1412060000 & -2.9770640000 & 1.4872130000 \\
\hline C13 & 1.8028790000 & -1.4082310000 & -0.4078060000 \\
\hline C14 & 1.9771700000 & -2.2810610000 & 1.8545520000 \\
\hline C15 & 1.3019670000 & -1.4650000000 & 0.9254190000 \\
\hline H16 & 4.5606560000 & -3.4200130000 & -0.1000900000 \\
\hline H17 & 3.3560300000 & -2.0608300000 & -1.7932580000 \\
\hline H18 & 3.6543990000 & -3.5984820000 & 2.2295820000 \\
\hline H19 & 1.6113350000 & -2.3915080000 & 2.8804680000 \\
\hline $\mathrm{Pt} 20$ & -0.2975230000 & -0.3258280000 & 1.2264450000 \\
\hline S21 & -2.3961600000 & 1.9365650000 & 0.4116390000 \\
\hline $\mathrm{O} 22$ & -1.3119540000 & 2.9349570000 & 0.1604890000 \\
\hline $\mathrm{C} 23$ & -2.4579050000 & 0.8920950000 & -1.1310710000 \\
\hline $\mathrm{C} 24$ & -3.4277350000 & -0.2842130000 & -1.0177520000 \\
\hline $\mathrm{C} 25$ & -4.8131820000 & -0.0540330000 & -0.9046040000 \\
\hline $\mathrm{C} 26$ & -5.6714560000 & -1.1580560000 & -0.8255990000 \\
\hline $\mathrm{C} 27$ & -5.1261200000 & -2.4492120000 & -0.8772420000 \\
\hline $\mathrm{C} 28$ & -3.7367370000 & -2.5724520000 & -1.0109040000 \\
\hline N29 & -2.8959130000 & -1.5214160000 & -1.0795080000 \\
\hline $\mathrm{O} 30$ & -2.0757380000 & 0.9293560000 & 1.5368600000 \\
\hline $\mathrm{O} 31$ & -3.7651060000 & 2.4985150000 & 0.5995830000 \\
\hline H32 & -2.8661070000 & 1.6148300000 & -1.8599410000 \\
\hline H33 & -5.2043880000 & 0.9666880000 & -0.8758440000 \\
\hline H34 & -6.7540100000 & -1.0129970000 & -0.7355420000 \\
\hline H35 & -5.7595650000 & -3.3409490000 & -0.8313230000 \\
\hline H36 & -3.2707410000 & -3.5643570000 & -1.0789980000 \\
\hline C37 & -0.1662830000 & -0.1889760000 & 3.5171880000 \\
\hline C38 & 1.1262200000 & 0.3114590000 & 3.8256290000 \\
\hline H39 & -0.2930320000 & -1.2147230000 & 3.0421640000 \\
\hline $\mathrm{C} 40$ & -1.3036700000 & 0.3275740000 & 4.1888180000 \\
\hline $\mathrm{C} 41$ & 1.2650200000 & 1.3567520000 & 4.7474620000 \\
\hline H42 & 2.0086610000 & -0.1128020000 & 3.3394300000 \\
\hline $\mathrm{C} 43$ & -1.1508810000 & 1.3609970000 & 5.1167520000 \\
\hline
\end{tabular}




$\begin{array}{lrrr}\text { H44 } & -2.2940710000 & -0.0826880000 & 3.9742120000 \\ \text { H45 } & 2.2569890000 & 1.7621140000 & 4.9723600000 \\ \text { C46 } & 0.1285940000 & 1.8835740000 & 5.3840650000 \\ \text { H47 } & 0.2402980000 & 2.7055360000 & 6.1010860000 \\ \text { H48 } & -2.0267210000 & 1.7689400000 & 5.6315390000\end{array}$




\section{Complex 24 (TFE)}

The total Gibbs free energy, Gtot (Htot - T*S): $\quad-1737.914594$ hartrees

$\begin{array}{lccc}\text { C1 } & 0.4589188166 & 0.1725432925 & -3.9127190082 \\ \text { C2 } & -0.7719290645 & 0.6660618756 & -3.4435707194 \\ \text { H3 } & 0.6948190523 & 0.2135437359 & -4.9819760706 \\ \text { C4 } & 1.3613219056 & -0.4260429545 & -3.0254620784 \\ \text { C5 } & -1.0239835675 & 0.6206624921 & -2.0643851758 \\ \text { H6 } & -1.5270676529 & 1.0603095721 & -4.1309137022 \\ \text { C7 } & 3.3649754537 & -2.8667895769 & 0.1636960696 \\ \text { C8 } & 1.0501673999 & -0.4609817154 & -1.6517084707 \\ \text { H9 } & 2.2837810671 & -0.8813535423 & -3.3971563283 \\ \text { C10 } & 2.8579993000 & -2.0384486094 & -0.8440813892 \\ \text { N11 } & -0.0866792553 & 0.1497397286 & -1.2176241991 \\ \text { C12 } & 2.7479738109 & -2.8862444362 & 1.4255611665 \\ \text { C13 } & 1.7415167942 & -1.2119279292 & -0.5927609866 \\ \text { C14 } & 1.6468854674 & -2.0541234445 & 1.6979782118 \\ \text { C15 } & 1.1418303089 & -1.1982961885 & 0.7071603762 \\ \text { H16 } & 4.2302907457 & -3.5071117988 & -0.0386634664 \\ \text { H17 } & 3.3209458468 & -2.0488508701 & -1.8379196788 \\ \text { H18 } & 3.1263401630 & -3.5497564295 & 2.2126098598 \\ \text { H19 } & 1.1917507439 & -2.0744396309 & 2.6912029267 \\ \text { P120 } & -0.3339327485 & 0.1665535926 & 0.9194882340 \\ \text { S21 } & -2.2631107997 & 2.4608611958 & -0.3016909482 \\ \text { O22 } & -1.2619188704 & 3.3752957120 & -0.9230516553 \\ \text { C23 } & -2.3614524319 & 0.9547537419 & -1.4416947200 \\ \text { C24 } & -2.9689097331 & -0.2417788425 & -0.7164056789 \\ \text { C25 } & -4.2469681345 & -0.7095309550 & -1.0653915619 \\ \text { C26 } & -4.7771151156 & -1.8290257407 & -0.4092998060 \\ \text { C27 } & -4.0136516193 & -2.4654643040 & 0.5785374940 \\ \text { C28 } & -2.7544719353 & -1.9424535166 & 0.8891187168 \\ \text { N29 } & -2.2499808089 & -0.8551112935 & 0.2657977397 \\ \text { O30 } & -1.7963436521 & 1.8843057661 & 1.0582893958 \\ \text { O31 } & -3.6606917276 & 2.9705809570 & -0.1932654659 \\ \text { H32 } & -3.0556204367 & 1.2883328287 & -2.2304182722 \\ \text { H33 } & -4.8153514048 & -0.1950642561 & -1.8471178807 \\ \text { H34 } & -5.7738868758 & -2.2006549208 & -0.6699478569 \\ \text { H35 } & -4.3826996509 & -3.3454885846 & 1.1141427379 \\ \text { H36 } & -2.1242139630 & -2.3860350201 & 1.6666244937 \\ \text { C37 } & -0.5674365899 & 0.0940508499 & 2.9485358605 \\ \text { C38 } & 0.5102576419 & 0.0975232093 & 3.8612895168 \\ \text { H39 } & 0.8875605991 & 1.0506526518 & 1.2835866950 \\ & -1.8801698973 & 0.0845721159 & 3.4685467468 \\ \text { C40 } & 0.2820941058 & 0.0471909880 & 5.2464690043 \\ \text { H3 } & 1.5415626694 & 0.1403034769 & 3.4938509820 \\ \text { H1 } 2.1077755689 & 0.0316731486 & 4.8538801185\end{array}$




$\begin{array}{lrcc}\text { H44 } & -2.7373419520 & 0.1412197206 & 2.7911146957 \\ \text { H45 } & 1.1362209167 & 0.0491871537 & 5.9339128099 \\ \text { C46 } & -1.0277767900 & 0.0030625773 & 5.7480474614 \\ \text { H47 } & -1.2051726712 & -0.0430600689 & 6.8279089868 \\ \text { H48 } & -3.1381762349 & 0.0159481981 & 5.2284429523\end{array}$




\section{Complex 25 (TFE)}

The total Gibbs free energy, Gtot (Htot - T*S): $\quad-1737.920973$ hartrees

\begin{tabular}{lccc} 
C1 & 1.2918327012 & 0.7714372111 & -4.3987773161 \\
C2 & 0.0431677983 & 1.2621463004 & -3.9842027150 \\
H3 & 1.6127760101 & 0.8816735965 & -5.4406897091 \\
C4 & 2.1124739252 & 0.1133837505 & -3.4801104810 \\
C5 & -0.3258217078 & 1.1219214323 & -2.6374823250 \\
H6 & -0.6382200242 & 1.7388968780 & -4.6956330112 \\
C7 & 4.1359535074 & -2.2941618359 & -0.3252657714 \\
C8 & 1.6997124162 & -0.0067240313 & -2.1379352497 \\
H9 & 3.0731309947 & -0.3002385200 & -3.7995950386 \\
C10 & 3.5562082929 & -1.5267213479 & -1.3411561164 \\
N11 & 0.5111366444 & 0.5495175597 & -1.7369948297 \\
C12 & 3.5628686182 & -2.2880212881 & 0.9580339211 \\
C13 & 2.4125527985 & -0.7388612819 & -1.0800788400 \\
C14 & 2.4330622860 & -1.5008943953 & 1.2328397876 \\
C15 & 1.8441229777 & -0.6943460911 & 0.2364336376 \\
H16 & 5.0222826593 & -2.9025342599 & -0.5343525198 \\
H17 & 3.9924994792 & -1.5571156820 & -2.3455025324 \\
H18 & 3.9993155029 & -2.9013664653 & 1.7551002606 \\
H19 & 2.0102193591 & -1.5078836787 & 2.2402724937 \\
Pt20 & 0.3154518290 & 0.5513742253 & 0.4258922184 \\
S21 & -1.6999271955 & 2.8152889217 & -0.7578830640 \\
O22 & -0.6117473703 & 3.7767095475 & -1.0892794708 \\
C23 & -1.7103077655 & 1.5452580229 & -2.1798671007 \\
C24 & -2.6494291194 & 0.4140346435 & -1.8246481615 \\
C25 & -3.9581183312 & 0.3218616086 & -2.3227841504 \\
C26 & -4.7954536290 & -0.7279861306 & -1.9138714505 \\
C27 & -4.3259170308 & -1.7007862969 & -1.0147186142 \\
C28 & -3.0224969390 & -1.5791305855 & -0.5412701642 \\
N29 & -2.2432984683 & -0.5505378523 & -0.9503901108 \\
O30 & -1.4349545486 & 1.9681328953 & 0.4985779817 \\
O31 & -3.0882244903 & 3.3557911080 & -0.7396676717 \\
H32 & -2.1791670054 & 2.1227640273 & -2.9931619860 \\
H33 & -4.3171913022 & 1.0788094277 & -3.0261217261 \\
H34 & -5.8204214120 & -0.7856281582 & -2.2956986557 \\
H35 & -4.9542472953 & -2.5299855421 & -0.6761679763 \\
H36 & -2.5670895335 & -2.2732883947 & 0.1715125346 \\
C37 & 0.2336357460 & 0.5810547710 & 2.4327908100 \\
C38 & 1.3711517115 & 0.8468573854 & 3.2314517580 \\
C49 & -1.0061270900 & 0.4323654498 & 3.1007570416 \\
& 1.2770993284 & 0.9617197617 & 4.6280777725 \\
H41 & 2.3493257525 & 0.9657102286 & 2.7539799990 \\
\hline & -1.1020242897 & 0.5320136170 & 4.4984087055 \\
H3 3160498600 & 0.2476194755 & 2.5196409957
\end{tabular}




$\begin{array}{lccc}\text { H44 } & 2.1769379936 & 1.1801731727 & 5.2151563750 \\ \text { C45 } & 0.0398035283 & 0.7994857786 & 5.2703515586 \\ \text { H46 } & -0.0346624417 & 0.8842457859 & 6.3603397963 \\ \text { H47 } & -2.0768830676 & 0.4080951579 & 4.9851366211 \\ \text { H48 } & -1.2832347969 & -0.4239296685 & -0.4722542994\end{array}$




\section{Complex 26 (TFE)}

The total Gibbs free energy, Gtot (Htot - T*S): $\quad-1737.907271$ hartrees

$\begin{array}{lccc}\text { C1 } & 0.0896502007 & -0.5676699105 & -3.8039245699 \\ \text { C2 } & -0.7557756352 & 0.3562092424 & -3.1795346501 \\ \text { H3 } & 0.0146536950 & -0.7413226817 & -4.8823849470 \\ \text { C4 } & 1.0541879008 & -1.2386472516 & -3.0458893401 \\ \text { C5 } & -0.6743377033 & 0.5586544063 & -1.7909251996 \\ \text { H6 } & -1.4870076558 & 0.9308911710 & -3.7546400293 \\ \text { C7 } & 4.2088327178 & -2.7114902228 & -0.2272953555 \\ \text { C8 } & 1.1308628310 & -1.0093635461 & -1.6635023323 \\ \text { H9 } & 1.7668959615 & -1.9174362017 & -3.5217982779 \\ \text { C10 } & 3.1998592295 & -2.3792001752 & -1.1383979573 \\ \text { N11 } & 0.2174567476 & -0.1658879562 & -1.0614483387 \\ \text { C12 } & 4.1850519067 & -2.1667158675 & 1.0674445212 \\ \text { C13 } & 2.1618302629 & -1.5053906911 & -0.7528303671 \\ \text { C14 } & 3.1429346627 & -1.3109283926 & 1.4654971803 \\ \text { C15 } & 2.1052517203 & -0.9740637809 & 0.5754775161 \\ \text { H16 } & 5.0183188534 & -3.3841904776 & -0.5275237950 \\ \text { H17 } & 3.2296470682 & -2.7989122213 & -2.1507784543 \\ \text { H18 } & 4.9856274652 & -2.4055208378 & 1.7768155206 \\ \text { H19 } & 3.1636480379 & -0.9039921287 & 2.4818563929 \\ \text { P120 } & 0.4108314205 & 0.0361392066 & 0.9367025632 \\ \text { H21 } & 1.5596499958 & 0.7040614634 & 2.4392566394 \\ \text { S22 } & -0.6135492338 & 3.2715000507 & -0.8527072284 \\ \text { O23 } & 0.0900105514 & 3.4897766133 & -2.1604288148 \\ \text { C24 } & -1.5440470699 & 1.6028238542 & -1.1476188340 \\ \text { C25 } & -2.3351588984 & 1.1875350780 & 0.0562565419 \\ \text { C26 } & -3.7252879611 & 1.4079524414 & 0.0908367477 \\ \text { C27 } & -4.4709201042 & 0.9940932131 & 1.1983023929 \\ \text { C28 } & -3.8080856861 & 0.3510734963 & 2.2535679375 \\ \text { C29 } & -2.4280449011 & 0.1688555229 & 2.1604782178 \\ \text { N30 } & -1.6976843214 & 0.5914809333 & 1.0977325806 \\ \text { O31 } & 0.3067391632 & 3.0796125868 & 0.3239093755 \\ \text { O32 } & -1.7576708437 & 4.2078436023 & -0.5867939554 \\ \text { H33 } & -2.2604226902 & 1.9320229848 & -1.9139100778 \\ \text { H34 } & -4.2104381465 & 1.8909512549 & -0.7619996976 \\ \text { H35 } & -5.5537779331 & 1.1570120353 & 1.2332499212 \\ \text { H36 } & -4.3469247162 & -0.0077098937 & 3.1358891026 \\ \text { H37 } & -1.8681838058 & -0.3401027711 & 2.9481145832 \\ \text { C38 } & 0.7267409535 & 0.5597127146 & 3.1930269305 \\ \text { C49 } & 0.7014620550 & -0.5984017929 & 4.0098867673 \\ \text { H41 } & 0.0456108026 & 1.7372318885 & 3.5962462139 \\ & 0.0851885228 & 2.6214857734 & 2.9523394330 \\ \text { H4 } & -0.6672748373 & 1.7449730698 & 4.7981525801 \\ \text { H3 } & 1.2590189924 & -1.4918750641 & 3.7118396444\end{array}$




$\begin{array}{llrl}\text { C44 } & -0.0302757875 & -0.5841290913 & 5.2066243788 \\ \text { H45 } & -1.1994617576 & 2.6483417221 & 5.1147802922 \\ \text { C46 } & -0.7034918133 & 0.5862496918 & 5.5989513285 \\ \text { H47 } & -1.2592622919 & 0.5988394606 & 6.5434885993 \\ \text { H48 } & -0.0688086971 & -1.4763519175 & 5.8400057034\end{array}$




\section{Complex 27 (TFE)}

The total Gibbs free energy, Gtot (Htot - T*S): $\quad-1737.919109$ hartrees

\begin{tabular}{|c|c|c|c|}
\hline $\mathrm{C} 1$ & 0.1384026995 & -0.5398916105 & -3.9070176443 \\
\hline $\mathrm{C} 2$ & -0.8157426177 & 0.3185341026 & -3.3331754163 \\
\hline $\mathrm{H} 3$ & 0.1533542585 & -0.6956332173 & -4.9916801853 \\
\hline $\mathrm{C} 4$ & 1.1109059520 & -1.1485749568 & -3.1053213705 \\
\hline $\mathrm{C} 5$ & -0.8196502572 & 0.4780503825 & -1.9390540659 \\
\hline H6 & -1.5279987849 & 0.8686211487 & -3.9554892690 \\
\hline $\mathrm{C} 7$ & 4.3146884646 & -2.1797502114 & -0.1338287508 \\
\hline $\mathrm{C} 8$ & 1.0810416159 & -0.9385704678 & -1.7117725017 \\
\hline H9 & 1.9026397340 & -1.7501570936 & -3.5611995019 \\
\hline $\mathrm{C} 10$ & 3.3002538799 & -1.9871302614 & -1.0791807261 \\
\hline N11 & 0.0602290089 & -0.2088328081 & -1.1797075581 \\
\hline C12 & 4.1543925859 & -1.6878718769 & 1.1715661408 \\
\hline C13 & 2.1149215906 & -1.3060139208 & -0.7269544946 \\
\hline C14 & 2.9699638142 & -1.0264565725 & 1.5437367323 \\
\hline $\mathrm{C} 15$ & 1.9400168100 & -0.8290724401 & 0.6121522884 \\
\hline H16 & 5.2329557970 & -2.7049344002 & -0.4176527706 \\
\hline H17 & 3.4424120341 & -2.3558798413 & -2.1004661392 \\
\hline H18 & 4.9538678603 & -1.8235171233 & 1.9094137929 \\
\hline H19 & 2.8536214653 & -0.6632811270 & 2.5684522011 \\
\hline Pt20 & 0.1106543570 & -0.0218114111 & 0.9488672751 \\
\hline $\mathrm{H} 21$ & -0.2145114465 & -1.4830064423 & 1.3158072718 \\
\hline S22 & -0.4950885877 & 2.8786029606 & -0.5496297208 \\
\hline $\mathrm{O} 23$ & 0.1672836373 & 3.4604199936 & -1.7534693071 \\
\hline $\mathrm{C} 24$ & -1.6583623544 & 1.5184782808 & -1.2256571120 \\
\hline $\mathrm{C} 25$ & -2.5790987360 & 1.0576614426 & -0.1163973541 \\
\hline $\mathrm{C} 26$ & -3.9671983906 & 1.2615656738 & -0.2005638359 \\
\hline $\mathrm{C} 27$ & -4.7929811891 & 0.8815506402 & 0.8655301658 \\
\hline $\mathrm{C} 28$ & -4.2103520597 & 0.3092978934 & 2.0042059931 \\
\hline $\mathrm{C} 29$ & -2.8259250607 & 0.1283633306 & 2.0247885148 \\
\hline N30 & -2.0319707079 & 0.4926029199 & 0.9912950974 \\
\hline O31 & 0.5266578545 & 2.1581763501 & 0.3547537446 \\
\hline $\mathrm{O} 32$ & -1.3886071716 & 3.7899628448 & 0.2230640857 \\
\hline H33 & -2.2554921987 & 2.0689602828 & -1.9707071834 \\
\hline H34 & -4.3918984373 & 1.7232851694 & -1.0969613968 \\
\hline H35 & -5.8763162310 & 1.0346274756 & 0.8095786275 \\
\hline H36 & -4.8092325029 & 0.0047304466 & 2.8682707988 \\
\hline H37 & -2.3162511229 & -0.3148109750 & 2.8838800864 \\
\hline $\mathrm{C} 38$ & 0.2710548716 & 0.2711024528 & 2.9621862309 \\
\hline C39 & 0.5013162480 & -0.7513316862 & 3.9067227724 \\
\hline $\mathrm{C} 40$ & 0.0937258326 & 1.5908390268 & 3.4298238279 \\
\hline H41 & -0.0937102497 & 2.3958713805 & 2.7118056291 \\
\hline $\mathrm{C} 42$ & 0.1584191097 & 1.8812941847 & 4.8025231175 \\
\hline $\mathrm{H} 43$ & 0.6441780302 & -1.7859566757 & 3.5752050259 \\
\hline
\end{tabular}




$\begin{array}{llrl}\text { C44 } & 0.5607220774 & -0.4591262546 & 5.2812446649 \\ \text { H45 } & 0.0234620856 & 2.9159505355 & 5.1393320616 \\ \text { C46 } & 0.3906044302 & 0.8579269466 & 5.7353696076 \\ \text { H47 } & 0.4323927620 & 1.0851647769 & 6.8062904825 \\ \text { H48 } & 0.7399180705 & -1.2691939354 & 5.9979317369\end{array}$


$\mathrm{TS}_{7-26}$ (TFE)

The total Gibbs free energy, Gtot (Htot - T*S): $\quad-1814.237049$ hartrees

\begin{tabular}{|c|c|c|c|}
\hline $\mathrm{C} 1$ & 0.1999703415 & -0.5242380363 & -4.7247729899 \\
\hline $\mathrm{C} 2$ & -0.6784819325 & 0.3252403029 & -4.0443087423 \\
\hline $\mathrm{H} 3$ & 0.1562858415 & -0.6021895745 & -5.8175272853 \\
\hline $\mathrm{C} 4$ & 1.1564619793 & -1.2392863265 & -4.0041877089 \\
\hline C5 & -0.6319298889 & 0.4036161130 & -2.6380328507 \\
\hline H6 & -1.4171255454 & 0.9247308001 & -4.5844827131 \\
\hline $\mathrm{C} 7$ & 4.3293925258 & -2.8218437235 & -1.2749780758 \\
\hline $\mathrm{C} 8$ & 1.1989391089 & -1.1332967383 & -2.6008811499 \\
\hline $\mathrm{H} 9$ & 1.8942540887 & -1.8611302961 & -4.5179735167 \\
\hline $\mathrm{C} 10$ & 3.3081600951 & -2.4757671347 & -2.1667381053 \\
\hline N11 & 0.2561925981 & -0.3631768376 & -1.9496790496 \\
\hline C12 & 4.2789117026 & -2.3619320802 & 0.0516318157 \\
\hline C13 & 2.2255998443 & -1.6830393793 & -1.7238519613 \\
\hline C14 & 3.1893943310 & -1.6025237533 & 0.5008369769 \\
\hline $\mathrm{C} 15$ & 2.1134524064 & -1.2749835281 & -0.3521691828 \\
\hline H16 & 5.1712937341 & -3.4364767084 & -1.6150962421 \\
\hline $\mathrm{H} 17$ & 3.3613286980 & -2.8136853208 & -3.2062592986 \\
\hline H18 & 5.0979906492 & -2.5861289458 & 0.7433966775 \\
\hline H19 & 3.1772899666 & -1.2453703863 & 1.5356982010 \\
\hline $\operatorname{Pt} 20$ & 0.3761086567 & -0.4260285001 & 0.0718599812 \\
\hline $\mathrm{H} 21$ & 1.5280204000 & -0.3217738833 & 2.1919755028 \\
\hline S22 & -0.4937284250 & 2.9788639640 & -1.4404219284 \\
\hline $\mathrm{O} 23$ & 0.9557232528 & 2.6329736148 & -1.6384148271 \\
\hline $\mathrm{C} 24$ & -1.5160234277 & 1.3839697813 & -1.9326196216 \\
\hline $\mathrm{C} 25$ & -2.3350349659 & 0.8854838007 & -0.7837216447 \\
\hline $\mathrm{C} 26$ & -3.7168258914 & 1.1580928890 & -0.7479485784 \\
\hline $\mathrm{C} 27$ & -4.4969849342 & 0.7034110860 & 0.3180003059 \\
\hline $\mathrm{C} 28$ & -3.8799813752 & -0.0304861942 & 1.3401399670 \\
\hline $\mathrm{C} 29$ & -2.5030529771 & -0.2567671839 & 1.2470789807 \\
\hline N30 & -1.7489015264 & 0.1820208943 & 0.2199152936 \\
\hline O31 & -0.8514883759 & 3.2460450144 & 0.0044952369 \\
\hline $\mathrm{O} 32$ & -1.0254132472 & 4.0029020331 & -2.3976332381 \\
\hline H33 & -2.2021187091 & 1.8117455674 & -2.6774216232 \\
\hline H34 & -4.1680882973 & 1.7090733162 & -1.5796130493 \\
\hline H35 & -5.5735598184 & 0.9091859305 & 0.3480012278 \\
\hline H36 & -4.4355335908 & -0.4128774730 & 2.1976790139 \\
\hline H37 & -1.9868291910 & -0.8434138198 & 2.0093141131 \\
\hline C38 & 0.6604200668 & -0.8291919395 & 2.6457971045 \\
\hline C39 & 0.4389697665 & -2.2210312551 & 2.5208635990 \\
\hline $\mathrm{C} 41$ & -0.0655992513 & -0.0837763130 & 3.6126547782 \\
\hline $\mathrm{H} 42$ & 0.1502865567 & 0.9810974397 & 3.7401510167 \\
\hline $\mathrm{C} 43$ & -0.9913763455 & -0.7277184806 & 4.4411294304 \\
\hline H44 & 1.0557223691 & -2.8098350372 & 1.8357012683 \\
\hline
\end{tabular}




$\begin{array}{llll}\text { C45 } & -0.5312046615 & -2.8535470689 & 3.3242348520 \\ \text { H46 } & -1.5301226627 & -0.1648051002 & 5.2106120953 \\ \text { C47 } & -1.2393590184 & -2.1078893597 & 4.2773123511 \\ \text { H48 } & -1.9769781943 & -2.6059579835 & 4.9199078202 \\ \text { H49 } & -0.7142821929 & -3.9283350836 & 3.2246897378 \\ \text { O50 } & 1.3443988774 & 1.9897158832 & 1.3223700983 \\ \text { H51 } & 0.4835866592 & 2.4084591102 & 1.0660650457 \\ \text { H52 } & 1.8110956354 & 2.0380272016 & 0.4621470659\end{array}$


$\mathrm{TS}_{10-26}$ (TFE)

The total Gibbs free energy, Gtot (Htot - T*S): $\quad-2190.170486$ hartrees

\begin{tabular}{|c|c|c|c|}
\hline $\mathrm{C} 1$ & 0.1482947056 & -0.7707947375 & -4.7558591185 \\
\hline $\mathrm{C} 2$ & -0.7035080166 & 0.1212143015 & -4.0965788482 \\
\hline $\mathrm{H} 3$ & 0.0795310675 & -0.8993933859 & -5.8399918910 \\
\hline $\mathrm{C} 4$ & 1.1131077673 & -1.4599800700 & -4.0197720630 \\
\hline $\mathrm{C} 5$ & -0.6277689166 & 0.2731983269 & -2.7025497580 \\
\hline H6 & -1.4239312352 & 0.7278972661 & -4.6514436067 \\
\hline $\mathrm{C} 7$ & 4.3275376191 & -2.9467489583 & -1.3079564175 \\
\hline $\mathrm{C} 8$ & 1.1936441212 & -1.2757274155 & -2.6317891330 \\
\hline $\mathrm{H} 9$ & 1.8331128303 & -2.1173874143 & -4.5148316322 \\
\hline $\mathrm{C} 10$ & 3.2920858847 & -2.6128546706 & -2.1867586710 \\
\hline N11 & 0.2688064114 & -0.4705488483 & -1.9929135676 \\
\hline C12 & 4.3201867145 & -2.4248397607 & -0.0036284445 \\
\hline C13 & 2.2428014630 & -1.7766516337 & -1.7535032628 \\
\hline C14 & 3.2697515491 & -1.5999878279 & 0.4343973524 \\
\hline $\mathrm{C} 15$ & 2.1934557016 & -1.2774906534 & -0.4146903497 \\
\hline H16 & 5.1427236368 & -3.5963793533 & -1.6410592987 \\
\hline $\mathrm{H} 17$ & 3.3056278929 & -3.0016079555 & -3.2104404467 \\
\hline H18 & 5.1400046169 & -2.6602098013 & 0.6842079693 \\
\hline H19 & 3.3109288904 & -1.2215929389 & 1.4602569487 \\
\hline $\operatorname{Pt} 20$ & 0.4729669817 & -0.3302622653 & -0.0104117145 \\
\hline $\mathrm{H} 21$ & 1.6007720444 & -0.5028445546 & 2.1450966152 \\
\hline S22 & -0.5223902715 & 2.9805461505 & -1.8796269917 \\
\hline $\mathrm{O} 23$ & 0.6636395958 & 2.7114192231 & -0.9700562690 \\
\hline $\mathrm{C} 24$ & -1.4799446564 & 1.3240580136 & -2.0527185541 \\
\hline $\mathrm{C} 25$ & -2.2079334945 & 1.0076430523 & -0.7816853281 \\
\hline $\mathrm{C} 26$ & -3.5399858880 & 1.4344487669 & -0.6371063736 \\
\hline $\mathrm{C} 27$ & -4.2317022722 & 1.1714174303 & 0.5469406696 \\
\hline $\mathrm{C} 28$ & -3.5703929094 & 0.4776687314 & 1.5695109901 \\
\hline $\mathrm{C} 29$ & -2.2440412241 & 0.0980743868 & 1.3712150386 \\
\hline N30 & -1.5642257737 & 0.3654907063 & 0.2276604702 \\
\hline O31 & -1.5471708040 & 3.8937836399 & -1.2864227201 \\
\hline $\mathrm{O} 32$ & -0.0953613008 & 3.2813698530 & -3.2808343018 \\
\hline H33 & -2.2328777806 & 1.6299402950 & -2.7957464825 \\
\hline H34 & -4.0153508731 & 1.9800700221 & -1.4570161218 \\
\hline H35 & -5.2691173006 & 1.4985529729 & 0.6669165211 \\
\hline H36 & -4.0654575313 & 0.2323293966 & 2.5134401674 \\
\hline H37 & -1.6858044721 & -0.4342430622 & 2.1416252435 \\
\hline C38 & 0.8196365866 & -1.0147105110 & 2.7231682906 \\
\hline C39 & 0.5461465231 & -2.3807839669 & 2.5101280978 \\
\hline $\mathrm{C} 41$ & 0.1856194054 & -0.3096201070 & 3.7669302985 \\
\hline $\mathrm{H} 42$ & 0.4094162176 & 0.7498786392 & 3.9129556386 \\
\hline $\mathrm{C} 43$ & -0.7172528670 & -0.9791094681 & 4.6024613647 \\
\hline H44 & 1.0674286735 & -2.9202098863 & 1.7140560156 \\
\hline
\end{tabular}




$\begin{array}{llll}\text { C45 } & -0.3817860913 & -3.0383915857 & 3.3347397478 \\ \text { H46 } & -1.2021823601 & -0.4451260941 & 5.4264646808 \\ \text { C47 } & -1.0078141612 & -2.3390820361 & 4.3784368280 \\ \text { H48 } & -1.7219511725 & -2.8567444451 & 5.0283123824 \\ \text { H49 } & -0.6081691949 & -4.0969453959 & 3.1701520047 \\ \text { O50 } & 0.9096533696 & 1.8119532292 & 1.4373836876 \\ \text { H51 } & 0.6396756116 & 2.2476754131 & 0.5661359226 \\ \text { C51 } & 2.2107556605 & 2.2955537579 & 1.7275029653 \\ \text { H53 } & 2.8488099125 & 1.4821268642 & 2.1173508266 \\ \text { H54 } & 2.7006397670 & 2.7280020923 & 0.8368257662 \\ \text { C54 } & 2.1370543132 & 3.3688827917 & 2.8056643222 \\ \text { F55 } & 1.3740779892 & 4.4241435769 & 2.4264897259 \\ \text { F56 } & 1.6048577386 & 2.8836434194 & 3.9671013773 \\ \text { F57 } & 3.3835164984 & 3.8335471304 & 3.0954154903\end{array}$


$\mathrm{TS}_{26-27}$ (TFE)

The total Gibbs free energy, Gtot (Htot - T*S): $\quad-1737.891776$ hartrees

\begin{tabular}{|c|c|c|c|}
\hline $\mathrm{C} 1$ & 0.2435766492 & -0.3245815906 & -3.8804739245 \\
\hline $\mathrm{C} 2$ & -0.7729091476 & 0.4222533743 & -3.2716242996 \\
\hline $\mathrm{H} 3$ & 0.2823929368 & -0.4171541326 & -4.9708169268 \\
\hline $\mathrm{C} 4$ & 1.2354623745 & -0.9140202048 & -3.0911879069 \\
\hline $\mathrm{C} 5$ & -0.8149495609 & 0.5156473162 & -1.8709966346 \\
\hline H6 & -1.5248202746 & 0.9456663220 & -3.8687709716 \\
\hline $\mathrm{C} 7$ & 4.4029628969 & -2.0869607412 & -0.1675353602 \\
\hline $\mathrm{C} 8$ & 1.1688838851 & -0.7938084109 & -1.6931644355 \\
\hline H9 & 2.0658119584 & -1.4524600587 & -3.5558671723 \\
\hline $\mathrm{C} 10$ & 3.4142002483 & -1.8201071627 & -1.1218054631 \\
\hline N11 & 0.1057084030 & -0.1380974463 & -1.1191771772 \\
\hline C12 & 4.1782406208 & -1.7524298017 & 1.1782065078 \\
\hline C13 & 2.1966178058 & -1.2180967800 & -0.7369251550 \\
\hline C14 & 2.9594029937 & -1.1755538547 & 1.5773217742 \\
\hline $\mathrm{C} 15$ & 1.9548364952 & -0.8990187713 & 0.6345126819 \\
\hline H16 & 5.3493933190 & -2.5437711006 & -0.4747947936 \\
\hline $\mathrm{H} 17$ & 3.6025863426 & -2.0688963451 & -2.1713995599 \\
\hline $\mathrm{H} 18$ & 4.9540105047 & -1.9467752539 & 1.9277556871 \\
\hline H19 & 2.8060323494 & -0.9352364363 & 2.6335129220 \\
\hline $\mathrm{Pt} 20$ & 0.0896566068 & -0.1984311602 & 0.9685204444 \\
\hline $\mathrm{H} 21$ & 0.2379803512 & -1.1802283957 & 2.2073738166 \\
\hline $\mathrm{S} 22$ & -0.8037336809 & 2.9961136197 & -0.6072209216 \\
\hline $\mathrm{O} 23$ & -0.1634740499 & 3.5018725889 & -1.8653413554 \\
\hline $\mathrm{C} 24$ & -1.7772419116 & 1.4534476793 & -1.1965022006 \\
\hline $\mathrm{C} 25$ & -2.6434269610 & 0.9200850891 & -0.0888448416 \\
\hline $\mathrm{C} 26$ & -4.0306722343 & 1.1568633000 & -0.1335102644 \\
\hline $\mathrm{C} 27$ & -4.8577009210 & 0.6942251024 & 0.8935954187 \\
\hline $\mathrm{C} 28$ & -4.2738151521 & -0.0039078326 & 1.9589725426 \\
\hline $\mathrm{C} 29$ & -2.8944081424 & -0.2092901111 & 1.9408514028 \\
\hline N30 & -2.0833212424 & 0.2569457833 & 0.9602606695 \\
\hline $\mathrm{O} 31$ & 0.1788889393 & 2.4608514372 & 0.4100774461 \\
\hline $\mathrm{O} 32$ & -1.8642459569 & 3.8842608857 & -0.0302465292 \\
\hline H33 & -2.4381115910 & 1.8743963452 & -1.9703346211 \\
\hline H34 & -4.4504115322 & 1.6985021169 & -0.9863970595 \\
\hline H35 & -5.9374099354 & 0.8747292084 & 0.8623987740 \\
\hline H36 & -4.8702945654 & -0.4020285190 & 2.7854428207 \\
\hline H37 & -2.4054455921 & -0.7606608713 & 2.7439335416 \\
\hline C38 & 0.2858205542 & 0.0684124889 & 3.0799602431 \\
\hline C39 & -0.3865414339 & -0.5315844520 & 4.1662024324 \\
\hline $\mathrm{C} 41$ & 1.1027754517 & 1.1995757765 & 3.3038310770 \\
\hline $\mathrm{H} 42$ & 1.6455994706 & 1.6623863496 & 2.4759860549 \\
\hline $\mathrm{C} 43$ & 1.1767470618 & 1.7597527325 & 4.5864423309 \\
\hline $\mathrm{H} 44$ & -0.9503824488 & -1.4646374149 & 4.0404138972 \\
\hline
\end{tabular}




$\begin{array}{lrrr}\text { C45 } & -0.2736122696 & 0.0197637832 & 5.4544107918 \\ \text { H46 } & 1.7795485160 & 2.6613503083 & 4.7402043401 \\ \text { C47 } & 0.4880190406 & 1.1766846649 & 5.6630772367 \\ \text { H48 } & 0.5642174752 & 1.6147521940 & 6.6640984767 \\ \text { H49 } & -0.7822970503 & -0.4684129619 & 6.2927892453\end{array}$




\section{$\mathrm{TS}_{26-23}$ (gas phase)}

The total Gibbs free energy, Gtot (Htot - T*S): $\quad-1737.862556$ hartrees

Gibbs solvation energy --20.3507 kcal/mol

This TS could not be located in TFE; the Gibbs energy is calculated using Gsolv corrections to the gas phase energy above.

Other Gibbs solvation energies used for this and similar calculations;

26,

$\mathrm{C} 1$

$\mathrm{C} 2$

$\mathrm{H} 3$

$\mathrm{C} 4$

C5

H6

C7

C8

H9

C10

N11

C12

C13

C14

C15

H16

H17

H18

H19

Pt20

H21

S22

O23

C24

C25

C26

C27

C28

C29

N30

O31

O32

H33

H34

H35

H36 $-22.0457 \mathrm{kcal} / \mathrm{mol}$

$$
\begin{array}{r}
-0.0397191138 \\
-0.8480663623 \\
-0.1864207662 \\
0.9528786532 \\
-0.6587431067 \\
-1.6334045460 \\
4.0729116772
\end{array}
$$$$
1.1376979289
$$$$
1.5976342192
$$$$
3.1103287078
$$$$
0.3247300627
$$$$
4.0812520282
$$$$
2.1443638541
$$

3.1245779826

2.1244474646

4.8228975013

3.1134024645

4.8504092697

3.1818302648

0.6817791895

1.6425901672

$-0.5727344486$

0.4693329993

$-1.5483131132$

$-2.4163243360$

$-3.8095716944$

$-4.5697902376$

$-3.9224275034$

$-2.5308939365$

$-1.7987500968$

$-0.0343574506$

$-1.6310985373$

$-2.1868654017$

$-4.2792758456$

$-5.6560478081$

$-4.4790481137$
$-0.7058860503$

0.2720031487

$-0.9842811875$

$-1.3228435898$

0.6221959614

0.7730257423

$-2.8301863969$

$-0.9483822983$

$-2.0883956038$

$-2.4274444176$

0.0167348954

$-2.2537910765$

$-1.4618803287$

$-1.2978894159$

$-0.8931255616$

$-3.5766886345$

$-2.8612710998$

$-2.5453759384$

$-0.8541047185$

0.4315939772

0.9409022002

3.1814304905

3.3751301082

1.6483623848

1.1283263633

1.3193778071

0.8226560046

0.1519132408

0.0173096699

0.4946962615

2.7194641956

4.2151401173

2.0796416207

1.8529780810

0.9549526352

$-0.2594597397$
$-3.7058936000$

$-3.1163655919$

$-4.7535217430$

$-2.9467619407$

$-1.7714162138$

$-3.6862532755$

$-0.1182729040$

$-1.6062108973$

$-3.3834168656$

$-1.0442439489$

$-1.0515323864$

1.1641682323

$-0.6929847888$

1.5293487815

0.6208328596

$-0.3939456002$

$-2.0497591630$

1.8871552125

2.5279273742

0.9018594182

2.3665174786

$-0.5240932161$

$-1.5642166925$

$-1.1315099213$

$-0.0176136460$

$-0.0256463095$

1.0368445284

2.0837963201

2.0233639176

1.0009538339

0.8364144952

$-0.3866339474$

$-1.9161074624$

$-0.8562742362$

1.0462114703

2.9297260151 


$\begin{array}{lrrr}\text { H37 } & -1.9683755518 & -0.4872596241 & 2.8161910789 \\ \text { C38 } & 0.7661511457 & 0.6996551686 & 3.1227253157 \\ \text { C39 } & 0.7783065379 & -0.5123914355 & 3.8512525764 \\ \text { C40 } & 0.1240670382 & 1.8427778243 & 3.6530199581 \\ \text { H41 } & 0.1146181145 & 2.7643988963 & 3.0657312473 \\ \text { C42 } & -0.5181664455 & 1.7588965662 & 4.8922826451 \\ \text { H43 } & 1.2834255258 & -1.3898573736 & 3.4407423541 \\ \text { C44 } & 0.1214142749 & -0.5844223342 & 5.0861618745 \\ \text { H45 } & -1.0233301406 & 2.6393012822 & 5.3007185991 \\ \text { C46 } & -0.5233360661 & 0.5490323054 & 5.6064271624 \\ \text { H47 } & -1.0309303016 & 0.4896200363 & 6.5746052744 \\ \text { H48 } & 0.1136978778 & -1.5260973127 & 5.6435823076\end{array}$


$\mathrm{TS}_{11-22}$ (TFE)

The total Gibbs free energy, Gtot (Htot - T*S): $\quad-1814.221863$ hartrees

\begin{tabular}{|c|c|c|c|}
\hline $\mathrm{C} 1$ & 1.1812715916 & 0.4778007428 & -4.0545895630 \\
\hline $\mathrm{C} 2$ & 0.0452262642 & 1.0765323239 & -3.4980884154 \\
\hline $\mathrm{H} 3$ & 1.4340323857 & 0.6373136845 & -5.1079452824 \\
\hline $\mathrm{C} 4$ & 1.9920480488 & -0.3128154534 & -3.2398446537 \\
\hline $\mathrm{C} 5$ & -0.2904477281 & 0.8559158414 & -2.1527977076 \\
\hline H6 & -0.6114080592 & 1.7067942779 & -4.1054037159 \\
\hline $\mathrm{C} 7$ & 4.4146736076 & -2.4516041414 & -0.1409344365 \\
\hline $\mathrm{C} 8$ & 1.6621277597 & -0.4877540949 & -1.8861921251 \\
\hline H9 & 2.8967873061 & -0.7810686091 & -3.6374084028 \\
\hline $\mathrm{C} 10$ & 3.6840341228 & -1.8630703905 & -1.1794671884 \\
\hline N11 & 0.5114132167 & 0.0822300351 & -1.3642188792 \\
\hline $\mathrm{C} 12$ & 3.9415651193 & -2.3646975720 & 1.1819216417 \\
\hline $\mathrm{C} 13$ & 2.4709181501 & -1.1964998076 & -0.9002306737 \\
\hline C14 & 2.7278856428 & -1.7171979404 & 1.4677913770 \\
\hline $\mathrm{C} 15$ & 1.9715228318 & -1.1331999099 & 0.4340447166 \\
\hline H16 & 5.3528321748 & -2.9728948281 & -0.3568210263 \\
\hline H17 & 4.0614046238 & -1.9242661917 & -2.2066705548 \\
\hline H18 & 4.5200997796 & -2.8116540371 & 1.9987172785 \\
\hline H19 & 2.3776818059 & -1.6607698159 & 2.5040612866 \\
\hline Pt20 & 0.2443246000 & -0.2104796154 & 0.6347620419 \\
\hline $\mathrm{S} 21$ & -1.6025302309 & 2.1576381834 & 0.0575836248 \\
\hline $\mathrm{O} 22$ & -0.3285883418 & 2.9346802484 & 0.2313043284 \\
\hline $\mathrm{C} 23$ & -1.6031746404 & 1.4458420480 & -1.6716148791 \\
\hline $\mathrm{C} 24$ & -2.7765621943 & 0.4779842563 & -1.8534692314 \\
\hline $\mathrm{C} 25$ & -4.1034289314 & 0.9490709019 & -1.8073713265 \\
\hline $\mathrm{C} 26$ & -5.1448043863 & 0.0358792337 & -2.0098339306 \\
\hline $\mathrm{C} 27$ & -4.8294754337 & -1.3065758735 & -2.2668520665 \\
\hline $\mathrm{C} 28$ & -3.4771551247 & -1.6727083237 & -2.3023763575 \\
\hline N29 & -2.4617676925 & -0.8089167620 & -2.1004351064 \\
\hline $\mathrm{O} 30$ & -1.6624847986 & 0.8984019736 & 0.9528181020 \\
\hline $\mathrm{O} 31$ & -2.8520157329 & 2.9620606098 & 0.1779867473 \\
\hline H32 & -1.7944188259 & 2.3499599162 & -2.2789243012 \\
\hline H33 & -4.3070284088 & 2.0037998853 & -1.6019859598 \\
\hline H34 & -6.1873472284 & 0.3698983582 & -1.9748949666 \\
\hline H35 & -5.6111115522 & -2.0521192434 & -2.4481623218 \\
\hline H36 & -3.1891904289 & -2.7108273926 & -2.5154565208 \\
\hline C37 & -0.7181967154 & -2.4014251674 & 1.7917170232 \\
\hline C38 & -0.6502160942 & -1.7344971842 & 3.0392830794 \\
\hline H39 & 0.1550564633 & -2.9377951173 & 1.4093312428 \\
\hline $\mathrm{C} 40$ & -1.9698481442 & -2.5486685683 & 1.1463634310 \\
\hline C41 & -1.8169839723 & -1.1958833302 & 3.6147209539 \\
\hline H42 & 0.3008446838 & -1.6763690483 & 3.5786647276 \\
\hline $\mathrm{C} 43$ & -3.1216357979 & -2.0074275265 & 1.7233526748 \\
\hline
\end{tabular}




$\begin{array}{lrrr}\text { H44 } & -2.0258974235 & -3.0876938964 & 0.1957361354 \\ \text { H45 } & -1.7624258611 & -0.6879424846 & 4.5838985846 \\ \text { C46 } & -3.0462862023 & -1.3287364328 & 2.9555439802 \\ \text { H47 } & -3.9546894388 & -0.9111661794 & 3.4037099194 \\ \text { H48 } & -4.0869740152 & -2.1120447748 & 1.2172273019 \\ \text { O49 } & 0.4665223973 & 1.1378298365 & 2.6962086411 \\ \text { H50 } & -0.5119768520 & 1.1762831801 & 2.7978641735 \\ \text { H51 } & 0.6350825386 & 1.9204003729 & 2.1222195162\end{array}$


TS $_{12-22}$ (TFE)

The total Gibbs free energy, Gtot (Htot - T*S): $\quad-2190.158160$ hartrees

\begin{tabular}{|c|c|c|c|}
\hline $\mathrm{C} 1$ & 1.5046676944 & 0.9916350178 & -4.0100342667 \\
\hline $\mathrm{C} 2$ & 0.3143869027 & 1.4379922427 & -3.4240671318 \\
\hline $\mathrm{H} 3$ & 1.8018679069 & 1.3408148331 & -5.0041716782 \\
\hline $\mathrm{C} 4$ & 2.3061551034 & 0.0961898639 & -3.3027002846 \\
\hline $\mathrm{C} 5$ & -0.0691693586 & 0.9772615430 & -2.1554698612 \\
\hline H6 & -0.3430224303 & 2.1376996743 & -3.9492700970 \\
\hline $\mathrm{C} 7$ & 4.6043479880 & -2.5867654002 & -0.5475786193 \\
\hline $\mathrm{C} 8$ & 1.9207725328 & -0.3298044872 & -2.0217528050 \\
\hline H9 & 3.2448466548 & -0.2694453178 & -3.7284186604 \\
\hline $\mathrm{C} 10$ & 3.9374623206 & -1.7829027263 & -1.4787773440 \\
\hline N11 & 0.7339414234 & 0.1162402754 & -1.4652978253 \\
\hline $\mathrm{C} 12$ & 4.0274816878 & -2.8232486893 & 0.7135779121 \\
\hline $\mathrm{C} 13$ & 2.6849613735 & -1.2192497703 & -1.1549996053 \\
\hline C14 & 2.7789855550 & -2.2703724266 & 1.0437313443 \\
\hline $\mathrm{C} 15$ & 2.0877058321 & -1.4708923811 & 0.1143732246 \\
\hline H16 & 5.5757737364 & -3.0241703725 & -0.7992437512 \\
\hline H17 & 4.3986549418 & -1.5922402104 & -2.4542161921 \\
\hline H18 & 4.5530449242 & -3.4439996545 & 1.4487091316 \\
\hline H19 & 2.3529817172 & -2.4655783504 & 2.0341931431 \\
\hline Pt20 & 0.3795868683 & -0.5473969997 & 0.4237009620 \\
\hline $\mathrm{S} 21$ & -1.4200704469 & 2.0024468759 & 0.1403683671 \\
\hline $\mathrm{O} 22$ & -0.1838002236 & 2.8282997456 & 0.2972144265 \\
\hline $\mathrm{C} 23$ & -1.4218975695 & 1.4193410702 & -1.6360189598 \\
\hline $\mathrm{C} 24$ & -2.5293549148 & 0.4080941039 & -1.9403242585 \\
\hline $\mathrm{C} 25$ & -3.8844489619 & 0.7721743731 & -1.8155635080 \\
\hline $\mathrm{C} 26$ & -4.8633740819 & -0.1637647376 & -2.1699873227 \\
\hline $\mathrm{C} 27$ & -4.4616344590 & -1.4213530523 & -2.6448745113 \\
\hline $\mathrm{C} 28$ & -3.0879397436 & -1.6841021738 & -2.7365949332 \\
\hline N29 & -2.1318586035 & -0.7969854322 & -2.3953804120 \\
\hline $\mathrm{O} 30$ & -1.3888589294 & 0.6884902151 & 0.9748722494 \\
\hline $\mathrm{O} 31$ & -2.7104228217 & 2.7180001280 & 0.3501215278 \\
\hline H32 & -1.6689099474 & 2.3664500563 & -2.1509899351 \\
\hline H33 & -4.1573006148 & 1.7646714281 & -1.4457320902 \\
\hline H34 & -5.9257045742 & 0.0906407020 & -2.0880164038 \\
\hline H35 & -5.1917720735 & -2.1797717214 & -2.9464784583 \\
\hline H36 & -2.7329229084 & -2.6517244137 & -3.1160121676 \\
\hline C37 & -0.6401203694 & -2.7755734627 & 1.4368425193 \\
\hline C38 & -0.7672304326 & -2.3209043057 & 2.7710847856 \\
\hline H39 & 0.2866921707 & -3.2557454804 & 1.1088420004 \\
\hline $\mathrm{C} 40$ & -1.7855191739 & -2.8287122329 & 0.6034820904 \\
\hline C41 & -2.0138208867 & -1.8833564383 & 3.2487637774 \\
\hline H42 & 0.1029918828 & -2.3258016401 & 3.4342022779 \\
\hline $\mathrm{C} 43$ & -3.0231304383 & -2.3980071007 & 1.0896750595 \\
\hline
\end{tabular}




$\begin{array}{lccc}\text { H44 } & -1.6902770783 & -3.2117724736 & -0.4169623275 \\ \text { H45 } & -2.1096938936 & -1.5267890453 & 4.2802019785 \\ \text { C46 } & -3.1372977167 & -1.9224793023 & 2.4096890909 \\ \text { H47 } & -4.1111905549 & -1.5892833614 & 2.7857763489 \\ \text { H48 } & -3.9057140742 & -2.4304759108 & 0.4428595088 \\ \text { O49 } & 0.6096229190 & 0.2785851298 & 2.7940175952 \\ \text { H50 } & -0.2722223576 & 0.6679879044 & 2.5621531336 \\ \text { C51 } & 1.5477551377 & 1.3614300036 & 2.8315503900 \\ \text { H52 } & 2.5533486660 & 0.9334568832 & 2.9596137630 \\ \text { H53 } & 1.5109391162 & 1.9639123918 & 1.9075835895 \\ \text { C54 } & 1.2396277284 & 2.2735545725 & 4.0109983054 \\ \text { F55 } & -0.0347496771 & 2.7545641523 & 3.9230091916 \\ \text { F56 } & 1.3479020223 & 1.6379674702 & 5.2053310649 \\ \text { F57 } & 2.0879290319 & 3.3349542173 & 4.0246858104\end{array}$


$\mathrm{TS}_{22-23}$ (TFE)

The total Gibbs free energy, Gtot (Htot - T*S): $\quad-1737.894801$ hartrees

\begin{tabular}{|c|c|c|c|}
\hline $\mathrm{C} 1$ & 1.9111090901 & 0.9620970671 & -4.1083061112 \\
\hline $\mathrm{C} 2$ & 0.7349953370 & 1.5027885290 & -3.5764183714 \\
\hline $\mathrm{H} 3$ & 2.2803295621 & 1.2839297861 & -5.0875404482 \\
\hline $\mathrm{C} 4$ & 2.5924179566 & -0.0096354543 & -3.3776715465 \\
\hline $\mathrm{C} 5$ & 0.2698912292 & 1.0843985512 & -2.3204927462 \\
\hline H6 & 0.1530878973 & 2.2426784900 & -4.1337705488 \\
\hline $\mathrm{C} 7$ & 4.3817483291 & -3.1344353725 & -0.7604780555 \\
\hline $\mathrm{C} 8$ & 2.1136443289 & -0.4046761150 & -2.1170779719 \\
\hline H9 & 3.4993343104 & -0.4703875886 & -3.7769336158 \\
\hline $\mathrm{C} 10$ & 3.8769654937 & -2.1548108626 & -1.6220441655 \\
\hline N11 & 0.9761478303 & 0.1732574720 & -1.5905285461 \\
\hline $\mathrm{C} 12$ & 3.7253136587 & -3.3923039717 & 0.4546910125 \\
\hline $\mathrm{C} 13$ & 2.7132528738 & -1.4358974729 & -1.2750591860 \\
\hline C14 & 2.5656224219 & -2.6818367642 & 0.8070536672 \\
\hline $\mathrm{C} 15$ & 2.0303629762 & -1.6963784993 & -0.0486096041 \\
\hline H16 & 5.2847353488 & -3.6906088832 & -1.0313987357 \\
\hline H17 & 4.3953630899 & -1.9538660011 & -2.5660906794 \\
\hline H18 & 4.1188569539 & -4.1512576372 & 1.1411368604 \\
\hline H19 & 2.0975797837 & -2.9114267851 & 1.7700111794 \\
\hline Pt20 & 0.4775850287 & -0.5020481193 & 0.2813248305 \\
\hline $\mathrm{S} 21$ & -1.0549024449 & 2.2753448056 & -0.1235064535 \\
\hline $\mathrm{O} 22$ & 0.1996663801 & 3.0799806882 & -0.0053694179 \\
\hline $\mathrm{C} 23$ & -1.0726817529 & 1.5996189890 & -1.8619733867 \\
\hline $\mathrm{C} 24$ & -2.2012501467 & 0.5892606121 & -2.0517929004 \\
\hline $\mathrm{C} 25$ & -3.5286753634 & 1.0373792178 & -2.1979131989 \\
\hline $\mathrm{C} 26$ & -4.5394801367 & 0.0849751195 & -2.3729986396 \\
\hline $\mathrm{C} 27$ & -4.1938855560 & -1.2742708923 & -2.4020617404 \\
\hline $\mathrm{C} 28$ & -2.8428005150 & -1.6174148171 & -2.2539027818 \\
\hline N29 & -1.8585651268 & -0.7139342532 & -2.0851108103 \\
\hline $\mathrm{O} 30$ & -1.0667708710 & 1.0070371865 & 0.7570163957 \\
\hline $\mathrm{O} 31$ & -2.3304515823 & 3.0320464867 & 0.0395248551 \\
\hline H32 & -1.3021847097 & 2.5032663062 & -2.4527179294 \\
\hline H33 & -3.7581323192 & 2.1068913986 & -2.1675955148 \\
\hline H34 & -5.5817594109 & 0.4001973747 & -2.4925459313 \\
\hline H35 & -4.9495729160 & -2.0529654164 & -2.5472150778 \\
\hline H36 & -2.5293816376 & -2.6693020379 & -2.2821775939 \\
\hline C37 & -0.6936798947 & -2.7383359412 & 1.8377665407 \\
\hline C38 & -0.2679125234 & -1.4445943582 & 2.2396689438 \\
\hline H39 & -0.0295266397 & -3.3772827639 & 1.2492433996 \\
\hline $\mathrm{C} 40$ & -1.9693187154 & -3.1913976127 & 2.1977127649 \\
\hline C41 & -1.1094164663 & -0.6394052492 & 3.0497905272 \\
\hline H42 & 0.8236445989 & -1.1681368749 & 2.2280626493 \\
\hline $\mathrm{C} 43$ & -2.7997278505 & -2.3801222627 & 2.9879370437 \\
\hline
\end{tabular}




$\begin{array}{llrl}\text { H44 } & -2.3121831258 & -4.1797089637 & 1.8739655275 \\ \text { H45 } & -0.7637714979 & 0.3471481155 & 3.3698117744 \\ \text { C46 } & -2.3689184427 & -1.1113971975 & 3.4228883585 \\ \text { H47 } & -3.0225176407 & -0.4968368336 & 4.0506200114 \\ \text { H48 } & -3.7927848737 & -2.7424488828 & 3.2778805555\end{array}$




\begin{tabular}{|c|c|c|c|}
\hline \multicolumn{4}{|c|}{ TS $_{23-24}$ (TFE) } \\
\hline $\mathrm{C} 1$ & 0.8759672634 & 1.7461130699 & -4.1935953946 \\
\hline $\mathrm{C} 2$ & -0.0845563178 & 2.3777451306 & -3.3896691952 \\
\hline $\mathrm{H} 3$ & 1.0627453845 & 2.0948696261 & -5.2153200332 \\
\hline $\mathrm{C} 4$ & 1.5726827962 & 0.6462958632 & -3.6910669030 \\
\hline $\mathrm{C} 5$ & -0.2989459384 & 1.9189208266 & -2.0810689174 \\
\hline H6 & -0.6788343616 & 3.2122030574 & -3.7743382747 \\
\hline $\mathrm{C} 7$ & 3.4856979674 & -2.8417016952 & -1.6819019372 \\
\hline $\mathrm{C} 8$ & 1.3360883814 & 0.2179284151 & -2.3711824970 \\
\hline H9 & 2.2961926798 & 0.1179111513 & -4.3181116318 \\
\hline $\mathrm{C} 10$ & 2.9225749960 & -1.7541267629 & -2.3566185417 \\
\hline N11 & 0.4334399224 & 0.8870052440 & -1.5829501029 \\
\hline $\mathrm{C} 12$ & 3.0956160670 & -3.1132060572 & -0.3599848931 \\
\hline $\mathrm{C} 13$ & 1.9572031781 & -0.9382990351 & -1.7234286039 \\
\hline $\mathrm{C} 14$ & 2.1362018912 & -2.3115217489 & 0.2792469572 \\
\hline $\mathrm{C} 15$ & 1.5323722210 & -1.2286050957 & -0.3892437049 \\
\hline H16 & 4.2346605976 & -3.4671892115 & -2.1782442435 \\
\hline H17 & 3.2401474234 & -1.5384022453 & -3.3825090227 \\
\hline H18 & 3.5456047274 & -3.9506852399 & 0.1861777371 \\
\hline H19 & 1.8757188625 & -2.5402494222 & 1.3161355872 \\
\hline Pt20 & 0.2247507227 & 0.0920952268 & 0.3745447479 \\
\hline $\mathrm{H} 21$ & 1.0414719749 & -0.2111189975 & 1.7291612010 \\
\hline S22 & -0.8740785467 & 3.1378481390 & 0.4179699113 \\
\hline $\mathrm{O} 23$ & 0.4643725822 & 3.7638129713 & 0.2017084655 \\
\hline $\mathrm{C} 24$ & -1.4292477263 & 2.4791914772 & -1.2543927600 \\
\hline $\mathrm{C} 25$ & -2.5507045496 & 1.4736078747 & -1.0367158136 \\
\hline $\mathrm{C} 26$ & -3.8975111640 & 1.8518983665 & -1.1736735115 \\
\hline $\mathrm{C} 27$ & -4.8952240194 & 0.8984594653 & -0.9290500936 \\
\hline $\mathrm{C} 28$ & -4.5188831710 & -0.4017285852 & -0.5645622650 \\
\hline $\mathrm{C} 29$ & -3.1523810771 & -0.6901137655 & -0.4489420956 \\
\hline N30 & -2.1899082603 & 0.2231953762 & -0.6757715247 \\
\hline O31 & -0.8298401827 & 1.8708829068 & 1.2977886997 \\
\hline O32 & -1.9660900009 & 4.0471071712 & 0.8712320633 \\
\hline H33 & -1.8271276681 & 3.3758948127 & -1.7583555726 \\
\hline H34 & -4.1557297761 & 2.8763000719 & -1.4597356817 \\
\hline H35 & -5.9533151479 & 1.1670151290 & -1.0206356307 \\
\hline H36 & -5.2656380117 & -1.1771939338 & -0.3658122827 \\
\hline H37 & -2.8087346228 & -1.6896890053 & -0.1589974036 \\
\hline $\mathrm{C} 38$ & -0.2337080394 & -0.8340520795 & 2.2143715850 \\
\hline C39 & -0.5386547566 & -0.0841538806 & 3.3714703293 \\
\hline $\mathrm{C} 40$ & -0.5227422294 & -2.2162579067 & 2.1853882036 \\
\hline H41 & -0.2931941063 & -2.8099186528 & 1.2967089225 \\
\hline $\mathrm{C} 42$ & -1.1378498309 & -2.8276503549 & 3.2881193097 \\
\hline H43 & -0.3106478478 & 0.9843655145 & 3.4029651422 \\
\hline
\end{tabular}




$\begin{array}{llll}\text { C44 } & -1.1400536626 & -0.7091784488 & 4.4735589264 \\ \text { H45 } & -1.3798654373 & -3.8950229016 & 3.2426497045 \\ \text { C46 } & -1.4436282429 & -2.0794574125 & 4.4363168261 \\ \text { H47 } & -1.9117575760 & -2.5649734081 & 5.2994077753 \\ \text { H48 } & -1.3746052206 & -0.1152834158 & 5.3638205204\end{array}$


$\mathbf{T S}_{23-24}$ for $\mathbf{C}_{6} \mathbf{D}_{6}$ substrate (TFE)

The total Gibbs free energy, Gtot (Htot - T*S): $\quad-1737.911075$ hartrees

\begin{tabular}{|c|c|c|c|}
\hline $\mathrm{C} 1$ & 0.8759670000 & 1.7461130000 & -4.1935950000 \\
\hline $\mathrm{C} 2$ & -0.0845560000 & 2.3777450000 & -3.3896690000 \\
\hline $\mathrm{H} 3$ & 1.0627450000 & 2.0948700000 & -5.2153200000 \\
\hline $\mathrm{C} 4$ & 1.5726830000 & 0.6462960000 & -3.6910670000 \\
\hline $\mathrm{C} 5$ & -0.2989460000 & 1.9189210000 & -2.0810690000 \\
\hline H6 & -0.6788340000 & 3.2122030000 & -3.7743380000 \\
\hline $\mathrm{C} 7$ & 3.4856980000 & -2.8417020000 & -1.6819020000 \\
\hline $\mathrm{C} 8$ & 1.3360880000 & 0.2179280000 & -2.3711820000 \\
\hline H9 & 2.2961930000 & 0.1179110000 & -4.3181120000 \\
\hline $\mathrm{C} 10$ & 2.9225750000 & -1.7541270000 & -2.3566190000 \\
\hline N11 & 0.4334400000 & 0.8870050000 & -1.5829500000 \\
\hline $\mathrm{C} 12$ & 3.0956160000 & -3.1132060000 & -0.3599850000 \\
\hline $\mathrm{C} 13$ & 1.9572030000 & -0.9382990000 & -1.7234290000 \\
\hline $\mathrm{C} 14$ & 2.1362020000 & -2.3115220000 & 0.2792470000 \\
\hline $\mathrm{C} 15$ & 1.5323720000 & -1.2286050000 & -0.3892440000 \\
\hline H16 & 4.2346610000 & -3.4671890000 & -2.1782440000 \\
\hline H17 & 3.2401470000 & -1.5384020000 & -3.3825090000 \\
\hline H18 & 3.5456050000 & -3.9506850000 & 0.1861780000 \\
\hline H19 & 1.8757190000 & -2.5402490000 & 1.3161360000 \\
\hline Pt20 & 0.2247510000 & 0.0920950000 & 0.3745450000 \\
\hline $\mathrm{H} 21$ & 1.0414720000 & -0.2111190000 & 1.7291610000 \\
\hline $\mathrm{S} 22$ & -0.8740790000 & 3.1378480000 & 0.4179700000 \\
\hline $\mathrm{O} 23$ & 0.4643730000 & 3.7638130000 & 0.2017080000 \\
\hline $\mathrm{C} 24$ & -1.4292480000 & 2.4791910000 & -1.2543930000 \\
\hline $\mathrm{C} 25$ & -2.5507050000 & 1.4736080000 & -1.0367160000 \\
\hline $\mathrm{C} 26$ & -3.8975110000 & 1.8518980000 & -1.1736740000 \\
\hline $\mathrm{C} 27$ & -4.8952240000 & 0.8984590000 & -0.9290500000 \\
\hline $\mathrm{C} 28$ & -4.5188830000 & -0.4017290000 & -0.5645620000 \\
\hline C29 & -3.1523810000 & -0.6901140000 & -0.4489420000 \\
\hline $\mathrm{N} 30$ & -2.1899080000 & 0.2231950000 & -0.6757720000 \\
\hline O31 & -0.8298400000 & 1.8708830000 & 1.2977890000 \\
\hline $\mathrm{O} 32$ & -1.9660900000 & 4.0471070000 & 0.8712320000 \\
\hline H33 & -1.8271280000 & 3.3758950000 & -1.7583560000 \\
\hline H34 & -4.1557300000 & 2.8763000000 & -1.4597360000 \\
\hline H35 & -5.9533150000 & 1.1670150000 & -1.0206360000 \\
\hline H36 & -5.2656380000 & -1.1771940000 & -0.3658120000 \\
\hline H37 & -2.8087350000 & -1.6896890000 & -0.1589970000 \\
\hline C38 & -0.2337080000 & -0.8340520000 & 2.2143720000 \\
\hline C39 & -0.5386550000 & -0.0841540000 & 3.3714700000 \\
\hline $\mathrm{C} 40$ & -0.5227420000 & -2.2162580000 & 2.1853880000 \\
\hline H41 & -0.2931940000 & -2.8099190000 & 1.2967090000 \\
\hline $\mathrm{C} 42$ & -1.1378500000 & -2.8276500000 & 3.2881190000 \\
\hline $\mathrm{H} 43$ & -0.3106480000 & 0.9843660000 & 3.4029650000 \\
\hline
\end{tabular}




$\begin{array}{llll}\text { C44 } & -1.1400540000 & -0.7091780000 & 4.4735590000 \\ \text { H45 } & -1.3798650000 & -3.8950230000 & 3.2426500000 \\ \text { C46 } & -1.4436280000 & -2.0794570000 & 4.4363170000 \\ \text { H47 } & -1.9117580000 & -2.5649730000 & 5.2994080000 \\ \text { H48 } & -1.3746050000 & -0.1152830000 & 5.3638210000\end{array}$




\section{Crystallographic Details}

\section{Crystal Structure Determination for 7 (Fig. S26)}

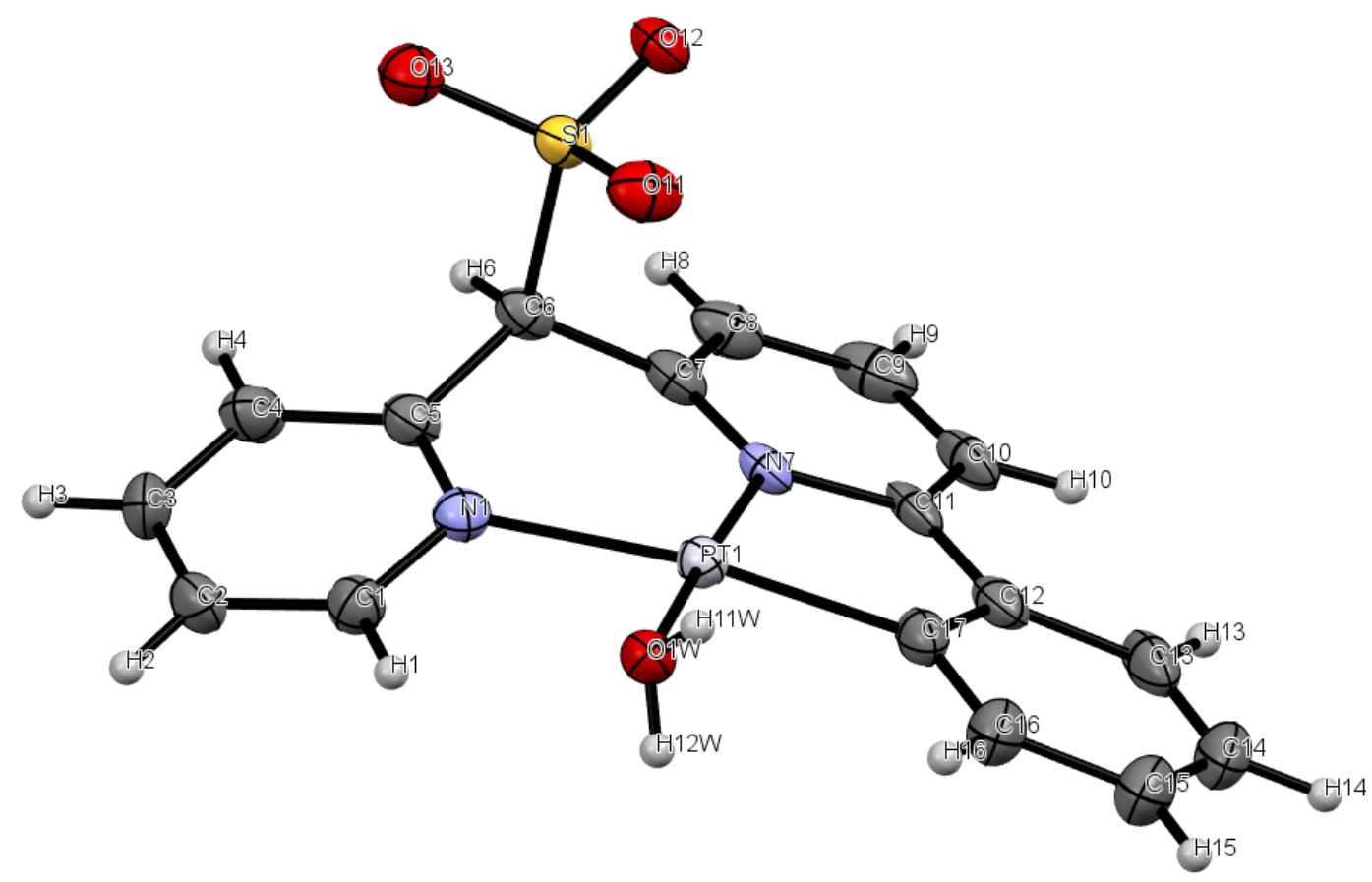

Figure S26. ORTEP plot for 7.

A yellow plate-like specimen of $\mathrm{C}_{17} \mathrm{H}_{22} \mathrm{~N}_{2} \mathrm{O}_{8} \mathrm{PtS}$, approximate dimensions $0.09 \mathrm{~mm} \times 0.19 \mathrm{~mm}$ $\times 0.49 \mathrm{~mm}$, was used for the X-ray crystallographic analysis. The X-ray intensity data were measured on a Bruker APEX-II CCD system equipped with a graphite monochromator and a MoK $\alpha$ sealed tube $(\lambda=0.71073 \AA)$. Data collection temperature was $100 \mathrm{~K}$.

The total exposure time was 16.83 hours. The frames were integrated with the Bruker SAINT software package using a narrow-frame algorithm. The integration of the data using a monoclinicunit cell yielded a total of 27884 reflections to a maximum $\theta$ angle of $27.50^{\circ}$ ( $0.77 \AA$ resolution), of which 4564 were independent (average redundancy 6.110, completeness $=100.0 \%$, R int $=2.61 \%)$ and $4351(95.33 \%)$ were greater than $2 \sigma\left(\mathrm{F}^{2}\right)$. The final cell constants of $a=8.2364(5) \AA, b=21.5177(13) \AA, c=11.4389(7) \AA, \beta=101.7636(10)^{\circ}, V=1984.7(2) \AA^{3}$, are based upon the refinement of the XYZ-centroids of 9956 reflections above $20 \sigma(\mathrm{I})$ with $5.250^{\circ}<2 \theta<64.70^{\circ}$. Data were corrected for absorption effects using the multi-scan method (SADABS). The calculated minimum and maximum transmission coefficients (based on crystal size) are 0.1810 and 0.5300 . 
The structure was solved and refined using the Bruker SHELXTL Software Package, using the space group $\mathrm{P} 21 / \mathrm{n}$, with $\mathrm{Z}=4$ for the formula unit, $\mathrm{C}_{17} \mathrm{H}_{22} \mathrm{~N}_{2} \mathrm{O}{ }_{8} \mathrm{PtS}$. The final anisotropic fullmatrix least-squares refinement on $\mathrm{F}^{2}$ with 292 variables converged at $\mathrm{R}_{1}=4.00 \%$, for the observed data and $\mathrm{wR}_{2}=9.67 \%$ for all data. The goodness-of-fit was 1.461 . The largest peak in the final difference electron density synthesis was $1.843 \mathrm{e}^{-} / \AA^{3}$ and the largest hole was $-1.504 \mathrm{e}^{-}$ $/ \AA^{3}$ with an RMS deviation of $0.164 \mathrm{e}^{-} / \AA^{3}$. On the basis of the final model, the calculated density was $2.040 \mathrm{~g} / \mathrm{cm}^{3}$ and $\mathrm{F}(000), 1184 \mathrm{e}^{-}$.

APEX2 Version 2010.11-3 (Bruker AXS Inc.)

SAINT Version 7.68A (Bruker AXS Inc., 2009)

SADABS Version 2008/1 (G. M. Sheldrick, Bruker AXS Inc.)

XPREP Version 2008/2 (G. M. Sheldrick, Bruker AXS Inc.)

XS Version 2008/1 (G. M. Sheldrick, Acta Cryst. (2008). A64, 112-122)

XL Version 2012/4 (G. M. Sheldrick, (2012) University of Gottingen, Germany)

Platon (A. L. Spek, Acta Cryst. (1990). A46, C-34)

Table S10. Sample and crystal data for UM2653.

Identification code 2653

Chemical formula $\quad \mathrm{C}_{17} \mathrm{H}_{22} \mathrm{~N}_{2} \mathrm{O}_{8} \mathrm{PtS}$

Formula weight $\quad 609.51$

Temperature 100(2) K

Wavelength $\quad 0.71073 \AA$

Crystal size $\quad 0.09 \times 0.19 \times 0.49 \mathrm{~mm}$

Crystal habit yellow plate

Crystal system monoclinic

Space group $\quad \mathrm{P} 21 / \mathrm{n}$

$\begin{array}{lll}\text { Unit cell dimensions } & \begin{array}{l}\mathrm{a}=8.2364(5) \AA \\ \mathrm{b}=21.5177(13) \AA\end{array} & \begin{array}{l}\alpha=90^{\circ} \\ \beta=101.7636(10)^{\circ}\end{array}\end{array}$

$\mathrm{c}=11.4389(7) \AA \quad \gamma=90^{\circ}$

Volume $\quad 1984.7(2) \AA^{3}$

$\mathrm{Z} \quad 4$

Density (calculated) $\quad 2.040 \mathrm{Mg} / \mathrm{cm}^{3}$

Absorption coefficient $\quad 7.223 \mathrm{~mm}^{-1}$

F(000) 1184 
Table S11. Data collection and structure refinement for UM2653.

$\begin{array}{ll}\begin{array}{l}\text { Diffractometer } \\ \text { Radiation source }\end{array} & \begin{array}{l}\text { Bruker APEX-II CCD } \\ \text { sealed tube, MoK } \alpha\end{array} \\ \begin{array}{l}\text { Theta range for data } \\ \text { collection }\end{array} & 1.89 \text { to } 27.50^{\circ} \\ \begin{array}{l}\text { Index ranges } \\ \text { Reflections collected }\end{array} & -10 \leq \mathrm{h} \leq 10,-27 \leq \mathrm{k} \leq 27,-14 \leq 1 \leq 14 \\ \begin{array}{l}\text { Independent reflections } \\ \text { Coverage of }\end{array} & 4564[\mathrm{R}(\mathrm{int})=0.0261] \\ \begin{array}{l}\text { independent reflections } \\ \text { Absorption correction }\end{array} & 100.0 \% \\ \begin{array}{l}\text { Max. and min. } \\ \text { transmission }\end{array} & 0.5300 \text { and } 0.1810 \\ \begin{array}{l}\text { Structure solution } \\ \text { technique }\end{array} & \text { direct methods }\end{array}$

Structure solution

program

ShelXS-97 (Sheldrick, 2008)

Refinement method Full-matrix least-squares on $\mathrm{F}^{2}$

Refinement program ShelXL-2014 (Sheldrick, 2014)

Function minimized $\quad \Sigma \mathrm{w}\left(\mathrm{F}_{\mathrm{o}}{ }^{2}-\mathrm{F}_{\mathrm{c}}{ }^{2}\right)^{2}$

Data / restraints /

parameters

4564 / 49 / 292

Goodness-of-fit on $\mathbf{F}^{2}$

$\Delta / \sigma_{\max }$

0.001

Final $\mathbf{R}$ indices

4351 data; $\mathrm{I}>2 \sigma(\mathrm{I})$

$\mathrm{R}_{1}=0.0400, \mathrm{wR}_{2}=0.0961$

all data

$\mathrm{R}_{1}=0.0419, \mathrm{wR}_{2}=0.0967$

Weighting scheme

$\mathrm{w}=1 /\left[\sigma^{2}\left(\mathrm{Fo}_{\mathrm{o}}{ }^{2}\right)+(0.0100 \mathrm{P})^{2}+19.8600 \mathrm{P}\right], \mathrm{P}=\left(\mathrm{F}_{\mathrm{o}}{ }^{2}+2 \mathrm{~F}_{\mathrm{c}}{ }^{2}\right) / 3$

Largest diff. peak and hole

1.843 and $-1.504 \mathrm{e}^{-3}$

R.M.S. deviation from mean

$0.164 \mathrm{e}^{-3}$

$\mathrm{R}_{\text {int }}=\Sigma \mid F_{\mathrm{o}}^{2}-F_{\mathrm{o}}^{2}($ mean $) \mid / \Sigma\left[F_{\mathrm{o}}{ }^{2}\right]$

$\mathrm{R}_{1}=\Sigma|| F_{\mathrm{o}}|-| F_{\mathrm{c}} \| / \Sigma\left|F_{\mathrm{o}}\right|$

$\mathrm{GOOF}=\mathrm{S}=\left\{\Sigma\left[w\left(F_{\mathrm{o}}{ }^{2}-F_{\mathrm{c}}{ }^{2}\right)^{2}\right] /(\mathrm{n}-\mathrm{p})\right\}^{1 / 2}$

$w \mathrm{R}_{2}=\left\{\Sigma\left[w\left(F_{\mathrm{o}}{ }^{2}-F_{\mathrm{c}}{ }^{2}\right)^{2}\right] / \Sigma\left[w\left(F_{\mathrm{o}}{ }^{2}\right)^{2}\right]\right\}^{1 / 2}$ 
Table S12. Atomic coordinates and equivalent isotropic atomic displacement parameters $\left(\AA^{2}\right)$ for UM2653.

$\mathrm{U}(\mathrm{eq})$ is defined as one third of the trace of the orthogonalized $\mathrm{U}_{\mathrm{ij}}$ tensor.

\begin{tabular}{lllll} 
& \multicolumn{1}{c}{$\mathbf{x} / \mathbf{a}$} & \multicolumn{1}{c}{$\mathbf{y} / \mathbf{b}$} & \multicolumn{1}{c}{$\mathbf{z} / \mathbf{c}$} & \multicolumn{1}{c}{$\mathbf{U}(\mathbf{e q})$} \\
Pt1 & $0.50107(3)$ & $0.35831(2)$ & $0.09237(2)$ & $0.02165(9)$ \\
N1 & $0.3143(7)$ & $0.3726(3)$ & $0.1925(5)$ & $0.0246(12)$ \\
C1 & $0.1734(9)$ & $0.3385(4)$ & $0.1640(7)$ & $0.0280(16)$ \\
C2 & $0.0323(9)$ & $0.3517(4)$ & $0.2082(7)$ & $0.0321(17)$ \\
C3 & $0.0355(10)$ & $0.4011(4)$ & $0.2835(7)$ & $0.0358(19)$ \\
C4 & $0.1770(10)$ & $0.4369(4)$ & $0.3125(7)$ & $0.0326(17)$ \\
C5 & $0.3164(9)$ & $0.4215(4)$ & $0.2658(7)$ & $0.0261(15)$ \\
C6 & $0.4725(8)$ & $0.4604(3)$ & $0.3028(6)$ & $0.0235(14)$ \\
S1 & $0.6174(2)$ & $0.42126(8)$ & $0.42306(16)$ & $0.0243(4)$ \\
O11 & $0.6708(7)$ & $0.3648(3)$ & $0.3741(5)$ & $0.0335(12)$ \\
O12 & $0.7527(6)$ & $0.4656(3)$ & $0.4564(5)$ & $0.0282(11)$ \\
O13 & $0.5255(7)$ & $0.4111(3)$ & $0.5164(5)$ & $0.0330(12)$ \\
N7 & $0.5963(7)$ & $0.4428(3)$ & $0.1257(5)$ & $0.0217(12)$ \\
C7 & $0.5635(9)$ & $0.4823(3)$ & $0.2097(7)$ & $0.0259(15)$ \\
C8 & $0.6254(9)$ & $0.5426(4)$ & $0.2181(7)$ & $0.0305(17)$ \\
C9 & $0.7261(10)$ & $0.5625(4)$ & $0.1417(8)$ & $0.038(2)$ \\
C10 & $0.7646(9)$ & $0.5217(4)$ & $0.0595(7)$ & $0.0325(18)$ \\
C11 & $0.6996(8)$ & $0.4617(4)$ & $0.0506(7)$ & $0.0273(16)$ \\
C12 & $0.7285(9)$ & $0.4141(4)$ & $0.9672(7)$ & $0.0305(17)$ \\
C13 & $0.8234(10)$ & $0.4236(5)$ & $0.8789(8)$ & $0.041(2)$ \\
C14 & $0.8409(11)$ & $0.3770(5)$ & $0.8008(8)$ & $0.046(2)$ \\
C15 & $0.7629(11)$ & $0.3203(5)$ & $0.8082(8)$ & $0.043(2)$ \\
C16 & $0.6684(10)$ & $0.3103(4)$ & $0.8946(7)$ & $0.0362(18)$ \\
C17 & $0.6508(9)$ & $0.3564(4)$ & $0.9759(7)$ & $0.0282(15)$ \\
O1W & $0.4138(6)$ & $0.2700(2)$ & $0.0554(5)$ & $0.0246(10)$ \\
O2W & $0.1620(7)$ & $0.3073(3)$ & $0.6199(6)$ & $0.0369(13)$ \\
O3W & $0.4472(9)$ & $0.2843(3)$ & $0.5420(7)$ & $0.0468(16)$ \\
O4W & $0.0622(7)$ & $0.4262(3)$ & $0.5870(5)$ & $0.0336(12)$ \\
O5W & $0.6998(11)$ & $0.2400(3)$ & $0.3535(6)$ & $0.053(2)$ \\
& & & & \\
O)
\end{tabular}


Table S13. Bond lengths ( $(\AA)$ for UM2653.

$\begin{array}{llll}\text { Pt1-N7 } & 1.986(6) & \text { Pt1-C17 } & 1.992(7) \\ \text { Pt1-O1W } & 2.046(5) & \text { Pt1-N1 } & 2.120(6) \\ \text { N1-C5 } & 1.343(10) & \text { N1-C1 } & 1.356(9) \\ \text { C1-C2 } & 1.389(11) & \text { C1-H1 } & 0.95 \\ \text { C2-C3 } & 1.364(12) & \text { C2-H2 } & 0.95 \\ \text { C3-C4 } & 1.381(11) & \text { C3-H3 } & 0.95 \\ \text { C4-C5 } & 1.400(11) & \text { C4-H4 } & 0.95 \\ \text { C5-C6 } & 1.519(10) & \text { C6-C7 } & 1.498(11) \\ \text { C6-S1 } & 1.831(7) & \text { C6-H6 } & 1.0 \\ \text { S1-O11 } & 1.444(6) & \text { S1-O13 } & 1.446(6) \\ \text { S1-O12 } & 1.458(5) & \text { N7-C7 } & 1.351(10) \\ \text { N7-C11 } & 1.388(9) & \text { C7-C8 } & 1.390(10) \\ \text { C8-C9 } & 1.390(12) & \text { C8-H8 } & 0.95 \\ \text { C9-C10 } & 1.369(13) & \text { C9-H9 } & 0.95 \\ \text { C10-C11 } & 1.394(11) & \text { C10-H10 } & 0.95 \\ \text { C11-C12 } & 1.451(12) & \text { C12-C17 } & 1.410(11) \\ \text { C12-C13 } & 1.413(11) & \text { C13-C14 } & 1.369(14) \\ \text { C13-H13 } & 0.95 & \text { C14-C15 } & 1.389(14) \\ \text { C14-H14 } & 0.95 & \text { C15-C16 } & 1.394(12) \\ \text { C15-H15 } & 0.95 & \text { C16-C17 } & 1.388(12) \\ \text { C16-H16 } & 0.95 & \text { O1W-H11W } & 0.81(2) \\ \text { O1W-H12W } & 0.81(2) & \text { O2W-H21W } & 0.81(2) \\ \text { O2W-H22W } & 0.81(2) & \text { O3W-H31W } & 0.81(2) \\ \text { O3W-H32W } & 0.81(2) & \text { O4W-H41W } & 0.86(8) \\ \text { O4W-H42W } & 0.81(2) & \text { O5W-H51W } & 0.81(2) \\ \text { O5W-H52W } & 0.81(2) & & \end{array}$


Table S14. Bond angles $\left({ }^{\circ}\right)$ for UM2653.

$\begin{array}{llll}\text { N7-Pt1-C17 } & 82.7(3) & \text { N7-Pt1-O1W } & 177.1(2) \\ \text { C17-Pt1-O1W } & 94.7(3) & \text { N7-Pt1-N1 } & 93.7(2) \\ \text { C17-Pt1-N1 } & 168.8(3) & \text { O1W-Pt1-N1 } & 89.1(2) \\ \text { C5-N1-C1 } & 118.4(6) & \text { C5-N1-Pt1 } & 122.2(5) \\ \text { C1-N1-Pt1 } & 118.1(5) & \text { N1-C1-C2 } & 122.6(7) \\ \text { N1-C1-H1 } & 118.7 & \text { C2-C1-H1 } & 118.7 \\ \text { C3-C2-C1 } & 118.7(7) & \text { C3-C2-H2 } & 120.7 \\ \text { C1-C2-H2 } & 120.7 & \text { C2-C3-C4 } & 119.6(7) \\ \text { C2-C3-H3 } & 120.2 & \text { C4-C3-H3 } & 120.2 \\ \text { C3-C4-C5 } & 119.6(7) & \text { C3-C4-H4 } & 120.2 \\ \text { C5-C4-H4 } & 120.2 & \text { N1-C5-C4 } & 121.1(7) \\ \text { N1-C5-C6 } & 120.4(6) & \text { C4-C5-C6 } & 118.5(7) \\ \text { C7-C6-C5 } & 119.5(6) & \text { C7-C6-S1 } & 109.5(5) \\ \text { C5-C6-S1 } & 110.0(5) & \text { C7-C6-H6 } & 105.6 \\ \text { C5-C6-H6 } & 105.6 & \text { S1-C6-H6 } & 105.6 \\ \text { O11-S1-O13 } & 114.0(4) & \text { O11-S1-O12 } & 112.1(3) \\ \text { O13-S1-O12 } & 113.1(3) & \text { O11-S1-C6 } & 107.4(3) \\ \text { O13-S1-C6 } & 105.3(3) & \text { O12-S1-C6 } & 104.0(3) \\ \text { C7-N7-C11 } & 119.6(6) & \text { C7-N7-Pt1 } & 125.7(5) \\ \text { C11-N7-Pt1 } & 114.7(5) & \text { N7-C7-C8 } & 120.8(7) \\ \text { N7-C7-C6 } & 120.6(6) & \text { C8-C7-C6 } & 118.3(7) \\ \text { C7-C8-C9 } & 120.1(8) & \text { C7-C8-H8 } & 120.0 \\ \text { C9-C8-H8 } & 120.0 & \text { C10-C9-C8 } & 119.1(7) \\ \text { C10-C9-H9 } & 120.5 & \text { C8-C9-H9 } & 120.5 \\ \text { C9-C10-C11 } & 120.3(8) & \text { C9-C10-H10 } & 119.9 \\ \text { C11-C10-H10 } & 119.9 & \text { N7-C11-C10 } & 120.0(8) \\ \text { N7-C11-C12 } & 113.8(6) & \text { C10-C11-C12 } & 126.1(7) \\ \text { C17-C12-C13 } & 120.1(8) & \text { C17-C12-C11 } & 116.0(7) \\ \text { C13-C12-C11 } & 123.9(8) & \text { C14-C13-C12 } & 120.6(9) \\ \text { C14-C13-H13 } & 119.7 & \text { C12-C13-H13 } & 119.7 \\ \text { C13-C14-C15 } & 119.4(8) & \text { C13-C14-H14 } & 120.3 \\ \text { C15-C14-H14 } & 120.3 & \text { C14-C15-C16 } & 120.8(9) \\ \text { C14-C15-H15 } & 119.6 & \text { C16-C15-H15 } & 119.6 \\ \text { C17-C16-C15 } & 120.9(9) ~ & \text { C17-C16-H16 } & 119.5 \\ \text { C15-C16-H16 } & 119.5 & \text { C16-C17-C12 } & 118.2(7) \\ \text { C16-C17-Pt1 } & 128.8(6) ~ & \text { C12-C17-Pt1 } & 112.4(6) \\ \text { Pt1-O1W-H11W } & 117 .(6) & \text { Pt1-O1W-H12W } & 116 .(6)\end{array}$




$\begin{array}{llll}\text { H11W-O1W-H12W } & \text { 103.(5) } & \text { H21W-O2W-H22W } & \text { 102.(5) } \\ \text { H31W-O3W-H32W } & \text { 102.(5) } & \text { H41W-O4W-H42W } & \text { 98.(7) } \\ \text { H51W-O5W-H52W } & 102 .(5) & & \end{array}$

Table S15. Torsion angles $\left({ }^{\circ}\right)$ for UM2653.

$\begin{array}{llll}\text { C5-N1-C1-C2 } & -0.5(11) & \text { Pt1-N1-C1-C2 } & -167.9(6) \\ \text { N1-C1-C2-C3 } & -0.1(12) & \text { C1-C2-C3-C4 } & 0.9(13) \\ \text { C2-C3-C4-C5 } & -1.1(13) & \text { C1-N1-C5-C4 } & 0.3(11) \\ \text { Pt1-N1-C5-C4 } & 167.2(6) & \text { C1-N1-C5-C6 } & 178.5(7) \\ \text { Pt1-N1-C5-C6 } & -14.6(9) & \text { C3-C4-C5-N1 } & 0.5(12) \\ \text { C3-C4-C5-C6 } & -177.8(7) & \text { N1-C5-C6-C7 } & 47.9(10) \\ \text { C4-C5-C6-C7 } & -133.8(7) & \text { N1-C5-C6-S1 } & -80.0(8) \\ \text { C4-C5-C6-S1 } & 98.3(7) & \text { C7-C6-S1-O11 } & -67.3(6) \\ \text { C5-C6-S1-O11 } & 66.0(6) & \text { C7-C6-S1-O13 } & 170.8(5) \\ \text { C5-C6-S1-O13 } & -55.9(6) & \text { C7-C6-S1-O12 } & 51.6(6) \\ \text { C5-C6-S1-O12 } & -175.1(5) & \text { C11-N7-C7-C8 } & 3.2(10) \\ \text { Pt1-N7-C7-C8 } & -174.1(5) & \text { C11-N7-C7-C6 } & -171.4(6) \\ \text { Pt1-N7-C7-C6 } & 11.4(9) & \text { C5-C6-C7-N7 } & -46.6(9) \\ \text { S1-C6-C7-N7 } & 81.6(7) & \text { C5-C6-C7-C8 } & 138.8(7) \\ \text { S1-C6-C7-C8 } & -93.1(7) & \text { N7-C7-C8-C9 } & -1.8(11) \\ \text { C6-C7-C8-C9 } & 172.9(7) & \text { C7-C8-C9-C10 } & -0.7(11) \\ \text { C8-C9-C10-C11 } & 1.8(11) & \text { C7-N7-C11-C10 } & -2.1(10) \\ \text { Pt1-N7-C11-C10 } & 175.4(5) & \text { C7-N7-C11-C12 } & 178.1(6) \\ \text { Pt1-N7-C11-C12 } & -4.4(7) & \text { C9-C10-C11-N7 } & -0.4(11) \\ \text { C9-C10-C11-C12 } & 179.4(7) & \text { N7-C11-C12-C17 } & -0.9(9) \\ \text { C10-C11-C12-C17 } & 179.3(7) & \text { N7-C11-C12-C13 } & 177.1(7) \\ \text { C10-C11-C12-C13 } & -2.7(12) & \text { C17-C12-C13-C14 } & 0.1(12) \\ \text { C11-C12-C13-C14 } & -177.9(8) & \text { C12-C13-C14-C15 } & 0.7(13) \\ \text { C13-C14-C15-C16 } & -0.5(14) & \text { C14-C15-C16-C17 } & -0.5(14) \\ \text { C15-C16-C17-C12 } & 1.2(12) & \text { C15-C16-C17-Pt1 } & 171.0(7) \\ \text { C13-C12-C17-C16 } & -1.0(11) & \text { C11-C12-C17-C16 } & 177.1(7) \\ \text { C13-C12-C17-Pt1 } & -172.4(6) & \text { C11-C12-C17-Pt1 } & 5.7(8)\end{array}$




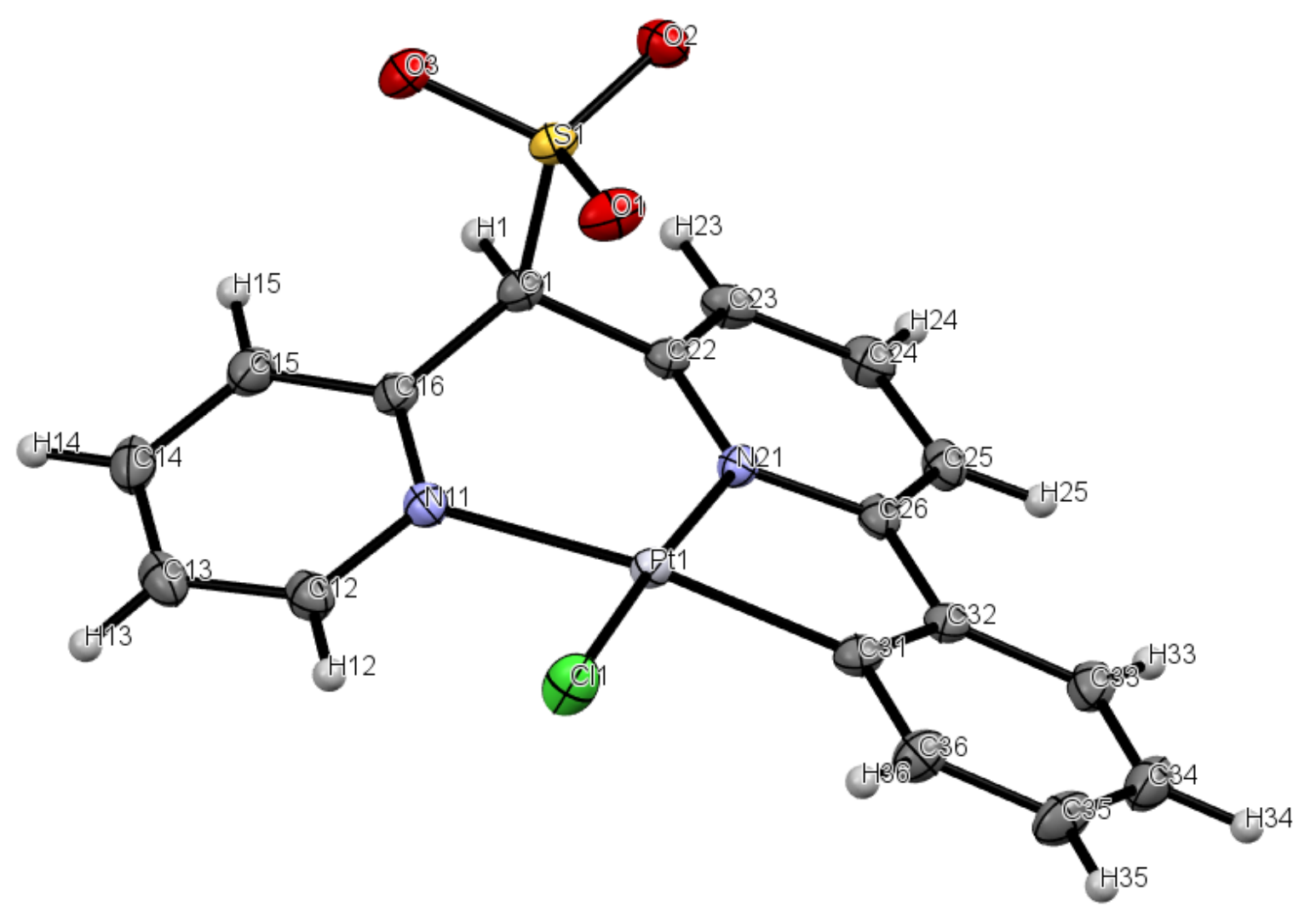

Figure S27. ORTEP plot for 9.

A yellow prism-like specimen of $\mathrm{C}_{18} \mathrm{H}_{20} \mathrm{ClKN}_{2} \mathrm{O}_{6} \mathrm{PtS}$, approximate dimensions $0.08 \mathrm{~mm}$ $\times 0.16 \mathrm{~mm} \times 0.20 \mathrm{~mm}$, was used for the X-ray crystallographic analysis. The X-ray intensity data were measured on a Bruker APEX-II CCD system equipped with a graphite monochromator and a MoK $\alpha$ sealed tube $(\lambda=0.71073 \AA)$. Data collection temperature was $150 \mathrm{~K}$.

The total exposure time was 12.63 hours. The frames were integrated with the Bruker SAINT software package using a narrow-frame algorithm. The integration of the data using a triclinic unit cell yielded a total of 35984 reflections to a maximum $\theta$ angle of $30.00^{\circ}(0.71 \AA$ resolution), of which 6049 were independent (average redundancy 5.949, completeness $=99.2 \%$, $\left.\mathrm{R}_{\text {int }}=4.23 \%\right)$ and $5706(94.33 \%)$ were greater than $2 \sigma\left(\mathrm{F}^{2}\right)$. The final cell constants of $a=8.3970(12) \AA, b=10.1882(15) \AA, c=13.2883(19) \AA, \alpha=101.511(2)^{\circ}, \beta=103.919(2)^{\circ}, \gamma$ $=101.654(2)^{\circ}, V=1043.2(3) \AA^{3}$, are based upon the refinement of the XYZ-centroids of 3490 reflections above $20 \sigma(\mathrm{I})$ with $5.180^{\circ}<2 \theta<62.76^{\circ}$. Data were corrected for absorption effects using the multi-scan method (SADABS). The calculated minimum and maximum transmission coefficients (based on crystal size) are 0.2770 and 0.5630 .

The structure was solved and refined using the Bruker SHELXTL Software Package, using the space group $\mathrm{P} \overline{1}$, with $\mathrm{Z}=2$ for the formula unit, $\mathrm{C}_{18} \mathrm{H}_{20} \mathrm{ClKN}_{2} \mathrm{O}_{6} \mathrm{PtS}$. The final anisotropic fullmatrix least-squares refinement on $\mathrm{F}^{2}$ with 304 variables converged at $\mathrm{R}_{1}=1.82 \%$, for the 
observed data and $\mathrm{wR}_{2}=4.10 \%$ for all data. The goodness-of-fit was 1.000 . The largest peak in the final difference electron density synthesis was $1.068 \mathrm{e}^{-} / \AA^{3}$ and the largest hole was $-1.171 \mathrm{e}^{-}$ $/ \AA^{3}$ with an RMS deviation of $0.109 \mathrm{e}^{-} / \AA^{3}$. On the basis of the final model, the calculated density was $2.108 \mathrm{~g} / \mathrm{cm}^{3}$ and $\mathrm{F}(000), 640 \mathrm{e}^{-}$.

APEX2 Version 2010.11-3 (Bruker AXS Inc.)

SAINT Version 7.68A (Bruker AXS Inc., 2009)

SADABS Version 2008/1 (G. M. Sheldrick, Bruker AXS Inc.)

XPREP Version 2008/2 (G. M. Sheldrick, Bruker AXS Inc.)

XS Version 2008/1 (G. M. Sheldrick, Acta Cryst. (2008). A64, 112-122)

XL Version 2012/4 (G. M. Sheldrick, (2012) University of Gottingen, Germany)

Platon (A. L. Spek, Acta Cryst. (1990). A46, C-34)

Table S16. Sample and crystal data for UM2562.

$\begin{array}{lll}\text { Identification code } & 2562 & \\ \text { Chemical formula } & \mathrm{C}_{18} \mathrm{H}_{20} \mathrm{ClKN}_{2} \mathrm{O}_{6} \mathrm{PtS} & \\ \text { Formula weight } & 662.06 & \\ \text { Temperature } & 150(2) \mathrm{K} & \\ \text { Wavelength } & 0.71073 \AA & \\ \text { Crystal size } & 0.08 \times 0.16 \times 0.20 \mathrm{~mm} & \\ \text { Crystal habit } & \text { yellow prism } & \\ \text { Crystal system } & \text { triclinic } & \\ \text { Space group } & \mathrm{P} \overline{1} & \alpha=101.511(2)^{\circ} \\ \text { Unit cell dimensions } & \mathrm{a}=8.3970(12) \AA & \beta=103.919(2)^{\circ} \\ & \mathrm{b}=10.1882(15) \AA & \gamma=101.654(2)^{\circ} \\ & \mathrm{c}=13.2883(19) \AA & \\ \text { Volume } & 1043.2(3) \AA^{3} & \\ Z & 2 & \\ \text { Density (calculated) } & 2.108 \mathrm{Mg}^{3} \mathrm{~cm}^{3} & \\ \text { Absorption coefficient } & 7.192 \mathrm{~mm}^{-1} & \\ \text { F(000) } & 640\end{array}$


Table S17. Data collection and structure refinement for UM2562.

$\begin{array}{ll}\begin{array}{l}\text { Diffractometer } \\ \text { Radiation source }\end{array} & \begin{array}{l}\text { Bruker APEX-II CCD } \\ \text { sealed tube, MoK } \alpha\end{array} \\ \begin{array}{l}\text { Theta range for data } \\ \text { collection }\end{array} & 2.11 \text { to } 30.00^{\circ} \\ \begin{array}{l}\text { Reflections collected } \\ \text { Independent reflections } \\ \text { Coverage of independent } \\ \text { reflections }\end{array} & 65984 \\ & 99.2 \%\end{array}$

Absorption correction multi-scan

Max. and min.

transmission

0.5630 and 0.2770

Structure solution technique

direct methods

Structure solution

program

ShelXS-97 (Sheldrick, 2008)

Refinement method

Full-matrix least-squares on $\mathrm{F}^{2}$

Refinement program

ShelXL-2012 (Sheldrick, 2012)

Function minimized $\quad \Sigma \mathrm{w}\left(\mathrm{F}_{\mathrm{o}}{ }^{2}-\mathrm{F}_{\mathrm{c}}{ }^{2}\right)^{2}$

Data / restraints /

parameters

$6049 / 11 / 304$

Goodness-of-fit on $\mathbf{F}^{2} \quad 1.000$

Final $\mathbf{R}$ indices

5706 data; $\mathrm{I}>2 \sigma(\mathrm{I}) \quad \begin{aligned} & \mathrm{R}_{1}=0.0182, \mathrm{wR}_{2}= \\ & 0.0406\end{aligned}$

all data

$\mathrm{R}_{1}=0.0198, \mathrm{wR}_{2}=$

$\mathrm{W}=1 /\left[\sigma^{2}\left(\mathrm{~F}_{\mathrm{o}}^{2}\right)+(0.0100 \mathrm{P})^{2}+0.0135 \mathrm{P}\right]$,

Weighting scheme

$\mathrm{P}=\left(\mathrm{F}_{\mathrm{o}}{ }^{2}+2 \mathrm{~F}_{\mathrm{c}}{ }^{2}\right) / 3$

Largest diff. peak and

hole

1.068 and $-1.171 \mathrm{e}^{-3}$

R.M.S. deviation from mean

$0.109 \mathrm{e}^{-3}$

$\mathrm{R}_{\text {int }}=\Sigma \mid F_{\mathrm{o}}{ }^{2}-F_{\mathrm{o}}^{2}($ mean $) \mid / \Sigma\left[F_{\mathrm{o}}{ }^{2}\right]$

$\mathrm{R}_{1}=\Sigma|| F_{\mathrm{o}}|-| F_{\mathrm{c}}|/ \Sigma| F_{\mathrm{o}} \mid$

$\mathrm{GOOF}=\mathrm{S}=\left\{\Sigma\left[w\left(F_{\mathrm{o}}{ }^{2}-F_{\mathrm{c}}{ }^{2}\right)^{2}\right] /(\mathrm{n}-\mathrm{p})\right\}^{1 / 2}$

$w \mathrm{R}_{2}=\left\{\Sigma\left[w\left(F_{\mathrm{o}}{ }^{2}-F_{\mathrm{c}}\right)^{2}\right] / \Sigma\left[w\left(F_{\mathrm{o}}\right)^{2}\right]\right\}^{1 / 2}$ 
Table S18. Atomic coordinates and equivalent isotropic atomic displacement parameters $\left(\AA^{2}\right)$ for UM2562.

$\mathrm{U}(\mathrm{eq})$ is defined as one third of the trace of the orthogonalized $\mathrm{U}_{\mathrm{ij}}$ tensor.

\begin{tabular}{lllll} 
& \multicolumn{1}{c}{$\mathbf{x} / \mathbf{a}$} & \multicolumn{1}{c}{$\mathbf{y} / \mathbf{b}$} & \multicolumn{1}{c}{$\mathbf{z} / \mathbf{c}$} & \multicolumn{1}{c}{$\mathbf{U}(\mathbf{e q})$} \\
$\mathrm{Pt1}$ & $0.44062(2)$ & $0.24668(2)$ & $0.33299(2)$ & $0.01422(3)$ \\
$\mathrm{C} 11$ & $0.48809(8)$ & $0.03133(6)$ & $0.33378(5)$ & $0.02709(13)$ \\
$\mathrm{C} 1$ & $0.4918(3)$ & $0.4613(2)$ & $0.18034(16)$ & $0.0158(4)$ \\
$\mathrm{S} 1$ & $0.32503(7)$ & $0.34838(6)$ & $0.06048(4)$ & $0.01618(10)$ \\
$\mathrm{O} 1$ & $0.2571(2)$ & $0.22034(18)$ & $0.08482(13)$ & $0.0246(4)$ \\
$\mathrm{O} 2$ & $0.2013(2)$ & $0.42925(18)$ & $0.04025(13)$ & $0.0222(3)$ \\
$\mathrm{O} 3$ & $0.4117(2)$ & $0.33036(18)$ & $0.97768(12)$ & $0.0224(4)$ \\
$\mathrm{N} 11$ & $0.6332(2)$ & $0.2976(2)$ & $0.25697(14)$ & $0.0167(4)$ \\
$\mathrm{C} 12$ & $0.7700(3)$ & $0.2450(3)$ & $0.27768(18)$ & $0.0210(5)$ \\
$\mathrm{C} 13$ & $0.9141(3)$ & $0.2909(3)$ & $0.24763(19)$ & $0.0239(5)$ \\
$\mathrm{C} 14$ & $0.9208(3)$ & $0.3943(3)$ & $0.19414(19)$ & $0.0247(5)$ \\
$\mathrm{C} 15$ & $0.7817(3)$ & $0.4492(3)$ & $0.17297(18)$ & $0.0218(5)$ \\
$\mathrm{C} 16$ & $0.6403(3)$ & $0.3993(2)$ & $0.20526(17)$ & $0.0168(4)$ \\
$\mathrm{N} 21$ & $0.3813(2)$ & $0.42754(19)$ & $0.33374(14)$ & $0.0145(4)$ \\
$\mathrm{C} 22$ & $0.4194(3)$ & $0.5114(2)$ & $0.27034(16)$ & $0.0149(4)$ \\
$\mathrm{C} 23$ & $0.3897(3)$ & $0.6411(2)$ & $0.28475(18)$ & $0.0186(4)$ \\
$\mathrm{C} 24$ & $0.3140(3)$ & $0.6860(3)$ & $0.36334(18)$ & $0.0206(5)$ \\
$\mathrm{C} 25$ & $0.2670(3)$ & $0.5982(2)$ & $0.42359(17)$ & $0.0189(4)$ \\
$\mathrm{C} 26$ & $0.2998(3)$ & $0.4689(2)$ & $0.40853(16)$ & $0.0158(4)$ \\
$\mathrm{C} 31$ & $0.2983(3)$ & $0.2380(2)$ & $0.43261(17)$ & $0.0175(4)$ \\
$\mathrm{C} 32$ & $0.2534(3)$ & $0.3627(2)$ & $0.46399(16)$ & $0.0164(4)$ \\
$\mathrm{C} 33$ & $0.1665(3)$ & $0.3809(3)$ & $0.54177(18)$ & $0.0210(5)$ \\
$\mathrm{C} 34$ & $0.1241(3)$ & $0.2746(3)$ & $0.58922(19)$ & $0.0253(5)$ \\
$\mathrm{C} 35$ & $0.1697(3)$ & $0.1520(3)$ & $0.56008(19)$ & $0.0263(5)$ \\
$\mathrm{C} 36$ & $0.2556(3)$ & $0.1333(3)$ & $0.48348(18)$ & $0.0229(5)$ \\
$\mathrm{O} 4$ & $0.0515(2)$ & $0.0135(2)$ & $0.15048(15)$ & $0.0294(4)$ \\
$\mathrm{C} 41$ & $0.0051(4)$ & $0.9259(3)$ & $0.2151(2)$ & $0.0363(7)$ \\
$\mathrm{K} 1$ & $0.22381(7)$ & $0.94394(6)$ & $0.99890(4)$ & $0.02752(12)$ \\
$\mathrm{O} 1 \mathrm{~W}$ & $0.4443(3)$ & $0.0642(2)$ & $0.89641(15)$ & $0.0314(4)$ \\
$\mathrm{O} 2 \mathrm{~W}$ & $0.1514(3)$ & $0.7058(2)$ & $0.06189(16)$ & $0.0330(4)$
\end{tabular}


Table S19. Bond lengths ( $(\AA)$ for UM2562.

$\begin{array}{llll}\text { Pt1-C31 } & 1.988(2) & \text { Pt1-N21 } & 2.0023(19) \\ \text { Pt1-N11 } & 2.1357(18) & \text { Pt1-C11 } & 2.3094(7) \\ \text { C1-C16 } & 1.505(3) & \text { C1-C22 } & 1.514(3) \\ \text { C1-S1 } & 1.835(2) & \text { C1-H1 } & 1.0 \\ \text { S1-O1 } & 1.4450(18) & \text { S1-O2 } & 1.4598(17) \\ \text { S1-O3 } & 1.4600(16) & \text { O1-K1 } & 2.7490(19) \\ \text { N11-C16 } & 1.353(3) & \text { N11-C12 } & 1.355(3) \\ \text { C12-C13 } & 1.386(3) & \text { C12-H12 } & 0.95 \\ \text { C13-C14 } & 1.383(4) & \text { C13-H13 } & 0.95 \\ \text { C14-C15 } & 1.388(3) & \text { C14-H14 } & 0.95 \\ \text { C15-C16 } & 1.393(3) & \text { C15-H15 } & 0.95 \\ \text { N21-C22 } & 1.359(3) & \text { N21-C26 } & 1.382(3) \\ \text { C22-C23 } & 1.379(3) & \text { C23-C24 } & 1.397(3) \\ \text { C23-H23 } & 0.95 & \text { C24-C25 } & 1.376(3) \\ \text { C24-H24 } & 0.95 & \text { C25-C26 } & 1.385(3) \\ \text { C25-H25 } & 0.95 & \text { C26-C32 } & 1.467(3) \\ \text { C31-C36 } & 1.405(3) & \text { C31-C32 } & 1.410(3) \\ \text { C32-C33 } & 1.405(3) & \text { C33-C34 } & 1.387(3) \\ \text { C33-H33 } & 0.95 & \text { C34-C35 } & 1.388(4) \\ \text { C34-H34 } & 0.95 & \text { C35-C36 } & 1.388(3) \\ \text { C35-H35 } & 0.95 & \text { C36-H36 } & 0.95 \\ \text { O4-C41 } & 1.419(3) & \text { O4-K1 } & 2.8102(19) \\ \text { O4-K1 } & 2.831(2) & \text { O4-H4 } & 0.847(17) \\ \text { C41-H41A } & 0.98 & \text { C41-H41B } & 0.98 \\ \text { C41-H41C } & 0.98 & \text { K1-O2W } & 2.723(2) \\ \text { K1-O1 } & 2.7490(19) & \text { K1-O1W } & 2.783(2) \\ \text { K1-O4 } & 2.8102(19) & \text { K1-O1W } & 2.825(2) \\ \text { K1-O4 } & 2.831(2) & \text { O1W-K1 } & 2.783(2) \\ \text { O1W-K1 } & 2.825(2) & \text { O1W-H11W } & 0.854(16) \\ \text { O1W-H12W } & 0.852(16) & \text { O2W-K1 } & 2.723(2) \\ \text { O2W-H21W } & 0.848(16) & \text { O2W-H22W } & 0.848(16) \\ & & & \end{array}$


Table S20. Bond angles $\left({ }^{\circ}\right)$ for UM2562.

$\begin{array}{llll}\text { C31-Pt1-N21 } & 81.96(8) & \text { C31-Pt1-N11 } & 166.08(8) \\ \text { N21-Pt1-N11 } & 92.20(7) & \text { C31-Pt1-C11 } & 94.19(7) \\ \text { N21-Pt1-C11 } & 175.44(5) & \text { N11-Pt1-C11 } & 92.09(5) \\ \text { C16-C1-C22 } & 118.39(18) & \text { C16-C1-S1 } & 110.59(15) \\ \text { C22-C1-S1 } & 111.78(15) & \text { C16-C1-H1 } & 104.9 \\ \text { C22-C1-H1 } & 104.9 & \text { S1-C1-H1 } & 104.9 \\ \text { O1-S1-O2 } & 113.09(11) & \text { O1-S1-O3 } & 113.54(10) \\ \text { O2-S1-O3 } & 112.86(10) & \text { O1-S1-C1 } & 108.31(10) \\ \text { O2-S1-C1 } & 103.79(10) & \text { O3-S1-C1 } & 104.25(10) \\ \text { S1-O1-K1 } & 135.13(10) & \text { C16-N11-C12 } & 117.78(19) \\ \text { C16-N11-Pt1 } & 122.33(14) & \text { C12-N11-Pt1 } & 118.74(16) \\ \text { N11-C12-C13 } & 122.7(2) & \text { N11-C12-H12 } & 118.7 \\ \text { C13-C12-H12 } & 118.7 & \text { C14-C13-C12 } & 119.5(2) \\ \text { C14-C13-H13 } & 120.3 & \text { C12-C13-H13 } & 120.3 \\ \text { C13-C14-C15 } & 118.3(2) & \text { C13-C14-H14 } & 120.9 \\ \text { C15-C14-H14 } & 120.9 & \text { C14-C15-C16 } & 119.8(2) \\ \text { C14-C15-H15 } & 120.1 & \text { C16-C15-H15 } & 120.1 \\ \text { N11-C16-C15 } & 122.0(2) & \text { N11-C16-C1 } & 119.91(19) \\ \text { C15-C16-C1 } & 118.1(2) & \text { C22-N21-C26 } & 119.28(19) \\ \text { C22-N21-Pt1 } & 125.47(14) & \text { C26-N21-Pt1 } & 115.21(15) \\ \text { N21-C22-C23 } & 121.15(19) & \text { N21-C22-C1 } & 119.96(19) \\ \text { C23-C22-C1 } & 118.87(19) & \text { C22-C23-C24 } & 119.8(2) \\ \text { C22-C23-H23 } & 120.1 & \text { C24-C23-H23 } & 120.1 \\ \text { C25-C24-C23 } & 119.1(2) & \text { C25-C24-H24 } & 120.5 \\ \text { C23-C24-H24 } & 120.5 & \text { C24-C25-C26 } & 120.2(2) \\ \text { C24-C25-H25 } & 119.9 & \text { C26-C25-H25 } & 119.9 \\ \text { N21-C26-C25 } & 120.4(2) & \text { N21-C26-C32 } & 113.05(19) \\ \text { C25-C26-C32 } & 126.54(19) & \text { C36-C31-C32 } & 117.4(2) \\ \text { C36-C31-Pt1 } & 128.95(18) & \text { C32-C31-Pt1 } & 113.17(16) \\ \text { C33-C32-C31 } & 121.4(2) & \text { C33-C32-C26 } & 123.0(2) \\ \text { C31-C32-C26 } & 115.58(18) & \text { C34-C33-C32 } & 119.6(2) \\ \text { C34-C33-H33 } & 120.2 & \text { C32-C33-H33 } & 120.2 \\ \text { C33-C34-C35 } & 119.5(2) & \text { C33-C34-H34 } & 120.2 \\ \text { C35-C34-H34 } & 120.2 & \text { C36-C35-C34 } & 121.2(2) \\ \text { C36-C35-H35 } & 119.4 & \text { C34-C35-H35 } & 119.4 \\ \text { C35-C36-C31 } & 120.8(2) & \text { C35-C36-H36 } & 119.6 \\ \text { C31-C36-H36 } & 119.6 & \text { C41-O4-K1 } & 123.21(17) \\ & & & \end{array}$




$\begin{array}{llll}\text { C41-O4-K1 } & 115.18(16) & \text { K1-O4-K1 } & 94.67(6) \\ \text { C41-O4-H4 } & 108 .(3) & \text { K1-O4-H4 } & 80 .(3) \\ \text { K1-O4-H4 } & 131 .(3) & \text { O4-C41-H41A } & 109.5 \\ \text { O4-C41-H41B } & 109.5 & \text { H41A-C41-H41B } & 109.5 \\ \text { O4-C41-H41C } & 109.5 & \text { H41A-C41-H41C } & 109.5 \\ \text { H41B-C41-H41C } & 109.5 & \text { O2W-K1-O1 } & 135.84(6) \\ \text { O2W-K1-O1W } & 137.81(6) & \text { O1-K1-O1W } & 79.76(6) \\ \text { O2W-K1-O4 } & 77.42(6) & \text { O1-K1-O4 } & 61.88(6) \\ \text { O1W-K1-O4 } & 141.62(6) & \text { O2W-K1-O1W } & 79.84(6) \\ \text { O1-K1-O1W } & 97.90(6) & \text { O1W-K1-O1W } & 71.95(7) \\ \text { O4-K1-O1W } & 110.19(6) & \text { O2W-K1-O4 } & 114.91(6) \\ \text { O1-K1-O4 } & 79.75(6) & \text { O1W-K1-O4 } & 89.32(6) \\ \text { O4-K1-O4 } & 85.33(6) & \text { O1W-K1-O4 } & 161.21(6) \\ \text { K1-O1W-K1 } & 108.04(7) & \text { K1-O1W-H11W } & 103 .(2) \\ \text { K1-O1W-H11W } & 108 .(2) & \text { K1-O1W-H12W } & 139 .(2) \\ \text { K1-O1W-H12W } & 97 .(2) & \text { H11W-O1W-H12W } & 99 .(2) \\ \text { K1-O2W-H21W } & 142 .(2) & \text { K1-O2W-H22W } & 106 .(2) \\ \text { H21W-O2W-H22W } & 101 .(3) & & \end{array}$


Table S21. Torsion angles $\left({ }^{\circ}\right)$ for UM2562.

$\begin{array}{llll}\text { C16-C1-S1-O1 } & 65.84(17) & \text { C22-C1-S1-O1 } & -68.35(18) \\ \text { C16-C1-S1-O2 } & -173.73(15) & \text { C22-C1-S1-O2 } & 52.08(17) \\ \text { C16-C1-S1-O3 } & -55.36(17) & \text { C22-C1-S1-O3 } & 170.45(15) \\ \text { O2-S1-O1-K1 } & 123.01(13) & \text { O3-S1-O1-K1 } & -7.26(18) \\ \text { C1-S1-O1-K1 } & -122.53(13) & \text { C16-N11-C12-C13 } & -0.3(3) \\ \text { Pt1-N11-C12-C13 } & -168.41(17) & \text { N11-C12-C13-C14 } & -0.1(4) \\ \text { C12-C13-C14-C15 } & 0.4(3) & \text { C13-C14-C15-C16 } & -0.2(3) \\ \text { C12-N11-C16-C15 } & 0.5(3) & \text { Pt1-N11-C16-C15 } & 168.09(16) \\ \text { C12-N11-C16-C1 } & -179.97(19) & \text { Pt1-N11-C16-C1 } & -12.3(3) \\ \text { C14-C15-C16-N11 } & -0.2(3) & \text { C14-C15-C16-C1 } & -179.8(2) \\ \text { C22-C1-C16-N11 } & 50.7(3) & \text { S1-C1-C16-N11 } & -80.1(2) \\ \text { C22-C1-C16-C15 } & -129.7(2) & \text { S1-C1-C16-C15 } & 99.5(2) \\ \text { C26-N21-C22-C23 } & 4.9(3) & \text { Pt1-N21-C22-C23 } & -172.85(16) \\ \text { C26-N21-C22-C1 } & -173.62(19) & \text { Pt1-N21-C22-C1 } & 8.6(3) \\ \text { C16-C1-C22-N21 } & -49.4(3) & \text { S1-C1-C22-N21 } & 80.9(2) \\ \text { C16-C1-C22-C23 } & 132.1(2) & \text { S1-C1-C22-C23 } & -97.7(2) \\ \text { N21-C22-C23-C24 } & -2.2(3) & \text { C1-C22-C23-C24 } & 176.4(2) \\ \text { C22-C23-C24-C25 } & -1.4(3) & \text { C23-C24-C25-C26 } & 2.1(3) \\ \text { C22-N21-C26-C25 } & -4.1(3) & \text { Pt1-N21-C26-C25 } & 173.84(16) \\ \text { C22-N21-C26-C32 } & 174.77(18) & \text { Pt1-N21-C26-C32 } & -7.3(2) \\ \text { C24-C25-C26-N21 } & 0.6(3) & \text { C24-C25-C26-C32 } & -178.1(2) \\ \text { C36-C31-C32-C33 } & -1.1(3) & \text { Pt1-C31-C32-C33 } & -174.02(17) \\ \text { C36-C31-C32-C26 } & -179.8(2) & \text { Pt1-C31-C32-C26 } & 7.3(2) \\ \text { N21-C26-C32-C33 } & -178.7(2) & \text { C25-C26-C32-C33 } & 0.1(4) \\ \text { N21-C26-C32-C31 } & -0.1(3) & \text { C25-C26-C32-C31 } & 178.8(2) \\ \text { C31-C32-C33-C34 } & 0.2(3) & \text { C26-C32-C33-C34 } & 178.7(2) \\ \text { C32-C33-C34-C35 } & 0.7(4) & \text { C33-C34-C35-C36 } & -0.6(4) \\ \text { C34-C35-C36-C31 } & -0.4(4) & \text { C32-C31-C36-C35 } & 1.2(4) \\ \text { Pt1-C31-C36-C35 } & 172.83(19) & & \end{array}$




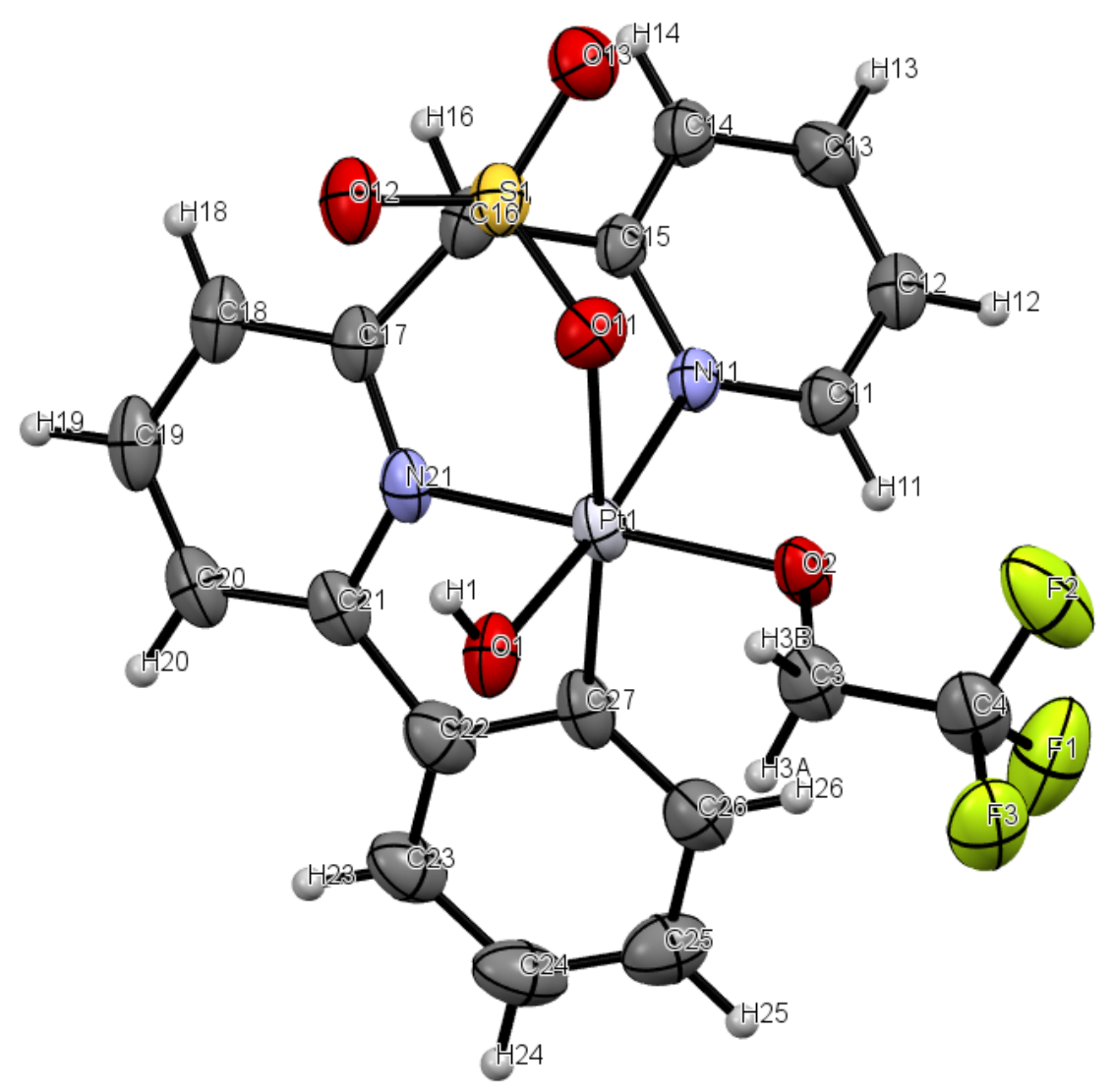

Figure S28. ORTEP plot for 15.

\section{Experimental:}

A suitable single crystals of $\mathrm{C}_{21.83} \mathrm{H}_{20.91} \mathrm{~F}_{4.75} \mathrm{~N}_{2} \mathrm{O}_{6} \mathrm{PtS}$ (UM2783) was selected and measured on a Bruker Smart Apex II CCD diffractometer [1]. The crystal was kept at 150(2) K during data collection. The integral intensity were correct for absorption using SADABS software [2] using multi-scan method. Resulting minimum and maximum transmission are 0.603 and 0.917 respectively. The structure was solved with the ShelXT program and refined with the XL program and Least Squares minimisation using ShelX software package [3]. Number of restraints used $=$ 53 , number of constraints - unknown.

\section{Crystal structure determination:}

Crystal Data for $\mathrm{C}_{21.83} \mathrm{H}_{20.91} \mathrm{~F}_{4.75} \mathrm{~N}_{2} \mathrm{O}_{6} \mathrm{PtS}(M=724.73 \mathrm{~g} / \mathrm{mol})$ : monoclinic, space group $\mathrm{C} 2 / \mathrm{c}$ (no. 15), $a=16.6874(16) \AA, b=23.394(2) \AA, c=15.0493(14) \AA, \beta=121.7150(10)^{\circ}, V=$ 4997.7(8) $\AA^{3}, Z=8, T=150(2) \mathrm{K}, \mu(\mathrm{MoK} \alpha)=5.775 \mathrm{~mm}^{-1}$, Dcalc $=1.926 \mathrm{~g} / \mathrm{cm}^{3}, 24548$ reflections measured $\left(3.356^{\circ} \leq 2 \Theta \leq 52.994^{\circ}\right), 5177$ unique $\left(R_{\text {int }}=0.0644, R_{\text {sig }}=0.0389\right)$ which were used in all calculations. The final $R_{1}$ was 0.0371 (I $\left.>2 \sigma(\mathrm{I})\right)$ and $w R_{2}$ was 0.0979 (all data).

\section{Refinement details:}


Refined as 2-component non-merohedral twin with components ratio of 3:1. H atoms were positioned from geometric consideration and refined as riding on the attached atom with Uiso constrained to be $20 \%$ larger (50\% for methyl groups) than Ueqv of the attached atom with exception of $\mathrm{H}$-bonded $\mathrm{H}$ atoms for which Uiso was freely refined. The structure contained 2 different solvent molecules $\mathrm{CF} 3 \mathrm{CH} 2 \mathrm{OH}$ and $\mathrm{CH} 3 \mathrm{CH} 2 \mathrm{OCH} 2 \mathrm{CH} 3$ which are disordered to occupy the same space in about 3:2 ration. Their some geometric parameters were restrained to be similar and atomic displacement parameters to correspond to rigid body motions.

\section{References:}

1. Bruker (2010). Apex2. Bruker AXS Inc., Madison, Wisconsin, USA.

2. Sheldrick, G. M. (2008), Acta Cryst. A64, 112-122.

3. Sheldrick, G. M. (2014). SHELXL-2014. University of Gottingen, Germany.

4. Dolomanov, O.V., Bourhis, L.J., Gildea, R.J, Howard, J.A.K. \& Puschmann, H. (2009), J. Appl. Cryst. 42, 339-341. 
Table S22. Sample and crystal data for UM2783

Identification code

Empirical formula

Formula weight

Temperature/K

$\mathrm{C}_{21.83} \mathrm{H}_{20.91} \mathrm{~F}_{4.75} \mathrm{~N}_{2} \mathrm{O}_{6} \mathrm{PtS}$

Crystal system

Space group

$\mathrm{a} / \AA$

$\mathrm{b} / \AA$

$\mathrm{c} / \AA$

$\alpha /{ }^{\circ}$

$\beta /{ }^{\circ}$

$\gamma /{ }^{\circ}$

Volume $/ \AA^{3}$

Z

$\rho_{\text {calcg }} / \mathrm{cm}^{3}$

$\mu / \mathrm{mm}^{-1}$

$\mathrm{F}(000)$

Crystal size $/ \mathrm{mm}^{3}$

Radiation

$2 \Theta$ range for data collection/ ${ }^{\circ}$

Index ranges

Reflections collected

Independent reflections

Data/restraints/parameters

Goodness-of-fit on $\mathrm{F}^{2}$

Final R indexes $[\mathrm{I}>=2 \sigma(\mathrm{I})]$

Final $\mathrm{R}$ indexes [all data]

Largest diff. peak/hole / e $\AA^{-3}$

724.73

150(2)

monoclinic

$\mathrm{C} 2 / \mathrm{c}$

16.6874(16)

23.394(2)

15.0493(14)

90

$121.7150(10)$

90

4997.7(8)

8

1.926

5.775

2805.0

$0.44 \times 0.03 \times 0.015$

$\operatorname{MoK} \alpha(\lambda=0.71073)$

3.356 to 52.994

$-20 \leq \mathrm{h} \leq 17,0 \leq \mathrm{k} \leq 29,0 \leq 1 \leq 18$ 24548

$5177\left[R_{\text {int }}=0.0644, R_{\text {sigma }}=0.0389\right]$

$5177 / 53 / 383$

1.088

$\mathrm{R}_{1}=0.0371, \mathrm{wR}_{2}=0.0926$

$\mathrm{R}_{1}=0.0514, \mathrm{wR}_{2}=0.0979$

$2.18 /-1.54$ 
Table S23. Fractional Atomic Coordinates and Equivalent Isotropic Displacement Parameters $\left(\AA^{2}\right)$ for $\mathrm{UM} 2783$. $\mathrm{U}_{\text {eq }}$ is defined as $1 / 3$ of of the trace of the orthogonalised $\mathrm{U}_{\mathrm{IJ}}$ tensor.

\begin{tabular}{|c|c|c|c|c|}
\hline Atom & $x$ & $y$ & $\mathbf{Z}$ & $\mathbf{U}(\mathbf{e q}$ \\
\hline Pt1 & $0.45920(2)$ & $0.20942(2)$ & $0.45564(2)$ & $0.03128(9)$ \\
\hline $\mathrm{O} 1$ & $0.3615(3)$ & $0.2464(2)$ & $0.4828(3)$ & $0.0395(10)$ \\
\hline $\mathrm{O} 2$ & $0.4020(3)$ & $0.24472(18)$ & $0.3144(3)$ & $0.0353(10)$ \\
\hline $\mathrm{C} 3$ & $0.3321(5)$ & $0.2865(3)$ & $0.2871(5)$ & $0.0409(15)$ \\
\hline $\mathrm{C} 4$ & $0.3090(5)$ & $0.3128(3)$ & $0.1864(6)$ & $0.0486(17)$ \\
\hline $\mathrm{F} 1$ & $0.3841(3)$ & $0.3355(2)$ & $0.1905(4)$ & $0.0806(16)$ \\
\hline $\mathrm{F} 2$ & $0.2715(4)$ & $0.2768(2)$ & $0.1067(3)$ & $0.0828(17)$ \\
\hline F3 & $0.2463(3)$ & $0.35502(19)$ & $0.1599(3)$ & $0.0628(12)$ \\
\hline O11 & $0.3622(3)$ & $0.13704(18)$ & $0.3796(3)$ & $0.0377(10)$ \\
\hline $\mathrm{O} 12$ & $0.3530(3)$ & $0.0661(2)$ & $0.4931(3)$ & $0.0438(11)$ \\
\hline $\mathrm{C} 13$ & $0.6510(5)$ & $0.0926(3)$ & $0.3772(5)$ & $0.0398(15)$ \\
\hline $\mathrm{S} 1$ & $0.39047(11)$ & $0.07958(7)$ & $0.42824(12)$ & $0.0357(3)$ \\
\hline N11 & $0.5485(3)$ & $0.1636(2)$ & $0.4291(3)$ & $0.0287(10)$ \\
\hline $\mathrm{C} 11$ & $0.5859(4)$ & $0.1838(3)$ & $0.3755(4)$ & $0.0337(13)$ \\
\hline $\mathrm{C} 12$ & $0.6370(4)$ & $0.1498(3)$ & $0.3483(5)$ & $0.0374(14)$ \\
\hline $\mathrm{O} 13$ & $0.3771(3)$ & $0.0371(2)$ & $0.3530(3)$ & $0.0441(11)$ \\
\hline $\mathrm{C} 14$ & $0.6134(4)$ & $0.0717(3)$ & $0.4344(5)$ & $0.0352(14)$ \\
\hline C15 & $0.5624(4)$ & $0.1074(3)$ & $0.4594(4)$ & $0.0287(12)$ \\
\hline $\mathrm{C} 16$ & $0.5182(4)$ & $0.0847(3)$ & $0.5186(5)$ & $0.0345(14)$ \\
\hline $\mathrm{C} 17$ & $0.5441(4)$ & $0.1190(3)$ & $0.6143(4)$ & $0.0332(13)$ \\
\hline $\mathrm{C} 18$ & $0.5875(4)$ & $0.0970(3)$ & $0.7143(5)$ & $0.0390(15)$ \\
\hline C19 & $0.6205(4)$ & $0.1348(3)$ & $0.7982(5)$ & $0.0430(16)$ \\
\hline $\mathrm{C} 20$ & $0.6151(4)$ & $0.1934(3)$ & $0.7807(5)$ & $0.0396(15)$ \\
\hline $\mathrm{C} 21$ & $0.5724(4)$ & $0.2145(3)$ & $0.6789(5)$ & $0.0334(14)$ \\
\hline N21 & $0.5315(3)$ & $0.1757(2)$ & $0.6002(4)$ & $0.0337(12)$ \\
\hline $\mathrm{C} 22$ & $0.5783(5)$ & $0.2715(3)$ & $0.6431(5)$ & $0.0413(15)$ \\
\hline $\mathrm{C} 23$ & $0.6290(5)$ & $0.3162(3)$ & $0.7083(5)$ & $0.0480(17)$ \\
\hline $\mathrm{C} 24$ & $0.6410(5)$ & $0.3657(3)$ & $0.6655(6)$ & $0.0545(19)$ \\
\hline $\mathrm{C} 25$ & $0.6051(5)$ & $0.3704(3)$ & $0.5590(6)$ & $0.0503(17)$ \\
\hline $\mathrm{C} 26$ & $0.5535(5)$ & $0.3241(3)$ & $0.4927(5)$ & $0.0416(15)$ \\
\hline $\mathrm{C} 27$ & $0.5399(4)$ & $0.2748(3)$ & $0.5340(5)$ & $0.0362(14)$ \\
\hline $\mathrm{O} 4$ & $0.1997(6)$ & $0.1627(4)$ & $0.4734(7)$ & $0.065(3)$ \\
\hline $\mathrm{C} 5$ & $0.1342(10)$ & $0.1160(6)$ & $0.4321(12)$ & $0.078(4)$ \\
\hline C6 & $0.1356(10)$ & $0.0686(8)$ & $0.5022(14)$ & $0.070(4)$ \\
\hline $\mathrm{F} 4$ & $0.0694(9)$ & $0.0294(6)$ & $0.4577(11)$ & $0.127(5)$ \\
\hline
\end{tabular}




$\begin{array}{lllll}\text { F5 } & 0.1266(9) & 0.0904(5) & 0.5794(10) & 0.107(4) \\ \text { F6 } & 0.2182(6) & 0.0413(4) & 0.5530(8) & 0.080(3) \\ \text { C1X } & 0.147(2) & 0.0314(11) & 0.651(2) & 0.113(8) \\ \text { C2X } & 0.135(4) & 0.0475(16) & 0.554(3) & 0.158(12) \\ \text { O3X } & 0.133(2) & 0.0111(13) & 0.4774(19) & 0.147(9) \\ \text { C4X } & 0.121(3) & 0.0215(15) & 0.377(3) & 0.159(11) \\ \text { C5X } & 0.111(3) & -0.0200(16) & 0.304(3) & 0.182(15)\end{array}$

Table S24 Bond Lengths for UM2783.

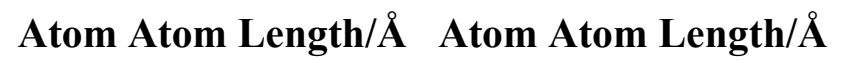

$\begin{array}{llllll}\text { Pt1 } & \text { C27 } & 1.967(7) & \text { C17 } & \text { N21 } & 1.341(8) \\ \text { Pt1 } & \text { O2 } & 1.995(4) & \text { C17 } & \text { C18 } & 1.382(8) \\ \text { Pt1 } & \text { N21 } & 2.013(5) & \text { C18 } & \text { C19 } & 1.396(9) \\ \text { Pt1 } & \text { N11 } & 2.038(5) & \text { C19 } & \text { C20 } & 1.389(10) \\ \text { Pt1 } & \text { O1 } & 2.068(4) & \text { C20 } & \text { C21 } & 1.396(9) \\ \text { Pt1 } & \text { O11 } & 2.202(4) & \text { C21 } & \text { N21 } & 1.357(8) \\ \text { O2 } & \text { C3 } & 1.407(7) & \text { C21 } & \text { C22 } & 1.461(9) \\ \text { C3 } & \text { C4 } & 1.487(10) & \text { C22 } & \text { C23 } & 1.378(10) \\ \text { C4 } & \text { F2 } & 1.323(9) & \text { C22 } & \text { C27 } & 1.416(8) \\ \text { C4 } & \text { F1 } & 1.334(9) & \text { C23 } & \text { C24 } & 1.391(11) \\ \text { C4 } & \text { F3 } & 1.338(8) & \text { C24 } & \text { C25 } & 1.390(10) \\ \text { O11 } & \text { S1 } & 1.484(4) & \text { C25 } & \text { C26 } & 1.416(10) \\ \text { O12 } & \text { S1 } & 1.444(4) & \text { C26 } & \text { C27 } & 1.386(9) \\ \text { C13 } & \text { C12 } & 1.387(9) & \text { O4 } & \text { C5 } & 1.435(11) \\ \text { C13 } & \text { C14 } & 1.393(8) & \text { C5 } & \text { C6 } & 1.52(2) \\ \text { S1 } & \text { O13 } & 1.433(5) & \text { C6 } & \text { F4 } & 1.315(19) \\ \text { S1 } & \text { C16 } & 1.832(6) & \text { C6 } & \text { F6 } & 1.336(18) \\ \text { N11 } & \text { C11 } & 1.338(7) & \text { C6 } & \text { F5 } & 1.347(18) \\ \text { N11 } & \text { C15 } & 1.372(7) & \text { C1X } & \text { C2X } & 1.41(4) \\ \text { C11 } & \text { C12 } & 1.376(9) & \text { C2X } & \text { O3X } & 1.42(3) \\ \text { C14 } & \text { C15 } & 1.378(8) & \text { O3X } & \text { C4X } & 1.43(3) \\ \text { C15 } & \text { C16 } & 1.519(8) & \text { C4X } & \text { C5X } & 1.42(4) \\ \text { C16 } & \text { C17 } & 1.501(8) & & & \end{array}$


Table S25. Bond Angles for UM2783.

\begin{tabular}{|c|c|c|c|c|c|c|c|}
\hline to & & Atom & Angle $/^{\circ}$ & Atom & Atom & Atom & Angle ${ }^{\circ}$ \\
\hline 27 & Pt1 & $\mathrm{O} 2$ & $96.4(2)$ & N11 & C15 & C16 & $118.7(5)$ \\
\hline 27 & Pt1 & $\mathrm{N} 21$ & $79.9(2)$ & $\mathrm{C} 14$ & $\mathrm{C} 15$ & C16 & $120.6(5)$ \\
\hline 2 & Pt1 & $\mathrm{N} 21$ & 173.3 & $\mathrm{C} 17$ & C16 & $\mathrm{C} 15$ & 5) \\
\hline 27 & Pt1 & N11 & $100.7(2)$ & $\mathrm{C} 17$ & C16 & S1 & $112.6(4)$ \\
\hline 2 & Pt1 & N11 & 89.91(17) & $\mathrm{C} 15$ & C16 & S1 & $108.8(4)$ \\
\hline 21 & Pt1 & N11 & 85.4 & $\mathrm{~N} 21$ & $\mathrm{C} 17$ & $\mathrm{C} 18$ & 11 \\
\hline 27 & Pt1 & O1 & $85.3(2)$ & N21 & $\mathrm{C} 17$ & C16 & $115.7(5)$ \\
\hline 2 & Pt1 & O1 & 92.96 & $\mathrm{C} 18$ & $\mathrm{C} 17$ & C16 & 6) \\
\hline 21 & Pt1 & $\mathrm{O} 1$ & $92.16(17)$ & $\mathrm{C} 17$ & $\mathrm{C} 18$ & C19 & $118.6(6)$ \\
\hline 11 & Pt1 & O1 & 173.0 & $\mathrm{C} 20$ & C19 & $\mathrm{C} 18$ & 6) \\
\hline 27 & Pt1 & O11 & $173.39(19)$ & C19 & $\mathrm{C} 20$ & $\mathrm{C} 21$ & $120.1(6)$ \\
\hline 2 & Pt1 & O11 & 87.42 & $\mathrm{~N} 21$ & $\mathrm{C} 21$ & $\mathrm{C} 20$ & $117.0(6)$ \\
\hline 21 & Pt1 & O11 & $96.87(19)$ & $\mathrm{N} 21$ & $\mathrm{C} 21$ & $\mathrm{C} 22$ & $112.9(5)$ \\
\hline 11 & Pt1 & 011 & 84.65 & $\mathrm{C} 20$ & $\mathrm{C} 21$ & $\mathrm{C} 22$ & $129.3(6)$ \\
\hline 1 & Pt1 & O11 & 89.0 & $\mathrm{C} 17$ & $\mathrm{~N} 21$ & $\mathrm{C} 21$ & (5) \\
\hline 63 & $\mathrm{O} 2$ & Pt1 & $117.2(4)$ & $\mathrm{C} 17$ & N21 & Pt1 & $120.9(4)$ \\
\hline 2 & $\mathrm{C} 3$ & $\mathrm{C} 4$ & 108 & $\mathrm{C} 21$ & $\mathrm{~N} 21$ & Pt1 & 4) \\
\hline 2 & $\mathrm{C} 4$ & $\mathrm{~F} 1$ & 106 & $\mathrm{C} 23$ & $\mathrm{C} 22$ & $\mathrm{C} 27$ & $3(7)$ \\
\hline 2 & $\mathrm{C} 4$ & F3 & 106. & $\mathrm{C} 23$ & $\mathrm{C} 22$ & $\mathrm{C} 21$ & (6) \\
\hline 1 & $\mathrm{C} 4$ & F3 & 106. & $\mathrm{C} 27$ & $\mathrm{C} 22$ & $\mathrm{C} 21$ & $113.6(6)$ \\
\hline 2 & $\mathrm{C} 4$ & $\mathrm{C} 3$ & 114 & $\mathrm{C} 22$ & $\mathrm{C} 23$ & $\mathrm{C} 24$ & (7) \\
\hline 1 & $\mathrm{C} 4$ & $\mathrm{C} 3$ & 112.6 & $\mathrm{C} 25$ & $\mathrm{C} 24$ & $\mathrm{C} 23$ & $121.4(7)$ \\
\hline 3 & $\mathrm{C} 4$ & $\mathrm{C} 3$ & 110 & $\mathrm{C} 24$ & $\mathrm{C} 25$ & $\mathrm{C} 26$ & 119.1(7) \\
\hline 1 & O11 & Pt1 & $118.9(2)$ & $\mathrm{C} 27$ & $\mathrm{C} 26$ & $\mathrm{C} 25$ & $120.2(6)$ \\
\hline 12 & $\mathrm{C} 13$ & $\mathrm{C} 14$ & $118.4(6)$ & $\mathrm{C} 26$ & $\mathrm{C} 27$ & $\mathrm{C} 22$ & $119.0(6)$ \\
\hline 13 & S1 & $\mathrm{O} 12$ & $116.1(3)$ & $\mathrm{C} 26$ & $\mathrm{C} 27$ & Pt1 & $126.9(5)$ \\
\hline 13 & $\mathrm{~S} 1$ & O11 & 111.2 & $\mathrm{C} 22$ & $\mathrm{C} 27$ & Pt1 & $113.8(5)$ \\
\hline 012 & S1 & $\mathrm{O} 11$ & $113.1(3)$ & $\mathrm{O} 4$ & $\mathrm{C} 5$ & C6 & $121.6(12)$ \\
\hline 13 & S1 & $\mathrm{C} 1$ & $105.6(3)$ & F4 & C6 & F6 & $107.2(14)$ \\
\hline 12 & S1 & $\mathrm{C} 16$ & $105.1(3)$ & F4 & C6 & F5 & $105.0(15)$ \\
\hline O11 & S1 & $\mathrm{C} 16$ & $104.5(3)$ & F6 & C6 & F5 & $103.7(14)$ \\
\hline C11 & N11 & $\mathrm{C} 15$ & $119.1(5)$ & F4 & C6 & $\mathrm{C} 5$ & $116.9(15)$ \\
\hline 11 & N11 & Pt1 & $123.6(4)$ & F6 & C6 & $\mathrm{C} 5$ & $112.3(13)$ \\
\hline 15 & N11 & Pt1 & $116.9(4)$ & F5 & $\mathrm{C} 6$ & $\mathrm{C} 5$ & $110.8(14)$ \\
\hline N11 & C11 & $\mathrm{C} 12$ & $122.3(6)$ & $\mathrm{C} 1 \mathrm{X}$ & $\mathrm{C} 2 \mathrm{X}$ & O3X & $127(3)$ \\
\hline 11 & $\mathrm{C} 12$ & $\mathrm{C} 13$ & $119.5(6)$ & $\mathrm{C} 2 \mathrm{X}$ & O3X & C4X & $133(4)$ \\
\hline
\end{tabular}


$\begin{array}{llllllll}\text { C15 } & \text { C14 } & \text { C13 } & 120.0(6) & \text { C5X } & \text { C4X } & \text { O3X } & 127(3)\end{array}$

N11 C15 C14 120.7(5) 


\section{References}

1. Liu, C.; Han, N.; Song, X.; Qiu, J. Eur. J. Org. Chem. 2010, 5548-5551.

2. Parr, R.G.; Yang, W. Density-functional Theory of Atoms and Molecules; Oxford University Press: Oxford, 1989.

3. Perdew, J.P.; Burke, K.; Ernzerhof, M. Phys. Rev. Lett. 1996, 77, 3865-8.

4. Jaguar, version 8.4, Schrödinger, LLC, New York, NY, 2014. 